\title{
AIDS ENTRE USUÁRIOS DE DROGAS INJETÁVEIS NA ÚLTIMA DÉCADA DO SÉCULO XX, NA REGIÃO METROPOLITANA DE SANTOS; ESTADO DE SÃO PAULO - BRASIL.
}

FÁBIO CALDAS DE MESQUITA

Tese apresentada junto à Faculdade de Saúde Pública da Universidade de São Paulo para obtenção do título de Doutor em Saúde Pública

Área de Concentração: Epidemiologia

Orientadora: Professora Doutora Cassia Maria Buchalla Co-orientador: Professor Doutor Eduardo Massad 
Dedico este trabalho a Ju Mesquita, Laurinha, Reca, Dr Mesquita, Dona Leda e aos usuários de drogas injetáveis.

"Astros, noites, tempestades, Rolai das imensidades, Varrei os mares tufão"

Castro Alves 


\section{Agradecimentos}

Nos manuais de redação de tese não estão anotadas as dificuldades relativas aos agradecimentos. Talvez porque este ponto alto da atividade profissional possa levar a uma introspecção dos autores; e ao raciocínio freqüente dos leitores, de que aquele futuro Doutor ou Mestre deve ter feito por merecer, por esforço próprio, "para chegar onde chegou". Posso afirmar que não me lembro de ter trabalhado sozinho em um só momento deste processo, e que ele não teria sido possível sem este esforço coletivo. De outro lado, a dificuldade maior deste momento é a de não cometer deslizes e erros. Desta forma, ao final destes agradecimentos, me sentirei mais humano, com a certeza de que errar é básico em nossa natureza.

Agradeço a Cassia Buchalla, luz no túnel em busca da renovação da Escola de Saúde Pública da USP, mais engajada e independente, em tempos de oficialismo. Amiga, parceira, estimuladora, presente e clara, dentre tantos outros predicados dos quais abusei. A orientadora que todo pós-graduando gostaria de ter.

Ao Professor Eduardo Massad, que é professor não só pelo título, mas pelo prazer que tem de pacientemente compartilhar seu saber, sua estrutura e sua experiência com pessoas do mais amplo espectro. Sua tolerância permitiu até que com sua britânica formação, não se incomodasse com meu "sandwich" na Califórnia. Decisões na vida, no curso, na escola e na tese, tiveram seu crucial apoio por mais de uma década.

Artur Reingold, professor de Saúde Pública da Universidade da Califórnia de Berkeley, fundamental no início de minhas atividades de pesquisa em 1991, e que em 1999 propiciou todas as condições para que este trabalho ganhasse forma durante meu "sandwich" naquela instituição. Pouca gente do Brasil contribuiu tanto quanto ele com a formação e desenvolvimento de pesquisadores brasileiros nas diversas áreas relacionadas à epidemia de AIDS.

Minhas parceiras de pesquisa de todos os tempos Regina Bueno e Giselda Lopes, inseparáveis amigas com quem sempre valeu a pena trabalhar. Muito do trabalho duro desta tese teria sido impossível sem a participação desta dupla em todas as fases.

Ilham Haddad, Daniela Piconez, Paula Jayme, Marta Sanches e Rita Haieck, completam o time de pessoas que compartilharam momentos diferentes dos protocolos de pesquisa em nossa equipe de pesquisadores. Daniela merece menção especial pela paciência de me aturar durante o último protocolo, particularmente depois de minha viagem para os Estados Unidos.

Alexandre de Souza Júnior, Emerson Suriani Silva, Juliana Romano Flores, Laura Veiga dos Santos, Renata Cristina de Souza, Renato da Costa, Rita de Cássia Haiek Kenchian, Rosana Cravo Leite, Simone Pisan Soares e Simone Tenório dos Santos pela destacada contribuição como entrevistadores do Estudo III.

Dr Edmir Boturão Neto, Dr. Raymundo Soares de Azevedo Neto, Dr. Milton Arthur Ruiz e suas equipes de trabalho, pela contribuição de retaguarda laboratorial nos três Estudos. Às flebotomistas que durante estes dez anos estiveram com a gente onde foi necessário para colher sangue.

David Capistrano Filho (in memorium) e Telma de Souza, ao lado dos quais, entre tapas e beijos, dei alguns dos primeiros passos deste estudo e de minha carreira. Eduardo Palmieri e Márcio França, gente de São Vicente que segurou todas as barras e contribuiu sobremaneira para o desenvolvimento deste projeto de vida em sua fase 
decisiva. Ilham Haddad, pela segurança que tive em poder contar com ela como Assistente de Coordenação de DST/AIDS de São Vicente enquanto estudava e aprontava a base para este trabalho. Em nome dela, agradeço a todos os técnicos e funcionários do Programa Municipal de DST/AIDS de São Vicente, que direta ou indiretamente, muito contribuíram para este trabalho.

Eliana (IEPAS), Elaine (SESAU) e Juanita, Dianne e Susan (U C Berkeley), que garantiram o apoio que qualquer um precisa para trabalhar em paz.

Silvana C Almeida e Marcos Miranda pelo suporte moral e financeiro.

EMBRABIO, Empresa Brasileira de Biotecnologia, que desde o primeiro Estudo contribuiu com o desenvolvimento da pesquisa científica em nosso meio.

Maria Amélia Veras e Carol Marchand foram figuras chaves para garantir moradia, algo básico para quem precisa dirigir energia para o trabalho. Maria Amélia foi também companheira de Departamento de Epidemiologia da Escola de Saúde Pública de Berkeley, de momentos de alegria e de lamentações típicas do exílio. Em nome dela, agradeço a convivência com tantos brasileiros e estrangeiros de boa alma que compartilharam momentos críticos com o autor.

Tatico, ou Dr. Heráclito Barbosa de Carvalho, pelo seu imprescindível trabalho de colocar junto a informação de três Estudos (cada um a sua vez), organizando os Bancos de Dados e contribuindo destacadamente na fase de análises dos Estudos I e II e no fechamento deste trabalho.

Alex Kral, Doutor em Epidemiologia, militante da ADS entre UDIs e devotado estatístico instalado na Universidade da Califórnia de San Francisco, com o qual compartilhei as angústias e alegrias das análises estatísticas aqui apresentadas.

Chico Inácio Bastos, Tarcísio Andrade e Sérgio Seibel, pela contribuição de agora e de sempre na parceria e na fonte de inspiração nacional.

Alex Wodak (Austrália), Pat O’Hare (Itália) e David Purchase (USA) pelo mesmo motivo anterior, fora do Brasil. Nick Crofts (Austrália), por sua especial contribuição nas informações de hepatites, mas não só nisto. Aaron Peak (Tailândia) pelo modelo desbravador em países em desenvolvimento. Andrew Ball (OMS/Suíça) que manteve o quanto pode a chama do Estudo Multicêntrico.

Pedro Chequer, pelo apoio dado a pesquisa sempre que foi necessário. Em nome dele agradeço o suporte de todos os técnicos da Coordenação Nacional de DST/AIDS do Ministério da Saúde do Brasil de sua época.

Artur Kalichman, de quem além de contar com seu grande apoio pessoal, usei uma expressão durante todos os anos do doutorado: "No final tudo vai dar certo; e se ainda não deu certo, é porque não chegou no final”. Em nome do Artur, agradeço a contribuição de todos os técnicos e funcionários do Programa de DST/AIDS do Estado de São Paulo.

Paulo Roberto Teixeira com quem tive enorme prazer de compartilhar etapas diferentes de trabalho, nos antecedentes por São Paulo, em suas atividades na UNAIDS no Cone Sul da América do Sul e finalmente na Coordenação Nacional de AIDS. Em nome dele agradeço com particular atenção aos colegas na Coordenação Nacional de DST/AIDS do dia a dia do segundo semestre do ano 2000.

Aos membros de minha Banca Examinadora (Dra Cassia Maria Buchalla, Dra Maria do Rosário Dias de Oliveira Latorre, Dr. Francisco Inácio Bastos; Dr. Tarcísio Andrade e Dr. Euclides Ayres de Castilho) que pacientemente leram e muito contribuíram para aprimorar o formato final deste trabalho. 
Particular gratidão a professora Maria Regina Alves Cardoso pela iluminação que proporcionou durante a minha qualificação.

Laura Mesquita, que com seus e-mails bem humorados e carinhosos me manteve grudado no computador com outros propósitos e me ensinou a viver longe do país que a gente gosta. Juliana Mesquita que compartilhou momentos de altos e baixos com a paixão e entusiasmo de sempre e não deixou a minha peteca cair. Reca, que além da pesquisadora associada, foi o ombro e o colo que me mantiveram firme.

Neff e Leda, que me incentivaram desde a vida intra-uterina atingindo o ápice neste último período. Waniel e Fernando, meus irmãos que completaram este apoio familiar.

Juliana Nasciutti por sua contribuição na revisão (não final) da língua mãe. Roberto Simas que formatou e revisou a versão final deste texto, contribuindo em muito para torna-lo mais inteligível.

Ao Casseta\&Planeta, Silvana C Almeida, Suely Takasus e Maria Fernanda Frutuoso, por manterem meu humor elevado, estímulo fundamental para manter o raciocínio a altura.

Ao Lance na Internet e os músicos Caetano Veloso, Chico Buarque, Chitãozinho e Xororó, Gabriel o Pensador, e outros, que me fizeram relaxar quando era necessário (e como foi!).

Nomináveis e anônimos que não vão me perdoar por tê-los esquecido no delicado momento de agradecer, minha eterna gratidão. 


\section{Resumo:}

Antecedentes: A Região Metropolitana de Santos (RMS), SP, é conhecida como sendo uma das áreas com o maior número de casos de AIDS proporcionais à população do Brasil. O principal objetivo deste trabalho é estudar a tendência da epidemia de HIV e seus determinantes, entre os usuários de drogas injetáveis (UDIs), durante a década de 90, na região.

Métodos: Durante 1991/1992 (Estudo I; N= 220), 1994/1996 (Estudo II; N= 140), e 1999 (Estudo III; $N=108$ ) foram conduzidos três estudos transversais. Todos os participantes foram entrevistados e testados para HIV, hepatites $\mathrm{B}$ e $\mathrm{C}$.

Resultados: A amostra, de 468 UDIs, tinha $70 \%$ de homens, $87 \%$ abaixo de 40 anos de idade. $84 \%$ com menos de 9 anos de educação formal. As taxas de soroprevalência para HIV foram de $63 \%, 65 \%$ e $42 \%$ nos respectivos estudos $(\mathrm{p}<0.001)$. O uso de crack cresceu de $11 \%$ para $60 \%$ e $67 \%$ nos respectivos estudos $(\mathrm{p}<0.001)$. A freqüência de uso injetável ( $>5$ vezes por dia) diminuiu de $42 \%$ no Estudo I, para $30 \%$ no Estudo II e para $15 \%$ no Estudo III $(\mathrm{p}<0.001)$. Não houve alteração significativa do padrão de sexo seguro na população.

Conclusões: A taxa de prevalência de HIV decresceu entre o $2^{\circ}$ e o $3^{\circ}$ estudos, assim como a freqüência de uso de drogas injetável decresceu e o uso de crack aumentou. As mudanças nos padrões de consumo provavelmente afetaram mais a epidemia de HIV do que as modestas intervenções que a saúde pública pôde fazer nos últimos 10 anos. 
Summary:

Background: Santos Metropolitan Region (SMR), State of Sao Paulo, historically is well known as having one of the areas with the largest number of AIDS cases in Brazil, especially among injection drug users (IDUs). The main objective of this study is to analyze the trends of the HIV epidemic and it's determinants, among injecting drug users, in the Santos Metropolitan Region in the 1990's.

Methods: During 1991/1992 (Wave 1; N=220), 1994/1996 (Wave 2; N=140), and 1999 (Wave 3; $\mathrm{N}=108$ ) we conducted three cross sectional studies of IDUs. All participants were interviewed and tested for antibodies for HIV, Hepatitis B and C.

Findings: The overall sample of 468 injecting drug users were $70 \%$ male, $87 \%$ under 40 years old. $84 \%$ had less than 9 years of education. HIV seroprevalence was $63 \%$ in wave $1,65 \%$ in wave 2 , and $42 \%$ in wave 3 $(\mathrm{p}<0.001)$. Crack cocaine use increased from $11 \%$ to $60 \%$ and $67 \%$ respectively $(\mathrm{p}<0.001)$. The prevalence of frequent injection ( $>5$ per day) decreased from $42 \%$ in wave 1 to $30 \%$ in wave 2 and $15 \%$ in wave 3 $(\mathrm{p}<0.001)$. There were no significant change in safe sex patterns in the IDU population during this study.

Interpretation: HIV prevalence decreased from the $2^{\text {nd }}$ to the $3^{\text {rd }}$ studies, as frequency of injection decreased and crack cocaine increased. In Santos Metropolitan Area, Brazil, patterns of drug use have been affecting the HIV epidemic maybe more than scant public health intervention in the last ten years. 


\section{Índice}

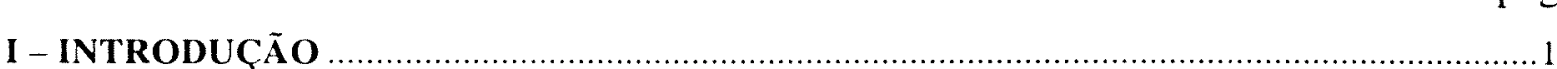

I.1 - Contextualizando o Fenômeno de Drogas no Brasil e no Mundo........................................5

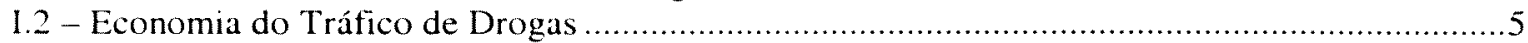

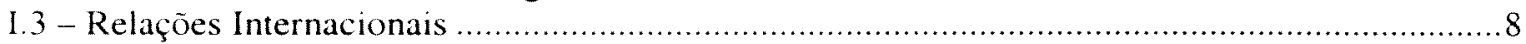

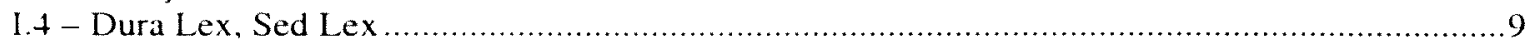

1.5 - Políticas Públicas de Drogas, incluindo Políticas Públicas de Saúde para Drogas .................11

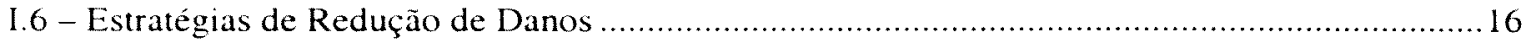

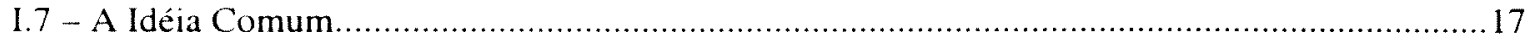

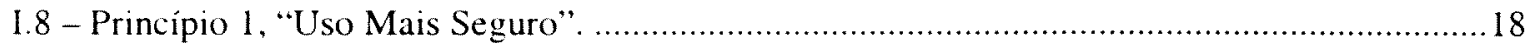

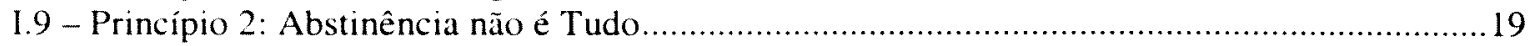

1.10 - Princípio 3: Usuário de Drogas, Cidadão e Agente de Saúde ...................................21

1.11 - O usuário de drogas, injetáveis e de outras drogas ...............................................22

I.12 - Breve Histórico da Redução de Danos no Brasil ....................................................25

I.13 - Revendo a Bibliografia Brasileira sobre uso de drogas do Final do Século XX.................27

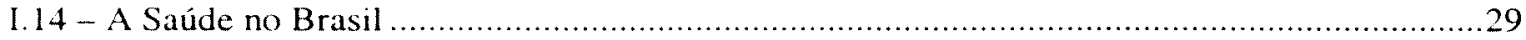

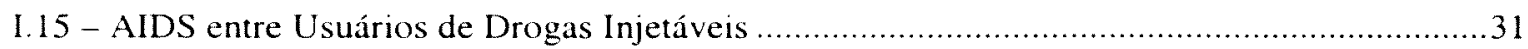

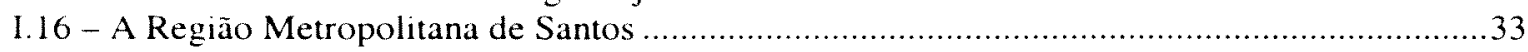

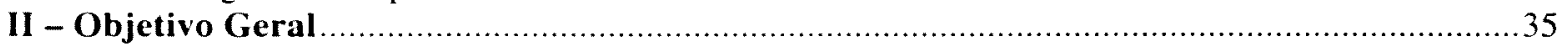

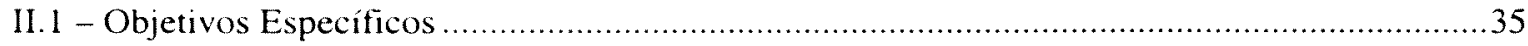

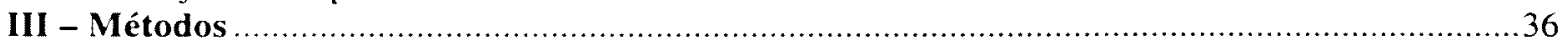

III.1 - Informações sobre os Estudos Transversais que compõem este trabalho ...........................36

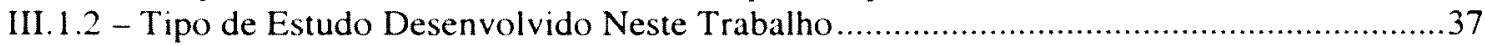

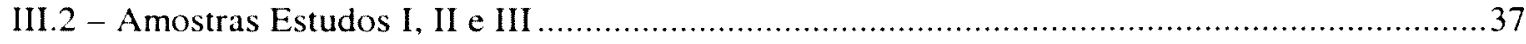

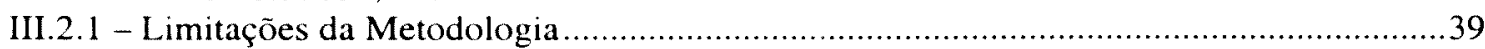

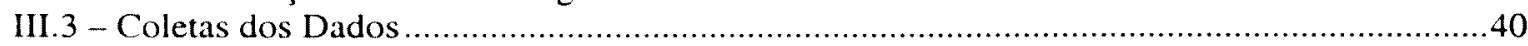

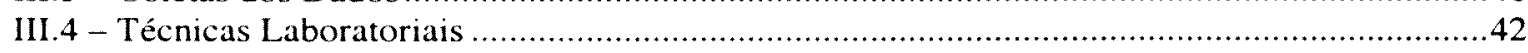

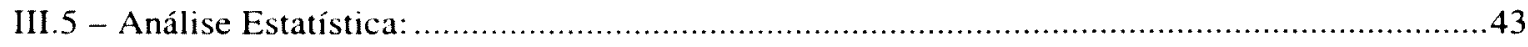

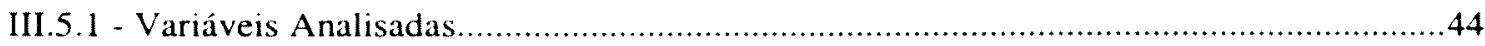

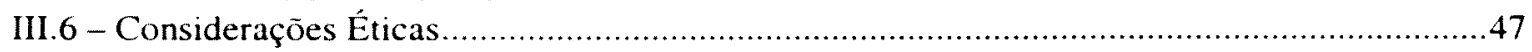

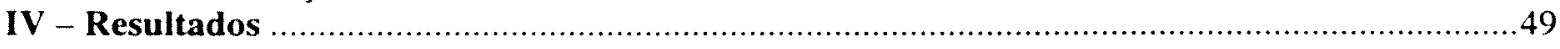

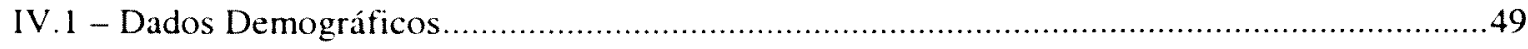

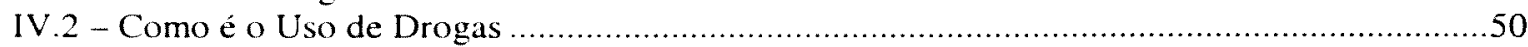

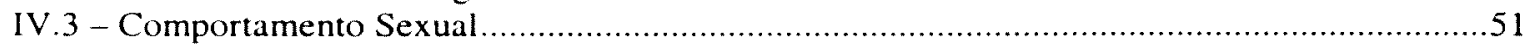

IV.4 - Mudanças de Comportamento Influenciadas pelo Conhecimento de HIV/AIDS .................52

IV.5 - Prevalência do HIV e de outras doeņ̧as ......................................................5

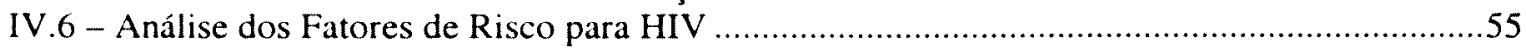

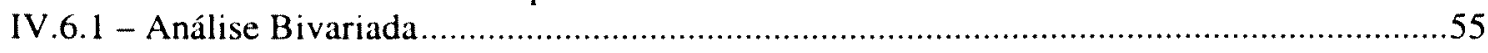

IV.6.2 - Análise Multivariada (Regressão Logística) .....................................................56

IV.6.3 - Outros Achados Relevantes para a Saúde da População Alvo...................................57

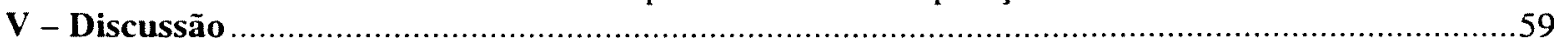

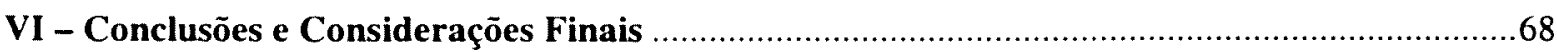

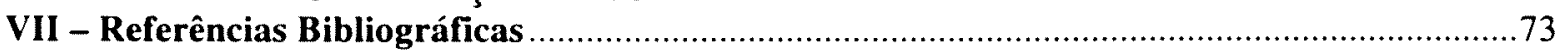

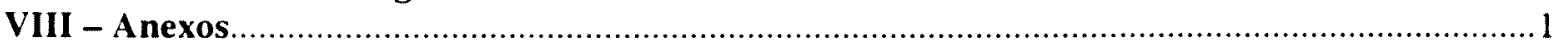

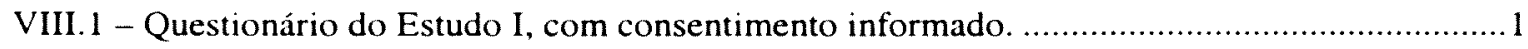

VIII.2 - Questionário do Estudo II, com consentimento informado. ..................................2

VIII.3 - Questionário do Estudo III, com consentimento informado.......................................... 3 


\section{Fontes de Financiamento:}

\section{Estudo I:}

Programa Nacional de DST/AIDS do Ministério da Saúde do Brasil

Organização Pan Americana da Saúde (escritório de Brasília)

Secretaria Municipal de Higiene e Saúde de Santos

Hospital Guilherme Álvaro

Fundação de Apoio à Pesquisa do Estado de São Paulo (FAPESP)

Laboratório de Investigação Médica - LIM 01 - Hospital das Clínicas da Faculdade de Medicina da Universidade de São Paulo

Universidade da Califórnia Berkeley (Fogarty International AIDS Training)

Empresa Brasileira de Biotecnologia (EMBRABIO)

\section{Estudo II:}

Programa Nacional de DST/AIDS do Ministério da Saúde do Brasil

Secretaria Municipal de Higiene e Saúde de Santos

Laboratório de Investigação Médica - LIM 01 - Hospital das Clínicas da Faculdade de Medicina da Universidade de São Paulo

Empresa Brasileira de Biotecnologia (EMBRABIO)

\section{Estudo III:}

Programa Nacional de DST/AIDS do Ministério da Saúde do Brasil

Programa Estadual de DST/AIDS do Estado de São Paulo

Secretaria Municipal da Saúde de São Vicente

Laboratório de Investigação Médica - LIM 01 - Hospital das Clínicas da Faculdade de Medicina da Universidade de São Paulo

Miranda Advocacia

Universidade da Califórnia Berkeley (Fogarty International AIDS Training)

Empresa Brasileira de Biotecnologia (EMBRABIO) 


\section{Glossário}

ABORDA - Associação Brasileira de Redutores de Danos

AIDS - Síndrome da Imunodeficiência Adquirida

CDC - Centers for Disease Control and Prevention

CN DST/AIDS - Coordenação Nacional de Doenças Sexualmente Transmissíveis e AIDS do Ministério da Saúde do Brasil

CONEN - Conselho Estadual de Entorpecentes

CONFEN - Conselho Federal de Entorpecentes

CVE - Centro de Vigilância Epidemiológica

DARE - Drug Abuse Resistance Education

DEA - Drug Enforcement Agency - Agencia de Drogas Norte Americana

DST - Doenças Sexualmente Transmissíveis

Dura Lex, Sed Lex - A Lei é dura, mas é a Lei

ELISA - teste de laboratório "Enzyme Linked Imunosorbent Assay"

Ex-UDIs - Ex-usuário de drogas injetáveis

HBV - Vírus da hepatite B

HCV - Vírus da hepatite C

HIV - Vírus da Imunodeficiência Humana

IBGE - Instituto Brasileiro de Geografia e Estatística

IBOPE - Instituto Brasileiro de Opinião Pública e Estatística

IEPAS - Instituto de Estudos e Pesquisas em AIDS de Santos

NIDA - National Institute on Drug Abuse _ Instituto Nacional de Abuso de Drogas dos estados Unidos da América do Norte

NUDIs - Nunca Usuário de Drogas Injetáveis

OMS - Organização Mundial da Saúde

ONG - Organização Não Governamental

PSDB - Partido da Social Democracia Brasileira

PT - Partido dos Trabalhadores

PE DST/AIDS SP - Programa de DST/AIDS do Governo do Estado de São Paulo PIB - Produto Interno Bruto

PROERD - Programa de Resistência às Drogas

REDUC - Rede Brasileira de Redução de Danos 
RELARD - Rede Latino Americana de Redução de Danos

RMS - Região Metropolitana de Santos

SENAD - Secretaria Nacional Anti-Drogas do Governo Brasileiro

UDIs - Usuários de Drogas Injetáveis

UNAIDS - United Nations Global AIDS Program - Programa de AIDS das Nações Unidas

UNDCP - United Nations International Drug Control Program - Programa de Drogas das Nações Unidas

USA - United States of America - Estados Unidos da América do Norte

WHO - World Health Organization ou Organização Mundial da Saúde. 


\section{I - INTRODUÇ̃̃̃}

O mundo percebeu cedo a ligação entre a transmissão de HIV e o uso de drogas injetáveis. Epidemia com esta característica predominante se instalou inicialmente na Europa, e em algumas regiões da América do Norte, e tornou-se rapidamente um fenômeno mundial (1). A Organização Mundial da Saúde registrou a presença do uso de drogas injetáveis em mais de 126 países. Destes, 98 haviam notificado casos de AIDS cuja forma de transmissão foi considerada o uso de drogas injetáveis (2) '. Questões sociais, políticas públicas de drogas e de saúde, e até mesmo interesses econômicos, já mostraram sua vinculação com mudanças no padrão de consumo destas substâncias e uma consequiente série de danos à saúde dos usuários, seus parceiros sexuais e filhos (3-5). Este conceito mais genérico que considera vulnerabilidade coletiva como aquelas ações extra indivíduo que influenciam a epidemia de AIDS, foi muito bem definido por Jonathan Mann (19471998) e colaboradores (6). No Brasil Ayres e colaboradores foram os que mais se debruçaram sobre o mesmo tema. Na opinião destes autores embora não haja uma definição final para o conceito de vulnerabilidade ao HIV/AIDS, o mesmo "se expressa na busca de reposta aos diferentes graus de suscetibilidade de indivíduos e coletividades à infecção, adoecimento ou morte pelo HIV, segundo a particularidade de sua situação quanto ao conjunto integrado dos aspectos sociais, programáticos e individuais que os põem em relação ao problema e com os recursos para seu enfrentamento" (7)

Carlini e colaboradores em estudo coordenado pela Organização Mundial da Saúde sobre a cocaína publicado em 1995, descrevem detalhes interessantes da história do uso de cocaína no Brasil. Este uso, tem suas primeiras menções na imprensa leiga brasileira por volta de 1910. Alarmistas, as informações de jornais como O Estado de São Paulo e o Rio Jornal neste período dão conta de um crescente uso de cocaína na população geral. Esta informação no entanto é contradita com outras duas fornecidas pelo mesmo autor no referido texto: a) entre 1925 e 1931 , apenas 22 apreensões de cocaína foram realizadas, sendo a maior delas de 230

\footnotetext{
'Durante o "Third Anual Meeting (5-7 julho de 2000): 2000 Global Research Network Meeting on HIV Prevention in Drug-Using Populations" em Durban, África do Sul, este dado foi atualizado na apresentação oral de Richard Needle (NIDAVUSA) para o final de 1999: 134 países reportando uso de drogas injetáveis, dos quais 114 com casos de HIV entre usuários de drogas injetáveis.
} 
gramas; b) entre 1921 e 1924, serviços especializados em tratamento de dependência de drogas, internaram 16 casos relacionados à cocaína(8). Ainda que apontado no início do século passado, o uso mais intenso da cocaína no entanto, foi denotado nas últimas 2 décadas do século $\mathrm{XX}$, como conseqüência da política externa norte americana conhecida como "Guerra Contra as Drogas". A ajuda militar e o recrudescimento de uma política repressiva impostos por esta "Guerra" aos países andinos produtores de coca, fizeram com que o tráfico de drogas buscasse rotas alternativas de distribuição para os mercados que significavam maior lucro, como o europeu e o da América do Norte. O Brasil, como alguns de seus vizinhos do Mercosul, passaram a integrar estas novas rotas. Como desdobramento desta estratégia comercial, era necessário ainda estabelecer um mercado consumidor importante e frações de organizações criminosas capazes de manter e fazer crescer os negócios relacionados $(9,10)$. Para além das organizações criminosas, outras tantas organizações têm se beneficiado do crescimento do consumo de drogas (11). Este quadro comercial, somado a situação de desemprego e falta de oportunidades crescentes para muitos brasileiros, foram determinantes para a expansão de uma rede de distribuição e consumo sem precedentes no país. Nos últimos 20 anos, o país viveu um aumento significativo do consumo de cocaína em forma de pó (aspirada ou injetada) e de pedras de crack (fumado ou injetado). Relatos recentes confirmados em grande parte pelos estudos que aqui serão analisados, dão conta de uma série de outras substâncias consumidas em nosso meio em menor escala, dentre as quais a heroína (12).

No Brasil, já no início da epidemia de HIV/AIDS, ficou evidente o papel dos usuários de drogas injetáveis em seu curso. Em 1989, houve uma primeira proposta de intervenção que pudesse alterar esta trajetória: a proposta da Coordenação Municipal de DST/AIDS de Santos de distribuir seringas estéreis aos usuários de drogas injetáveis(13), tal qual como vinha sendo feito em outros países como na Holanda desde 1982 e na Austrália desde 1985. Começava aí uma batalha política e jurídica que envolveu autoridades de Saúde Pública, militantes, redutores de danos e outros setores favoráveis de um lado; $\mathrm{e}$ as autoridades responsáveis pela interpretação e aplicação das Leis em vigor no país (tais como Promotores e Delegados de Polícia) de outro lado, com numerosas implicações para o desenrolar 
da epidemia (14). Este debate de como a sociedade brasileira controlaria a epidemia de HIV/AIDS entre UDIs, que se desenvolveu nas circunstâncias já descritas, acabou tendo sérias conseqüências.

Com uma ação específica retardada e de pequeno espectro; aplicada às condições de uma estrutura de saúde precária no país; em um meio social desfavorável à maioria da população, a epidemia de HIV entre UDIs, seguiu um curso que pôde ser avaliado durante toda a década de 90 . O presente trabalho trata de três dos Estudos que auxiliam a avaliação do que ocorreu neste período em termos de tendência da transmissão do HIV entre UDIs e seus determinantes, na Região Metropolitana de Santos (RMS), palco da luta previamente mencionada. Estes estudos epidemiológicos foram contextualizados para este trabalho dentro de uma abordagem mais ampla, considerando para além dos números que refletem a vulnerabilidade individual, as questões sociais, econômicas e de políticas públicas dentre outras, que refletem a vulnerabilidade coletiva.

Um primeiro estudo, o Estudo Multicêntrico da Organização Mundial da Saúde (OMS) de HIV entre usuários de drogas injetáveis, ocorreu em 1991 e 1992, e analisou os fatores de risco e as taxas de soroprevalência para o HIV (15). A Região Metropolitana de Santos foi envolvida nesta fase do estudo pela importância de então que os UDIs tiveram na epidemia de HIV/AIDS. Os dados da RMS foram utilizados pela OMS para serem comparados com outras 12 cidades do mundo, no maior Estudo já realizado em tal temática até o final da década de 90. Com a RMS virgem de intervenção neste momento, o Estudo aponta uma espécie de parâmetro inicial de análise. Aqui também foi possível medir as taxas de infecção de hepatites B e C na região (16).

O segundo estudo, o Projeto Brasil, foi o maior estudo de soroprevalência de HIV e comportamento entre UDIs realizado no País até hoje. Foram realizadas 668 entrevistas com usuários de drogas injetáveis, em cinco centros de pesquisa, em quatro regiões distintas no Brasil(17). Desta vez, o Instituto de Estudos e Pesquisas em AIDS de Santos coordenou nacionalmente o Estudo, que entrevistou usuários de drogas injetáveis entre os anos de 1994 e 1996. Na cidade de Santos tínhamos em curso desde 1993, um trabalho de redutores de danos ("outreach workers") que, com base na proposta de educação de pares, levava entre outros instrumentos de 
prevenção, hipoclorito de sódio para a desinfecção de seringas entre a população alvo deste Estudo (18). Foram ainda realizados exames sorológicos de hepatites $\mathrm{B}$ e C nos entrevistados.

Finalmente em 1999, como parte da fase II do Estudo Multicêntrico da Organização Mundial da Saúde (OMS) de HIV entre usuários de drogas injetáveis, novamente se avaliaram as taxas de soroprevalência para HIV, hepatites $\mathrm{B}$ e $\mathrm{C}$ e os fatores de risco remanescentes na Região Metropolitana de Santos (19). Este estudo foi mais amplo em um aspecto, que não diminui sua comparabilidade com os anteriores: entrevistou usuários de drogas injetáveis; ex-usuários de drogas injetáveis e usuários de drogas que, potencialmente, poderão vir a ser injetáveis, dando uma noção importante de padrões de uso que influenciam a epidemia de HIV e AIDS em nosso meio.

A Região Metropolitana de Santos é conhecida com uma das regiões de maior incidência de casos de AIDS proporcionais à população do Brasil, e com um acentuado componente de uso de drogas injetáveis na história da epidemia regional. Um pouco do que ocorre na Região Metropolitana de Santos, pode ser visto como uma tendência da epidemia no Estado de São Paulo que detém $66 \%$ dos casos de AIDS por uso de drogas injetáveis do Brasil e $47 \%$ de todos os casos de AIDS do país (20). Este padrão da epidemia em São Paulo, tem portanto, enorme influência na tendência da epidemia no Brasil.

Este trabalho, composto das informações acumuladas por uma década, e de extensa revisão bibliográfica, analisa a trajetória da epidemia de HIV entre usuários de drogas injetáveis na Região Metropolitana da Baixada Santista no final do século XX. Marcada nos seus primeiros 15 anos pelo uso de drogas injetáveis, a epidemia de HIV sofre grande impacto da mudança de padrões de consumo de drogas, não necessariamente motivados por ações de Saúde Pública, como veremos a seguir. 


\section{I.1 - Contextualizando o Fenômeno de Drogas no Brasil e no Mundo}

Há muitos aspectos a analisar em fenômenos com características e implicações multilaterais como o das drogas. Vamos nos deter principalmente nos aspectos econômicos, de relações internacionais, jurídicos e de políticas públicas de drogas e de saúde. Esta decisão, deve-se ao fato de que estes aspectos estão mais diretamente relacionados com as conseqüências para a saúde da população alvo em estudo, bem como ao fato de que a droga é vista neste trabalho em sua perspectiva de saúde pública.

\section{I.2 - Economia do Tráfico de Drogas}

A Organização das Nações Unidas através de seu Programa Internacional de Controle de Drogas (UNDCP), estima que o comércio de drogas ilícitas movimenta cerca de $8 \%$ de todo o comércio mundial. Isto corresponde a cerca de 500 bilhões de dólares ao ano(21). Um paralelo econômico com o Produto Interno Bruto (PIB) da África Negra, dá a dimensão desta cifra. Estima-se que o PIB anual produzido por 600 milhões de Africanos seja o equivalente a 250 bilhões de dólares (22). A soma extraordinária de 500 bilhões seria suficiente para que nos contentássemos com a simplista opinião de que os traficantes de drogas têm lucros fabulosos oriundos deste comércio ilícito. Não obstante o fato de esta afirmação sobre os lucros dos traficantes ser verdadeira, isto não explica o conjunto da implicação econômica das drogas ilícitas em um mundo globalizado.

Neste quadro, não se deve desconsiderar inclusive os empregos gerados pelo tráfico de drogas, que com uma hierarquia militar, envolve milhares de pessoas geralmente marginais ao mercado formal de trabalho, já tão reduzido na maioria dos países e em particular no Brasil. Este "mercado de trabalho" embora não computado na economia informal pelo Instituto Brasileiro de Geografia e Estatística (IBGE), sabe-se ser importantíssimo na manutenção de níveis de subsistência e tolerabilidade em um país com economia conturbada como o Brasil. Mas para além do que acontece diretamente relacionado ao tráfico de drogas, flui uma enormidade de outros interesses relevantes para a economia. 
Senão vejamos: este volume de dinheiro, bastante expressivo, circula pelos mercados financeiros de maneira pouco discreta dado o seu montante. Portanto, instituições financeiras de diversos países têm controle, informação e auferem lucros desta circulação. Estima-se que o volume de dinheiro que originou-se no mercado de drogas e passou para a economia formal nos últimos 15 anos foi da ordem de dois trilhões de dólares. Quantia comparável à divida externa de todos os países em desenvolvimento, somados à divida externa dos países do Leste Europeu (22). Aqui novamente a globalização da economia e a informatização que faz da circulação de recursos virtuais uma tarefa trivial, são condicionantes básicos para que haja a integração do ilegal com o legal.

A pesquisadora do Departamento de Geografia da Universidade Federal do Rio de Janeiro (UFRJ), Lia Osório, vai mais longe:

"A simbiose que assistimos hoje entre as organizações que exploram o comércio de drogas ilícitas e o sistema bancário e financeiro internacional pode ser considerada não só como a questão mais importante entre todas as que caracterizam a economia da droga, mas também como a dimensăo sombria da própria evolução do mercado internacional de dinheiro e de divisas, hoje administrado por um sistema bancário e financeiro globalizado" (11).

Outro aspecto relevante é o das dificuldades econômicas de cada país em particular. Podemos iniciar pelo exemplo da economia dos Estados Unidos da América do Norte. Uma Comissão Parlamentar de Inquérito (CPI) que o Congresso norte americano organizou sobre o tráfico de drogas no inicio da década de 90 , chegou a numerosas conclusões relevantes. Dentre elas, que os lucros anuais do mercado de cocaína que permaneciam nos Estados Unidos eram da ordem de 26 bilhões de dólares; no caso da maconha chegava a 10 bilhões de dólares; sobre a heroína, não foi possível precisar uma quantia, embora se saiba que ela é bastante alta. Nas conclusões da CPI propôs-se intensificar o controle sobre a circulação de capitais. De nada adiantou a análise e a proposta, em uma economia que tinha à época uma dívida pública de 4,5 trilhões de dólares e que não pôde prescindir desta considerável fonte de circulação de divisas (22).

$\mathrm{Na}$ América Latina, economias como as da Bolívia e da Colômbia estão francamente ligadas aos dividendos do tráfico de drogas. Não obstante o fato de que 
dos lucros da produção de coca, uma quantidade pequena de recursos fique no próprio país de origem, recentes estimativas indicam que a Colômbia repatria cerca de 7 bilhões de dólares anuais referentes aos lucros do comercio ilícito de drogas. Apenas para se ter uma idéia do significado desta quantia, em 1993 o total de entradas na balança comercial Colombiana referente às exportações foi de 7,6 bilhões de dólares (23). Na Bolívia, a estimativa é que de todo o comércio exterior no mesmo ano de 1993, 98\% estava relacionado à "exportação" referente ao mercado de $\operatorname{coca}(24)$

Outro aspecto comercial relevante que mistura o legal e o ilegal, é o do comércio de armas. Este comércio, estimado em bilhões de dólares, também lucra com o tráfico de drogas em duplo sentido. Seja no controle do comerciante (armas a serviço do tráfico de drogas); seja no controle das pessoas da Lei (armas a serviço de quem tem missão institucional de combater o tráfico de drogas).

Para além das armas, há que se considerar os gastos estatais, a partir dos impostos pagos pelos cidadãos, para manter uma política bélica anti-drogas, assunto que será aprofundado no próximo tópico deste trabalho, mas que não podemos deixar de considerar sob o ponto de vista da economia. São milhares de empregos de policiais e delegacias especializadas (de diferentes níveis - estaduais, federais); treinamento de pessoal; equipamentos de investigação; gastos com sistema prisional; gastos com especialistas; e inúmeros outros que a "indústria" das drogas ilícitas cria e sustenta.

Ainda poderíamos considerar que as drogas mobilizam recursos utilizados em pesquisas, outras atividades acadêmicas de ensino e extensão, seminários e eventos afins, publicações de toda natureza, enfim um "negócio" com muitas interfaces.

Assim, existem uma série de atividades que não são comandadas diretamente por traficantes, mas que se beneficiam da ilegalidade das drogas.

A complexidade econômica do fenômeno drogas, tem como veremos a seguir, destacada relevância para a transmissão do HIV e outras consequiências à saúde da população. 


\section{I.3 - Relações Internacionais}

"Em tempos de guerra, entre os primeiros mortos e feridos, está a verdade" Boake Carter

O mundo, na década de 90, passou de uma fase de bipolaridade da guerra fria (característica do pós II Guerra Mundial até o fim da União Soviética em dezembro de 1991), para a consolidação de uma enorme hegemonia norte americana, sob o ponto de vista econômico e militar. Na questão da abordagem do fenômeno drogas, os norte-americanos têm também uma estratégia própria que se originou em um discurso do ex-presidente Richard Nixon, de 1971, declarando as drogas como "o inimigo público número 1". Anos mais tarde, em setembro de 1989, o ex-presidente George Bush denominaria esta política de "Guerra Contra as Drogas".

Alguns autores, consideram que a estratégia desencadeada por Nixon e seguida até os dias atuais, veio como uma necessidade de substituir a ameaça externa do comunismo, pela ameaça externa do tráfico internacional de drogas (25). Esta forma de ver a questão drogas, manteria a mobilização ideológica necessária ao funcionamento de uma sociedade competitiva como a norte americana, pós Guerra Fria.

Se analisarmos apenas o período da chamada "Guerra Contra as Drogas", verificaremos que não se obteve sucesso no tratamento bélico dessa questão tão abrangente. Dos 9 objetivos da "Guerra Contra as Drogas" propostos pelo expresidente Bush em 1989, 7 fracassaram nestes 10 últimos anos (26).

As cifras são grandiosas e começam com os gastos orçamentários na questão em foco. De um orçamento original de 7,9 bilhões de dólares em 1989, nos deparamos com uma proposta orçamentária do ex-presidente Bill Clinton para o ano 2000 de 17,8 bilhões de dólares. Estes recursos estão divididos em 66\% para repressão e 33\% para outros itens (tratamento, prevenção e pesquisa). No item repressão, estão incluídos recursos para a chamada "ajuda externa" como por exemplo a proposta de intervenção militar na Colômbia, da ordem de 1,3 bilhões de dólares (27).

Estes recursos de "ajuda externa", foram os recursos empregados em treinamento de forças militares, compra de equipamentos, dentre outros, para os 
países produtores de drogas nas décadas de 80 e 90 . Parte expressiva deles foi destinada aos países andinos, produtores de toda a cocaína do planeta. Assim Colômbia, Peru e Bolívia, contaram com recursos para proteger melhor suas fronteiras e evitar a exportação das drogas para o mercado norte-americano.

Desta forma, Brasil, Argentina, Uruguai e Chile, passaram a compor rotas alternativas do tráfico de drogas, em um primeiro momento como países de rota de cocaína(28, 29). Mais tarde como estratégia do tráfico de drogas foi necessário o estabelecimento de uma base de consumo em cada um destes locais, expandindo, sobremaneira, o consumo de cocaína na região do Cone Sul da América Latina (incluindo Brasil). Da mesma forma, o tráfico de drogas passou a encetar bases do crime organizado nestes países, o que já é nítido no cotidiano das cidades do Rio de Ianeiro e em São Paulo (10).

A criação de novas rotas de tráfico, bem como o aumento do mercado interno de consumo de drogas no Brasil, em parte em função da política externa norte americana de "Guerra Contra as Drogas", trouxeram sérias consequiências para a saúde de nossa população, sendo sem dúvida a rápida disseminação do HIV em nosso meio, uma das mais relevantes.

Vale apenas ressaltar que a política norte americana embora hegemônica, não é a única vigente, e que existem países como a Holanda, Austrália, Suíça e em certa medida Grã Bretanha, que têm políticas de drogas total ou parcialmente distintas, com resultados do enfrentamento da questão bem mais promissores. Lamentavelmente, nosso País tende a seguir institucionalmente o pior dos exemplos.

\section{I.4 - Dura Lex, Sed Lex}

As drogas hoje consideradas ilícitas, nem sempre tiveram esta classificação. Cada uma delas, tem uma história própria que melhor pode ser entendida com a leitura da obra de Antônio Escohatado, A História das Drogas, em três volumes (30). Vale no entanto citar alguns exemplos de como uma mesma sociedade em tempos diferentes; ou sociedades diferentes em tempos iguais, tratam da questão da legalidade de forma tão distinta. 
A maconha, por exemplo, passou a ser proibida nos Estados Unidos da América em 1937 (31) e, até então, era comercializada normalmente. Ainda assim. mesmo com todo conservadorismo do governo dos Estados Unidos da América na questão de drogas, o uso médico da maconha é legal em 35 dos estados norte americanos e no Distrito de Columbia. Na maior parte deles, a legalidade para uso médico, foi conquistada por ampla consulta popular com base em plebiscito (32). Já na Holanda, a maconha é vendida em lugares públicos (coffee-shops), por cardápio, onde o cliente pode escolher qualidade e procedência. O Estado holandês controla até mesmo a qualidade da droga (33). No Brasil, país grande produtor de maconha, até mesmo o porte de uma pequena quantidade do produto, pode ser punido com privação da liberdade. São três exemplos distintos de como três sociedades em épocas iguais, podem reger legalmente de formas tão diferentes um mesmo fenômeno. No exemplo norte americano, vimos também que na mesma sociedade em épocas distintas, o mesmo fenômeno teve tratamento diferente.

A punição do consumo, com as exceções de alguns países (já mencionados) que lidam com a questão drogas não priorizando a abordagem bélica policial, tem sido a consequência mais nefasta da abordagem juridica tida como proibicionista. Para ficarmos no exemplo norte americano, rico em dados, o governo gasta cerca de 8,6 bilhões de dólares ao ano com pessoas presas por drogas (34). Em 2000, os Estados Unidos atingiram a cifra de 2 milhões de presos, a maioria relacionados à "Guerra Contra as Drogas".

O proibicionismo no Brasil tem seu primeiro marco legal na década de 20 e foi sendo reforçado nas leis subsequentes. A lei em vigor desde 1976 é a Lei 6368, segue a mesma direção. O Estado brasileiro estima que são gastos cerca de $7,9 \%$ do PIB do Brasil anualmente com custos relativos ao abuso de substâncias (35). Embora tecnologicamente menos desenvolvido para que se confie nos dados existentes, a situação aqui é de tanta irracionalidade quanto aquela mencionada nos Estados Unidos da América. O estado de São Paulo tomou iniciativa pioneira no campo legislativo e votou o projeto de lei do Deputado Paulo Teixeira (do Partido dos Trabalhadores - PT), regulamentada pelo Governador Mário Covas (do Partido da Social Democracia Brasileira - PSDB) em março de 1998, que autoriza os programas 
de trocas de seringas ${ }^{2}$. Em seguida o Deputado Estadual por Santa Catarina Volney Marastoni, também do PT, fez aprovar projeto de lei similar em seu estado. No ano de 2000, o Deputado Adilson Troca do PSDB do Rio Grande do Sul, teve projeto similar aprovado em seu estado. Os Municípios de Ribeirão Preto em São Paulo e São Leopoldo no Rio Grande do Sul, também tiveram leis similares aprovadas por suas Câmaras Municipais ${ }^{3}$. Nenhum outro estado ou município brasileiros protege em lei seu cidadão contra as epidemias de AIDS e outras doenças de transmissão sangüínea, pelo compartilhamento de seringas e agulhas, embora existam hoje alguns outros projetos em curso em Assembléias Legislativas e até no Congresso Nacional. O uso médico da maconha para doentes de AIDS ou de câncer por exemplo, ainda é um tema tabu em um país que trata com tanta repressão a questão das drogas.

Inúmeros trabalhos demonstram o quanto o proibicionismo dificulta, dentre outras coisas, as ações de saúde para a população usuária de drogas $(3,4,36,37,38)$. Assim, a lei que deveria ser um instrumento de proteção para a sociedade, tem efeitos colaterais perversos para esta mesma sociedade. Dentre eles, destaca-se a disseminação do HIV entre e dos usuários de drogas injetáveis.

\section{I.5 - Políticas Públicas de Drogas, incluindo Políticas Públicas de Saúde para Drogas}

Para manter a consistência do que vem sendo dito sobre drogas, as políticas públicas nesta área, são definidas pelo conjunto de fatores acima mencionados, e sobretudo por seus resultados. É certo que as políticas públicas de drogas variam de país para país. Se olharmos para o exemplo da Suíça, dos Estados Unidos da América do Norte e do Brasil, veremos três situações bastante distintas.

Cada país tem sua estratégia de redução de oferta, redução de demanda e de como lidar com as consequiências do uso de drogas para a saúde de sua população. Todos estes Estados proíbem algumas drogas.

\footnotetext{
${ }^{2}$ A Lei 9758 de 17 de setembro de 1997 publicada no Diário Oficial do Estado de São Paulo do dia posterior, "autoriza a Secretaria do Estado da Saúde de São Paulo à adquirir e distribuir seringas descartáveis aos usuários de drogas endovenosas, com o objetivo de reduzir a transmissão do vírus da AIDS por via sanguínea em São Paulo". Esta Lei foi regulamentada pelo Decreto 42.927 de 13 de Março de 1998, entrando assim em vigor.

As leis aqui referidas foram informadas por comunicação pessoal do então Deputado Estadual por São Paulo, do Partido dos Trabalhadores, Paulo Teixeira.
} 
A Suiça por exemplo, concentra a política de redução de oferta na repressão aos grandes traficantes (cada vez menos importante em sua política geral), mas e sobretudo em políticas sociais para os usuários. Se o governo oferece a droga (seja ela heroína. metadona, ou outra qualquer), controla seu uso e sua qualidade em lugares de uso seguro, o usuário não precisa gastar dinheiro com traficante. Desta forma, resolvem-se problemas sociais dos usuários de drogas, como, por exemplo, sobrar dinheiro para moradia e alimentação adequada; como ainda resolvem-se problemas de saúde, como diminuição de overdoses e de manutenção de taxas insignificantes de transmissão de HIV entre usuários de drogas injetáveis (39). Não há traficante de drogas que tenha interesse econômico de concorrer com uma política pública de drogas desta natureza. A abordagem da redução de demanda do governo suíço é de um compreensivo programa de educação escolar baseado na ciência que transmite educação e conhecimento para que as crianças, adolescentes e jovens, para que saibam discernir e se proteger. Sua proposta de recuperação dos usuários é a de Redução de Danos. Considerando a dificuldade que é a do tratamento de dependência de drogas, propõe um programa paulatino e racional, baseado nas possibilidades do indivíduo em questão; além de aceitar o fato de que há muitos usuários de drogas que não querem parar de usar, e criar condições de cidadania também para estes.

Já nos Estados Unidos da América, a repressão à oferta é feita com auxílio aos países produtores, que vai do auxílio militar, às propostas de substituição de cultivo. Além disto, há um gasto enorme de recursos financeiros com o aparato próprio para que as fronteiras, portos e aeroportos sejam protegidos contra o tráfico, visto que no país não se produzem algumas das drogas mais consumidas (heroína e cocaína). Há ainda gastos adicionais com polícias especializadas e seus equipamentos, com um sistema carcerário repleto de usuários de drogas e com outros itens que compõem este aparato jurídico policial. Este gasto fabuloso de recursos e energia que como já vimos consome $66 \%$ do orçamento de drogas do país, tem tido resultados desestimuladores, mesmo porque os Estados Unidos da América do Norte seguem sendo o maior consumidor de drogas ilícitas no mundo. Além disto, a quantidade total de droga produzida na América Latina continua idêntica nos úiumos 5 anos (1995-2000), demonstrando mais uma vez o fracasso de sua política externa 
(40). Naquele país a política interna de contenção de demanda pautada na filosofia da Guerra Contra as Drogas, e é baseada em atividades como o DARE - Drug Abuse Resistance Education (PROERD - Programa de Resistência às Drogas - no Brasil), para transmitir às suas crianças, adolescentes e jovens o pensamento mais refinado desta filosofia que é o simplesmente diga não às drogas (ou just say no). Estudos realizados por diversos pesquisadores, demonstram a ineficácia destes programas $(41,42)$. A abordagem terapêutica ou de recuperação do usuário, é principalmente de abstinência, com a existência de umas poucas clínicas de metadona, insuficientes para cobrir a enorme demanda do país. As críticas vão desde a falta de locais de tratamento em todos os bairros ou cidades, até o fato de metadona não poder ser prescrita por um médico, aviada em farmácia, e o paciente tomar como o faz com inúmeros outros medicamentos (3). Iniciativas como os programas de trocas de seringas espalhados pelo País principalmente por entidades da sociedade civil e universidades, não contam com apoio financeiro do Governo Federal.

O Brasil segue prioritariamente, o modelo norte americano, com algumas exceções que também naquele país existem. O modelo de Política Pública de Drogas Brasileiro foi constituído em meio ao regime militar de 1964. A Lei 6368 de 1976, tinha inspiração no Modelo de Segurança Nacional, que pode ser observado em vários de seus artigos. O Sistema Nacional de Drogas, constituído por decreto com base na referida Lei, mantinha uma postura centralizadora de poder e de interesses da União. Apesar disto, o Conselho Nacional de Entorpecentes seguiu a orientação geral do Estado brasileiro de independência nas relações internacionais. Se de um lado, durante anos o Conselho teve orientação bélica e priorizou a chamada "ajuda" militar norte-americana, nos anos mais recentes (sobretudo depois da redemocratização do país), do mesmo Conselho Federal de Entorpecentes saíram resoluções técnicas mais independentes e até dossiês de denúncia de tentativas de intromissão norte-americana em nossos assuntos internos. Um exemplo de independência foi a resolução que em 1994 aprovou a iniciativa do Ministério da Saúde de trocar seringas para prevenir a disseminação de HIV entre usuários de drogas injetáveis. Assim contraditoriamente, o Brasil foi sempre pressionado por todas as formas a adotar a estratégia de combate às drogas propostos pelos norte-americanos, embora nem sempre tenha cedido a estas pressões. Ademais das formas de intromissão mais ousadas e diretas, outras 
formas ganharam corpo no País como a penetração massiva de Programas como o PROERD (DARE nos Estados Unidos), que foram negociados diretamente entre o Drug Enforcement Agency dos Estados Unidos (DEA) e as Policias Militares de diversos Estados brasileiros, apesar da oposição oficial da maioria dos Conselhos de Entorpecentes das diversas esferas.

Uma das mais recentes tentativas de ingerência em assuntos internos do Brasil foi a criação da Secretaria Nacional Antidrogas (SENAD) organizada em meados de 1998. Há sólidos indícios de que ela tenha sido gestada por interferência direta do ex-presidente Bill Clinton, cobrando o auxilio do governo norte-americano à política econômica do Brasil. Inspirada em molde clássico adaptável a qualquer país latino americano a idéia da estrutura nacional antidrogas ligada à Presidência da República do País, não foi nenhuma idéia original (43). Entretanto, como as adaptações de importados ao Brasil nem sempre seguem à risca o original, a Secretaria Nacional Antidrogas tem fugido bastante à proposta de uma submissão pura e simples aos interesses regionais da América. Seu Fórum de debates realizado em 1998 (35), tem alguma de suas resoluções contraditórias ao espírito de "Guerra Contra as Drogas". Chega ao avanço de colocar pela primeira vez na história, de maneira mais explícita, em um documento oficial do governo brasileiro (e não mais documentos de um setor específico do Governo), que as estratégias de redução de danos estão elencadas entre uma das possíveis políticas públicas do governo brasileiro na abordagem do fenômeno das drogas. Seu primeiro Secretário Geral, o juiz paulista Walter Maierovich, defendia, publicamente, a substituição de drogas como uma das possibilidades no tratamento de dependentes. Apesar disto, a orientação programática da SENAD priorizou para os primeiros anos de suas atividades a questão da repressão. É difícil avaliar as conseqüências da queda de Maierovich ocorrida em abril de 2000. O movimento de redução de danos no País vem, no entanto, acumulando vitórias que se refletem na política da SENAD. Em um Seminário Latino Americano Itinerante ocorrido em Recife em setembro de 2000, o General Alberto Cardoso que além de Ministro Chefe do Gabinete Institucional da Presidência da República, acumula a função de Secretário Nacional Antidrogas, fez uma declaração de que é favorável pessoal e institucionalmente à reduçãu de danos(44). Ainda no mês de agosto de 2000 o governo do Brasil deu mais sinais de 
independência em sua política externa quando o Ministro das Relações Exteriores Luiz Felipe Lampreia rejeitou a proposta de intervenção militar na Colômbia feita pelo governo norte-americano a título de combater o tráfico de drogas (o Plano Colômbia).

Enfim, embora a pressão norte-americana para fazer ingerência sobre a política de drogas brasileira não possa ser subestimada, na prática ela não tem sido realizada exatamente como eles gostariam. Como já vimos em parágrafos anteriores, esta influência em nada ajudaria a enfrentar as dificuldades geradas pelo uso abusivo de drogas em nosso País, pois sequer nos Estados Unidos se conseguiu solução satisfatória para um problema tão relevante.

Na questão das políticas de saúde para usuários de drogas o País também teve seus diversos momentos. Há um debate permanente sobre a forma mais adequada de condução de tratamento de usuários de drogas, tendo predominado, até então, os modelos de auto ajuda; psiquiátrico tradicional; e os psicoterápicos. A dificuldade de uma definição sobre quem é doente, e quem precisa de tratamento é até mesmo um problema anterior. Há consenso no entanto de que há falta de locais para tratamento, sobretudo para tratamento do tipo público e ambulatorial. Esta discussão em certa medida questiona o modelo médico de tratamento por uma lado, abrindo porém a oportunidade a uma enorme proliferação de locais alternativos de tratamento, muitos dos quais sem nenhuma orientação cientifica. Há, recentemente, um crescimento desproporcional de comunidades terapêuticas com orientação religiosa ou não, que funcionam, geralmente, com financiamento público, mas sem nenhum controle de qualidade.

No Ministério da Saúde, durante muitos anos, a Coordenadoria de Saúde Mental foi a responsável pela orientação sobre o tratamento do usuário de drogas no Brasil. De fato, a questão do tratamento do usuário de drogas nunca foi compreendida como importante para a saúde mental. Recentemente, após a criação da SENAD, uma de suas sub-secretarias é dirigida à prevenção e tratamento, e tem procurado canalizar os debates em torno desta questão. Há registro formal de apenas um serviço que admite experimentar redução de danos como uma das formas de abordar o tratamento de dependência de drogas de seus clientes no Brasil (PRCAD 
da Universidade Federal de São Paulo), embora o número de serviços com esta perspectiva seja de fato um pouco maior.

$\mathrm{Na}$ interseção entre drogas e AIDS há um clima um pouco mais favorável às ações de saúde para usuários de drogas que serão tratados em outra parte deste texto.

Na questão da prevenção o País não tem uma política única, o que possibilita a proliferação de varias políticas, muitas vezes sob o mesmo patrocinador. Durante um debate da campanha eleitoral de 1998 para Governador de Estado, o candidato e governador Mário Covas, elogiou o PROERD como sendo uma medida adequada para controlar o consumo de drogas entre adolescentes. Esta estratégia preventiva conduzida nas escolas pela Policia Militar, não tem o apoio formal da Secretaria da Educação do Estado que conduz outro Programa de Prevenção completamente antagônico ao PROERD, o "Prevenção Também se Ensina”. Alem disto, o PROERD ainda conta com a oposição formal do Plenário do Conselho Estadual de Entorpecentes de São Paulo - três órgãos subordinados ao mesmo Governador, com políticas preventivas tão diferentes. O exemplo do Governo do Estado de São Paulo, se reproduz Brasil afora alimentando a indefinição sobre a melhor política pública de prevenção ao abuso de drogas. A amplitude com que o documento do Fórum da SENAD tratou do tema, reforça esta falta de uma política governamental clara no assunto (35).

É evidente que uma orientação adequada em relação às políticas públicas (ou as vezes a falta de uma), pode ser um dos importantes determinantes de condições de saúde mais adequadas para a população. Uma política pública centrada, prioritariamente, na repressão é excludente e prejudicial às políticas sociais no geral e particularmente às políticas de saúde. No conceito de vulnerabilidade coletiva, as políticas de saúde (ou respostas do Estado) são consideradas determinantes do ritmo de desenvolvimento da epidemia de HIV.

\section{I.6 - Estratégias de Redução de Danos}

É complexo e não muito nítido o conceito de redução de danos (12). No entanto uma série de características e uma idéia comum, são, majoritariam nte, aceitos como pertencentes a esta linha de pensamento e ação para lidar com a questão das drogas. O fracasso da estratégia bélica/abstinente do fenômeno drogas já 
foi bastante analisado nos itens anteriores deste trabalho, e da mesma forma por outros autores $(5,26,38)$. Vale a pena aqui portanto, enfatizar aquilo que é uma política alternativa, pragmática e bastante promissora. As estratégias de redução de danos devem ser vistas no contexto de uma política pública, demonstradamente, capaz de reduzir a vulnerabilidade individual e coletiva.

A idéia comum mencionada é a de que o uso de drogas existe (e é crescente, independentemente de nossa vontade) e que uma série de usuários não vão interromper o uso, seja por que não desejam, seja por que não conseguem.

Três princípios básicos das estratégias de redução de danos serão aqui mencionados:

1. É possível criar um ambiente mais seguro para que o uso de drogas seja menos prejudicial à saúde;

2. Existem tratamentos alternativos à abstinência.

3. Os usuários de drogas podem ser um importante elemento nas intervenções de prevenção e tratamento, bem como nas atividades civis (protagonista); e não devem ser vistos como incapazes;

\section{I.7 - A Idéia Comum}

O uso de drogas, como já foi visto, é um fenômeno que tem sua história vinculada à história da humanidade. Se analisarmos apenas os anos recentes, verificaremos que a indústria do tráfico de drogas e das atividades paralelas que se beneficiam dele, são poderosos conglomerados econômicos que não tendem a diminuir, senão a expandir seus negócios. Para isto, claro que contam com consumidores em todo o mundo, incluindo o Brasil, não obstante sua predileção por mercados mais lucrativos.

Numerosas são as razões que levam as pessoas a consumirem drogas $(8,45)$. A maioria dos consumidores de drogas, o fazem sem serem dependentes, mas é crescente o número de dependentes de drogas.

Há dois problemas cruciais ao associar o controle da epidemia de HIV e o tratamento de usuários de drogas injetáveis: a) ao propor tratamento com base na abstinência, os melhores serviços no mundo com esta filosofia têm baixo êxito; b) e é 
sabido que os usuários de drogas demoram por vezes anos para ir em busca de ajuda(46).

A proposta de enfrentar a questão das drogas partindo do pressuposto de redução de danos, é bastante mais racional do que lutar por um mundo "livre das drogas", como deliram alguns dos mais fervorosos defensores da abstinência nesse planeta em seus diversos níveis (membros dos poderes executivo, legislativo e judiciário, terapeutas, membros da sociedade civil conservadora e outros).

\section{I.8 - Princípio 1, “Uso Mais Seguro”.}

Para muitos há uma antítese na expressão "uso mais seguro" de drogas. Para outros esta expressão é completamente inadequada. Para aqueles que como nós, estudam e compreendem as estratégias de redução de danos, este é o melhor resumo do pragmatismo das ações propostas.

O uso mais seguro de drogas, surgiu mais recentemente com a epidemia de AIDS como uma proposta de que ao usar drogas, as pessoas evitassem os riscos de infecção pelo HIV. De fato, sua origem contemporânea, foi em função de uma epidemia de hepatite do tipo B por compartilhamento de seringas e agulhas pelo uso injetável de drogas na Holanda, ainda anterior à disseminação do HIV pela mesma via, em meados dos anos 80 (47).

$\mathrm{Na}$ história, o uso mais seguro remonta o início do século XX, quando Sir Humphrey Rolleston então Presidente do Colégio de Médicos do Reino Unido, presidiu uma Comissão que levou seu nome (entre 1924 e 1926) e que propôs iniciativas na área jurídica e na área médica que melhorassem a qualidade de vida e aumentasse a tolerância com os usuários de drogas(12).

Mais recentemente, as alternativas relativas à diminuição da transmissão de patógenos de veiculação sangưínea, foram principalmente a troca ou distribuição de seringas individuais para estimular o não compartilhamento, ou ainda a distribuição de hipoclorito de sódio, para realizar a desinfecção de seringas e agulhas contaminadas. Esta prática foi tão importante para conter a epidemia de HIV/AIDS, que muitas vezes a estratégia de redução de danos como um todo, foi erroneame ate confundida e resumida a trocar seringas. 
Mas o uso mais seguro, que é apenas um dos princípios da redução de danos, também não se limita só a estas medidas já mencionadas (48). Um auxiliar de enfermagem, via de regra de formação bastante rudimentar, pode ser treinado para aplicar uma injeção intravenosa sem causar danos ao paciente. Medidas como as de assepsia da pele, ou onde e como injetar a medicação, evitam flebites, abscessos e até mesmo casos mais graves como endocardites bacterianas. Da mesma forma, um usuário de drogas (ou um diabético) podem, e devem, ser treinados para a auto aplicação de drogas, evitando-se conseqüências desnecessárias à saúde.

A qualidade, quantidade e outras orientações sobre a droga em si, pode evitar overdoses, fatais ou não, mas sempre com complicações para a saúde do usuário de drogas. Além disto, ensinar os primeiros socorros aos usuários de drogas que podem eventualmente, estar presentes a uma situação de overdose, pode em muitos casos, ser um divisor entre a vida e a morte.

Embora seja bastante comum o trabalho de orientação sobre HIV e AIDS para estas populações, mesmo em áreas tradicionais de trabalho de prevenção entre usuários de drogas injetáveis como a Região Metropolitana de Santos, o trabalho de

łação sobre hepatites B e C é inexistente (49). O mesmo raciocínio pode ser ruicado à overdose (50). É possível, e necessário, desenvolver estes conhecimentos nesta população específica.

Outras medidas simples de orientação, sobre onde e como utilizar drogas, podem evitar para o cliente complicações desnecessárias com a polícia e a justiça. No caso do Brasil, sabemos que o fato do usuário ser preso em um sistema carcerário caótico, só vai agravar suas condições básicas de vida e de saúde.

Enfim, há uma série de iniciativas que podem ser tomadas pelos serviços de saúde para que os usuários de drogas tenham suas condições de saúde melhoradas.

\section{I.9 - Princípio 2: Abstinência não é Tudo}

A proposta de abstinência ou nada para o tratamento de dependência de drogas é uma proposta que ainda é hegemônica em nosso país e na maior parte dos países do mundo. No entanto, esta hegemonia, não se respalda em resultados positivos desta forma de tratamento, nem ao menos em comprovação científica sobre 
eficácia deste tipo de tratamento. Da mesma forma que é difícil que o dependente da droga nicotina, encontrada no tabaco legalmente vendido, interrompa seu uso, o dependente de outras substâncias não encontra facilidade de sair do uso contínuo para a abstinência, sem escalas.

Uma comparação ilustrativa desta forma radical de abordagem, é a feita com os tribunais de inquisição da idade média. Ali também existiam duas únicas possibilidades: a conversão ao cristianismo, ou a fogueira.

Há, evidentemente, casos em que o dependente escolhe este tipo de tratamento, e ele e os serviços que se propõem a fazê-lo, devem ser respeitados. Vale ressaltar que existem serviços de tratamento que se propõem a uma gradação, com a manutenção do objetivo estratégico da abstinência, sem no entanto fazer um contrato de cláusula única. São ainda excepcionais, e não têm motivação filosófica similar aos de redução de danos, mas são um considerável avanço. Há um consenso em construção (que só exclui os radicais pró abstinência exclusiva) de que deva existir uma plêiade de alternativas de tratamento que possibilite a cada cliente, na sua condição conjuntural, poder decidir sobre qual a que ele se adapta.

Os serviços de tratamento de dependência de drogas orientados para redução de danos, aceitam diversos contratos, que vão do uso controlado da substância que a pessoa normalmente utiliza, até as terapias de substituição de drogas.

Nos casos de uso controlado, trabalha-se uma escala decrescente de risco, normalmente associados à via de utilização ou à quantidade, para que o dependente perceba uma gradação de mudanças. Pequenos passos que levam o usuário a sair de uma forma descontrolada de uso, para um uso mais seguro e menos danoso para sua saúde. Por exemplo, ao propor que a pessoa utilize a cocaína aspirada em substituição à cocaína injetada, busca-se que os prejuízos à saúde sejam menores que os esperados na forma anterior de uso.

Nas terapias de substituição, geralmente se utilizam drogas com princípio ativos similares (heroína e metadona; cocaína e folha de coca; ou até heroína de rua por heroína do serviço de saúde com controle de qualidade) (39, 51). Alguns trabalhos mostraram o sucesso de substituir drogas diferentes como cocaína em forma de pedra de crack fumada, por maconha, também fumada (52). 
Enfim, estas propostas de tratamento não se fecham em torno de uma exigência absoluta, mas ao contrário, respeitam o momento do usuário e buscam melhorar sua qualidade de vida, ainda que sob o uso de substâncias.

\section{I.10 - Princípio 3: Usuário de Drogas, Cidadão e Agente de Saúde}

Que papel está reservado ao usuário de drogas nas estratégias de redução de danos? Esta questão diferencial, será melhor explorada em item a parte, como forma de ressaltar sua importância, mas se coloca como um dos princípios básicos das estratégias de redução de danos.

A sociedade costuma tratar os diferentes de uma forma não muito amigável. Os portadores de deficiência e de distúrbios mentais são exemplos ao alcance de todos. Também se tentou considerar durante anos, e algumas correntes insistem em fazê-lo, os usuários de drogas como seres a parte, incapazes de responder pelos seus próprios atos. Isto acaba justificando medidas como internação compulsória, interdição judicial, perda de pátrio poder, dentre outras medidas violentas contra o usuário de droga ilícita.

Na visão de quem aborda o fenômeno drogas com o olhar de Redução de Danos, o usuário é um cidadão como qualquer outro, e com a mesma capacidade de desempenhar papéis importantes para a sociedade em que vive. Desta forma, muitos dos programas de redução de danos, sobretudo os de prevenção, são conduzidos por pessoas que estão em pleno uso de drogas. Fora do Brasil, é comum a pratica associativa de usuários de drogas que se organizam em entidades, que dentre outras atividades, fazem o trabalho de educação de seus pares. Assim, associações de usuários de drogas, normalmente financiadas pelos governos de seus países (Austrália, Alemanha, Holanda, dentre outros), produzem e distribuem materiais educativos, distribuem seringas e outros utensílios necessários ao uso seguro de drogas, além de organizar cursos e treinamentos para sua clientela e representar seus iguais em conselhos políticos e científicos (53).

Mesmo no Brasil, uma boa parte dos programas de Redução de Danos conta em seus quadros com usuários de drogas em atividade. Com menos independ acia, mas com um trabalho fundamental, os usuários levam algumas vantagens como 
Redutores de Danos: têm a mesma linguagem, experiência de vida e possibilidade de penetração em meios que pessoas de fora não teriam acesso $(9,54)$.

Assim, o usuário de drogas aqui é visto como um ser ativo, capaz e útil para seus pares e para a sociedade como um todo (protagonista); e não relegado a um papel passivo menor como no passado.

\section{I.11 - O usuário de drogas, injetáveis e de outras drogas}

A forte criminalização do uso de drogas em nosso País, é o provável motivo da enorme dificuldade de acesso que os programas oficiais têm a esta população específica. Este fenômeno não é exclusivo do Brasil, mas vamos concentrar no problema em nosso meio, para melhor compreender sua inter relação com a epidemia de HIV/AIDS (38).

Já abordamos a questão legal anteriormente, vimos como ela afeta as condições de saúde, mas é interessante apresentar um outro angulo da questão, ou a questão vista pelo olhar do usuário de drogas. Se fizermos um paralelo com o movimento Gay, ou com as organizações de prostitutas, veremos que determinados setores sociais no Brasil têm dificuldades históricas de exercer sua cidadania. Moralmente "condenados" pela sociedade, não é fácil que as pessoas se assumam como sendo homens que fazem sexo com homens ou prostitutas, e que mais que isto, se sintam "iguais perante a Lei" como reza nossa Constituição. Esta contradição que emergiu na epidemia de AIDS, expôs de maneira clara a existência destes segmentos da sociedade, e mais que isto, motivou e possibilitou a sua organização. Desta forma, direitos básicos de qualquer cidadão brasileiro, passaram a ser considerados também direitos destes segmentos. O mais importante deles é possivelmente o Direito a Não Discriminação. Algumas Constituições Municipais (Leis Orgânicas de Municípios) foram mais longe e garantem hoje em lei que a discriminação por orientação sexual não é tolerada. Com iniciativa originária do Grupo Gay da Bahia, a cidade de Salvador foi a primeira cidade do Brasil a colocar em sua Lei Orgânica Municipal no artigo que elenca os motivos pelos quais o cidadão não pode ser discriminado, o de sua orientação sexual. Desde então, 73 municípios e 2 Estados no Brasil até i 398 tinham em suas Leis Orgânicas texto similar (55). Ainda é pouco, pois não há 
previsão em nenhuma destas leis do que fazer se a discriminação acontecer. Mesmo assim, há no geral uma diminuição da discriminação contra estes segmentos, o que vem sendo fundamental na sua mobilização e conscientização na luta contra a AIDS e as DSTs. Em junho de 2000 a cidade de São Paulo assistiu a uma parada Gay de mais de 100 mil pessoas. No entanto ser Gay ou prostituta no Brasil não é crime. O que não é verdade para ser usuário de drogas ilícitas.

Além da discriminação hipócrita da mesma sociedade que comemora as festividades com o álcool, droga legal, e discrimina quem utiliza drogas ilegais, este comportamento é criminalizado em nosso meio. Alguns, principalmente delegados de polícia, promotores e juizes, dirão que o uso de drogas ilícitas não é criminalizado no Brasil. É uma meia verdade, desmentida pela realidade dos presídios repletos de usuários de drogas, que muitas vezes são presos pelo "porte" de drogas, crime previsto na legislação brasileira. Interessante pensar como pode alguém que não porta droga, consumi-la.

Esta situação de discriminação e crime, torna o usuário de drogas um cidadão particular que perde direitos como a liberdade de expressão, liberdade de organização, liberdade individual de utilizar em sã consciência a substância que bem entenda desde que não cause mal a outrem, dentre outros direitos, conforme prevê nossa Constituição no Capítulo de Liberdades Individuais. Sem mencionar que usuários de drogas são vítimas constantes de violações de direitos humanos como por exemplo a perda do pátrio poder de mães que são usuárias de drogas, as quais a maioria dos magistrados, não dá oportunidade de exercer a maternidade.

Além da dificuldade de organização e expressão, muitas vezes o usuário é privado de emprego, escola, assistência à saúde, religião, dentre outros direitos, pelo simples fato de ser usuário de drogas. Para agravar esta situação, poucos são os serviços de saúde preparados para receber e serem atrativos aos usuários de drogas, incluindo ai muitos dos serviços que trabalham com a causa da luta contra a discriminação, como os serviços de DST e AIDS.

No Brasil a tentativa embrionária de criar uma entidade de usuários de drogas não logrou êxito, provavelmente por esta situação de intensa proibição. Entidades como a ABORDA (Associação Brasileira de Redutores de Danos) e outras simi ures, mantém desde sua fundação um caráter indefinido, tendendo a ser importantes meios 
de aglutinar "redutores de danos", que são trabalhadores dos serviços de saúde ou de organizações não governamentais (13). É fundamental que os redutores de danos se organizem, mas isto não resolve o problema da falta de organização dos usuários de drogas. Ainda no Brasil, foi fundada em 1998 a Rede Brasileira de Redução de Danos (REDUC) e na América Latina a Rede Latino Americana de Redução de Danos (RELARD) (56). Estas duas iniciativas congregam principalmente técnicos com responsabilidade de pensar e conduzir políticas de redução de danos em suas áreas de atuação, bem como de defender estas idéias no Brasil e na América Latina respectivamente. Embora estas iniciativas sejam boas, segue um vazio no Brasil de uma voz própria de defesa dos interesses dos usuários de drogas, similar as que existem em países como a Inglaterra, Holanda e até mesmo nos Estados Unidos da América, como já mencionado anteriormente. Os usuários de drogas continuam sendo defendidos por profissionais (de serviços de saúde ou "redutores de danos"), e por terem a seu favor apenas voz externa, não têm a mesma força de pressão que outros setores mais organizados. Mesmo considerando que uma parte dos "redutores" é de usuários de drogas em atividade, o fato é que tem sido difícil colocar na agenda as questões que mais afetam os usuários de drogas. Se considerarmos por exemplo a Ata da última Assembléia Geral Ordinária da ABORDA datada de 9 de novembro de 1999, não há uma só citação da palavra "usuário de droga" em todo o texto, a não ser menção indireta a este personagem. $\mathrm{O}$ mesmo ocorre em seu boletim de número 2 (novembro a dezembro de 1999), onde o usuário de drogas é tratado quase sempre na terceira pessoa do plural. No editorial do referido boletim, é apontada a luta de três anos "em busca da auto organização dos usuários de drogas"(57). Números subsequentes do boletim da entidade entram em questões importantes dando aos usuários seu papel de protagonistas nos projetos de redução de danos em curso, mas mesmo assim não se identificam como sendo uma associação de usuários de drogas.

Esta situação se reflete também nas políticas públicas. Há hoje por exemplo poucos serviços públicos que trabalhem a importância de prevenir as hepatites entre usuários de drogas, mesmo considerando que em todo o mundo estima-se que 177 milhões de pessoas estão infectadas pelo vírus da hepatite $\mathrm{C}$, a maioria delas UDIs(58). Destas, o prognóstico é que $85 \%$ desenvolveriam a forma crônica da doença e $20 \%$ deles poderiam evoluir para cirrose ou câncer de fígado(59). O 
tratamento, além de não ser eficiente em mais do que metade dos casos para alguns genotipos, em geral não está disponível na rede pública de saúde. No que diz respeito ao acesso à vacina de hepatite $\mathrm{B}$, os usuários de drogas não se encontram elencados em nenhum documento oficial no Brasil como um dos grupos prioritariamente imunizáveis, ressaltando a exceção da vacinação de hepatite $B$ que vem sendo realizada no Programa de Redução de Danos do Rio de Janeiro e de São Vicente. Não há também menção de iniciativas para a prevenção de overdoses relacionadas ao uso de cocaína no Brasil.

Com raras exceções, capitaneadas pelo IEPAS e a Coordenação de DST/AIDS de São Vicente, até 1999, havia apenas um material produzido sobre o uso mais seguro de drogas destinado aos usuários de drogas. Este material havia sido reproduzido em Sorocaba e São José do Rio Preto.

No total de recursos públicos empenhados nos programas de prevenção de DST/AIDS, não há um crescimento proporcional ao tamanho da epidemia de recursos públicos para este setor no Governo Federal ou em Governos Estaduais ao longo dos anos. Em Municípios cuja transmissão de HIV têm um importante componente de UDIs, também não se destinam recursos orçamentários ou de convênios suficientes para intervenções neste setor. Há inclusive dispersão dos poucos recursos existentes em atividades não diretamente relacionadas aos usuários de drogas injetáveis (como projetos em escola e na comunidade), e que têm sua eficácia ainda não comprovada.

Assim, o público alvo deste trabalho é um público marginalizado, criminalizado, desorganizado e com pouca capacidade de pressão para melhorar suas condições de vida e saúde. Os resultados dos estudos que apresentaremos adiante, vêm corroborar esta afirmação.

\section{I.12 - Breve Histórico da Redução de Danos no Brasil}

Em dezembro de 1989 no Governo Democrático e Popular da Cidade de Santos dirigido pela Prefeita Telma de Souza (PT) foi realizada a primeira tentativa de implantar um programa de redução de danos no Brasil. Impedidos de trocar seringas em seus serviços de prevenção de AIDS, os técnicos da Coordenação Municipal de DST/AIDS de Santos construíram alternativas como estimular o uso de 
hipoclorito de sódio para a desinfecção de agulhas e seringas reutilizadas. Mais tarde, em 1993, uma organização não governamental, o Instituto de Estudos e Pesquisas em AIDS de Santos - IEPAS, com recursos do Programa Nacional de DST/AIDS do Ministério da Saúde, implantaria o primeiro projeto no Brasil a utilizar "redutores de danos" para o trabalho de prevenção de HIV/AIDS entre os seus pares (9). Em 1995, Dr. Tarcísio Andrade coordenador do Projeto de Redução de danos do CETAD da UFBa, implantou apesar de toda oposição ao seu propósito, o primeiro projeto "tolerado" de troca de seringas no Brasil. $(60)^{4}$

Dai em diante, abriram-se numerosas barreiras e aos poucos os projetos foram se expandindo. O estado de São Paulo, foi palco de dois grandes marcos desta política pública de saúde: a promulgação da Lei do Deputado Estadual Paulo Teixeira (já citado) e a realização em março de 1998 da $9^{\text {th }}$ Conferencia Internacional de Redução de Danos. A Conferência aberta no Palácio dos Bandeirantes, reuniu delegados de 50 países do mundo e teve grande repercussão na mídia brasileira (14). Em junho de 2000, existiam 22 projetos de redução de danos em curso no Brasil, 14 no Estado de São Paulo, todos patrocinados com recursos públicos, majoritariamente Federais ${ }^{5}$.

Apesar das numerosas vitórias políticas conquistadas nestes 10 anos de luta pela implantação das estratégias de redução de danos no Brasil, devemos reconhecer que:

- sua implantação foi limitada a poucos projetos, poucos recursos humanos e pouco recursos financeiros;

- os projetos em sua maioria são desenvolvidos marginalmente ao Sistema Único de Saúde, com pouca integração formal com outras instâncias;

\footnotetext{
4 Programas de Redução de Danos (ou de "outreach workers"), são programas que buscam o usuário de drogas de forma ativa em seu local de uso e/ou moradia, com uma proposta de educação continuada. Geralmente seus agentes de saúde (aqui no Brasil chamados de Redutores de Danos) são ex-usuários, usuários em atividades ou até mesmo profissionais de saúde não preconceituosos quanto ao uso de drogas. Sua função é remunerada e exercida após treinamento.

Programas de Troca de Seringas, são programas que visam fornecer seringas individuais e estéreis na maior quantidade possível aos usuários de drogas injetáveis. No Brasil, na maioria das vezes, são recolhidas as seringas utilizadas na base $1 \times 1$. Podem ser feitas pelos redutores de danos nas rus; em unidades móveis (tipo kombi ou Van); em pontos fixos (Unidades de Saúde) e/ou em farmácias.

${ }_{5}$ Informação prestada por Denise Doneda, responsável pelo setor de drogas e AIDS da Unidade Técnica de Prevenção da CN DST/AIDS do Ministério da Saúde do Brasil.
} 
- seu espectro de ação em nosso meio é limitado, não tendo na maioria dos lugares atingido todos os setores que necessitam de seu trabalho na comunidade.

Muito ainda é preciso caminhar para transformar esta enormidade de boas intenções em uma política pública de saúde.

\section{I.13 - Revendo a Bibliografia Brasileira sobre uso de drogas do Final do Século XX}

A questão do uso de drogas injetáveis e de usuários de drogas não institucionalizados, vem sendo estudada no Brasil sobretudo a partir da década de 1990. Um dos clássicos Estudos brasileiros, que sempre pautou as opiniōes sobre o assunto, foi a série histórica de estudos de consumo de drogas entre escolares desenvolvidos por Carlini e colaboradores (61). De enorme relevância para a compreensão do fenômeno entre escolares e de certa forma da população geral, o trabalho ainda não respondia a questão do uso de outras drogas como a cocaína por exemplo.

Coube ao estudo Multicentrico da OMS, desenvolvido em 1991/1992 nas cidades de Santos e do Rio de Janeiro, o início do conhecimento desta realidade. Aqui se identificou uma série de informações importantes, sobretudo quanto ao intenso uso de cocaína injetável, altas taxas de compartilhamento de agulhas e seringas, e taxas de soroprevalência que variaram de $63 \%$ em Santos a $34 \%$ no Rio de Janeiro. A idade da primeira injeção foi em média de 17 anos de idade (15).

$\mathrm{Na}$ metade da década de 90, coube ao Projeto Brasil, concebido como um estudo Multicentrico para expandir o conhecimento da situação do uso de drogas injetáveis para alem das fronteiras da Região Sudeste do país (Rio de Janeiro e Santos), o papel de obter um quadro nacional mais amplo(17). Confirmaram-se informações sobre o uso de cocaína injetável (mais de $90 \%$ em todas as cidades envolvidas) e idade do primeiro uso de drogas. Algumas alterações pontuais, não se traduziram de fato na diminuição do comportamento de risco de compartilhar agulhas e seringas. As taxas de soroprevalência variaram de $28 \%$ no Rio de Janeiro a $71 \%$ em Itajaí (Santa Catarina). É, então, registrado o aumento do consumo de crack 
na cena nacional, com taxas que vão de $36 \%$ de consumo em Salvador e no Rio de Janeiro a $61 \%$ na Região Metropolitana de Santos e na Região Centro Oeste do país(17).

Ainda em meados da década de 90, Carlini e colaboradores desenvolveram como parte de um estudo conduzido pela OMS sobre cocaína, outro estudo relevante para a compreenssão do consumo desta droga em nosso meio. Desafortunadamente a OMS nunca publicou o resultado total do estudo, mas a parte brasileira já referida foi publicada no Jornal Brasileiro de Psiquiatria em 1995 (8).

Outro estudo importante que também ajudou compreender o quadro do consumo de drogas no país, foi o inquérito domiciliar desenvolvido por Carlini e colaboradores no Estado de São Paulo, publicado no ano 2000 (62). Este trabalho desenvolvido no Estado de São Paulo trouxe informações sobre o consumo de drogas na população geral. Embora encostas domiciliares sejam difíceis de conduzir quando se busca informações sobre questões tão pessoais quanto consumo de drogas, o referido trabalho tem sido reconhecido como de extrema importância.

Os últimos dois anos da década de 90 foram profícuos em estudos e publicações a respeito do consumo de drogas ilícitas no Brasil por populações distintas, e os riscos de transmissão de HIV e hepatites. Na maioria deles aparece um importante crescimento do consumo de crack fumado, com risco atribuído ao relaxamento do uso de preservativos no relacionamento sexual, sobretudo entre as mulheres. Nenhum dos autores tenta uma associação direta entre crack e transmissão de HIV, mas alguns deles, mantêm uma hipótese de aumento do risco de transmissão sexual secundário a um provável estímulo às interações sexuais desprotegidas. O uso de drogas injetáveis é em geral apontado como um padrão de consumo em decadência, ou pelo menos em transição. Os trabalhos mencionados não estabeleceram uma associação entre as mudança no padrão de consumo de drogas com as tendências do desenvolvimento da epidemia de HIV/AIDS (63, 64, 65, 66, $67,68)$.

Sobre mudança de perfil de consumo de drogas no Brasil, o trabalho mais relevante foi publicado na revista Addiction em 1999, e tem origem em Dunn e Laranjeiras. Discorrendo sobre transição nos padrões de consumo de cocaina, o 
trabalho reporta sob uma ótica de indivíduo, o que pode ser fator de transição de padrão de consumo de drogas (46).

\section{I.14 - A Saúde no Brasil}

A população brasileira total é de 169.544.443 hab. dos quais 36.966 .527 hab. estão no Estado de São Paulo, segundo os dados preliminares do Censo Demográfico de 2000 do IBGE (69). Num país com distintas realidades regionais e enorme território, a situação de saúde é cronicamente precária. 0 PIB per capita é de RS $4.958,42$ no país, o que certamente é um dos fatores determinantes desta situação. No ano de 1996 , a proporção de analfabetismo varia de $33.23 \%$ da população de Alagoas a $5,99 \%$ no Distrito Federal, com uma media nacional de $14,71 \%$. A esperança de vida dos brasileiros ao nascer é de 64,09 anos para homens e 71,70 anos para mulheres, com uma média de 67,78 anos (70).

Se depender de quanto o Governo Federal investe em saúde, o quadro é desanimador. O Governo Federal gasta cerca de 4,6\% de seus recursos totais com saúde, correspondendo a cerca de $3,17 \%$ do produto interno bruto do País. No final do ano 2000 uma Emenda Constitucional aprovada pelo Congresso Nacional pautada na proposta original do Deputado Eduardo Jorge do PT, estabeleceu financiamento estável para o setor envolvendo todos os níveis de governo (Federal, Estadual e Municipal) com comprometimento de percentuais progressivos de suas receitas orçamentárias. Se regulamentada e cumprida, esta pode acarretar uma melhora substantiva para a situação de carência de recursos no setor.

A cobertura das ações de saúde é precária no Brasil sendo que há 3,6 leitos hospitalares para cada 1000 habitantes, mas apenas 0,9 deles são públicos. O número de médicos por 1000 habitantes varia de 0,37 no Acre a 2,78 no Distrito Federal, passando pelos 1,95 do estado de São Paulo (70).

Os indicadores de saúde não são melhores que os indicadores sócio econômicos ou de cobertura. Ainda no ano de 1996, o coeficiente de mortalidade infantil permanece bastante alto no Brasil, se comparado a outros países,.com uma media nacional de 37,39 mortes para cada mil pessoas nascidas vivas (variand de 19,66 no Rio Grande do Sul, para 74,07 na recordista Alagoas). Este mesmo coeficiente é de 24,63 no Estado de São Paulo, um dos melhores do país, mas ainda 
muito alto. Na mortalidade geral o Brasil tem uma taxa de 7,08 mortes para cada 1000 habitantes, com uma importância balanceada entre causas ligadas ao desenvolvimento e aquelas ligadas a pobreza (70).

Doenças endêmicas vão e voltam no Brasil, mas deixam um rastro que parece intransponível. Tuberculose, malária, doença de chagas, dengue, cólera, hanseníase dentre tantas outras, não são controladas, apesar da tecnologia disponível há muito para tanto, e seguem disputando parcos recursos entre si.

O Sistema Único de Saúde (SUS) faz um enorme esforço institucional para implementar as determinações da Constituição de 1988 e da Lei Orgânica da Saúde, mas os passos são lentos, há uma resistência enorme, e parece que os resultados são ainda pouco significativos.

Enfim, a epidemia de AIDS que é um problema emergente nas últimas duas décadas, aparece dentro de um quadro extremamente difícil, e joga seu papel no agravamento da crise do setor saúde. O reconhecimento da existência do problema drogas como mais um problema para a saúde pública do país, sequer está plenamente compreendido e portanto a resposta do ponto de vista da saúde a ele, quando e onde existe, é bastante deficitária.

Não havendo como pensar em ações de saúde fora destes parâmetros, temos claro que estes fenômenos influenciam as possíveis ações para o enfrentamento de AIDS relacionada às drogas, o mesmo acontecendo no sentido inverso, AIDS e drogas agravam este complexo quadro de saúde no Brasil

Como informação adicional, em pesquisa do IBOPE e da Confederação Nacional da Indústria realizada em todo Brasil entre 24 e 28 de fevereiro de 2000 , os brasileiros consideram a saúde o segundo maior problema do Brasil (com 50\% das indicações dos entrevistados, contra $77 \%$ atribuídos ao desemprego). $\mathrm{Na}$ mesma pesquisa de opinião, as drogas aparecem em $3^{\circ}$ lugar com $39 \%$ das indicações (71).

A Organização Mundial da Saúde publicou, em junho de 2000, um ranking de qualidade de atenção à saúde na qual o Brasil foi considerado número 125 (72). Embora polêmico, o relatório dá uma boa noção de implicações da política econômica e social nas condições de atenção à saúde do povo brasileiro. 


\section{I.15 - AIDS entre Usuários de Drogas Injetáveis}

A epidemia de AIDS entre usuários de drogas injetáveis (UDIs) teve inicio muito semelhante à epidemia de AIDS em geral. Os primeiros casos registrados entre UDIs, foram na cidade de Nova Iorque ainda no início dos anos 80 . A epidemia neste segmento, que se localizava, principalmente, em alguns países europeus (França, Espanha, Itália, dentre outros) e em alguns dos estados dos Estados Unidos da América, disseminou-se rapidamente para os países em desenvolvimento na América

Latina, Ásia, Leste Europeu e mais recentemente para a África. Até o final de 1999 , eram 134 os países que reportaram o uso de drogas injetáveis em todo o mundo, dentre os quais, 114 notificaram à OMS casos de AIDS por esta via de transmissão (vide nota de rodapé da página 8).

A presença do uso de drogas injetáveis acrescentava uma nova característica à dramaticidade da epidemia em geral. Eram as explosões da taxas de soroprevalência de HIV em um curto período de tempo, assim que se identificava a presença do vírus nas populações de usuários de drogas injetáveis (UDIs). Em Bangkok, Tailândia, as taxas de soroprevalência entre usuários de drogas subiram de $2 \%$ para $40 \%$ em apenas dois anos (1986-1988). Em Manipur, na Índia, as taxas encontradas no início de 1989 subiram em apenas 3 meses de $0 \%$ para $9 \%$; e em apenas mais 3 meses, chegavam a $56 \%(1)$. Na cidade de Ukraniana e de Mykolayev, a prevalência observada era de $0 \%$ em 1994 e chegou a 57\% dois anos depois (73). O mesmo fenômeno foi encontrado em varias partes do mundo, relacionando sempre o uso de drogas injetável e uma rápida velocidade de disseminação do $\operatorname{HIV}(1,73)$.

Na duvida sobre a suficiência de estudos de prevalência seriados, pelo menos na Tailândia, e em outros países Asiáticos, foram realizados alguns estudos de incidência. Na Tailândia, onde as taxas foram de 4-8 casos por pessoas sob risco por ano, demonstrou-se que mesmo onde as taxas de incidência se estabilizaram em patamares elevados, a disseminação do HIV não arrefeceu. Em casos mais extremos deduziu-se que no Norte da Tailândia, na Birmânia, na China e no Nordeste da Índia, estas taxas chegam a 10-100 casos por pessoa sob risco por ano(74). 
O passo seguinte, foi perceber a conexão existente entre a disseminação na população de UDIs e sua influência nas curvas de crescimento de HIV na população geral, via seus parceiros sexuais e seus filhos.

No Brasil a disseminação da epidemia de HIV/AIDS entre UDIs, tem início no Estado de São Paulo em 1982, quando o primeiro caso nesta categoria de exposição foi notificado ao Ministério da Saúde. A epidemia neste segmento no Brasil, teve um incremento de mais de 3000 casos novos por ano desde 1993, perfazendo, até 31 de maio de 1997, um total de 22.879 casos. Esses casos representavam $20,6 \%$ do total acumulado de casos de AIDS notificados no País até a data acima referida (75). Embora com variações regionais, desde então esta proporção vem se mantendo na epidemia brasileira. No boletim epidemiológico da Coordenação Nacional de Doenças Sexualmente Transmissíveis e AIDS do Ministério da Saúde (CN DST/AIDS) de agosto de 2000, os UDIs representavam 19,3\% dos casos de AIDS do país desde o início da epidemia até aquela data (76).

No Estado de São Paulo, a epidemia de AIDS também cursou com uma grande influência do uso de drogas injetáveis. Dos 79.634 casos de AIDS do Estado reportados até o final de 1999, 21.746 (27,30\%), são atribuídos ao uso de drogas injetáveis. Ademais da infecção direta, 18,5\% das mulheres cujo fator de infecção foi notificado como transmissão heterossexual, são parceiras sexuais de usuários de drogas injetáveis (20). Este panorama, que já chegou a ser de $40 \%$ das mulheres em 1994 (77), é uma demonstração clara do papel dos usuários de drogas injetáveis na epidemia de AIDS por contato heterossexual no Estado de São Paulo, hoje a via de transmissão preponderante.

Dentro do Estado de São Paulo, a Região Metropolitana de Santos sempre desempenhou destacado papel na epidemia de HIV/AIDS. Santos liderou durante anos o ranking de números de casos de AIDS proporcionais à população do país. Durante certo tempo, em meados da década de 90, metade dos casos da cidade eram decorrentes do uso de drogas injetáveis. Em agosto de 2000, 5 cidades da região (Santos, São Vicente, Praia Grande, Cubatão e Guarujá), encontravam-se entre as 20 cidades que lideravam o ranking brasileiro de casos de AIDS proporcionais à população(76). Todas elas apresentam uma importante fração de casos associados ao uso de drogas injetáveis. 
A disseminação da epidemia de AIDS na população de usuários de drogas já foi bastante relacionada com as rotas escolhidas pelo tráfico para levar as drogas aos mercados da Europa e da América do Norte, sendo o Porto de Santos, uma das mais importantes portas de saída da droga da América Latina $(28,29)$. Esta questão será aprofundada, posteriormente, neste trabalho.

Desta forma, na história da epidemia de AIDS no Brasil, a região aqui analisada teve e tem grande importância. Compreender o que significa para a epidemia o que ocorreu na Região Metropolitana de Santos, é parte fundamental da compreensão da epidemia de AIDS em nosso país.

\section{I.16 - A Região Metropolitana de Santos}

A Região Metropolitana de Santos ocupa uma área geográfica de cerca de $2400 \mathrm{~km}^{2}$ no litoral do estado de São Paulo. Tem uma população de 1.474 .665 hab, segundo os dados preliminares do Censo do IBGE, de 2000. É composta de 9 municípios: Santos, São Vicente, Guarujá, Cubatão, Praia Grande, Itanhaém, Mongaguá, Peruíbe e Bertioga. Sua principal fonte econômica é o Porto de Santos, seja diretamente, ou por meio dos serviços terciários a ele ligados.

O Porto de Santos é considerado o maior terminal da América Latina e por ele sai do país uma enorme quantidade de mercadorias não controladas, dentre as quais as drogas ilícitas. A região que tem uma característica turística importante, triplica sua população em períodos de feriados prolongados e férias de verão. A esta intensa variação populacional também é atribuído um mercado consumidor importante, inclusive de drogas ilícitas.

A população estável é composta maioritariamente de jovens (cerca de $33 \%$ com idade inferior a 19 anos) e idosos, sendo que os adultos jovens deixam a região em busca de mercado de trabalho em outros centros. As taxas de desemprego na região são similares às da Grande São Paulo, e atingem cerca de $20 \%$ da população economicamente ativa. Os processos de privatizações da Companhia Siderúrgica Paulista (COSIPA) e do Porto de Santos, foram os principais motores das taxas de desemprego na região.

A cobertura de água encanada é quase $100 \%$ e a cobertura da rede de esgoto, embora variável entre as cidades, é considerada bastante boa. Os serviços de saúde 
são considerados bem organizados e 6 dos 9 Municípios têm Programas Municipais de DST/AIDS, bem como ONGs e outras entidades da sociedade civil envolvidas na luta contra a AIDS. Apesar do ineditismo das políticas públicas para conter a epidemia de HIV/AIDS entre UDIs na região, existem apenas dois Municípios (Santos e São Vicente) e uma ONG (IEPAS), que conduzem Programas de Redução de Danos. 


\section{II - Objetivo Geral}

Geral: Estudar a tendência da epidemia de HIV/AIDS e seus determinantes, entre os usuários de drogas injetáveis, durante a década de 1990, na Região Metropolitana de Santos.

\section{II.1 - Objetivos Específicos}

- Estimar as taxas de soroprevalência de HIV entre UDIs durante a década de 1990;

- Analisar os fatores de risco possivelmente relacionados à soroprevalência do HIV;

- Avaliar o impacto da transição do padrão de uso de drogas e das medidas de saúde pública na Epidemia de HIV/ADS entre usuários de drogas injetáveis;

- Identificar as tendências nos comportamentos de risco sexual e risco quanto ao uso de drogas, durante a década de 1990; 


\section{III - Métodos}

\section{III.1 - Informações sobre os Estudos Transversais que compõem este} trabalho

Estudo I: Estudo Multicêntrico coordenado pela Organização Mundial da Saúde (fase I) sobre Comportamento de Risco e soroprevalência de HIV entre UDIs, entre 1991 e 1992. Este estudo envolveu 13 cidades do mundo. Estudo do tipo transversal, entrevistou na RMS 220 UDIs. Foram também realizados exames sorológicos para hepatites $\mathrm{B}$ e $\mathrm{C}$ nos entrevistados.

Estudo II: Estudo Multicêntrico sobre o Comportamento de Risco e Soroprevalência de HIV entre UDIs, que envolveu 7 cidades brasileiras (de 4 regiões geográficas diferentes), chamado de Projeto Brasil, realizado entre 1994 e 1996. Estudo do tipo transversal, entrevistou na RMS 140 UDIs. Foram também realizados exames sorológicos para hepatites $B$ e $C$ nos entrevistados.

Estudo III: Estudo Multicêntrico coordenado pela Organização Mundial da Saúde (fase II) de Uso de Drogas e suas Conseqüências Adversas à Saúde particularmente a transmissão do HIV e das hepatites B e C., realizado em 1999. Este estudo (ainda em curso em alguns países) envolve 21 cidades de todo o mundo. Estudo do tipo transversal, entrevistou na RMS 108 UDIs.

Nos três casos os estudos analisaram fatores de comportamento de risco para a transmissão do HIV entre usuários de drogas injetáveis. Mediram ainda, as taxas de soroprevalência para o HIV.

O Quadro 1 abaixo resume as características principais dos 3 Estudos: 
Quadro 1 - Quadro Comparativo de Metodologia nos 3 estudos

\begin{tabular}{|c|c|c|c|}
\hline $\begin{array}{ll}\text { Característica } & \text { Estudo } \\
\end{array}$ & Estudo I & Estudo II & Estudo III \\
\hline População estudada ( $\mathrm{N}$ de UDIs) & 220 & 140 & 108 \\
\hline Ano no campo & $91 / 92$ & 94/96 & 99 \\
\hline Título & WHO I & $\begin{array}{c}\text { Projeto } \\
\text { Brasil }\end{array}$ & WHO II \\
\hline Questionário & Anexo 1 & Anexo 2 & Anexo 3 \\
\hline Metodologia & Transversal & Transversal & Transversal \\
\hline Tipo de amostragem & Bola de Neve & Bola de Neve & Bola de Neve \\
\hline
\end{tabular}

\section{III.1.2 - Tipo de Estudo Desenvolvido Neste Trabalho}

Repetição de Estudos Comportamentais Transversais: (Repeated Behavioral Surveys) - Definido como uma repetição de estudos transversais, que analisa populações de difícil acesso similares em períodos diferentes, sem que os indivíduos incluídos nos estudos sejam necessariamente os mesmos $(78,79)$.

\section{III.2 - Amostras Estudos I, II e III}

A epidemia de AIDS trouxe para a Epidemiologia alguns novos desafios. Fenômenos importantes precisavam ser estudados e não se encaixavam na proposta tradicional de seleção de indivíduos com amostra probabilística. Como por exemplo estudar as populações escondidas como homens que fazem sexo com homens; profissionais do sexo sem ponto fixo, ou usuários de drogas injetáveis? Comportamentos escondidos, muitas das vezes criminalizados, não poderiam ser randomizados como em um inquérito domiciliar ou em um estudo desenvolvido com clientes de um serviço de saúde.

Desta forma a saída para constituição amostral encontrada nestes Estudos e que foi implementada entre usuários de drogas injetáveis de maneira mais abrangente pela primeira vez no Estudo Multicêntrico da OMS, fase I (o primeiro dos wès Estudos aqui mencionados), foi a da utilização da metodologia de "amostragem em 
cadeia" ou "chaim sampling". Dentro desta metodologia, utilizamos nos três Estudos aqui mencionados a técnica de recrutamento em "bola de neve" ou técnica de indicação sucessiva de entrevistas (80-82).

As limitações desta metodologia são exploradas em tópico a parte.

Ainda restava uma questão importante na formulação de um estudo de tendências. Como em uma população deste tipo, tão difícil de acessar, poderia se estudar tendência? A Organização Mundial da Saúde e o Programa de AIDS das Nações Unidas (UNAIDS) preconizam o uso de repetidos estudos transversais em populações deste tipo para fazer estimativas de tendência(79, 83). Amplamente utilizadas em termos de taxas de soroprevalência em estudos do tipo sentinela para monitorar a epidemia de HIV em diversas populações, a técnica de coleta de informações em populações similares, foi depois estendida para estes estudos comportamentais. Os estudos comportamentais repetidos foram utilizados para suprir esta dificuldade. Estes estudos são chamados também de "Repeated Behavioral Surveys in Populations at Risk of HIV" (78). Estas populações comparáveis, seguiram os mesmos critérios de recrutamento, foram estudadas com instrumentos similares, e representam um segmento muito semelhante aos usuários de drogas injetáveis em seus respectivos locais de estudo. A informação individual de cada entrevistado, passa a ser analisada como uma opinião coletiva de um segmento.

No caso dos três estudos aqui comparados, os critérios de inclusão foram:

- ser maior de 16 anos de idade (lembrando que nos estudos I e II o parâmetro foi estabelecido antes da norma do Conselho Nacional de Ética em Pesquisa de 1996);

- após ser esclarecido sobre o estudo, ter condições de assinar um consentimento informado, e no caso do Estudo III, menores de 18 anos terem os pais assinando o consentimento;

- ter feito uso de drogas injetáveis nos 6 meses anteriores à data da entrevista

O número de usuários de drogas injetáveis entrevistados foi o seguinte:

Estudo I: 220 entrevistas em usuários de drogas injetáveis (UDIs)

Estudo II: 140 entrevistas em UDIs.

Estudo III: 108 entrevistas UDIs 
O estudo III teve a particularidade de também estudar 100 ex-UDIs e 192 usuários que nunca injetaram drogas - NUDIs, que não serão objeto da corrente análise. Para o Estudo III, foram considerados ex-usuários de drogas injetáveis, aqueles que utilizaram droga injetável em vida, mas não o fizeram nos últimos 6 meses; e foram considerados não usuários de drogas injetáveis (NUDIs), aqueles que nunca utilizaram droga injetável, e que utilizam drogas que potencialmente poderão vir a ser utilizadas pela via injetável.

\section{III.2.1 - Limitações da Metodologia}

Existem numerosas dificuldades de realização de um Estudo quantitativo em populações de usuários de drogas injetáveis. A mais importante destas dificuldades foi bem pontuada por Bastos, FI (84) e é a definição do que seria de fato o universo em estudo.

Esta dificuldade é em muito agravada pela condição marginal que o usuário de drogas enfrenta nas circunstâncias de nossos estudos, onde seu comportamento além de não aceito socialmente, é considerado ilegal, como mencionado anteriormente.

Portanto torna-se inexequível a proposta clássica de randomizar a amostra. A alternativa encontrada de amostragem em cadeia, embora não seja ideal, é a alternativa a não estudar o fenômeno.

As limitações desta metodologia são conhecidas dos epidemiologistas e se traduzem sobretudo na perda do poder de generalização dos achados (85). Lopes e colaboradores estudaram em nosso meio a aplicação da técnica de recrutamento de "bola de neve" e não encontraram desvio de seleção em amostras de um estudo caso controle, exatamente entre usuários de drogas (82).

No caso específico da Região Metropolitana de Santos alguns fatores contribuíram para diminuir estas limitações. O primeiro foi que a maioria absoluta das amostras foi de rua, em contraposição à amostras de centros de tratamento de dependência de drogas. Esta característica de forma alguma elimina os desvios, mas diminui o fator de confusão relativo a pensar usuário de drogas apenas como dependente. O segundo, foi um empenho determinado no segundo e terceiro estudos, de inserir questões relativas às redes de interação sociais dos usuários de drogas 
injetáveis, ampliando a conotação do comportamento em estudo do indivíduo para o seu meio. Esta técnica, que mistura metodologias quantitativas e qualitativas, vem sendo aplicada com sucesso por alguns pesquisadores com o sentido de aplacar os possíveis desvios que amostras do tipo bola de neve podem gerar $(86,87)$. No entanto os dados colhidos acerca da rede social dos entrevistados não serão analisados neste trabalho especificamente, por terem sido aplicados apenas aos questionários dos estudos II e III, e lamentavelmente não serem comparáveis nos 3 estudos.

Outra limitação importante é a de considerar o estudo em populações de indivíduos diferentes entrevistados ao longo do tempo como um estudo de tendência. Esta limitação encontra explicação similar à da constituição da amostra, em virtude da dificuldade de acesso a esta população específica. Embora não seja uma alternativa clássica da estatística, este mesmo formato tem sido utilizado por autores que trabalham com AIDS entre usuários de drogas em todo o mundo, e aceito em todas as publicações científicas de primeira grandeza, como já exemplificado neste trabalho(78, 79, 88, 89). Mesmo entidades responsáveis pelo monitoramento da epidemia no Brasil e no mundo, como a UNAIDS e a OMS, utilizam-se de instrumentos similares para estudar tendências de soroprevalência e de comportamento, como já analisamos anteriormente.

A última e não menos importante limitação deste formato de estudo é que, exceto pela sorologia de HIV, todas as outras informações aqui valoradas, são auto reportadas pelos entrevistados. Embora possa se considerar aí uma nova fonte de vícios na análise, sobretudo por aquilo que é socialmente desejável nas respostas, estudos de outros pesquisadores também demonstram a confiabilidade de informações auto-reportadas de usuários de drogas (90).

\section{III.3 - Coletas dos Dados}

Nos três estudos, os entrevistados foram recrutados nas ruas ou em locais de tratamento. Nas ruas os primeiros contatos foram realizados pelos agentes "redutores de danos" que têm um trabalho de educação continuada com parte da população alvo envolvida. A partir de então, cada entrevistado referia novas pessoas para entrevistas, de sua rede social de relacionamento. As entrevistas foram realizadas em locais da 
maior diversidade possível como: casas de usuários de drogas, casas de traficantes, casas de prostituição, unidades moveis (veículos), praças e outros logradouros públicos, clínicas de tratamento de drogas, unidades básicas de saúde, dentre outras.

Os entrevistados nos três Estudos, receberam reembolso por suas despesas referentes à alimentação e transporte, que sempre giraram em torno do equivalente em moeda nacional a cada época a 3 dólares americanos, sendo que no último estudo, esta quantia chegou a ser equivalente a 10 dólares americanos. Todas as entrevistas foram realizadas por técnicos de nível universitário, ou alunos dos dois últimos anos de cursos de Psicologia, Serviço Social e Medicina.

Os participantes do Estudo responderam a um dos questionários padrão (anexos I, II e III) utilizados nos respectivos Estudos Multicêntricos a saber: Estudo Multicêntrico da OMS fase I (Estudo I); Projeto Brasil (Estudo II); e Estudo Muticêntrico da OMS, fase II (Estudo III). Os critérios para analisar as informações obtidas dos questionários serão destacados no item VIII.6.1 deste trabalho (variáveis analisadas). Os referidos questionários foram divididos em seções contendo:

- Dados demográficos;

- Hábitos em relação ao uso de drogas injetáveis;

- Compartilhamento de agulhas e seringas;

- Comportamento sexual;

- Conhecimento sobre AIDS e consequiente mudança de comportamento;

- História de prisões;

- História de viagens (se o entrevistado ia de uma cidade à outra com freqüência);

- História de testes prévios para HIV e para Hepatites B e C.

No anexo III (Estudo III) ainda contamos com as seguintes seções:

- questões específicas para quem nunca injetou, ou para quem deixou de injetar há mais de 6 meses (vide detalhes no próprio anexo III)

- Uso de drogas antes da primeira injeção (só para UDIs)

- Overdoses (todos os entrevistados)

- hepatites (todos os entrevistados)

- Função da droga - relativo à tráfico (todos os entrevistados)

- Histórico médico (todos os entrevistados) 
- Utilização dos Serviços de Saúde (todos os entrevistados)

- Violência (todos os entrevistados)

A inclusão das informações destas novas seções no Estudo III, mostraram-se acertadas, embora não sejam motivos de análise mais detalhada neste trabalho, por não serem comparáveis aos Estudos I e II.

Após as entrevistas os indivíduos foram submetidos à coleta de 10 a $20 \mathrm{ml}$ de sangue, feitas no mesmo local das entrevistas por auxiliares de enfermagem. $O$ sangue foi centrifugado e o soro congelado a menos $20^{\circ} \mathrm{C}$. Foram então efetuadas sorologias de HIV e hepatites B e C (nos 780 entrevistados). Dentre o total de pessoas testadas nos 3 estudos, incluem-se os 468 indivíduos analisados nesta tese.

\section{III.4 - Técnicas Laboratoriais}

As técnicas laboratoriais e os serviços utilizados para o teste dos soros foram:

Estudo I: Laboratório de Referência - Hemocentro de Santos, vinculado à Secretaria do Estado da Saúde de São Paulo.

Os soros foram testados pela técnica de ELISA para anti-HIV ( 1 ou 2) do laboratório ABBOTT, e os com resultado positivo, confirmados com imunoblot da EMBRABIO LTD.

Para hepatites foram utilizadas as técnicas de ELISA: para HbsAg, anticorpos anti-HCV (segunda geração) e Anti-HBcAg, do laboratório ABBOTT.

O profissional responsável pelos exames laboratoriais, foi o Dr. Milton Arthur Ruiz.

Estudo II: Laboratório de Referência: Laboratório da Disciplina de Informática Médica da Faculdade de Medicina da USP.

Os soros foram testados pela técnica de ELISA para anti-HIV (1 ou 2) do laboratório ABBOTT, e os com resultado positivo, confirmados com imunoblot da EMBRABIO LTD.

Os testes para hepatites B (HBs Ag e Anti $\mathrm{HBc} \mathrm{Ag}$ ) foram feitos por técnica de ELISA utilizando-se de kits do laboratório ABBOTT. 
Os testes de hepatite $\mathrm{C}$ foram realizados com a técnica de ELISA utilizando-se kits do laboratório EMBRABIO.

O profissional responsável pelos exames laboratoriais, foi o Dr. Raymundo Soares de Azevedo Neto.

Estudo III: Laboratório de Referência: Laboratório Central da Secretaria da Saúde do Município de São Vicente.

Os soros foram testados para HIV por duas técnicas: Hemoaglutinação (Laboratório Fujerebio) e Elisa (Laboratório Organon Teknika).

Os testes para hepatites B (HBs Ag e Anti HBc Ag) foram feitas por técnica de ELISA utilizando-se kits do laboratório Sanofi Pasteur.

Os testes de hepatite $\mathrm{C}$ foram realizados com a técnica de ELISA utilizando-se kits do laboratório EMBRABIO.

O profissional responsável pelos exames laboratoriais, foi o Dr. Edmir Boturão Neto.

\section{III.5 - Análise Estatística:}

Os dados obtidos foram armazenados em 3 bancos de dados distintos do software Epiinfo 6.04 (atualizados para a versão C), e sistematizados em um banco de dados único do software SAS (System Viewer versão 6.12 para Windows), de onde saíram a maioria das análises bivariadas e multivariadas. As análises bivariadas foram conduzidas utilizando-se do teste do qui-quadrado; qui-quadrado para tendência linear de Mantel-Haenszel; teste de Fisher e teste t de Student. Foi definido um valor de nível de significância $\alpha=0.05$, para um intervalo de confiança de $95 \%$. As análises multivariadas foram conduzidas utilizando-se de regressão logística (stepwise retrógrada). Nela foram utilizados as diversas variáveis que estão a seguir detalhadas e que eventualmente poderiam ter associação com a transmissão do HIV. As análises univariadas do Estudo III referentes aos aspectos singulares do Estudo III (sobretudo hepatites e overdoses), foram conduzidas em Epiinfo 6.04. 


\section{III.5.1 - Variáveis Analisadas}

Será dado destaque ao que foi considerado nas análises realizadas neste estudo comparativo. Os três questionários foram extensos: cada um com 10 a 16 seções, com numerosas questões em cada uma - num total máximo de 275 questões no último dos questionários. Os entrevistados respondiam a cerca de 120 questões por questionário. E portanto, serão mencionadas a seguir, quais variáveis fazem parte da presente análise, e como elas foram agregadas para efeito de comparação. Todas estas informações são relativas ao que é comparável nos 3 Estudos: os usuários de drogas injetáveis.

- As seguintes variáveis demográficas foram consideradas:

Idade: foram considerados as informações referidas pelos entrevistados na data da entrevista, menos o dia, mês e ano de nascimento dos entrevistados nos três estudos. O resultado foi agrupado em três categorias: abaixo de 25 anos; entre 25 e 40 anos; e acima de 40 anos de idade.

Sexo: considerados masculino e feminino. Havia a opção de transexual, que em nenhum dos três estudos foi encontrado.

Escolaridade: foram considerados aqui anos completos de instrução. Foram agrupados em menos de 9 anos de instrução (ou primeiro grau completo); entre 9 e 12 anos (segundo grau completo) e acima de 12 anos de instrução, com nível universitário (completo ou não).

Relação com o Mercado de Trabalho: embora existissem várias opções de resposta (de 7 a 12 alternativas, dependendo do Estudo em questão), mas que foram agrupados em formal (com vínculo formal com o mercado de trabalho), informal (sem vínculo formal com o mercado) e ilegal (furtos, roubos, prostituição, dentre outros).

Histórico de Prisões: haviam várias questões relacionadas à prisão desde que iniciou o uso de drogas nos três questionários. Optou-se por utilizar para a análise o que era comparável nos três estudos: se alguma vez, desde então, o entrevistado havia sido preso.

Morador da Cidade de Santos: As entrevistas foram feitas de maneila a perguntar ao entrevistado qual a sua cidade de moradia atual. As opções oferecidas foram as 9 cidades da Região Metropolitana de Santos, o Estado de São Paulo e 
outras cidades do Brasil e do mundo. Para efeito de análise, foram consolidados dois blocos: Santos e qualquer outra cidade. Todas as entrevistas foram conduzidas na RMS.

- No que tange ao uso de drogas foram consideradas:

Droga mais utilizada: perguntado qual a droga utilizada (injetável e não injetável), e qual a frequência de seu uso. Para a análise, foi considerada a droga injetável mais freqüentemente utilizada.

Compartilhamento de agulhas e seringas: há duas possibilidades de compartilhamento. Receber ou dar seringas utilizadas. Nesta variável foi considerado compartilhamento quem referiu ter utilizado seringas e agulhas já usadas por outra pessoa (portanto receber).

Nas frequiências do uso de drogas injetáveis os três questionários perguntaram sobre frequiência de uso no mês (quantos dias do último mês você injetou) e uso no dia (quantas vezes você injeta em um dia típico). Dia típico é definido junto ao entrevistado como sendo um dia de uso mais ou menos padrão para aquele usuário. Exemplo: se o usuário injeta em média 3 vezes por dia, mas em um sábado em uma festa injetou 10 vezes, a frequiência em um dia típico é 3 e não 10.

O consumo de crack foi definido por uso da droga (cocaína em forma de pedra fumada). O uso de crack injetável, não foi considerado na análise, embora tenha sido reportado em pequena escala, sobretudo no Estudo III.

A fonte de seringas novas mais freqüente nos três estudos foi a farmácia. Nos três estudos foi perguntado sobre os programas de "outreach work" e de trocas de seringas como fontes de fornecimento de seringas novas. As perguntas foram feitas desta maneira, por serem aplicáveis em outros centros dos respectivos estudos multicêntricos (por exemplo em Sidney existiam programas desta natureza desde 1987). Para análise dos dados da Região Metropolitana de Santos no entanto, consideramos a resposta "outreach work" para os Estudos II e III; e troca de seringas para o Estudo III. Esta decisão foi pautada na não existência destes programas anteriormente na região o que, "a priori", inviabilizaria uma resposta afirmativa.

- No que se refere às variáveis de práticas sexuais foram consideradas: 
Relacionamento sexual utilizando-se preservativo com parceiros sexuais principais (estes são definidos como pessoas com as quais se mantém relacionamento “estável” há pelo menos 6 meses), que podem ser mais de um simultaneamente.

Relacionamento sexual utilizando-se preservativo com parceiros sexuais ocasionais (que são definidos como pessoas com as quais manteve relações sexuais esporadicamente, sem compromisso).

Relacionamento sexual utilizando-se preservativo com parceiros sexuais considerados clientes (que são definidos como pessoas com as quais se faz sexo em troco de dinheiro ou drogas).

O uso de preservativos foi classificado em: sempre, na maioria das vezes, esporadicamente e nunca. $\mathrm{Na}$ análise, foram agrupados em sempre (100\%) - única forma protegida de ter relacionamento sexual; ou não sempre - qualquer outra forma de relação protegida em menos de $100 \%$ das vezes.

- O conhecimento sobre HIV/AIDS foi analisado como se segue:

Embora existissem numerosas questões sobre conhecimento e testagem, na análise, foi considerada apenas a resposta SIM ou NÃO para o entrevistado que tomou alguma providência para modificar seu comportamento após ter conhecimento sobre o HIV e AIDS,.

- Testes sorológicos:

Foram considerados positivos para HIV os reagentes a pelo menos duas técnicas distintas de HIV (dois ELISAs pelo menos). Foram considerados positivos para hepatite B os reagentes a pelo menos um dos exames de hepatite B (HBs Ag ou Anti $\mathrm{HBc} \mathrm{Ag}$ ). Foram considerados positivos para hepatite $\mathrm{C}$ os reagentes ao exame de ELISA de hepatite C. Os detalhes adicionais sobre testes laboratoriais estão descritos no item Técnicas Laboratoriais.

- As variáveis de conhecimento sobre hepatites (variáveis incluídas somente no Estudo III):

O Estudo buscou informações sobre conhecimento que os entrevistados tinham sobre hepatites dos tipos B, C e outros tipos de hepatites. Traçou também um 
perfil de vacinação de hepatite $B$, buscando informações sobre acesso, quantidade de doses e disposição do entrevistado para o uso da vacina. Foram ainda analisadas questões que respondiam à informação básica sobre qualquer das formas de hepatites.

- As variáveis sobre overdose foram (variáveis também somente incluídas no Estudo III):

Overdose foi definida como uma situação de efeitos colaterais importantes de utilização de drogas, que culminou com perda da consciência.

Foi dado destaque às informações sobre se o entrevistado havia experimentado uma overdose, ou testemunhado uma. No caso do entrevistado ter tido uma overdose, se ele foi ou não socorrido e por quem. Na questão de o entrevistado ter sido testemunha desta situação foi perguntado se a overdose foi ou não fatal, se o entrevistado tomou providências, e que providências foram estas. Para análise, foram excluídos os entrevistados que admitiram uso injetável de heroína nos últimos 6 meses, para se ter um quadro mais claro de overdose entre usuários de cocaína.

\section{III.6 - Considerações Éticas}

Os Estudos tiveram, cada um a sua época, aprovação dos Conselhos de Ética da Universidade da Califórnia Berkeley e San Francisco (I); da Secretaria de Higiene e Saúde de Santos (II); do Hospital das Clínicas da Faculdade de Medicina da USP (III).

Os formulários de consentimentos informados (anexos) foram elaborados com o padrão da OMS, adaptados à nossa realidade.

Foram oferecidos os resultado dos testes de HIV e de hepatites em todos os Estudos para todos os entrevistados. Embora não tenham sido computados (por não serem objetos de estudo), os índices de procura por resultados foram bastante baixos, não chegando a um quinto do total de entrevistados (nos três casos).

Durante todos os Estudos foram oferecidos aos que vieram em busca de seus resultados, ou aos que em outro momento apresentavam demandas de saúde, a possibilidade de serem encaminhados aos serviços de saúde do Sistema Único de 
Saúde regional, de acordo com local de moradia e/ou queixa ou diagnóstico apresentado. 


\section{IV - Resultados}

\section{IV.1 - Dados Demográficos}

Como a maioria dos resultados que interessam ao estudo estão relacionados aos usuários de drogas injetáveis e somando-se o fato de que esta é a única categoria do estudo possível de comparação nas três fases do mesmo, as informações aqui detalhadas, referem-se aos usuários de drogas injetáveis dos 3 estudos $(n=468)$. Algumas informações relevantes encontradas especificamente no estudo III ( $n=400$ dos quais 108 UDIs), sobretudo no caso de hepatites e overdoses, são mencionadas também ao final deste capítulo pelo seu ineditismo e relevância quando tratamos das consequiencias para a saúde do uso indevido de drogas. Todos os participantes responderam ao questionário e colheram material para a sorologia de HIV.

A amostra $(n=468)$ é composta de $70 \%$ de homens e $30 \%$ de mulheres. Quanto à idade, 22\% tem menos de 25 anos de idade, a grande maioria concentra-se entre 25 e 40 anos (65\% do total) e apenas $13 \%$ tem mais de 40 anos de idade.

O nível de escolaridade das pessoas participantes da mostra, aponta para $84 \%$ com 8 anos ou menos de educação formal, $13 \%$ entre 9 e 12 anos e apenas $3 \%$ com mais de 12 anos de escolaridade.

Quanto à situação de emprego nos seis meses anteriores à entrevista, 17\% tinha emprego formal, $56 \%$ se relacionava informalmente com o mercado de trabalho e $27 \%$ subsistia de atividades ilegais.

A situação de prisão é um dado relevante entre os usuários de drogas injetáveis por inúmeros motivos: propicia sexo entre pessoas do mesmo sexo; uso de drogas em condições de higiene inadequada e equipamentos compartilhados; violência sobre o usuário, dentre outras. De toda amostra, $59 \%$ já estivera preso pelo menos uma vez depois de iniciar as atividades com drogas.

Quanto ao local de moradia: no Estudo I, 79\% morava em Santos e 21\% nas outras cidades da região; no Estudo II, $75 \%$ em Santos e $25 \%$ em outras cidades da região e no Estudo III, $30 \%$ moravam em Santos e $70 \%$ em outras cidades da região. Apenas no Estudo III foi perguntado em que cidade utilizou drogas injetáveis pela primeira vez, e 50\% referiu ter feito o primeiro uso de drogas injetáveis em S.intos. Os resultados referentes às variáveis demográficas estão resumidos na Tabela 1 abaixo 
Tabela 1-Características Demográficas dos Usuários de Drogas Injetáveis da Região Metropolitana de Santos $(\mathrm{N}=468)$

\begin{tabular}{|c|c|c|c|c|c|}
\hline Característica & & $\begin{array}{c}\text { Estudo I } \\
(1992-1993) \\
n=220 \\
\%\end{array}$ & $\begin{array}{c}\text { Estudo II } \\
(1994-1996) \\
n=140 \\
\%\end{array}$ & $\begin{array}{c}\text { Estudo III } \\
\begin{array}{c}(1999) \\
n=108 \\
\%\end{array}\end{array}$ & $\begin{array}{l}\text { Valor } \\
\text { de } p^{*}\end{array}$ \\
\hline \multirow{2}{*}{ Sexo } & Mulheres & 42 & 20 & 21 & \multirow[t]{2}{*}{$<0.0001$} \\
\hline & Homens & 58 & 80 & 79 & \\
\hline \multirow{3}{*}{ Idade } & Abaixo de 25 anos & 29 & 14 & 17 & \multirow[t]{3}{*}{$<0.0001$} \\
\hline & Entre 25 e 40 anos & 62 & 70 & 63 & \\
\hline & Acima de 40 anos & 9 & 15 & 20 & \\
\hline \multirow{3}{*}{$\begin{array}{l}\text { Anos de } \\
\text { Educação }\end{array}$} & Até 9 anos & 84 & 80 & 89 & \multirow[t]{3}{*}{0.3035} \\
\hline & 9 a 12 anos & 12 & 17 & 10 & \\
\hline & Acima de 12 anos & 3 & 3 & 1 & \\
\hline \multirow{2}{*}{$\begin{array}{l}\text { Local de } \\
\text { Recrutamento }\end{array}$} & Cidade de Santos & 79 & 75 & 30 & \multirow[t]{2}{*}{$<0.0001$} \\
\hline & $\begin{array}{l}\text { Outra cidade da } \\
\text { RMS }\end{array}$ & 21 & 25 & 70 & \\
\hline \multirow{3}{*}{$\begin{array}{l}\text { Vínculo de } \\
\text { Emprego }\end{array}$} & Formal & 19 & 16 & 14 & \multirow[t]{3}{*}{0.0004} \\
\hline & Informal & 36 & 72 & 71 & \\
\hline & Ilegal & 45 & 12 & 15 & \\
\hline
\end{tabular}

* Mantel Haenszel $\chi^{2}$

\section{IV.2 - Como é o Uso de Drogas}

A principal droga utilizada para injeção na década de 90 foi a cocaína, dentre os entrevistados deste estudo. No Estudo I, 95\% usava cocaína como droga de eleição; no Estudo II 94\% e no Estudo III 95\%. Várias drogas também utilizadas de maneira injetável foram referidas, tais como anfetaminas, tranqüilizantes, barbitúricos, heroína, o próprio crack, dentre outras, mas todas têm menor frequiência de uso.

O compartilhamento de seringas e agulhas que pode ser visto no Gráfico I abaixo, teve um pequeno aumento do primeiro para o segundo Estudo, e uma acentuada queda em 1999 (respectivamente 55\%; 70\% e 24\%).

Ainda quanto à forma de consumir a droga injetável há uma diminuição acentuada com o passar dos anos do Estudo, tanto na frequiência de uso em dias no 
mês (uso diário caindo de $32 \%, 28 \%$ e $13 \%$ respectivamente), quanto na freqüência de uso em um mesmo dia (mais de $5 \mathrm{x}$ ao dia caindo respectivamente de $42 \%$; 30 e $15 \%)$ (Gráfico I).

Há ainda um acentuado aumento do consumo de cocaína em forma de pedras de crack para uso fumado, no decorrer da década de 90 , entre UDIs (10\%; $60 \%$ e $67 \%$ respectivamente). Esta tendência de expansão do uso de crack, é verificada em todo Brasil, e particularmente no Estado de São Paulo, durante a década estudada $(45,52,65,67,68)$. A relação entre o padrão de consumo de drogas e a infecção pelo HIV será explicitada adiante na seção de análises bivariadas.

\section{Gráfico I}

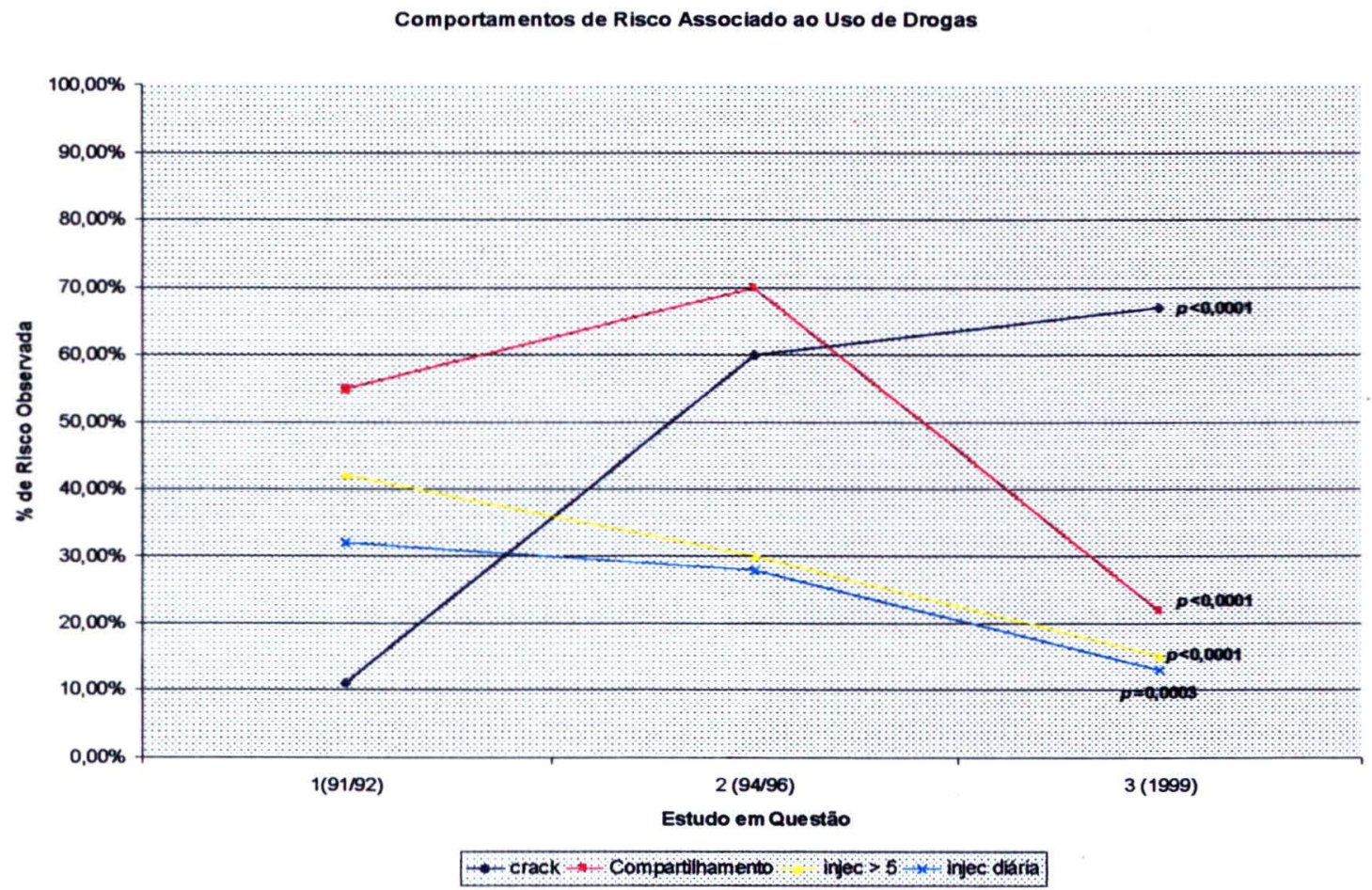

\section{IV.3 - Comportamento Sexual}

O comportamento sexual dos indivíduos entrevistados nos três estudos nã teve uma variação expressiva como um todo, durante a década de 1990. Há, no entanto, um ponto de variação: o número de homens que tiveram sexo com outros homens. Esta variação oscilou no tempo, saindo de $16 \%$ no Estudo I; indo a $33 \%$ no Estudo II e voltando a $11 \%$ no Estudo III, mas teve significância estatística $(\mathrm{p}<0.001)$. Outra variação, a do número de entrevistados que tiveram relacionamento sexual desprotegido com seus parceiros sexuais principais ( $35 \%$ nos estudos I e II e 
49\% no Estudo III ( $\mathrm{p}=0.06$ ), aponta portanto para uma discreta piora no decorrer do tempo, sem no entanto apresentar significância estatística. Para efeito de análise, foi considerado protegido quem teve $100 \%$ das relações sexuais utilizando-se de preservativos (masculinos ou femininos) - (tabela 2 abaixo).

Embora tenham havido pequenas alterações no comportamento dos que tiveram relacionamento sexual desprotegido com parceiros considerados ocasionais $(27 \%, 25 \%$ e $20 \%$ respectivamente) ou clientes $(14 \%, 17 \%$ e $7 \%$ respectivamente); estas mudanças também não foram estatisticamente significantes (tabela 2).

Tabela 2 - Distribuição percentual do uso de preservativos na totalidade das relações sexuais, segundo tipo de parceiros sexuais, entre UDIs, Região Metropolitana de Santos, 1991-1999.

\begin{tabular}{|c|c|c|c|c|}
\hline Parceiro & I & II & III & valor de $\mathrm{p}^{*}$ \\
\hline Principal & $65 \%$ & $65 \%$ & $51 \%$ & 0,06 \\
\hline Ocasional & $73 \%$ & $75 \%$ & $80 \%$ & 0,45 \\
\hline Cliente & $86 \%$ & $83 \%$ & $93 \%$ & 0,65 \\
\hline
\end{tabular}

${ }^{*}$ Mantel Haenszel $\chi^{2}$

\section{IV.4 - Mudanças de Comportamento Influenciadas pelo Conhecimento de HIV/AIDS}

Outra variável analisada foi se o entrevistado mudou seu comportamento a partir do conhecimento sobre a existência da epidemia de AIDS. Suas respostas, sem qualificá-las, eram em relação a aumentar a segurança para evitar infecção. A mudança de comportamento ocorreu paulatinamente, demonstrando uma preocupação ascendente dos UDIs estudados. Em 1991/1992, 51\% haviam reportado ter aumentado suas precauções depois de conhecer a epidemia de AIDS; em 1994/1996 esta proporção aumentou para 55\% dos entrevistados, chegando em 1999 aos $72 \%$ dos entrevistados havendo mudado comportamento sob a influência dos conhecimentos adquiridos sobre a epidemia de AIDS. 


\section{IV.5 - Prevalência do HIV e de outras doenças}

As taxas de soroprevalência de HIV foram respectivamente: $63 \%, 65 \%$ e $42 \%$ nos Estudos I, II e III (Tabela 3 abaixo).

As taxas de prevalência de hepatite $B$ encontradas foram de $75 \%$ para o Estudo I, para $71 \%$ no Estudo II e $51 \%$ para o Estudo III (Tabela 3).

Quanto às taxas de prevalência de hepatite $\mathrm{C}$ encontradas, foram de $75 \%$ para o Estudo I, 77\% no Estudo II e 44\% para o Estudo III (Tabela 3).

As taxas de hepatites apresentadas, embora não sejam objeto de comparação deste trabalho, podem ser vistas como um marcador biológico adicional de tendência de infecções parenterais entre usuários de drogas injetáveis, no mesmo local e período estudados.

Tabela 3 - Taxas de Soroprevalência de HIV, hepatite B e hepatite C entre UDIs encontradas segundo estudo, RMS

\begin{tabular}{lccl}
\hline Taxas de & I & II & III \\
Soroprevalência & & & \\
\hline HIV & $63 \%$ & $65 \%$ & $42 \%$ \\
HepB & $75 \%$ & $71 \%$ & $51 \%$ \\
HepC & $75 \%$ & $77 \%$ & $44 \%$ \\
\hline
\end{tabular}

No Gráfico II podemos visualizar melhor a tendência de queda das taxas de soroprevalência dos diversos patógenos de veiculação sangüínea ocorridas na década de 90 entre UDIs na amostra estudada. 
Gráfico II

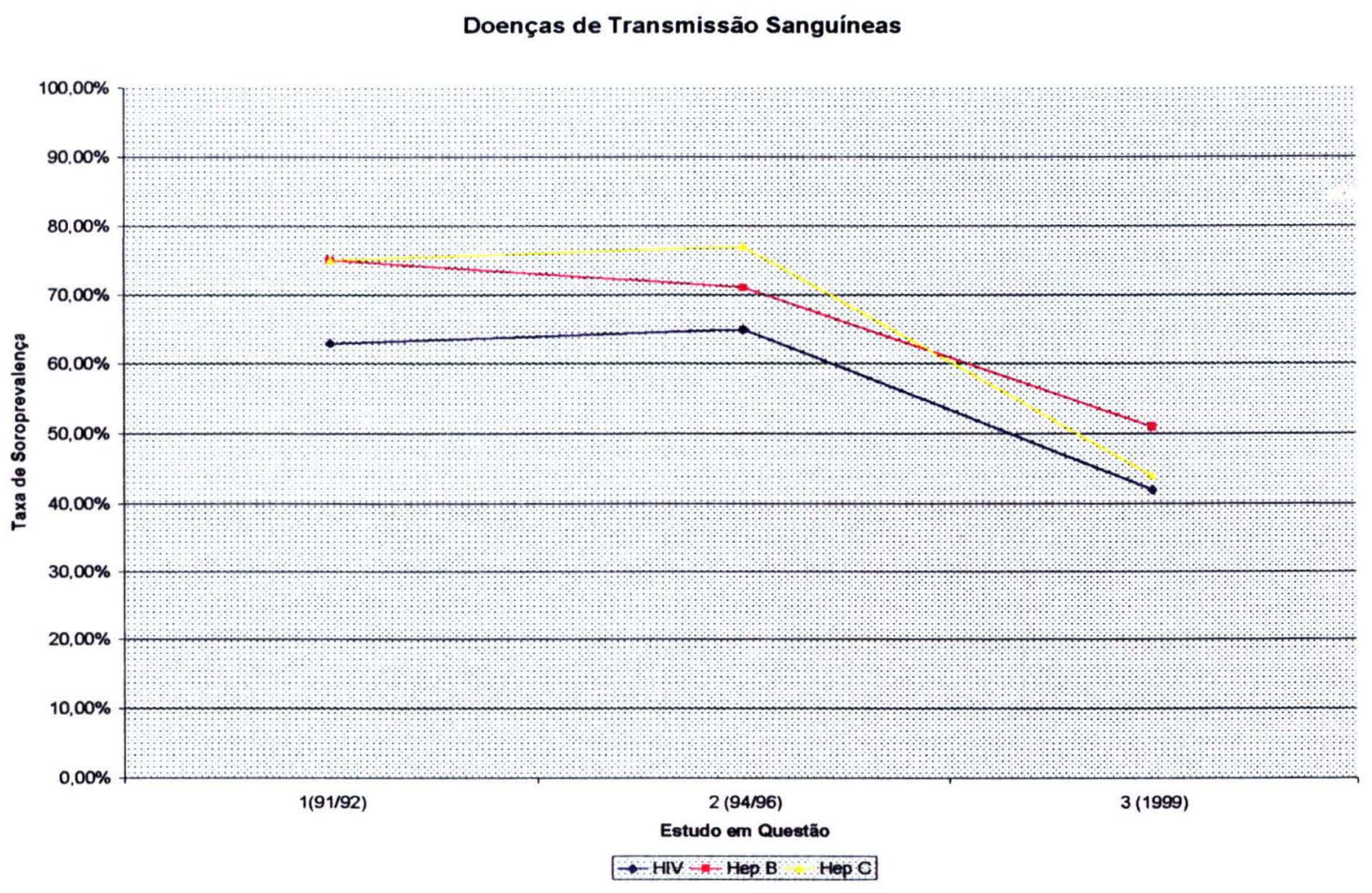




\section{IV.6 - Análise dos Fatores de Risco para HIV}

\section{IV.6.1 - Análise Bivariada}

Para as análises bivariadas, utilizamos as variáveis que poderiam estar associadas como fatores de risco para a infecção pelo HIV. Esta análise foi estratificada para estas variáveis pelo possível efeito que poderiam exercer sobre o risco de infecção. Foram portanto utilizados: sexo; idade; nível de escolaridade; categoria de trabalho; morador ou não na cidade de Santos; se esteve alguma vez na prisão (ou nunca foi preso); os próprios estudos como variáveis; usuário de crack nos últimos seis meses (ou não usuário de crack); compartilhamento de agulhas e seringas (ou usuário de equipamentos individuais de injeção); usuário de drogas injetáveis diariamente (ou usuário de drogas injetáveis com qualquer outra freqüência); usuário de drogas injetáveis com mais de cinco aplicações por dia (contra de 3 a 5 injeções por dia; e de 0 a 2 injeções por dia), além de anos de uso de droga injetável. A Tabela 4 abaixo, demonstra em detalhe os resultados que apresentaram alguma relevância para a análise.

Como pudemos verificar na análise bivariada os fatores que se expressaram como associados à infecção pelo HIV foram: ser mulher usuária de drogas injetáveis; compartilhar seringas; usar drogas injetáveis diariamente; usar drogas injetáveis mais de cinco vezes por dia; e ser morador da cidade de Santos. Embora tivéssemos aproveitado na análise multivariada, os fatores de risco uso de crack e ter sido preso, não foram considerados significantes para um intervalo de confiança de $95 \%$.

O uso ou não dos programas de troca de seringas e uso ou não de projetos contando com redutores de danos, também foram analisados como possíveis variáveis de proteção, não sendo encontrado nenhum resultado que indicasse que sua utilização fosse estatisticamente associado com uma menor odds ratio para infecção pelo HIV (quadro II).

Os aspectos relacionados ao comportamento de risco sexual, já foram analisados anteriormente neste trabalho. 
Tabela 4 - Análise Bivariada: Fatores de Risco X Infecção pelo HIV entre UDIs na Região Metropolitana de Santos

\begin{tabular}{lcccr}
\hline \multicolumn{1}{c}{ Variável } & \% HIV & OR & intervalo de conf 95\% & valor de p* \\
\hline Feminino & $72 \%$ & 2,30 & {$[1,40-3,60]$} & 0,0002 \\
Masculino & $53 \%$ & 1,00 & Referência & \\
Preso & $61 \%$ & 1,70 & {$[0,95-3,00]$} & 0,0562 \\
Nunca Preso & $48 \%$ & 1,00 & Referência & \\
Morador de Santos & $63 \%$ & 1,80 & {$[1,20-2,67]$} & 0,0046 \\
Morador RMS & $50 \%$ & 1,00 & Referência & \\
Compartilhamento & $71 \%$ & 3,00 & {$[2,00-4,40]$} & $<0,0001$ \\
Não Compartilhamento & $45 \%$ & 1,00 & Referência & \\
Uso de Crack Fumado & $53 \%$ & 0,70 & {$[0,47-1,05]$} & 0,0689 \\
Não Uso de Crack & $62 \%$ & 1,00 & Referência & \\
Injeção Diária & $69 \%$ & 1,80 & {$[1,20-2,90]$} & 0,0065 \\
Injeção Não Diária & $55 \%$ & 1,00 & Referência & \\
Injeção 0-2/dia & $52 \%$ & 1,00 & Referência & 0,0004 \\
Injeção 3-5/dia & $52 \%$ & 1,03 & {$[0,64-1,70]$} & \\
Injeção > 5/dia & $72 \%$ & 2,40 & {$[1,50-4,00]$} & \\
\hline
\end{tabular}

* Mantel Haensel $\chi^{2}$

Quadro 2 -Esforços de Prevenção para HIV por Estudo para UDIs da RMS, 1991-1999

\begin{tabular}{|l|l|l|l|}
\hline Intervenção & Estudo I & Estudo II & Estudo III \\
\hline PRD & Não existia & Existia $(\mathrm{n}=7)$ & Existia $(\mathrm{n}=14)$ \\
\hline PTS & Não existia & Não existia & Existia $(\mathrm{n}=13)$ \\
\hline
\end{tabular}

$\mathrm{PRD}=$ Programa de Redução de Danos sem troca de seringas

PTS = Programa de Troca de Seringas

$\mathrm{N}=$ pessoas que frequientaram o programa por Estudo

\section{IV.6.2 - Análise Multivariada (Regressão Logística)}

$\mathrm{Na}$ regressão logística considerou-se a infecção pelo HIV como variável dependente e o conjunto de variáveis já mencionadas na análise bivariada como variáveis independentes. As variávéis foram sendo paulatinamente retiradas à medida em que não apresentavam significância estatística (stepwise retrógrada).

Os resultados desta análise encontram-se na Tabela 5 abaixo.

Os fatores que remanesceram como sendo importantes para a transmissão do HIV foram: compartilhar seringas; fazer uso de drogas injetáveis diariamente e ser do sexo feminino. 


\begin{tabular}{lcc}
\hline \begin{tabular}{l} 
Tabela 5 - $\begin{array}{l}\text { Regressão Logística para risco de infecção pelo HIV, avaliando variáveis } \\
\text { independentes de comportamento, entre UDIs na Região Metropolitana de } \\
\text { Santos, 1991-1999 }\end{array}$ \\
\hline Variáveis
\end{tabular} Odds Ratio_Ajustado & $\begin{array}{c}\text { IC 95\% } \\
\text { Limite infer }- \text { limite super }\end{array}$ \\
\hline Compartilhamento & 2.67 & {$[1.79-3.26]$} \\
Uso Injetável Diário & 2.08 & {$[1.33-3.26]$} \\
Mulheres & 2.06 & {$[1.30-3.25]$} \\
\hline
\end{tabular}

\section{IV.6.3 - Outros Achados Relevantes para a Saúde da População Alvo}

Conhecimento sobre hepatites e informações sobre overdoses, foram novidades implementadas no Estudo III. Como já mencionamos, estes resultados não são comparáveis, visto que executados apenas no estudo III, entretanto pelo ineditismo e relevância das informações e sua relação direta com as consequiências para a saúde do uso indevido de drogas, concluímos ser informação complementar relevante para figurar neste trabalho.

Das 400 pessoas entrevistadas (108 UDIs, 100 ex-UDIs e 192 Uds), em apenas 20,8\% (85) dos questionários há alguma informação adequada, sobre pelo menos uma das formas de hepatites existentes. De todos os entrevistados, apenas $10 \%$ receberam alguma dose de vacina de hepatite $B$, e nenhum deles tomou as três doses necessárias para a imunização. De todos, 94,5\% gostariam de ser vacinados se houvesse a vacina disponível.

Da mesma forma são importantes os resultados encontrados sobre o risco de overdose que a população estudada corre. Dos entrevistados, $20 \%$ haviam tido pelo menos um episódio de overdose por uso de cocaína. Destes, 62\% estavam acompanhados quando o episódio ocorreu e $73 \%$ foram socorridos. A assistência durante os episódios de overdose foi prestada em $58 \%$ das vezes por um amigo também UD, em $13 \%$ das vezes por um parente não UD; em 12\% das vezes por um parceiro sexual e em $17 \%$ por outras pessoas.

Sessenta porcento da amostra testemunhou uma overdose de outra pessoa, sendo que $49 \%$ destas, ocorreram nos últimos 12 meses precedentes à entrevista. Os entrevistados tentaram socorrer em $90 \%$ das vezes, mas o fizeram com medidas adequadas em apenas $40 \%$ das mesmas. $50 \%$ dos entrevistados conhece alguem que morreu de overdose. $24 \%$ não procuraria serviço de saúde por temer ser mal atendido e $49 \%$ acredita que seria denunciado à polícia, pelo próprio serviço de saúde. 
$\mathrm{Na}$ análise multivariada (regressão logística) dois fatores foram associados ao fato dos entrevistados terem overdose em vida: ser mulher (odds ratio $=2,0$ ) e ter estado preso em vida (odds ratio $=2,3$ ) . 


\section{V - Discussão}

Os estudos aqui apresentados, mostram uma transição no padrão de consumo de drogas, que aconteceu mormente de meados para o final da década de 1990. O auge da epidemia de HIV/AIDS no Brasil entre usuários de drogas injetáveis, se dá exatamente nesta década. Os Estudos transversais, funcionam como uma espécie de bússola que mede a epidemia em seu momento de corte, antes que as taxas de infecção pelo HIV se reflitam em casos de doentes de AIDS.

Não obstante a dificuldade de se estabelecer um padrão, o perfil dos usuários de drogas injetáveis na região estudada se manteve mais ou menos o mesmo durante a década, sendo que as características demográficas apresentaram apenas mudanças brandas. Adultos jovens; em sua maioria homens, com menos de 8 anos de educação. O nível de emprego formal nunca atingiu os $20 \%$ durante todos estes anos, e uma parcela considerável admitiu subsistir de atividades ilegais. Mais da metade chegou a ser presa pelo menos uma vez após iniciar seu envolvimento com as drogas.

Estes achados, confirmam aquilo que a maioria dos autores no Brasil vêem demonstrando quanto ao perfil do usuário de drogas injetáveis. Caiaffa e colaboradores que empreenderam um amplo estudo nacional chamado Ajude Brasil, bem como Carvalho e colaboradores que se detiveram na cidade de São Paulo e mostraram seus dados na Conferência Mundial de AIDS em Durban, são alguns dos autores que corroboram o perfil encontrado no corrente estudo, que encontra no trabalho de pesquisadores brasileiros sua consistência externa $(67,68)$.

Na Tabela 1 acima vimos as modificações ocorridas em cada um dos estudos nas características demográficas das amostras analisadas. Há uma modificação temporal em algumas das características que merecem menção particular. Por exemplo sexo, onde no primeiro estudo houve um recrutamento maior de mulheres. Esta informação reflete o fato de no início da epidemia na região o uso de drogas injetáveis estar bastante associado às profissionais do sexo. $\mathrm{O}$ fato de atividade ilegal ser apontada como fonte de sustento de $45 \%$ dos entrevistados também no primeiro momento, tem uma íntima relação com a maior proporção de profissionais do sexo entrevistados então. Duas outras informações demográficas chamaram a atenção como possíveis fatores de confusão e merecem ser discutidas em sua particularidade. A variação na idade da amostra, que foi estatisticamente significativa na análise 
univariada, foi uma variação proporcional ao tempo decorrido entre o primeiro e o terceiro corte seccional. Note-se que nos casos das duas extremidades (mais novos e mais velhos) houve inversão de situação em relação ao Estudo I, ou seja, aumentaram com o tempo os entrevistados mais velhos e diminuíram na mesma proporção os entrevistados mais novos. Outro fator que pode ter influenciado esta inversão é o fato de que com o passar dos anos, houve uma menor inserção de usuários mais novos na prática de uso injetável de drogas. A variável idade no entanto, perde importância e não se expressa na análise bivariada.

O fato do entrevistado recrutado ser ou não morador da cidade de Santos foi outra variável que poderia gerar confusão. Significante nas análises univariadas e bivariadas, esta característica não subsistiu à análise multivariada. Vale ressaltar que mesmo no estudo III, onde a maioria das pessoas entrevistadas não tinha origem em Santos, fez de Santos em 50\% dos casos, seu local de iniciação do uso de drogas injetáveis. O achado sugere que a conurbação da Região Metropolitana de Santos, leva os usuários de drogas a utilizarem drogas na "região" em vez de na "cidade", e a reproduzir na região formas de uso de drogas similares.

As características relacionadas à atividade sexual protegida da amostra em questão apontam para uma tendência que não variou muito durante a década estudada. $O$ fato de muitos dos programas de prevenção concentrarem suas atividades para esta população especifica na questão da transmissão parenteral, pode ser responsável por parte da explicação do fenômeno. De outro lado, o fato dos programas de prevenção não terem cobertura suficiente, pode ser outro fator que influencia este comportamento.

Portanto exceto um agravamento no risco de transmissão de HIV e de outras patologias de transmissão sexual para parceiros fixos, que mesmo assim não se mostrou significativo, não houve mudança no comportamento sexual dos usuários de drogas injetáveis em toda uma década.

Este achado, tem paralelo na experiência internacional de controle da epidemia de AIDS, que aponta para uma tendência maior de mudança de comportamento quanto ao uso de drogas, do que quanto a transmissão sexual. Rhodes e colaboradores estudaram com maior profundidade a sexualidade dos 
usuários de drogas injetáveis. Seus achados são completamente coerentes aos dos estudos aqui apresentados $(91,92)$.

A questão de gênero, aparece aqui com uma importância relativamente grande, conforme também mencionam outros autores em questões da transmissão do HIV. Pesquisadores de diversos países como Goldestein, Scheper-Hughese e Giffin com seus grupos de colaboradores, bem como pesquisadores brasileiros coordenados por Ventura-Felipe, em trabalhos de bastante profundidade, analisam as dificuldades do enfrentamento da epidemia de HIV/AIDS no Brasil onde a relação de gênero é bastante desfavorável às mulheres (93-96). Em uma sociedade machista, onde prazeres e riscos são controlados pelos parceiros sexuais do sexo masculino, as mulheres se colocam de maneira inferiorizada no relacionamento a dois. Isto portanto acaba se traduzindo no risco maior também das mulheres usuárias de drogas injetáveis para a transmissão do HIV como sugere o presente estudo, nos resultados apresentados pela análise multivariada. Ainda como subproduto deste Estudo, o autor encontrou a mesma associação de maior risco para as mulheres no relato de overdoses. Ou seja, ser mulher aparece como variável independente significante quando relacionada à overdose como variável dependente(97). É importante ponderar que os programas de redução de danos trabalham com uma abordagem genérica que não distingue ações específicas por gênero, mesmo considerando que vários dos Redutores de Danos são do sexo feminino.

As limitações das políticas públicas de drogas e saúde, se refletem nos achados de outras alterações relativas ao padrão de consumo de drogas. Parece que muito mais do que uma decisão tomada como fruto da ação da saúde pública, o crescimento do uso de cocaína em forma de pedra de crack na população estudada, deu-se entre outras causas por uma decisão comercial do tráfico de drogas. É preciso ficar claro que seria indefensável do ponto de vista das autoridades de saúde, o incentivo ao uso de crack, como forma de desestimular o uso de cocaína injetável. Esta afirmação está centrada nos prejuízos à saúde geral (à parte da AIDS e outras doenças de transmissão paraenteral), que o crack causa aos seus usuários. Dunn e Laranjeiras em recente trabalho publicado na revista Addiction estabelecem outras motivações para a mudança de padrões de consumo de drogas, sobretudo nas vias de administração(46). A formação psicoterapêutica dos autores, leva toda a condução do 
estudo para as causas de motivação individual das mudanças ocorridas no consumo. Embora de grande valia como ponto de apoio para uma análise mais ampla, é preciso ir além do indivíduo para buscar as causas de tal modificação e suas consequências para a saúde, como bem descreveram Mann e Ayres e seus colaboradores quando desvendam a teoria da vulnerabilidade, aplicável no caso em questão( 6,7$)$.

$O$ fato é que houve no presente estudo, uma expressiva modificação no padrão de consumo de drogas injetáveis. Nas análises bivariadas, dois fatores de risco aparecem com uma mudança que parece se associar diretamente a diminuição da transmissão do HIV. O número de dias que os entrevistados injetam por mês (frequêencia diária de uso com associação significativa) e o número de injeções diárias (mais de cinco vezes por dia, com uma forte associação),diminuiram. A análise multivariada (regressão logística) reitera que a injeção diária foi um dos fatores marcantes na possível associação com a transmissão do HIV.

Além disto, o compartilhamento de agulhas e seringas que inicialmente tem uma ascensão de $55 \%$ (Estudo I) para $71 \%$ (Estudo II); tem uma queda abrupta para $24 \%$ no Estudo III, e também aparece como fator decisivo na análise multivariada.

Estas três modificações na forma de uso injetável, têm como consequiência uma queda acentuada na soroprevalência do HIV que dos $63 \%$ e $65 \%$ dos dois primeiros Estudos, cai para $42 \%$ no Estudo final. A mesma queda pôde ser observada nas taxas de hepatites.

Estes dados, melhores dispostos no Gráfico I e no Gráfico II, somam-se a um crescimento muito expressivo do uso de crack, entre esta população de poli usuários, aqui já analisado. Houve portanto, uma queda de comportamentos de risco quanto ao uso de drogas injetáveis bastante expressiva. O aumento do consumo de crack pode ter entrado como fator de substituição preenchendo o vazio deixado pela diminuição do consumo da droga injetada.

Paralelamente a isto, uma série de informações indiretas levam a inferir que a estratégia de ampliação do mercado consumidor de cocaína no Brasil pelos traficantes de drogas, fez com que a cocaína em pedra para consumo, principalmente fumada (crack), tomasse grande parte do mercado. Somados a este fator: o preço mais baixo, a facilidade de porte e uso, a velocidade com que o efeito da droga se manifesta, dentre outros, auxiliaram como descreveram Mesquita e colaboradores e 
Dunn e Laranjeiras, na transição para o aumento de cocaína utilizada em forma de crack $(45,46)$

Assim paulatinamente, a cocaína injetável passou de uma das principais drogas de uso, a uma droga de uso complementar e menos frequiente, diminuindo como já vimos, em muito os dias de uso, a quantidade usada em um mesmo dia e o compartilhamento de seringas e de agulhas.

Quando tentamos medir a eficácia direta dos programas de intervenção (outreach work nos Estudos II e III e Programa de Trocas de Seringas no Estudo III), vemos que sua ação foi completamente insuficiente. De toda a amostra envolvida nos 3 Estudos, cerca de 12\% tiveram acesso ao Programa de Outreach Work. Este número é insignificante, mesmo considerando que este programa estava disponível apenas no segundo e terceiro Estudos. Já nos de troca de seringas, apenas $10 \%$ das pessoas tinham este programa como sua principal fonte de fornecimento de seringas limpas, mesmo considerando que o programa estava implantado apenas nos últimos 2 anos anteriores ao ultimo estudo. Freqüentar qualquer um destes dois programas, não fez a menor diferença nas taxas de infecção pelo HIV. As análises bivariadas apenas sugerem a reiteração desta observação.

Embora não seja o único fator de controle das epidemias mundo afora, os programas de redução de danos no geral, e os de troca de seringas em particular, foram descritos por autores clássicos como Wodak, Lurie e Stinsom (dentre outros autores) como sendo estratégicos no controle das epidemias de HIV/AIDS entre usuários de drogas injetáveis e deles para a população geral $(48,53,98)$. O fato de no presente estudo a inserção do público estudado neste referidos programas ser muito baixa, é um fator que teoricamente dificulta em muito o sucesso no controle da disseminação do HIV.

Uma luta política intensa entre autoridades de saúde e autoridades jurídicopoliciais, retardou a implantação e diminuiu em muito a magnitude dos programas de redução de danos propostos para enfrentar o problema. Ainda somou-se a isto a falta de recursos financeiros suficientes para estender estes programas as suas reais demandas, em um Sistema Único de Saúde que não tem recursos para outras questões também importantes. Mesmo considerando que estes programas tiveram um investimento real adicional com recursos da CN DST/AIDS no âmbito do Projeto do 
Banco Mundial e em conjunto com recursos da UNDCP, diferentes de outras áreas do SUS que lutam por recursos. Estes recursos no entanto, só chegaram aos trabalhos na ponta de fato a partir de 1996 (apesar de existirem desde 1993). O número de projetos foi insuficiente para um país da dimensão do Brasil. Cabe ainda ressaltar que mesmo estes programas existentes careciam de inserção real, neste precário Sistema Único de Saúde. Ademais, os serviços de saúde existentes, nem sempre eram convidativos para a clientela alvo. Finalmente não é demais lembrar que em nenhuma circunstância as iniciativas de saúde pública isoladamente devam ser superestimadas. Freqüentemente elas atingiram objetivos aquém daqueles que desejamos(99). Em suma, a intervenção originária destas contradições, foi tardia e pequena, pelo menos no caso da RMS.

Pela primeira vez em nosso meio, um Estudo tem parâmetros basais, intermediários e posteriores, para medir o quanto uma intervenção de saúde para uma população de usuários de drogas injetáveis tem repercussão. Embora este não seja o único objetivo do presente estudo, o ineditismo deste aspecto do estudo merece destaque.

No entanto não seria correto analisar o papel dos programas de redução de danos apenas por sua ação direta. Um dado relevante é o que aponta o fato de que após saber sobre a epidemia de AIDS, uma parcela dos entrevistados mudaram seu comportamento que expunha ao risco de infecção pelo HIV, conforme mencionado no capítulo de resultados deste trabalho, sob o subtítulo Mudanças de Comportamento Influenciadas pelo Conhecimento de HIV/AIDS.

Estes resultados, demonstram que uma parcela crescente de usuários de drogas injetáveis foram se tornando mais conscientes dos riscos de infecção pelo HIV nestes 10 anos. Este dado, que poderemos considerar um certo elemento de sucesso para as ações da saúde, é provavelmente fruto do intenso debate sobre a necessidade ou não de implantar programas de redução de danos que se travou na região na década em estudo. Também é bastante conhecida a forma de comunicação peculiar de usuários de drogas, pessoa a pessoa. Os projetos em curso, ainda que não tenham tido ampla abrangência, certamente contribuíram para estas mudanças verificadas no comportamento da população estudada. $O$ índice de $72 \%$ de mudança de comportamento observado no Estudo III, embora crescente e importante, é ainda 
bastante inferior aos encontrados em países de primeiro mundo e mesmo em países como a Tailândia, no início da década de 1990. Autores diversos como Des Jarlais e colaboradores, bem como o Grupo Colaborativo do Estudo Multicêntrico de HIV entre UDIs da Organização Mundial de Saúde, dedicaram parte de seus estudos para a análise destas mesmas mudanças (100-103).

Outro fator relevante que merecerá análise posterior é o impacto que a introdução da terapia antiretroviral para os doentes de AIDS, iniciada em Santos em 1996 e a seguir estendida para outras cidades da região teve na disseminação do HIV, visto que seu uso tem impacto importante na carga viral e portanto provavelmente na transmissão do HIV. O Brasil tem tido enorme destaque nos últimos dias na imprensa leiga por sua iniciativa de sucesso nesta área, a despeito da opinião de países e organizações contrários à atitude brasileira.

É difícil definir categoricamente qual o fator determinante, mas a soma de fatores que inclui: a decisão comercial do tráfico de drogas; a opção de mudança de via de administração de drogas do próprio usuário; os efeitos indiretos dos programas de troca de seringas, de redução de danos e de outras políticas públicas de saúde dirigidas a este segmento; o aumento da consciência dos usuários de drogas, a introdução da terapia antiretroviral nesta comunidade, dentre outros fatores; de fato levou a uma modificação dos padrões de uso de drogas e a uma diminuição expressiva de risco de infecção pelo HIV por via injetável, que são o principal achado deste trabalho.

Importante também é analisar o que chamamos de outros achados relevantes para a saúde da população alvo: hepatites e overdoses. As taxas de soroprevalência de hepatites não foram analisadas neste trabalho com a profundidade que demos as análises das taxas de HIV. Entretanto, é pertinente o comentário de que a queda nas taxas de hepatite $\mathrm{C}$ foi maior que a queda nas taxas de hepatite $\mathrm{B}$ durante estes 10 anos de estudo, em função da similaridade nas formas de transmissão da hepatite C e do HIV. O crescimento do uso de crack com a diminuição da utilização da cocaína injetável; a diminuição na quantidade de droga utilizada por via injetável e de dias injetados; a morte de várias pessoas ao longo dos anos foram dentre já mencionados para as taxas de HIV, fatores que empurraram para baixo as taxas de soroprevalência de hepatites $\mathrm{B}$ e $\mathrm{C}$. A pequena diferença na queda de hepatite $\mathrm{C}$ para $\mathrm{B}$ de $7 \%$, pode 
ser explicada pela não alteração no comportamento sexual da população estudada. Como se sabe, a hepatite B tem transmissão sexual importante, quase inexistente na hepatite C. Utilizar as hepatites como marcador biológico não foi no entanto a intenção do presente estudo, e para uma análise mais conclusiva, novos estudos deverão ser realizados com este fim específico.

Chama muito a atenção no entanto, o baixíssimo conhecimento que os entrevistados no Estudo III (o único a analisar este quesito) têm sobre as hepatites de maneira geral. O baixo índice de vacinados também é destaque, bem como a aspiração por uma vacina; que foi bastante acentuada.

Este quadro demonstra uma necessidade de se ampliar o espectro dos trabalhos de prevenção e assistência dirigidos aos usuários de drogas. Incorporar ao trabalho que vem sendo realizado com HIV/AIDS as informações sobre hepatites, parece uma tarefa fácil e de grande relevância. Da mesma forma, serviços que já atendem usuários de drogas, podem fornecer, sobretudo para os que fazem uso de drogas injetáveis, vacina de hepatite $\mathrm{B}$, nas doses necessárias. Esta última medida, evitaria que um fígado atingido pela hepatite $C$, e eventualmente por uma medicação antiretroviral hepatotóxica, tivesse sua situação geral agravada. Como argumento adicional, hepatite $\mathrm{B}$ é uma doença considerada de transmissão sexual (DST) e portanto deve ser tema relevante para os Programas de Doenças Sexualmente Transmissíveis e AIDS.

O mesmo poderia se dizer do risco de overdose a que a população estudada está exposta. Os índices de pessoas que experimentaram ou testemunharam overdoses foi também surpreendente. Isto se soma ao número também expressivo dos que referiram conhecer episódios fatais. Em muitas das vezes, o usuário está acompanhado de seus amigos usuários, familiares ou parceiros sexuais (nesta ordem) que são as pessoas que mais freqüentemente os socorrem. Muitos desconfiam do sigilo dos serviços de saúde e atribuem a estes uma grande ligação com as forças de repressão.

Informações complementares ao estudo, dão conta de que há um enorme subregistro de casos de overdose na RMS, o que provavelmente reflete a situação similar em outras partes do Brasil (45). Há três hipóteses que nosso grupo de pesquisadores analisa como prováveis causas do fenômeno: o SUS não remunera 
overdose; os médicos de salas de emergência não sabem diagnosticar adequadamente overdose de cocaína; os pacientes temendo a denúncia à polícia e o mal atendimento preferem soluções caseiras para estes casos(97).

Da mesma forma que os serviços de saúde precisam "olhar" mais para os casos de hepatites, os casos de overdose merecem a mesma atenção (aponta o presente estudo), do que aquela que se dedica à prevenção e assistência do HIV. Utilizar drogas, sobretudo as injetáveis, traz uma série de consequiências à saúde e temos de pensar as ações que contemplem este conjunto. 


\section{VI - Conclusões e Considerações Finais}

O objetivo deste estudo de analisar as tendências da epidemia de HIV/AIDS bem como seus determinantes entre os usuários de drogas injetáveis na Região Metropolitana de Santos durante a década de 1990, parece ter avançado neste estudo.

O estudo possibilitou a oportunidade inédita de analisar as consequêencias para a saúde do uso de drogas injetáveis em três períodos distintos da história. Virgem de intervenção (no Estudo I); com a intervenção dos "redutores de danos" (Estudo II) e com a intervenção destes e dos programas de trocas de seringas (oficialmente dois em curso em Santos e um em curso em São Vicente) no Estudo III.

Da mesma forma tivemos a oportunidade inédita de estudar e portanto compreender melhor um fenômeno relativamente pouco estudado até o início dos anos 90, que se consolidou na sociedade brasileira nesta década, que é o uso de drogas injetáveis. A associação do uso de drogas injetáveis ao uso de cocaína, fez a Região Metropolitana de Santos ser conhecida como uma das de maior taxa de soroprevalencia de HIV entre usuários de drogas injetáveis no mundo $(1,103)$. Esta mesma associação foi determinante no rápido crescimento da epidemia de HIV/AIDS no Brasil como um todo (75).

O crescimento do consumo de crack na segunda metade da década de 90 , possivelmente decidida por uma estratégia comercial do tráfico de drogas, não significou o fim do uso de drogas injetáveis. Além disto, com motivações similares, outras drogas injetáveis ou até mesmo a cocaína injetável, podem retomar seu espaço no dinâmico mercado de drogas.

Chama a atenção a modificação de comportamento para melhor, que os usuários de drogas injetáveis tiveram nestes dez anos. Contrariamente ao senso comum, é possível modificar comportamento de usuários de drogas injetáveis, como foi possível depreender do presente estudo e como vem sendo reiterado por outros pesquisadores. Uma mescla de causas, como já vimos anteriormente, que vão do temor da epidemia de AIDS à praticidade do uso do crack, se somou para que estas modificações fossem possíveis no estudo aqui analisado.

Ficou claro também que a modificação do comportamento sexual dos usuários de drogas injetáveis, não se deu na mesma dimensão que a da modificação 
do comportamento em relação ao uso de drogas. Basicamente não houve sexo mais seguro que anteriormente (no caso de parceiros principais a situação chegou mesmo a piorar).

Na relação de gênero, a mulher usuária de drogas injetáveis é vitima de iniquiidades que devem ser tratadas com a particularidade que merece. $O$ estudo sugere fortemente que ser mulher é uma associação de risco para a transmissão do HIV entre os usuários de drogas injetáveis. Duplamente discriminada como mulher e usuária de drogas injetáveis, elas demonstraram ser um elo ainda mais fraco nesta corrente de discriminação. Outros estudos aqui mencionados já apontavam para inferioridade das mulheres na negociação do uso do preservativo; na maior exposição a overdoses de cocaína; além da clara discriminação em outras situações em que ser mulher se constitui em risco de agravo à saúde.

Enfim ao analisarmos a tendência da epidemia na história destes 10 anos, concluímos que o risco de infecção se manteve basicamente igual por via sexual e foi bastante modificado por via paraenteral, causando um profundo impacto nas epidemias de HIV/AIDS e de hepatites. Esta conta no entanto não pode ser feita com uma simples subtração. Não se trata de uma diminuição de taxas de infecção pelo HIV de 65\% (em 1996) para 42\% (em 1999). Muitos dos entrevistados nos Estudos anteriores possivelmente morreram, e surgiram tantos outros novos infectados no caminho. A baixa cobertura dos programas de redução de danos reforça a idéia de que a transmissão não acabou, mas que embora modificada por outros fatores apresentados ao longo desta tese, continua um fenômeno importante. Com taxas de soroprevalência de HIV entre UDIs de $2 \%$ na Austrália, ou 3\% no Reino Unido, não podemos pensar que nossos $42 \%$ são exatamente uma vitória. Lamentavelmente o Brasil carece de estudos de incidência de HIV entre UDIs, que poderiam auxiliar melhor na compreensão desta informação.

Mesmo assim, os achados da Região Metropolitana de Santos, que detém $4 \%$ dos casos de AIDS de todo o Brasil e que tem expressão importante na geografia da AIDS do Estado de São Paulo, embora não possam ser generalizados do ponto de vista estrito da Epidemiologia, devem servir de luz para as autoridades de saúde da região, do Estado de São Paulo e do país. 
Também chama a atenção, e este autor vem reiteradamente insistindo, que o fenômeno de drogas é muito complexo. Envolvendo aspectos políticos, comerciais, de relações exteriores, jurídicos, de crime organizado, dentre tantos outros, suas consequiencias para a saúde, são apenas a ponta de um iceberg da complexidade de tal fenômeno. Portanto não existem conclusões simples e menos ainda definitivas sobre um estudo que envolve fenômeno de tal dimensão.

Vimos no entanto, o quanto a luta política por uma política de drogas mais tolerante é fundamental para o desenvolvimento de uma proposta de saúde mais ampla. O debate que tomou proporções policiais e de ações jurídicas contra as autoridades de saúde e as ONGs, retardou e minimizou o impacto das ações de saúde impedindo que centenas de vidas fossem salvas. Embora o debate tenha propiciado em certa medida a divulgação de informações, este processo impediu que os programas implantados a duras penas, tivessem a abrangência correspondente à dimensão das epidemias virais e de outras conseqüências indesejáveis para a saúde do usuário de drogas injetáveis. Claro que não poderemos subestimar o quadro de saúde precário no qual o Brasil vive, e dentro do qual as respostas à estes problemas deveriam ter sido dadas. No entanto nos últimos anos têm havido formas criativas de trabalhar no Sistema Único de Saúde, com respostas bastante adequadas nas várias áreas de atuação. Neste caso em especial, há ainda que se considerar que houve recurso específico (CN DST/AIDS- Banco Mundial - UNDCP) pelo menos a partir de 1996. Mesmo com todas as limitações, estas intervenções poderiam ter obtido maior sucesso.

À luz destas conclusões é preciso implementar em muito os programas de redução de danos investindo os recursos necessários para tanto. Ademais, é preciso que os programas saiam da cultura da clandestinidade no qual foram criados e se engajem plenamente no Sistema Único de Saúde, não perdendo sua característica de busca ativa da população alvo. É possível mantê-los nos serviços e nas ruas, buscando a ampliação da cobertura de suas ações. Estes programas devem ainda dedicar especial atenção as questões do sexo seguro, vendo sua população alvo como um ser total e sexuado. Não se pode pensar uma intervenção que não dê especial atenção às mulheres UDIs em um quadro com a diferença de gênero que aqui encontramos. 
Mais do que excelentes programas de HIV e AIDS, é preciso que o espectro dos programas de saúde dirigidos aos usuários de drogas levem em consideração outros de seus principais agravos de saúde. Como a maioria dos programas de ação que têm UDIs como sujeito são também programas de DSTs, é inaceitável que eles não tratem com a mesma atenção a transmissão da hepatite B. Doença prevenível por vacinação, torna-se omissão de socorro que os programas de DST/AIDS não dêem atenção a hepatite $B$. No caso da hepatite $C$, ela é hoje a doença que mais rapidamente se dissemina no mundo pelo compartilhamento de agulhas e seringas. Epidemia de um futuro próximo, não pode esperar chegar às proporções alarmantes que chegou a epidemia de HIV/AIDS entre UDIs, para que as autoridades de saúde tomem providências para prevenir e tratar suas vítimas. Especialistas apontam que hoje já há uma epidemia de hepatite $C$ no país, ainda não madura, mas que em um futuro breve poderá trazer enormes conseqüências ao SUS. Ainda devemos recomendar atenção para as Overdoses de cocaína , que devem sem nenhuma dúvida estar entre as preocupações das autoridades sanitárias. Com o mesmo espírito, é preciso rever no SUS o pagamento de overdose e criar um Sistema de Vigilância específico, que inclua treinamento de pessoal de emergência. Estas preciosas vidas não podem ser perdidas por omissão dos serviços de saúde. A maior parte destas mortes são preveníveis.

Neste contexto amplo de uma mudança dos programas de saúde dirigidos aos usuários de drogas, a luta pela organização dos próprios usuários de drogas e por uma política pública de drogas que respeite os direitos individuais de cidadania, são peças imprescindíveis. Em um ambiente repressivo as ações ficam limitadas e não têm o mesmo efeito potencial. Novamente não podemos cair na tentação de pensar que todas as soluções possam advir da Saúde Pública isoladamente. Mesmo assim, a Saúde pode jogar um importante papel, sobretudo se for atraente para a clientela. Um dos passos chaves é conquistar a credibilidade da população alvo, por exemplo deixando sempre claro que a Saúde nada tem a ver com a Segurança Pública, pelo menos enquanto este setor só pensar em repressão.

O Estado Brasileiro, a exemplo do Estado Suíço e de outros, deverá tomar as iniciativas de políticas públicas de drogas em suas mãos, antes que os traficantes o façam. Organizações Não Governamentais; Redes de Intelectuais ou trabalhadores; 
pesquisadores; Universidades como Instituições, dentre outros setores, também estão chamados a dar sua contribuição. Portanto, cabe também à sociedade civil brasileira destacado papel na luta para salvar milhares de vidas das pessoas que usam drogas e estão expostas a esta situação inaceitável que aqui debatemos. 


\section{VII - Referências Bibliográficas}

1. Stimson, G; Choopanya K. "Global Perspectives on Drug Injecting". In Stinson, Ball and Des Jarlais, editor. Drug Injecting and HIV Infection: Global Dimensions and Local Response. London - UK: Taylor and Francis, 1998

2. Strathdee S; Ameijden EJC; Mesquita, F; Wodak, A; Rana, S. \& Vlahov, D. Can HIV epidemics among injecting drug users be prevented? AIDS 1998;12:S71-S79

3. Nadelmann E. Commonsense Drug Policy. Foreign Affairs 1998;77:111126.

4. Escohotado A. A Proibição: Princípios e Consequiências. In: Ribeiro MS, S, ed. Drogas, Hegemonia do Cinismo. São Paulo: Memorial da América Latina, 1997:29-46.

5. Bastos FI. "Um Conto de Quantos Países". In: Bastos FI, editor. Ruína e Reconstrução; AIDS e Drogas Injetáveis na Cena Contemporânea. Rio de Janeiro: Relume Dumara, 1995:77 - 98

6. Mann, J; Tarantola, D; Netter, T. AIDS in the World. Cambridge, USA: Harvard University Press; 1992.

7. Ayres, JR; França Jr, I; Calazans, G; Saletti, HC. "Vulnerabilidade e Prevenção em Tempos de AIDS”. In: Barbosa, R e Parker, R, editores. Sexualidade Pelo Avesso, Direitos, Identidades e Poder. Rio de Janeiro: Editora 34; 1999 p. 49-72.

8. Carlini, E; Galduroz, JC; Noto, AR; Nappo, S; Lima, E; Adiala, JC. Revisão - Perfil do uso de cocaína no Brasil. Jornal Brasileiro de Psiquiatria, 1995; 44(6):287-303.

9. Mesquita, F. "Perspectivas das Estratégias de Redução de Danos no Brasil". In Mesquita, F \& Bastos, FI, editores. Drogas e AIDS, Estratégias de Redução de Danos. São Paulo: HUCITEC, 1994

10. Secco A. O Poder dos Barões do Tráfico. Revista Veja, 8 de dezembro de 1999:40-47 
11. Machado LO. "Movimento de Dinheiro e Tráfico de Drogas na Amazônia". In Seibel, S \& Ribeiro, M, editores. Drogas, Hegemonia do Cinismo. São Paulo: Memorial da América Latina, 1997: 217 - 242.

12. Bastos, FI \& Mesquita, F. "Redução de Danos (RD) hoje: enfrentando os desafios da epidemia de HIV/AIDS e as Hepatites virais em usuários de drogas injetáveis (UDIs)”. In Seibel, $\mathrm{S} \&$ Tosacno Jr, A, editores. Dependência de Drogas. Rio de Janeiro: Editora Atheneu; no prelo.

13. Bueno R. "Estratégias de Redução de Danos em Santos". In: Mesquita F, \& Bastos, FI, editores. Troca de Seringas : Drogas e AIDS; Ciência, Debate e Saúde Pública. Brasília: Ministério da Saúde do Brasil, 1998:163-169

14. Mesquita F. "Dar Oportunidade de Vida ao Usuário de Drogas Injetáveis Polêmica Nacional". In: Mesquita, F \& Bastos, FI editores. Troca de Seringas: Drogas e AIDS; Ciência, Debate e Saúde Pública. Brasília: Ministério da Saúde do Brasil, 1998:101-112.

15. WHO Collaborative Study Group. Final Report of the Multi-City Study on Drug Injecting and Risk of HIV Infection. Geneve: Program on Substance Abuse - World Health Organization, 1994.

16. Carvalho, HB; Mesquita, F; Massad, E; Bueno, R; Turienzo, G; Ruiz, A and Burattini, M. HIV and Infections of Similar Transmission Patterns in a Drug Injectors Community of Santos, Brazil. Journal of Acquired Immune Deficiency Syndromes and Human Retrovirology 1996;12:84-92.

17. Carvalho, H; Bueno, $\mathrm{R} \&$ Projeto Brasil Collaborative Study Group. "Infecção pelo HIV e seus determinantes em sete cidades brasileiras" Projeto Brasil. In Mesquita,F \& Seibel, $S$ editores. Consumo de Drogas: Desafios e Perspectivas. São Paulo: HUCITEC, 2000:.

18. Bueno, R; Lurie, P; Mesquita, F; Turienzo, G; Haieck, R. Bleaching Among IDUs in Santos, Sao Paulo, Brazil. XI International AIDS Conference. Vancouver, 1996.

19. Mesquita, F; Bueno, R; Kral, A; Reingold, A; Araujo, PJ; Trigueiros, DP and SMR Collaborative Study Group. Trends of HIV epidemic related to the changes in drug using patterns among injetion drug users in Santos, Brazil, 
during the 1990's. In: XIII International AIDS Conference; 2000 Junho, Durban, África do Sul, 2000.

20. DATASUS. TABNET-AIDS, Estado de São Paulo: DATASUS - Ministério da Saúde do Brasil, on line no www.saude.gov.br em abril de 2000.

21. UNDCP. Drug Money in a Changing World: Economic Reform and Criminal Finance. Viena: United Nations International Drug Control Program, 1996.

22. Roio J. "Mundialização e Criminalidade" in In Seibel, S \& Ribeiro, M, editores. Drogas, Hegemonia do Cinismo. São Paulo: Memorial da América Latina, 1997: $109-124$.

23. (TED) TaED. “A Case Study: Colombia Coca Trade”. Washington, D.C.: American University, 1997:4.

24. Congress US. Alternative Coca Reduction Strategies in the Andean Region: US Government Printing Office, Washington, D.C., 1993:F-556.

25. Nadelmann, E. Cops Across Borders: The Internationalization of U.S. Criminal Law Enforcement. Pittsburg: Pennsylvania State University Press; 1993.

26. Stannard, MB. How we lost the War on Drugs. The Oakland Tribune. Oakland, 1999: Capa, pag 11, pag 12 e pag 13.

27. Golden T. US Antidrug Plan to AID Colombia faces Skepticism. New York Times. New York, 2000:Capa e pag 4.

28. Mesquita F. AIDS na Rota da Cocaína. São Paulo: Editora Anita Garibaldi, 1992.

29. Bastos FI. Apontamentos para uma geografia social da AIDS no Brasil, com ênfase no papel dos UDIs. In: Bastos FI, editor. Ruína e Reconstrução; AIDS e Drogas Injetáveis na Cena Contemporânea. Rio de Janeiro: Relume Dumara, 1995:49-76.

30. Escohotado A. Historia General de las Drogas, em três volumes. Madrid: Alianza Editorial, 1989.

31. SAMHSA -. Marihuana Tax Act. Rockville, MD: SAMHSA, 1997:23.

32. Wright $K \&$ Lewin P. Drug War Facts. Washington, D.C.: Common sense for Drug Policy, 1998 
33. Health, Dutch Ministry. Drug Policy in Netherlands - Continuity and Change. Amsterda: Dutch Ministry of Health Welfare and Sports, 1995.

34. Statistics BoJ. Profile of Jail Inmates, 1996. Washington, D.C.: Bureau of Justice Statistics, 1997.

35. Antidrogas, Secretaria Nacional. Relatório Preliminar do I Fórum Nacional Antidrogas. Brasília, DF: Secretaria Nacional Antidrogas, 1998.

36. Drucker E. Consequiências das Políticas Norte-americanas de Drogas Sobre as Ações de Saúde Pública. In: Mesquita, F; Bastos, FI, editores. Drogas e AIDS; Estratégias de Redução de Danos. São Paulo: HUCITEC, 1994:5562.

37. Marks J. Dosagem de Manutenção de Heroína e Cocaína. In: Seibel, S \& Ribeiro M, editores. Drogas, Hegemonia do Cinismo. São Paulo: Memorial da América Latina, 1997:269-281.

38. Drucker E. Drug Prohibition and Public Health: 25 Years of Evidence. The Drug Policy Letter, 1999:1-18.

39. Health, Swiss Federal Office of Public. The Swiss Drug Policy - A fourfold approach with special consideration of the medical prescription of narcotics. Bern: Swiss Federal Office of Public Health, 1999.

40. Editorial Board. The Andean Coca Wars: a crop that refuses to die. The Economist 2000 March, 354:23-25.

41. Ennett, ST; Tobler, NS; Ringwalt, CL; Flewelling, R. How Effective is Drug Abuse Resistance Education? A Meta-Analysis of Project DARE Outcome Evaluations. American Journal of Public Health 1994;84:1394-1401.

42. Wysong, E; Aniskiewicz, R; Wright, D. Truth and DARE: Tracking Drug Education to Graduation and as Symbolic Politics. Social Problems $1994 ; 41: 3-34$.

43. Aureano, G; Fortmann, M; Lopez, M. Calidoscopio, La Instrumentalizacion Politica del Problema de las Drogas en el Continente Americano. Analises $1999 ; 2: 87-95$.

44. Latin American Travelling Seminar. Cerimônia de Encerramento do Seminário de Recife, Pe, Brasil. General Cardoso, on line no www.lats.org ; setembro de 2000 . 
45. Mesquita, F; Bueno, R; Araujo, PJ; Trigueiros, DP; Turienzo, G; Haddad, I. Rapidly responding to injecting drug use and HIV in Brazil: a field-report from São Vicente, São Paulo State. International Journal on Drug Policy, , 2000; 11(1,2):133-144.

46. Dunn, J \& Laranjeiras, R. Transitions in the route of cocaine administration characteristics, direction and associated variables. Addiction 1999;94(6):813824.

47. Verster A. Os Programas de Troca de Seringas em Amsterdã. In: FI MFB, ed. Troca de Seringas: Drogas e AIDS; Ciência, Debate e Saúde Pública. Brasília - DF: Ministério da Saúde do Brasil, 1998:115-124.

48. Stinsom G. A AIDS e o Uso de Drogas Injetáveis no Reino Unido, 19871993: As Políticas Públicas e a Prevenção da Epidemia. In: Mesquita F \& Bastos F, ed. Troca de Seringas: Drogas e AIDS; Ciência, Debate e Saúde Pública. Brasília - DF: Ministério da Saúde do Brasil, 1998:9-54.

49. Trigueiros, DP; Mesquita, F; Bueno, R; Araujo, PJ; Haddad, I; Turienzo, G; Sanches, M. Hepatitis among drug users in Brazil: lack of information and it's consequences. In: $11^{\text {th }}$ International Conference on the Reduction of Drug Related Harm; Jersey GB, 2000.

50. Mesquita, F; Bueno, R; Trigueiros, DP; Araujo, PJ; Haddad, I; Turienzo, G; Sanches, M. Overdoses among cocaine users in Brazil. In: $11^{\text {th }}$ International Conference on the Reduction of Drug Related Harm; Jersey GB, 2000.

51. Gumucio, JH. Cocaine, the Legend. Segunda Edição. La Paz, Bolívia: ICORI; 1995.

52. Labigalini, E; Rodrigues, LR; Xavier, DS. Therapeutic use of Canabis by Crack Addicts in Brazil. Journal of Psychoactive Drugs 1999;31:451-455.

53. Wodak A. Estratégias para a Prevenção da Infecção pelo HIV entre Usuários de Drogas e Destes para seus Parceiros. In: Mesquita, F; Bastos, FI, ed. Drogas e AIDS; Estratégias de Redução de Danos. São Paulo: HUCITEC, 1994:115-132.

54. Siqueira, D; Winkler, G; Barcellos, N; Mayer, R; Conte, M; Fernandez, O. O Projeto de Redução de Danos no Rio Grande do Sul. In: Mesquita, F; Bastos, 
FI, ed. Troca de Seringas: Drogas e AIDS; Ciência, Debate e Saúde Pública. Brasília - DF: Ministério da Saúde do Brasil, 1998:171-184.

55. Mott L. Epidemic of Hate. San Francisco: International Gay and Lesbian Human Rights Commission, 1996.

56. Crofts, N; Deany, P. A global voice for harm reduction: the establishment of regional harm reduction networks. Drug and Alcohol Review, 1999; 18: 221-229.

57. Associação Brasileira de Redutores de Danos (ABORDA), Editorial, Boletim da ABORDA, n ${ }^{\circ} 2,1999$.

58. Group, WHO Consultation. Global surveillance of hepatitis C. Journal of Viral Hepatitis 1999:35-47.

59. Crofts, N: Tompson, S; Kaldor, J. Epidemiology of the hepatitis $C$ virus. Canberra: Commonwealth Department of Health and Aged Care of Australia, 1999.

60. Andrade T. "O nó da Seringa" in Mesquita, F \& Bastos, FI editores. Troca de Seringas: Drogas e AIDS, Ciência, Debate e Saúde Pública. Brasília, DF: Ministério da Saúde do Brasil, 1998: 153 - 161.

61. Carlini, E; Carlini-Cotrin, B; Silva-Filho, AR; Barbosa, MTS. Levantamento Nacional sobre o uso de psicotrópicos em estudantes de $1^{\circ}$ e $2^{\circ}$ graus 1989. São Paulo: CEBRID, 1990.

62. Carlini, E; Galduroz, JC; Noto, A; Nappo, S. I Levantamento Domiciliar Nacional Sobre Uso de Drogas Psicotrópicas. São Paulo: Universidade Federal de São Paulo; 2000.

63. Caiaffa, W; Bastos, FI. Usuários de drogas injetáveis e infecção pelo Vírus da Imunodeficiencia Humana: epidemiologia e perspectivas de intervenção. Revista Brasileira de Epidemiologia, 1998:190 - 202.

64. Szwarcwald, C; Bastos, FI; Gravato, N; Lacerda, R; Chequer, P; Castilho, EA. The relationship of illicit drug use to HIV infection among commercial sex workers in the city of Santos, Sao Paulo, Brazil. International Journal on Drug Policy 1998;9:427 - 436. 
65. Bastos, FI; Telles, PR; Bastos, W Jr; Strathdee, S. Higher frequency of commercial sex among crack smokers in a sample of injecting drug users, in Rio de Janeiro, Brazil. 12th World AIDS Conference. Poster - 23212, 1998.

66. Mesquita F; Bueno, R; Turienzo, G; Piconez, D; Haddad; I; Araujo, PJ. Diagnóstico Rápido e Pronta Resposta, in Mesquita F \& Seibel, S editores, Consumo de Drogas, desafios e perspectivas, São Paulo, HUCITEC, 2000: 123-160.

67. Caiaffa, W; Proietti, F; Marques, LF; Doneda, D; Carneiro-Proietti, A; Mingotti, S; Deslandes, S e Projeto Ajude-Brasil. Prevenção do HIV em Populações em UDIs e Projeto Ajude-Brasil, in Mesquita F \& Seibel, S editores, Consumo de Drogas, desafios e perspectivas, São Paulo, HUCITEC, 2000: 101-122.

68. Carvalho, H; Seibel, S; Santos, V; Sacomi, R; Finianos, A; Burattini,M; Massad, E. HIV and infections with related transmission in drug users of Brazil, particulary of crack abusers - analysis of morbidity and risk factors in behavior. In: XIII International Conference on AIDS; 2000; Durban South Africa; 2000.

69. Instituto Brasileiro de Geografia e Estatística (IBGE). Dados Preliminares do Censo 2000, on line no www.ibge.gov.br sobre agosto de 2000, em janeiro de 2001 .

70. DATASUS. Informações em Saúde, IDB 98: Ministério da Saúde do Brasil, on line no www.saude.gov.br sobre 1996, em maio de 2000.

71. IBOPE/CNI. Pesquisa de Opinião entre Brasileiros: principais problemas do Brasil: IBOPE/CNI, 2000.

72. World Health Organization. The World Health Report 2000. Geneva, WHO; on line no www.who.org, em setembro de 2000.

73. UNAIDS. Report on Global HIV/AIDS Epidemic. Geneva. UNAIDS; June 2000.

74. Hagan, H \& Des Jarlais, D. HIV and HCV Infection among Injecting Drug Users. The Mount Sinai Journal of Medicine 2000;67(5 \& 6):423-428.

75. Fonseca, MG \& Castilho, E. Os Casos de AIDS entre Usuários de Drogas Injetáveis. Brasil, 1980-1997. Boletim Epidemiológico de AIDS da 
Coordenação Nacional de DTS/AIDS, Ministério da Saúde, Brasília, junho a agosto de 1997.

76. Coordenação Nacional de DST/AIDS do Ministério da Saúde do Brasil. Boletim Epidemiológico. Ano XIII nº 1, Brasília, junho de 2000.

77. Santos, N; Kalichman, A; Granjeiro, A; Giana, C \& Munhoz, R. Heterossexual Transmission in women in São Paulo, Brasil. In: $\mathbf{X}$ International AIDS Conference. Yokohama, Japan, 1994.

78. Family Health International. Survey Measurements and Sampling Guidelines for Repeated Behavioral Surveys. Arlington, USA: Family Health International; 1999.

79. UNAIDS/WHO. Guidelines for Second Generation HIV Surveillance. Geneva: UNAIDS/WHO; 2000.

80. Watters, J; Biernacki, P. "Targeted Sampling: Options for the Study of Hidden Populations". Social Problems 1989;36:416-430.

81. Lohr S. In Sampling: Design and Analysis: Duxbury Press, 1999.

82. Lopes, C; Rodrigues, L \& Sichieri R "The Lack of Selection Bias in a Snowball Sampled Case-Control Study on Drug Abuse". International Journal of Epidemiology 1996; 25 (6): 1267-1270.

83. WHO. Carrying out HIV Sentinel Survaillance. New Delhi, India: Organização Mundial da Saúde, 1994.

84. Bastos FI. Os Riscos e a Singularidade. In: Bastos FI, ed. Ruína e Reconstrução; AIDS e Drogas Injetáveis na Cena Contemporânea. Rio de Janeiro: Relume Dumara, 1995:113-132.

85. Biernacki, P; Waldorf, D. "Snowball Sampling: Problems, Techniques and Chain-Referral Sampling". Sociological Methods and Research 1981;10:142-163.

86. Friedman, S; Neaigus, A; Jose, B; Curtis, R.; Des Jarlais, D. Networks and HIV: an introduction to social network analysis for harm reductionists. Journal on Drug Policy 1998;9:461-469.

87. Friedman, S; Neaigus, A; Jose, B; Curtis, R; Goldstein, M; Ildefonso, G; Rothenberg, R; Des Jarlais, D. Sociometric Risk Networks and Risk for HIV Infection. American Journal of Public Health 1997;87:1289-1296.75. 
88. Kish L. Special Techniques, Panel Studies and Change Designs. In: Survey Sampling. New York: John Wiley \& Sons, Inc; 1965. p. 469-477.

89. Des Jarlais, D; Friedman, S; Sotheran, J; Wenston, J; Marmor, M; Yancovitz, SR; Frank, B; Beatrice, S; Midvan, D. Continuity and change within an HIV epidemic: injecting drug users in New York City. Journal of the American Medical Association 1994;271(2):121-127.

90. Walters $\mathrm{J}$. The self reporting of cocaine use. Journal of the American Medical Association 1992; 268:2374-2375.

91. Rhodes, T; D, M; Hunter, G; Stimson, G. Continued risk behaviour among HIV positive drug injectors in London: implications for intervention. Addiction 1993;88:1553-1560.

92. Rhodes, T; M, M; Bueno, R; Myers, T; Hunter, G; Stimson, G. Differences in sexual behaviour and condom use among cocaine and opioid injectors in Santos, Toronto and London. International Journal on Drug Policy 1998;9:449-460.

93. Goldstein, DM. AIDS and Women in Brazil: the Emerging Problem. Social Science and Medicine 1994;39:919-929.

94. Scheper-Hughes N. An Essay: AIDS and Social Body. Social Science \& Medicine 1994;39:991-1003.

95. Giffin, K \& Lowndes, CM. Gender, sexuality, and the prevention of sexually transmissible diseases: a Brazilian study of clinical practice. Social science $\&$ Medicine 1999;48:283-292

96. Ventura-Felipe EMB, L. E.; Leme, B.; Santos, N.J.S.; Garcia, S.; Paiva, V.; Hearst, N. Risk perception and counselling among HIV-positive women in Sao Paulo, Brazil. International Journal of STD \& AIDS 2000;11:112-114.

97. Mesquita F; Kral, A.; Reingold, A.; Haddad, I.; Sanches, M.; Turienzo, G.; et al, R. Overdoses among Cocaine Drug Users in Brazil. Addiction, submetido em fevereiro de 2001.

98. Bastos F. Por uma Economia Simbólica das Trocas...De Seringas. In: Mesquita FB, FI, ed. Troca de Seringas : Drogas e AIDS; Ciência, Debate e Saúde Pública. Brasília, DF: Ministério da Saúde do Brasil, 1998:91-100. 
99. Lurie, P; Reingold, A. e colaboradores. The Public Health Impact of the Needle Exchange Programs in the United States and Abroad. Report para $a$ San Francisco and Berkeley: University of California and CDC; Outubro 1993

100. Des Jarlais, D; Friedman, S; Friedmann, P; Wenston, J; Sotheran, JL; Choopanya, $\mathrm{K}$ et all. HIV/AIDS-related behavior change among injecting drug users in different national settings. AIDS 1995;9:611-617.

101. Des Jarlais, D; Friedmann, P; Hagan, H; Friedman, S. The Protective Effect of AIDS-Related Behavioral Change among Injection Drug Users: A CrossNational Study. American Journal of Public Health 1996;86:1780-1785.

102. Des Jarlais, D; Hagan, H; Friedman, S; Friedmann, P; Goldberg, D; Frischer, $M$ et all. Preventing Epidemics of HIV-1 among Injecting Drug Users. In: Stimson GDJ, D; Ball, A, ed. Drug Injecting and HIV Infection: Global Dimensions and Local Responses. London: Taylor and Francis, 1998:183200.

103. Malliori, M; Zunzunegui, MV; Rodrigues-Arenas, A; Goldberg, D. Drug Injecting and HIV-1 Infection: Major Findings from the Multi-City Study. In: Stimson G; Ball, A; Des Jarlais, D., ed. "Global Perspectives on Drug Injecting" in Drug Injecting and HIV Infection: Global Dimensions and Local Response. London, UK: Taylor and Francis, 1998:58-75. 
VIII - Anexos

VIII.1 - Questionário do Estudo I, com consentimento informado. 


\title{
CENTRO DE REFERENCIA EM AIDS SANTOS
}

\author{
Consentimento para participar de pesquisa \\ (Versão em Português)
}

Estudo Piloto de Soroprevalença de HIV em Usuário de Drogas Endovenosas na cí dade de Santos - Estado de São Paulo - Brasil

\section{A- Proposta}

Dados internacionais demonstram importante relação entre o uso de Drogas ' Endovenosas e a infeç̧ão pelo virus da AIDS(HIV). Na cidade de Santos, mais ' de $50 \%$ dos casos têem esta forma de contaminação. Dr. Fábio Mesquita da Secre taria de Higiene e Saúde de Santos, esta estudando quantas pessoas que usem ' Droga E.V. estão contaminadas e quais os motivos da contaminação.

\section{B- Procedimentos}

Se eu concordar em participar deste estudo deverei:

1- Responder um questionário sobre: meu histórico de saúde, meu comporta mento sexual e minha história de uso de Drogas.

2- Serão colhidos $10 \mathrm{ml}$ de meu sangue para serem testados. Serão realiza dos ELISA e Western-Blot.

3- Eu receberei os resultados dos exames.

4- Eu receberei 200,00 cruzeiros no início e mais 500,00 cruzeiros quando' voltar para o resultado.

5- A entrevista será em torno de 20 minutos.

\section{C- Riscos e Desconfortos}

Existe uma pequena probabilidade de infecção pela coleta de sangue, embora seja extremamente raro. Se houver qualquer problema, terei acesso à tratamento adequado no Serviço de Saúde Pública.

\section{D- Confidencialidade}

Eu receberei pessoalmente os resultados de meus exames laboratoriais. Meus dados pessoais serão guardados pelo Dr. Fábio Mesquita em arquivo seguro. Meus dados serão arquivados pelo nome de meu pai e minha mãe e pela data.' de meu nascimento. Os dados deste estudo poderão ser publicados sem a pu blicação dos nomes dos pesquisados. Embora todo esforço seja feito para a preservação da confidencialidade é possivel que a privacidade seja perdi da.

\section{E- Benefícios}

Se o diagnóstico de infecção por HIV for positivo, terei acesso ao trata mento no Centro de Referência em AIDS 


\section{F- Dúvidas}

Se houver qualquer dúvida sobre a participação neste estudo, poderei escla rece-la com o Dr. Fábio Mesquita pelo telefone 39.6060 .

G- Consentimento

A participação neste estudo é voluntária. Eu tenho direito em qualaner mo mento desta pesquisa de desistir, sem prejuízo de meus cuidados de saúde. Eu li este formulário e recebi as explicações necessárias do Dr. Fábio Mes quita ou - Para consentir minha pa

ticipação, assinarei este formulário.

Assinatura Entrevistado

Assinatura do Entrevistador

Assinatura de testemunha (opcional)
Santos, 1 $/$

Santos,

Santos, ' /

IRB APROVAL NUMBER - UCSF - H 924-06395-OI 
DROGA INJETÁVEL E RISCO DE INFECÇ̃̃O POR HIV

SEÇÃO 1. INFORMAÇÕES SOBRE A ENTREVISTA

\begin{tabular}{|c|c|}
\hline 101 & ENTREVISTA No \\
\hline 102 & Número de identificação próprio ao país $\quad \square \square$ \\
\hline 103 & Número de código do entrevistador \\
\hline 104 & Data da entrevista Dia Mês \\
\hline 105 & $\begin{array}{l}\text { Aonde está sencio realizada } \\
\text { a entrevista? }\end{array}$ \\
\hline 106 & INÍCIO DA ENTREVISTA \\
\hline
\end{tabular}




\section{DROGA INJETÁVEL E RISCO DE INFECCÃ̃ POR HIV}

\section{INFORMAÇÕES ESSENCIAIS}

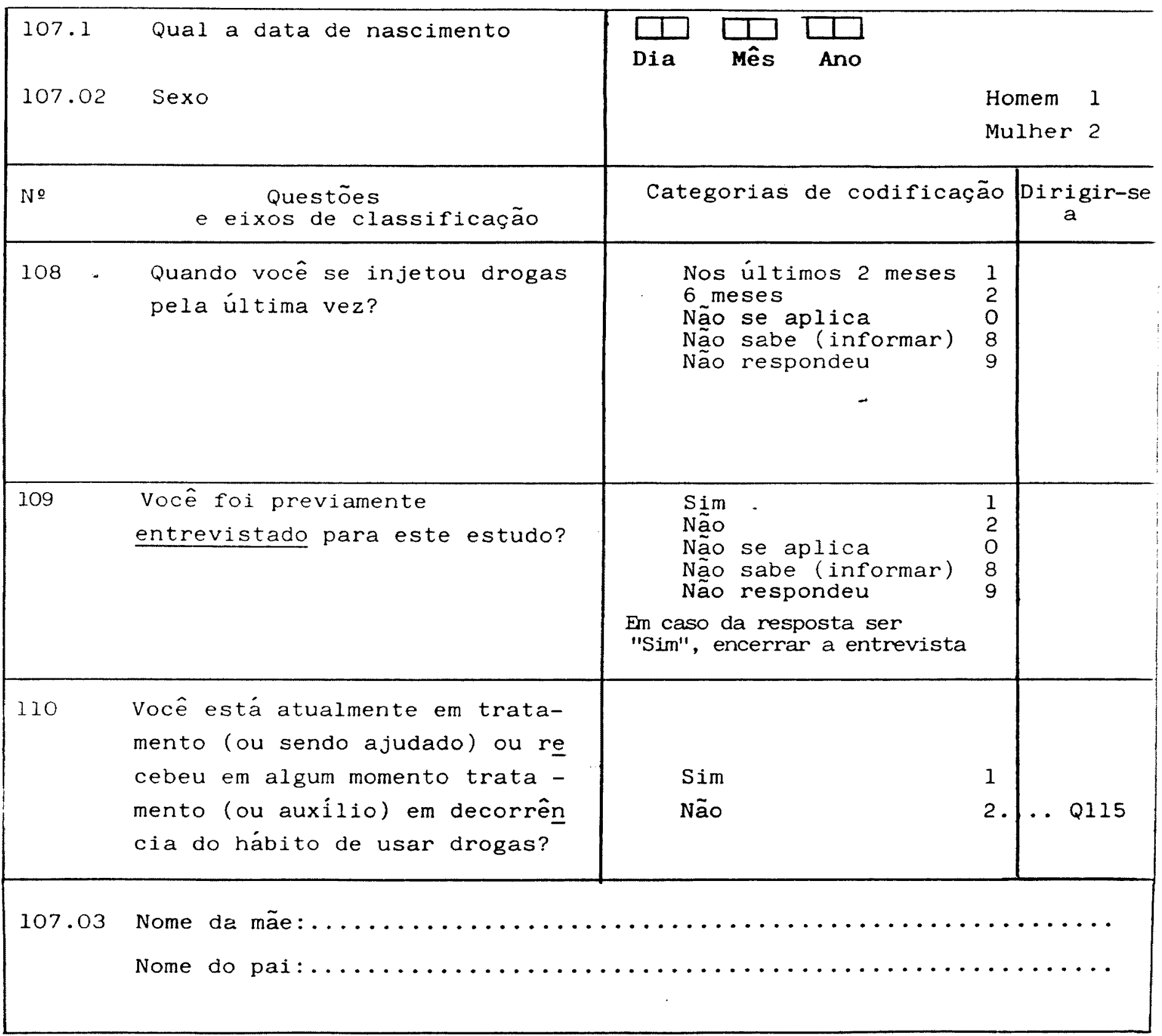




\section{DROGAS INJETÁVEIS E RISCO DE INFECÇÃO POR HIV}

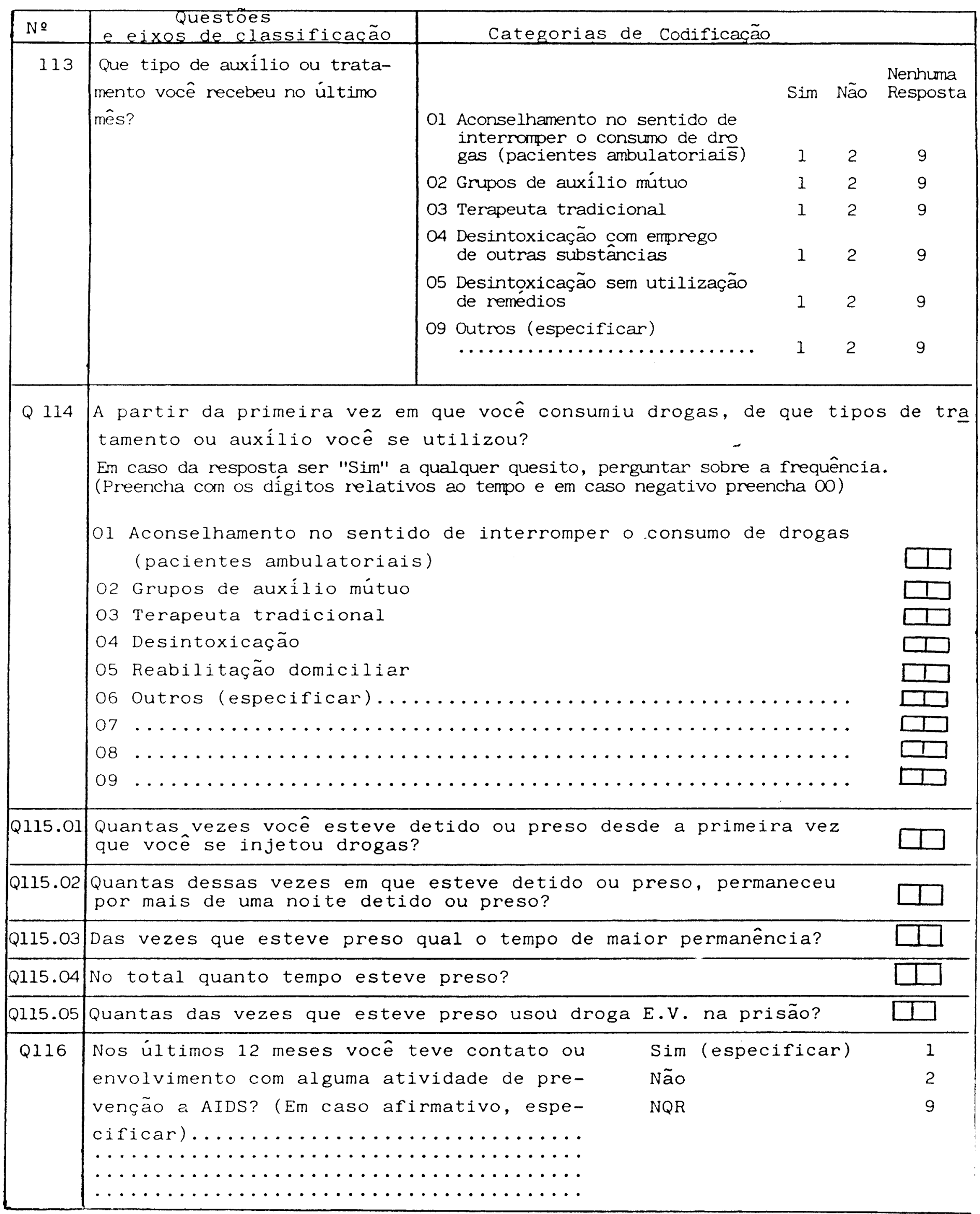




\section{DROGAS INJETÁVEIS E RISCO DE INFECÇÃO POR HIV}

\section{SEÇÃO 2 : CARACTERÍSTICAS DEMOGRÁFICAS}

Eu gostaria de perguntar-lhe agora acerca dos seus dados básicos, de você e os de sua familia

\begin{tabular}{|c|c|c|c|}
\hline NNo & $\begin{array}{ll} & \text { QUESTÕES } \\
\text { E EIXOS DE } & \text { CLASSIFICAÇÃO }\end{array}$ & CATEGORIA DE CODIFICAÇÃO & $\underset{\tilde{A}}{\text { DIRIGIR-S }}$ \\
\hline Q201 & Em que pais você nasceu? & $\begin{array}{l}\text { No caso do entrevsitado ter } \\
\text { nascido no país onde se dá } \\
\text { entrevista }\end{array}$ & Q203 \\
\hline Q202 & $\begin{array}{l}\text { Em que ano você chegou nes } \\
\text { te pais? }\end{array}$ & $\begin{aligned} & \square \\
& \text { Código 0000, caso não seja alicável }\end{aligned}$ & \\
\hline Q203.01 & $\begin{array}{l}\text { Essa cidade é seu local habi } \\
\text { tual de residencia? }\end{array}$ & $\begin{aligned} \operatorname{Sim} & 1 . \\
\text { Não } & 2 . \\
\text { nenhuma resposta } & 3\end{aligned}$ & $\begin{array}{l}. Q 203.003 \\
. Q 203.02\end{array}$ \\
\hline Q203.03 & Onde você mora habitualmente? & $\begin{array}{l}\text { Escreva } \ldots \ldots \ldots \ldots \text { INENUM se o eritevistado } \\
\text { não residir em nenhum lugar. }\end{array}$ & \\
\hline Q203.03 & $\begin{array}{l}\text { Há quanto tempo você mora } \\
\text { nesta cidade? }\end{array}$ & 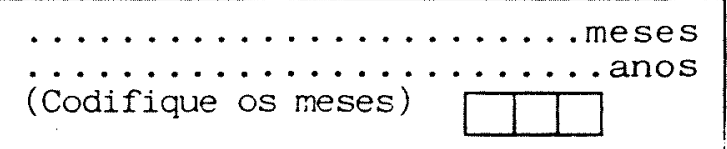 & \\
\hline Q203.04 & Bairro em que reside: & $\ldots \ldots \ldots \ldots \ldots \ldots \ldots$ & \\
\hline Q204 & $\begin{array}{l}\text { Quantos anos vocé tinha quan } \\
\text { do interrompeu seus estudos } \\
\text { regulares }\end{array}$ & Anos de idade & \\
\hline Q205 & $\begin{array}{l}\text { Quantos anos completos de ' } \\
\text { educaça regular você cursou? }\end{array}$ & (Anos de escolaridade regular) & \\
\hline Q206 & $\begin{array}{l}\text { Ao longo dos últimos } 6 \text { meses, } \\
\text { qual sua principal fonte de } \\
\text { renda e sustento? }\end{array}$ & $\begin{array}{lr}\text { Empregado com salário regular } & 01 \\
\text { Desempregado sem benefício estatal } \\
\text { regular } & 02 \\
\text { Trabalho temporário } & 03 \\
\text { Em beneficio } & 04 \\
\text { Contando com a renda do cônjuge ou } \\
\text { parente } & 05 \\
\text { Seguro desemprego } & 06 \\
\text { Autônomo } & 07 \\
\text { Nenhuma (isto é rendas integralmen } \\
\text { te ilegeis) } & 08 \\
\text { Outros (especificar)............. } 09 \\
\text { Não se aplica } & 00 \\
\text { Não sabe } & 88 \\
\text { Não respondeu } & 99\end{array}$ & \\
\hline
\end{tabular}




\section{DROGA INJETÁVEL E RISCO DE INFECÇÃO POR HIV}

\begin{tabular}{|c|c|c|c|}
\hline No & $\begin{array}{c}\text { QUESTÕES } \\
\text { E EIXOS DE CLASSIFICAÇÃO }\end{array}$ & CATEGORIAS DE CODIFICAÇÃO & $\begin{array}{l}\text { DIRIGIR-S } \\
\grave{A}\end{array}$ \\
\hline Q207 & $\begin{array}{l}\text { Qual o seu "status" marital } \\
\text { atual ? Com isso eu quero" } \\
\text { saber se vocé é: }\end{array}$ & $\begin{array}{lr}\text { Cașado } & 1 \\
\text { Viuvo (a) } & 2 \\
\text { Separado (a) } & 3 \\
\text { Divorciado (a) } & 4 \\
\text { Nunca casou/solteiro(a) } & 5 \\
\text { Amasiado } & 6 \\
\text { NQR } & 9\end{array}$ & $\begin{array}{r}\ldots \text { Q209 } \\
\ldots \text { Q209 } \\
\ldots \text { Q209 } \\
\ldots Q 209 \\
\ldots \text { Q }\end{array}$ \\
\hline Q208 & $\begin{array}{l}\text { você e seu/sua esposo/a vi- } \\
\text { vem juntos no mmomento? }\end{array}$ & $\begin{array}{l}\text { Sim } \\
\text { Não } \\
\text { NQR }\end{array}$ & \\
\hline Q209 & $\begin{array}{l}\text { Você está vivéndo com alguém } \\
\text { com quem mantém relações se- } \\
\text { xuais? }\end{array}$ & $\begin{array}{l}\text { Sim } \\
\text { Não } \\
\text { NQR }\end{array}$ & $\ldots Q 211$ \\
\hline Q210 & $\begin{array}{l}\text { Essa pessoa é do seu próprio } \\
\text { sexo ? }\end{array}$ & $\begin{array}{ll}\text { Sim } & 1 \\
\text { Não } & 2 \\
\text { NQR } & 9\end{array}$ & \\
\hline Q211 & $\begin{array}{l}\text { Ao longo dos últimos } 6 \text { meses, } \\
\text { aonde você viveu a maior par } \\
\text { te do tempo? }\end{array}$ & 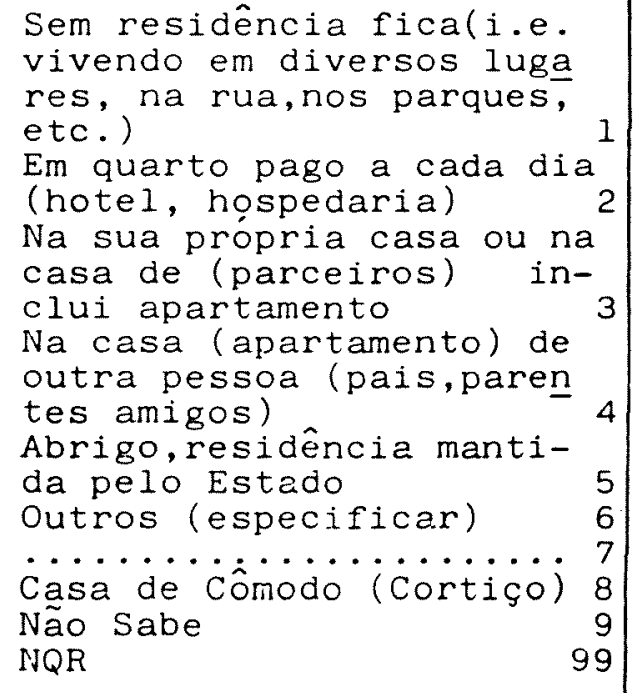 & \\
\hline Q212 & $\begin{array}{l}\text { Quantos filhos, sejam eles ' } \\
\text { frutos de união legal, natu- } \\
\text { rais ou adotivos você tem? }\end{array}$ & & \\
\hline Q213 & $\begin{array}{l}\text { Você pensa em ter um (mais } \\
\text { que um) filho? }\end{array}$ & $\begin{array}{ll}\text { Sim } & 1 \\
\text { Não } & 2 \\
\text { A entrevistada ou a par } & \\
\text { ceira do entrevistạdo T } & \\
\text { está no momento grávida? } & 3 \\
\text { Não sabe } & 8 \\
\text { NQR } & 9\end{array}$ & \\
\hline
\end{tabular}




\section{DROGAS INJETÁVEIS E RISCO DE INFECCÃ̃O POR HIV}

\section{SEÇÃO 3: CONSUMO DE DROGAS}

Eu gostaria de perguntar a você agora, algumas questões acerca do uso de drog: injetável.

\begin{tabular}{|l|l|c|c|}
\hline No & E EIXOS DE CLASSIFICAÇÃO & CATEGORIAS DE CODIFICAÇÃO \\
\hline Q301 & $\begin{array}{l}\text { Quantos anos você tinha quando se } \\
\text { injetou drogas pela primeira vez? }\end{array}$ & anos \\
\hline Q302 & $\begin{array}{l}\text { Em quantos dos últimos seis meses, } \\
\text { você se injetou drogas? }\end{array}$ & $\square$ \\
\hline
\end{tabular}

Agora perguntarei a você algumas questōes sobre drogas que você consumiu nos ú timos 6 meses. Para cada droga que eu mencionar, perguntarei em primeiro lugar se você a utilizou, em segundo lugar, se a utilização se deu por via injetável em terceiro lugar com qual frequência você se injetou.

\begin{tabular}{|c|c|c|c|c|c|c|c|c|c|c|c|}
\hline \multirow[t]{3}{*}{ Q303 } & \multicolumn{8}{|c|}{$\begin{array}{l}\text { Primeiro no caso nome da droga repita para cada droga: } \\
\text { Você a utilizou? } \\
\text { Você a injetou? } \\
\text { Nos meses que você a injetou, o fez com que frequência? } \\
\text { MostraR A TABELA "A" }\end{array}$} & \\
\hline & Nome da droga & \multicolumn{3}{|c|}{ Uso } & \multicolumn{3}{|c|}{ Injetável } & Injetou com que frequência & & & \\
\hline & 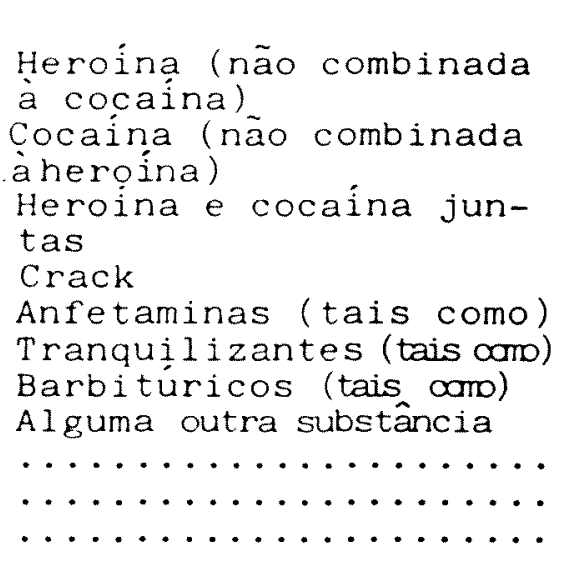 & $\begin{array}{l}2 \\
2 \\
2 \\
2 \\
2\end{array}$ & $\begin{array}{l}5 \\
1 \\
1 \\
\\
1 \\
1 \\
1 \\
1 \\
1 \\
1 \\
1 \\
1\end{array}$ & $\begin{array}{r}\text { NR } \\
9 \\
9 \\
\\
\\
9 \\
9 \\
9 \\
9 \\
9 \\
9 \\
9 \\
9\end{array}$ & $\begin{array}{l}2 \\
2 \\
2 \\
2 \\
2 \\
2 \\
2 \\
2\end{array}$ & $\begin{array}{l}\text { S } \\
1 \\
1 \\
1 \\
1 \\
1 \\
1 \\
1 \\
1 \\
1 \\
1 \\
1\end{array}$ & $\begin{array}{r}\text { NR } \\
9 \\
9 \\
\\
9 \\
9 \\
9 \\
9 \\
9 \\
9 \\
9 \\
9\end{array}$ & 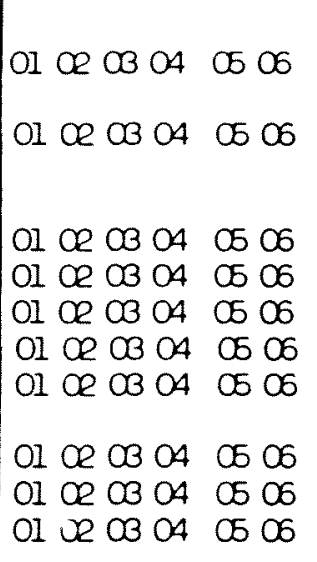 & 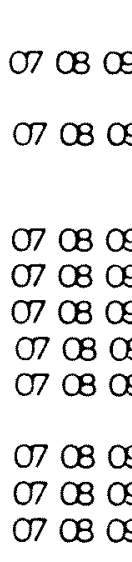 & $\begin{array}{ll}\text { NA } & \alpha \\
9 & \alpha \\
& \alpha \\
9 & \alpha \\
9 & \alpha \\
9 & \alpha \\
9 & \alpha \\
9 & \alpha \\
9 & \alpha \\
9 & \alpha \\
9 & \alpha\end{array}$ & $\begin{array}{ll}A & N R \\
0 & 99 \\
D & 99 \\
& \\
D & 99 \\
D & 99 \\
D & 99 \\
\infty & 99 \\
\infty & 99 \\
\infty & 99 \\
\infty & 99 \\
\infty & 99\end{array}$ \\
\hline Q303.12 & $\begin{array}{l}\text { Para terminar, vocé ' } \\
\text { usou maconha ou haxixe } \\
\text { nos ultimos } 6 \text { meses? }\end{array}$ & & & & & & & $\begin{array}{l}\text { Si⿺ } \\
\text { Nã } \\
\text { Não se aplic } \\
\text { Não sabe } \\
\text { Não respondel }\end{array}$ & $\begin{array}{l}1 \\
2 \\
0 \\
8 \\
9\end{array}$ & & \\
\hline
\end{tabular}




\section{DROGAS INJETÁVEIS E RISCO DE INFECÇÃO POR HIV}

Perguntarei agora acerca do seu consumo global de drogas injetáveis nos últimos 6 meses.

\begin{tabular}{|c|c|c|}
\hline No & $\begin{array}{c}\text { QUESTÕES } \\
\text { E EIXOS DE CLASSIFICAÇÃO }\end{array}$ & CATEGORIAS DE CODIFICAÇÃO \\
\hline Q304 & $\begin{array}{l}\text { Nos meses em que você injetou } \\
\text { drogas,com qual frequência } \\
\text { você o fez? } \\
\text { MOSTRAR A TABELA "A" }\end{array}$ & 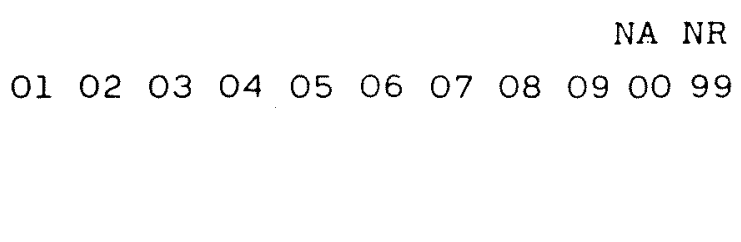 \\
\hline Q305 & $\begin{array}{l}\text { Em quantos dias ao longo de um } \\
\text { mês caracteristico do seu con- } \\
\text { sumo de drogas injetáveis você } \\
\text { faz uso delas? }\end{array}$ & cias \\
\hline Q306 & $\begin{array}{l}\text { Quantas vezes ao longo de um } \\
\text { dia caracterśitico você se } \\
\text { injeta drogas de modo habi- } \\
\text { tual? }\end{array}$ & \\
\hline
\end{tabular}




\section{DROGAS INJETÁVEIS E RISCO DE INFECÇÃO POR HIV}

\section{SEÇÃO 4: COMPARTILHAMENTO DE AGULHAS E SERINGAS}

a seção eu gostaria de perguntar a você algumas questões sobre a auto-apli ào de injeções e estou interessado também no numero de vezes que você se in

ou se utilizando de uma seringa e agulha já usadas antes por outras pessoas. nalmente eu gostaria de perguntar a você soḅre as ocasióes em que voce permi -u a outros utilizarem agulhas e seringas após terem sido usadas por vocé.

\begin{tabular}{|c|c|c|c|c|c|c|}
\hline No & E EIXOS DEQUESTSTESFICAÇÃO & \multicolumn{2}{|l|}{ CATEGORIAS DE CODIFICAÇÃO } & \multicolumn{3}{|c|}{$\underset{\tilde{A}}{D I R I G I R-\varepsilon}$} \\
\hline Q401 & $\begin{array}{l}\text { Quando vocé se injetou nos últi- } \\
\text { mos.6 meses, quantas vezes o fez } \\
\text { com agulhas e seringas dadas, em- } \\
\text { prestadas, vendidas a você por al } \\
\text { guém (incluinco seu parceiro/a)? } \\
\text { MOSTRAR A TABELA "A" }\end{array}$ & $\begin{array}{l}\text { Nunca/nenhum } \\
\text { Menos de una vez ao mês } \\
\text { Uma a trés vezes ao mês } \\
\text { Cerca de una vez por } \\
\text { semana } \\
\text { Duas a três vezes por } \\
\text { semana } \\
\text { Quatro a seis vezes por } \\
\text { semana } \\
\text { Cerca de una vez por dia } \\
\text { Duas a trés vezes por dia, } \\
\text { quase todo dia } \\
\text { Quatro ou mais vezes por } \\
\text { dia quase todo o dia } \\
\text { Não se aplica } \\
\text { Não sabe } \\
\text { Não respondeu }\end{array}$ & $\begin{array}{l}01 \\
02 \\
03 \\
04 \\
05 \\
06 \\
07 \\
08 \\
09 \\
00 \\
88 \\
99\end{array}$ & $\ldots Q 4 C$ & & \\
\hline Q402 & $\begin{array}{l}\text { Quando você se injetou utilizan } \\
\text { do-se de agulhas e seringas usâa } \\
\text { das nos ûltimos } 6 \text { meses, de } \\
\text { quem você as obteve? }\end{array}$ & 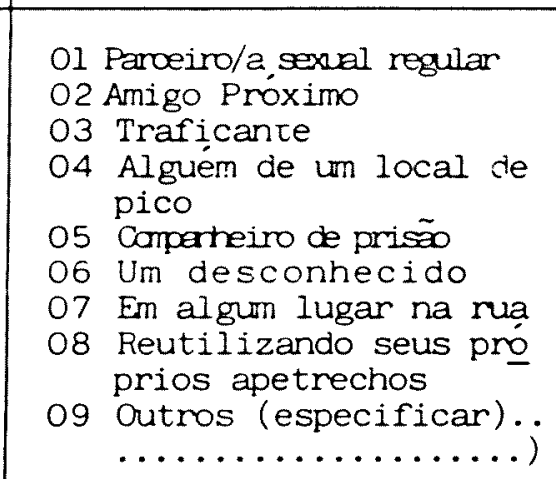 & $\begin{array}{c}\text { Sim } \\
1 \\
1 \\
1 \\
1 \\
1 \\
1 \\
1 \\
1 \\
1 \\
1\end{array}$ & $\begin{array}{l}\text { Nao } \\
2 \\
2 \\
2 \\
2 \\
2 \\
2 \\
2 \\
2 \\
2 \\
\end{array}$ & $\begin{array}{l}\text { INA } \\
0 \\
0 \\
0 \\
0 \\
0 \\
0 \\
0 \\
0 \\
0 \\
0 \\
0\end{array}$ & $\begin{array}{c}\text { AR } \\
9 \\
9 \\
9 \\
\\
9 \\
9 \\
9 \\
9 \\
9 \\
9\end{array}$ \\
\hline Q403 & $\begin{array}{l}\text { Opcional } \\
\text { Se a resposta dor SIM a alguma } \\
\text { das perguntas acima, perguntar } \\
\text { quantas vezes e } \\
\text { MOSTRE TABELA "B" } \\
\text { Das vezes em que você se injetou } \\
\text { utilizando agulhas e seringas } \\
\text { usadas nos ultimos } 6 \text { meses, com } \\
\text { que frequência elas vieram de: }\end{array}$ & 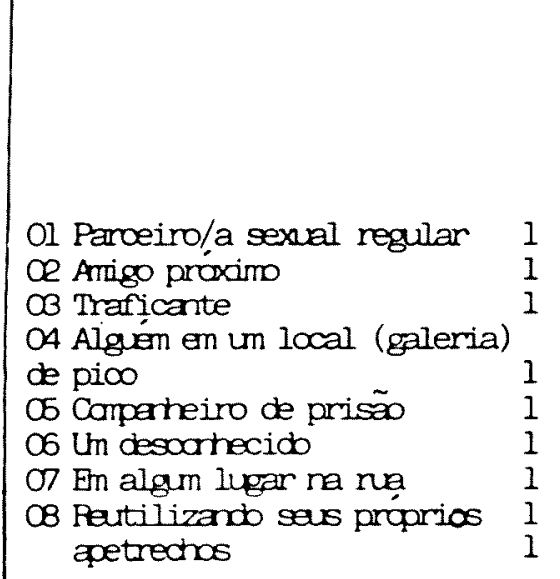 & $\begin{array}{lll}2 & 3 & 4 \\
2 & 3 & 4 \\
2 & 3 & 4 \\
2 & & \\
2 & 3 & 4 \\
2 & 3 & 4 \\
2 & 3 & 4 \\
2 & 3 & 4 \\
2 & 3 & 4 \\
2 & 3 & 4\end{array}$ & 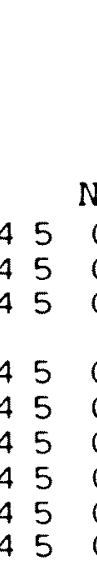 & $\begin{array}{l}\text { NA } \\
0 \\
0 \\
0 \\
0 \\
0 \\
0 \\
0 \\
0 \\
0 \\
0\end{array}$ & $\begin{array}{l}\text { NQR } \\
9 \\
9 \\
9 \\
9 \\
9 \\
9 \\
9 \\
9 \\
9\end{array}$ \\
\hline Q404 & $\begin{array}{l}\text { Número de pessoas diferentes } \\
\text { que lhe fomeceram agulhas e seringas } \\
\text { já usadas nos últimos } 6 \text { meses. }\end{array}$ & & & & & \\
\hline
\end{tabular}


DROGAS INJETÁVEIS E RISCO DE INFECÇÃOO POR HIV

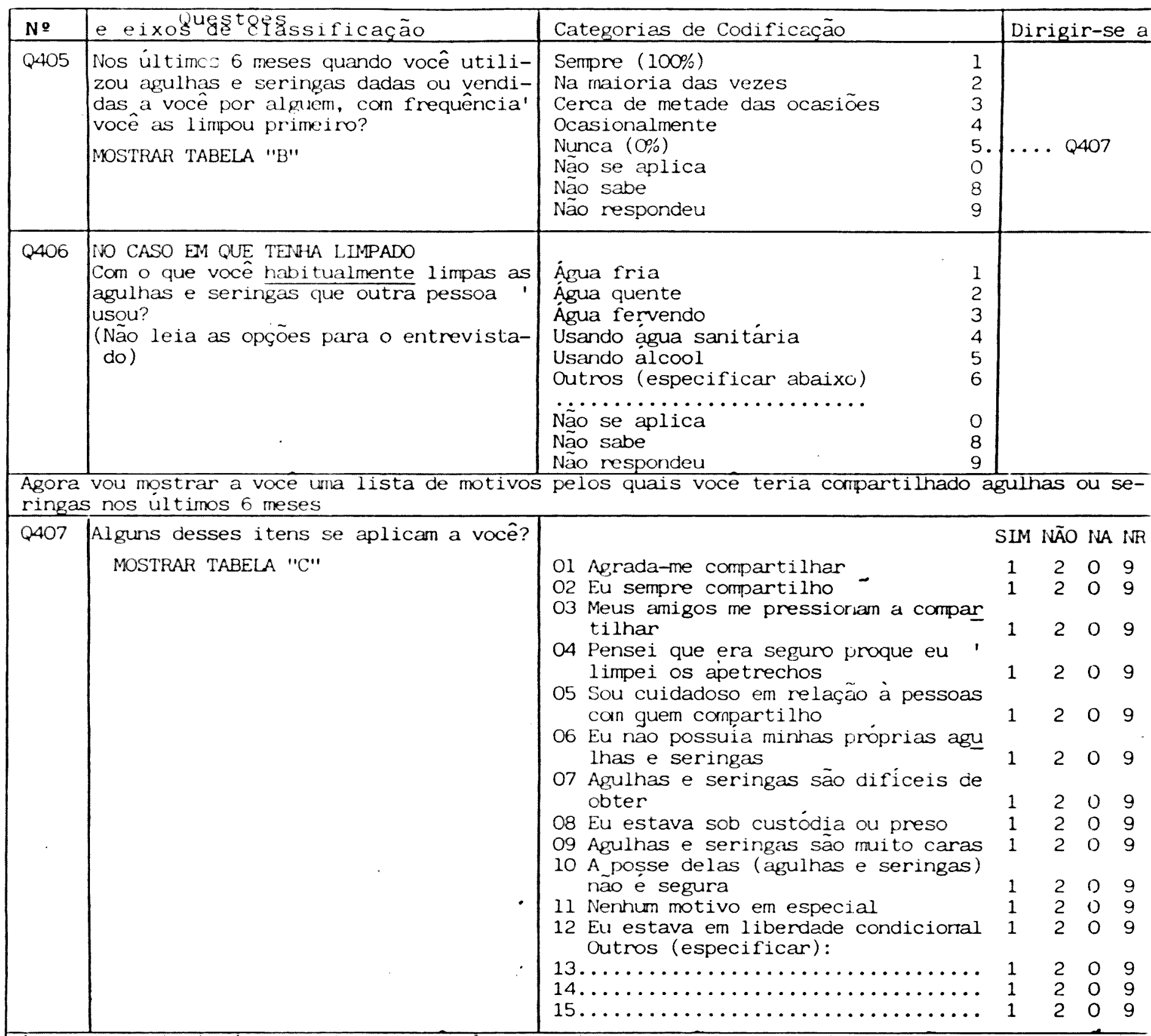

Agora eu gostaria de perguntar a voce algumas outras questoes acerca das ocasioes em que voce deu ou vendeu suas agulhas e seringas para alguem

\begin{tabular}{|c|c|c|c|c|}
\hline$Q 408$ & $\begin{array}{l}\text { Quando você se injetou nos últimos } 6 \text { ' } \\
\text { meses com que frequêricia você deu, em } \\
\text { prestou ou vendeu para alguém uma agu } \\
\text { lha ou seringa já utilizada? } \\
\text { MOSTRE A TABELA "A" }\end{array}$ & $\begin{array}{l}\text { Nunca/nenhum } \\
\text { Menos de uma vez ao mês } \\
\text { Um a três vezes ao mês } \\
\text { Cerca de una.vez por semana } \\
\text { Duas a trés vezes por semana } \\
\text { Quatro a seis vezes por semana } \\
\text { Cerca de uma vez por dia } \\
\text { Duas a três vezes por dia, quase } \\
\text { todo o dia } \\
\text { Quatro ou mais vezes por dia, qua } \\
\text { se todo o dia } \\
\text { Năo se aplica } \\
\text { Năo sabe } \\
\text { Năo respondeu }\end{array}$ & $\begin{array}{l}01 \\
02 \\
03 \\
04 \\
05 \\
06 \\
07 \\
08 \\
09 \\
00 \\
88 \\
99\end{array}$ & $\ldots . Q 412$ \\
\hline
\end{tabular}


DROGAS INJETÁVEIS E RISCO DE INFECCÄO POH HIV

\begin{tabular}{|c|c|c|c|c|c|c|}
\hline$N \cong$ & e eixos Questegssificacão & Categorias de Codificacão & & & & \\
\hline Q409 & $\begin{array}{l}\text { Quando vocë deu, emprestou, ou vendeu para } \\
\text { alguém uma agulha ou seringa, nos útlimos } \\
6 \text { meses, foi sempre para: }\end{array}$ & $\begin{array}{l}\text { Parceiro/a, sexual regular } \\
\text { Amigo/a próximo/a } \\
\text { Traficante } \\
\text { Alguém num local de pico } \\
\text { Um cómpanheiro de prisão } \\
\text { Alguém que você não conthece bem }\end{array}$ & & $\begin{array}{l}\text { Sim } \\
1 \\
1 \\
1 \\
1 \\
1 \\
1\end{array}$ & & $\begin{array}{l}\sqrt{20} \mathrm{o} \\
2 \\
2 \\
2 \\
2 \\
2 \\
2\end{array}$ \\
\hline Q410 & $\begin{array}{l}\text { Das vezes que você deu, emprestou ou ven- } \\
\text { deu a alguem una agulha ou seringa usada ' } \\
\text { nos últimos } 6 \text { meses, com que frequencia vo } \\
\text { cê as deu para: } \\
\text { OPCIONAL: } \\
\text { Se a resposta for SiM a alguma das questões } \\
\text { acima, perguntar con que frequência. } \\
\text { MOSTRE A TABELA "B" }\end{array}$ & $\begin{array}{ll}\text { Parceiro/a sexual regular } & 1 \\
\text { Amigo/a proximo/a } & 1 \\
\text { Traficante } & 1 \\
\text { Alguém num local de pico } & 1 \\
\text { Um companheiro de prisão } & 1 \\
\text { Alguem que você não contrece } & \\
\text { bem } & 1\end{array}$ & $\begin{array}{ll}2 & 3 \\
2 & 3 \\
2 & 3 \\
2 & 3 \\
2 & 3 \\
2 & 3\end{array}$ & $\begin{array}{ll}4 & 5 \\
4 & 5 \\
4 & 5 \\
4 & 5 \\
4 & 5 \\
4 & 5\end{array}$ & $\begin{array}{l}\text { NA } \\
0 \\
0 \\
0 \\
0 \\
0\end{array}$ & \\
\hline Q411 & $\begin{array}{l}\text { A quantas pessoas diferentes no total você } \\
\text { deu, emprestou ou vendeu agulhas e seringas } \\
\text { usadas nos últimos } 6 \text { meses? }\end{array}$ & & & & & \\
\hline Q412 & $\begin{array}{l}\text { Nos últimos } 6 \text { meses cono você obteve agu - } \\
\text { lhas e seringas novas (que nurica foram usa } \\
\text { das antes)? } \\
\text { (Não leia os itens para o entrevistado, co } \\
\text { difique mais de um item se necessario. T } \\
\text { Pergunte apenas utilizando "alguma coisa' } \\
\text { mais) }\end{array}$ & 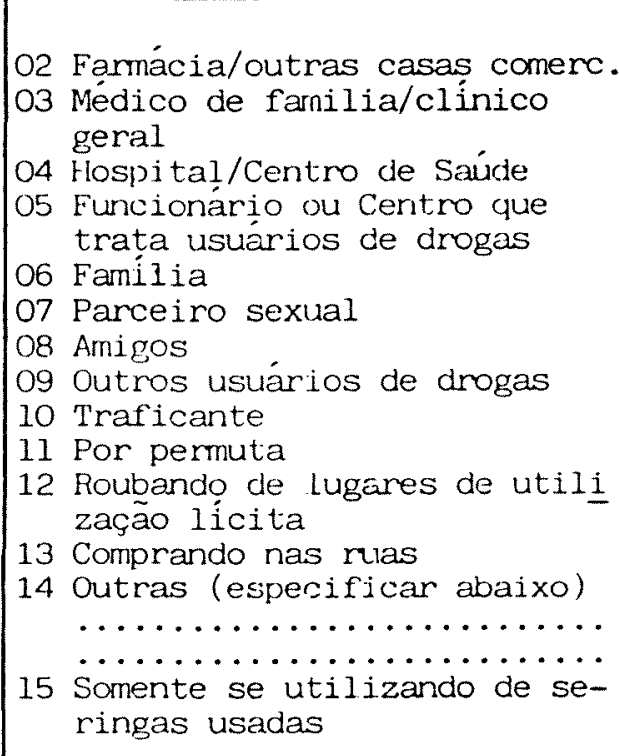 & $\begin{array}{l}\text { SIM } \\
1 \\
1 \\
1 \\
1 \\
1 \\
1 \\
1 \\
1 \\
1 \\
1 \\
1 \\
1 \\
1\end{array}$ & $\begin{array}{c}\text { NÃO } \\
2 \\
2 \\
2 \\
2 \\
2 \\
2 \\
2 \\
2 \\
2 \\
2 \\
2 \\
2 \\
2\end{array}$ & $\begin{array}{l}\text { NA } \\
0 \\
0 \\
0 \\
0 \\
0 \\
0 \\
0 \\
0 \\
0 \\
0 \\
0 \\
0 \\
0 \\
0 \\
0\end{array}$ & $\begin{array}{l}\text { lil } \\
9 \\
9 \\
9 \\
9 \\
9 \\
9 \\
9 \\
9 \\
9 \\
9 \\
9 \\
9 \\
9\end{array}$ \\
\hline Q413 & $\begin{array}{l}\text { Se existirem várias formas, qual a mais } \\
\text { importante dentre elas? }\end{array}$ & $\begin{array}{l}\square \square \\
\text { (Ver categorias cle codificaçã }\end{array}$ & $\mathrm{o}$ em & Q41: & & \\
\hline Q414 & $\begin{array}{l}\text { O que você acha de existirem pontos de } \\
\text { troca de seringas? (Onde se trocam serin- } \\
\text { gas usadas por novas; distribui material } \\
\text { para limpar seringas; distribui camisinha } \\
\text { e folhetos informativos }\end{array}$ & $\begin{array}{cccc}\text { Sim } & \text { Não } & \text { NIA } & \text { NR } \\
1 & 2 & 0 & 9\end{array}$ & & & & \\
\hline
\end{tabular}




\section{DROGAS INUETÁVEIS E RISCO DE INFEOCÃ̃O POR HIV}

\section{SEÇÃO 5: COMPORTAMENTO SEXUAL}

Eu gostaria agora de perguntar a você algumas questões acerca de suas relações sexuais com seu/sua parceiro/a, parceiros/as eventuais e clientes. Você pode julgar que algumas, destas questões são denatureza estritamente pessoal, mas lembre-se de que nós estamos fazendo a todos que participam deste estudo. Algu mas delas podem näo se aplicar ao seu caso. Todas as respostas constituem mate rial estritamente confidencial.

\begin{tabular}{|c|c|c|c|}
\hline NN 9 & $\begin{array}{c}\text { QUESTÕES } \\
\text { E EIXOS DE CLASSIFICAÇÃO }\end{array}$ & CATEGORIA DE CODIFICAÇÃO & DIRIGIR-SE \\
\hline Q501 & $\begin{array}{l}\text { Com que frequência você prati- } \\
\text { cou ato sexual, (vaginal, anal, } \\
\text { oral) com alguém do sexo opos } \\
\text { to nos ultimos } 6 \text { meses? } \\
\text { MOSTRE A TABELA "A" }\end{array}$ & $\begin{array}{l}\text { Nunca/nenhum } \\
\text { Menos de uma vez ao mês } \\
\text { Uma a três vezes ao mês } \\
\text { Cerca de uma vez por semana } \\
\text { Duas a três vezes por semana } \\
\text { Quatro a seis vezes por semana } \\
\text { Cerca de una vez por dia } \\
\text { Duas a três vezes por dia, } \\
\text { quase todo dia } \\
\text { Quatro ou mais vezes por dia, } \\
\text { quase todo dia } \\
\text { Näo se aplica } \\
\text { Näo sabe } \\
\text { Não respondeu }\end{array}$ & $\begin{array}{l}01 \\
02 \\
03 \\
04 \\
05 \\
06 \\
07 \\
08 \\
09 \\
00 \\
88 \\
99\end{array}$ \\
\hline \multicolumn{4}{|c|}{$\begin{array}{l}\text { Se a resposta for INNCA e o entrevistado for homem } \\
\text { Se a resposta for NUNCA e o entrevistado for mulher }\end{array}$} \\
\hline \multicolumn{4}{|c|}{$\begin{array}{l}\text { As questöes abaixo versam sobre a atividade sexual com seu parceiro/a princi- } \\
\text { pal do sexo oposto. Por parceiro principal eu quero me referir a alguem que é } \\
\text { o seu mais importante parceiro/a sexual regular do sexo oposto. }\end{array}$} \\
\hline Q502 & $\begin{array}{l}\text { Nos ultimos } 6 \text { meses, com que } \\
\text { frequência você teve relação } \\
\text { sexual vaginal com seu/sua } \\
\text { principal parceiro/a do sexo } \\
\text { oposto? } \\
\text { MOSTRE A TABELA "A" }\end{array}$ & $\begin{array}{l}\text { Nunca/nenhum } \\
\text { Menos de uma vez ao mês } \\
\text { Uma a três vezes ao mês } \\
\text { Cerca de uma vez por semana } \\
\text { Duas a três vezes por semana } \\
\text { Quatro a seis vezes por semana } \\
\text { Cerca de una vez por dia } \\
\text { Duas a três vezes por dia, } \\
\text { quase todo o dia } \\
\text { Quatro ou mais vezes por dia, } \\
\text { quase todo o dia } \\
\text { Não se aplica } \\
\text { Não sabe } \\
\text { Năo respondeu }\end{array}$ & $\begin{array}{l}01 \\
02 \\
03 \\
04 \\
05 \\
06 \\
07 \\
08 \\
09 \\
09 \\
08 \\
99\end{array}$ \\
\hline Q503 & $\begin{array}{l}\text { Nos úlitimos } 6 \text { meses, com que } \\
\text { frequência você teve relação } \\
\text { sexual anal com seu/sua prin } \\
\text { cipal parceiro/a do sexo } \\
\text { opos:o? } \\
\text { MOSTRE A TABELA "A" }\end{array}$ & $\begin{array}{l}\text { Nunca/nenhum } \\
\text { Menos de uma vez por mês } \\
\text { Uma a tres vezes ao mês } \\
\text { Cerca de una vez por semana } \\
\text { Duas a trés vezes por semana } \\
\text { Quatro a seis vezes por semana } \\
\text { Cerca de uma vez por dia } \\
\text { Duas a três vezes por dia, } \\
\text { quase todo o dia } \\
\text { Quatro ou mais vezes por dia, } \\
\text { quase todo o dia } \\
\text { Não se aplica } \\
\text { Năo sabe } \\
\text { Não respondeu }\end{array}$ & $\begin{array}{l}01 \\
02 \\
03 \\
04 \\
05 \\
05 \\
07 \\
08 \\
09 \\
00 \\
88 \\
99\end{array}$ \\
\hline
\end{tabular}




\section{DROGAS INJETÁVEIS E RISCO DE INFECCGÃO POR HIV}

\begin{tabular}{|c|c|c|c|c|}
\hline$N^{2}$ & $\begin{array}{c}\text { QUESTÕES } \\
\text { E EIXOS DE CLASSIFICAÇÃO }\end{array}$ & CATEGORIAS DE CODIFICAÇÃO & $\underset{\hat{A}}{\operatorname{DIRIGI}}$ & $\begin{array}{l}\text { GIR-SE } \\
\grave{A}\end{array}$ \\
\hline Q504 & $\begin{array}{l}\text { Com quantos parceiros sexuais "mais } \\
\text { frequentes" do sexo oposto você te- } \\
\text { ve relações sexuais vaginais/anais } \\
\text { nos últimos } 6 \text { meses? }\end{array}$ & & & \\
\hline Q505 & $\begin{array}{l}\text { Nos últimos } 6 \text { meses com que frequên } \\
\text { cia você utilizou camisinha quando } \\
\text { manteve relação sexual com seu/s } \\
\text { parceiro/s mais frequente? } \\
\text { "MOSTRE TABELA "B" }\end{array}$ & $\begin{array}{l}\text { Sempre } \\
\text { Na maioria das vezes } \\
\text { Cerca de metade das ocasiões } \\
\text { Ocasionalmente } \\
\text { Nunca } \\
\text { Não se aplica } \\
\text { Não sabe } \\
\text { Não respondeu }\end{array}$ & $\begin{array}{l}1 \\
2 \\
3 \\
4 \\
5 \\
0 \\
8 \\
9\end{array}$ & \\
\hline Q506 & $\begin{array}{l}\text { Quantos desses parceiros prin- } \\
\text { cipais do sexo oposto se utili } \\
\text { zavam de drogas injetáveis? }\end{array}$ & & & \\
\hline Q507 & $\begin{array}{l}\text { Nesses últimos } 6 \text { meses, qual método } \\
\text { de contracepção você e seu/sua par- } \\
\text { ceiro/a/os utilizaram? }\end{array}$ & 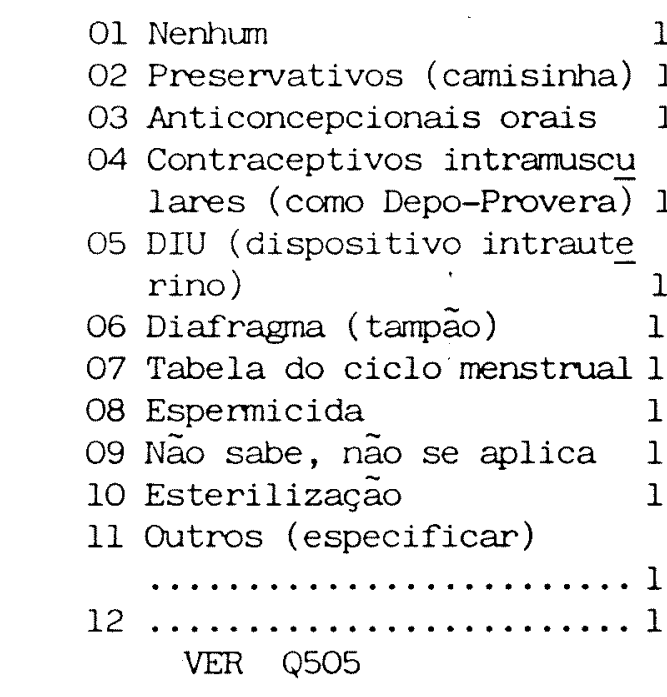 & $\begin{array}{llll}1 & 2 & 0 & 8 \\
1 & 2 & 0 & 8 \\
1 & 2 & 0 & 8 \\
1 & 2 & 0 & 8 \\
1 & 2 & & 8 \\
1 & 2 & 0 & 8 \\
1 & 2 & 0 & 8 \\
1 & 2 & 0 & 8 \\
1 & 2 & 0 & 8 \\
1 & 2 & 0 & 8 \\
1 & 2 & 0 & 8 \\
1 & 2 & 0 & 8 \\
1 & 2 & 0 & 8\end{array}$ & $\begin{array}{ll}8 & 9 \\
8 & 9 \\
8 & 9 \\
8 & 9 \\
8 & 9 \\
8 & 9 \\
8 & 9 \\
8 & 9 \\
8 & 9 \\
8 & 9 \\
8 & 9 \\
8 & 9\end{array}$ \\
\hline \multicolumn{5}{|c|}{$\begin{array}{l}\text { As questões abaixo versam sobre relação sexual com parceiros/as ocasionais do sexo oposto.Por } \\
\text { parceiro/a casual, eu quero designar alguém com quem você teve relações sexuais que não seu } \\
\text { sua parceiro/a principal. Näo se incluem aí "clientes" que pagam. }\end{array}$} \\
\hline Q508 & $\begin{array}{l}\text { Nos últimos } 6 \text { meses com que frequên } \\
\text { cia você teve relação sexual vaginal } \\
\text { com parceiros ocasionais do sexo ' } \\
\text { oposto? } \\
\text { MOSTRE A TABELA "A" }\end{array}$ & $\begin{array}{l}\text { Nunca/ nenhum } \\
\text { Menos de uma vez ao mês } \\
\text { Uma a três vezes ao mês } \\
\text { Cerca de uma vez por semana } \\
\text { Duas a três vezes por semana } \\
\text { Quatro a seis vezes por semana } \\
\text { Cerca de uma vez por dia } \\
\text { Duas a três vezes por dia, } \\
\text { quase todo o dia } \\
\text { Quatro ou mais vezes por dia, } \\
\text { quase todo o dia } \\
\text { Não se aplica } \\
\text { Não sabe } \\
\text { Não respondeu }\end{array}$ & & $\begin{array}{l}01 \\
02 \\
03 \\
04 \\
05 \\
06 \\
07 \\
08 \\
\end{array}$ \\
\hline
\end{tabular}


DROCAS INUETÁVEIS E RISCO DE INFECÇ̄̃̂ POR HIV

\begin{tabular}{|c|c|c|c|c|}
\hline No & $\begin{array}{l}\text { Questoes } \\
\text { e eixos de classilicáăo }\end{array}$ & Categorias de Codiricarão & & Dirigir-se a \\
\hline Q509 & $\begin{array}{l}\text { Nos últimos } 6 \text { meses com que frequência } \\
\text { você teve relaçá sexual anal com al- } \\
\text { gum parceiro/a sexual ocasional do se- } \\
\text { xo oposto? } \\
\text { MOSTRE A TABELA "A" } \\
\text { OBS.: Se o entrevistado responder } \\
\text { "Numca/renhum as Q508 e Q509 } \\
\text { vá para Q513 }\end{array}$ & $\begin{array}{l}\text { Nunca nenhum } \\
\text { Menos de una vez ao mês } \\
\text { Uma a três vezes ao mês } \\
\text { Cerca de uma vez por semana } \\
\text { Duas a três vezes por semana } \\
\text { Quatro a seis vezes por semana } \\
\text { Cerca de uma vez por dia } \\
\text { Duas a três vezes por dia, quase } \\
\text { todo o dia } \\
\text { Quatro ou mais vezes por dia, qua } \\
\text { se todo o dia } \\
\text { Não se aplica } \\
\text { Não sabe } \\
\text { Não respondeu }\end{array}$ & $\begin{array}{l}01 \\
02 \\
03 \\
04 \\
05 \\
06 \\
07 \\
08 \\
\\
09 \\
00 \\
88 \\
99\end{array}$ & \\
\hline Q510 & $\begin{array}{l}\text { Com quantos parceiros casuais do se- } \\
\text { xo oposto você teve relação sexual } \\
\text { vaginal ou anal nos últimos } 6 \text { meses? }\end{array}$ & & & \\
\hline Q511 & $\begin{array}{l}\text { Nos últịmos } 6 \text { meses com que frequên- } \\
\text { cia você utilizou (camisinha) ao man } \\
\text { ter relaçöes sexuais com parceiros } \\
\text { ocasionais do sexo oposto? } \\
\text { MOSTRE A TABELA "B" }\end{array}$ & $\begin{array}{l}\text { Sempre } \\
\text { Na maioria das vezes } \\
\text { Cerca de metade das ocasiörs } \\
\text { Ocasionalmente } \\
\text { Nunca } \\
\text { Não se aplica } \\
\text { Não sabe } \\
\text { Não respondeu }\end{array}$ & $\begin{array}{l}1 \\
2 \\
3 \\
4 \\
5 \\
0 \\
8 \\
9\end{array}$ & \\
\hline Q512 & $\begin{array}{l}\text { Quantos desses parceiros ocasionais } \\
\text { do sexo oposto você soube que usou } \\
\text { droga injetável? }\end{array}$ & & & \\
\hline \multicolumn{5}{|c|}{$\begin{array}{l}\text { As questoes abaixo versam sobre atividades sexuais clientes do sexo oposto, com isso eu quero me } \\
\text { referir a pessoas com quem você praticou sexo por dinheiro, bens ou drogas. Quando eu me refiro } \\
\text { a sexo aqui, isto significa relação vaginal, anal, oral ou caricias manuais. }\end{array}$} \\
\hline Q513 & $\begin{array}{l}\text { Nos últimos } 6 \text { meses com que frequên } \\
\text { cia você teve um cliente que deu } \bar{a} \\
\text { você dinheiro, bens ou drogas em } \\
\text { troca de relação sexual? } \\
\quad \text { MOSTRE A TABELA "A" }\end{array}$ & (Se a resposta for 01 ) & & Q522 \\
\hline Q514 & $\begin{array}{l}\text { Ao longo dos últimos } 6 \text { meses, quantos } \\
\text { clientes diferentes vocé teve num mês } \\
\text { que você consideraria tipico? } \\
\text { (Questione visando una estimativa } \\
\text { mais precisa) }\end{array}$ & & & \\
\hline \multicolumn{5}{|c|}{ Agora quero que voce pense acerca de todos os clientes que voce teve nos ultimos 6 meses } \\
\hline Q515 & $\begin{array}{l}\text { Nos últimos } 6 \text { meses, com que frequên } \\
\text { cia você teve relaçao sexual vaginal } \\
\text { com um cliente? } \\
\quad \text { MOSTRE A TABELA "A" }\end{array}$ & $\begin{array}{l}\text { Nunca/nenhum } \\
\text { Menos de uma vez ao mês } \\
\text { Uma a três vezes ao mês } \\
\text { Cerca de uma vez por semana } \\
\text { Duas a três vezes por semana } \\
\text { Quatro a seis vezes por semana } \\
\text { Cerca de uma vez por dia } \\
\text { Duas a três vezes por dia, qua- } \\
\text { se todo o dia } \\
\text { Quatro ou mais vezes por dia, } \\
\text { quase todo o dia } \\
\text { Não se aplica } \\
\text { lião sabe } \\
\text { Não respondeu }\end{array}$ & $\begin{array}{l}01 \\
02 \\
03 \\
04 \\
\text { O5 } \\
06 \\
07 \\
08 \\
09 \\
00 \\
88 \\
99\end{array}$ & ... Q517 \\
\hline
\end{tabular}


DROGAS INJE'IÄVEIS E RISCO DE INFECÇÃO POR HIV

\begin{tabular}{|c|c|c|c|c|}
\hline N 9 & $\begin{array}{l}\text { Questoes: } \\
\text { e eixos de classificagäo }\end{array}$ & Categorias de Codificacão & & Dirigir-sie a \\
\hline Q516 & $\begin{array}{l}\text { Com que frequência vocè usa (camisi- } \\
\text { nha) quando tem relaçäo sexual vagi- } \\
\text { nal com un cliente? }\end{array}$ & $\begin{array}{l}\text { Sempre } \\
\text { Na maioria das vezes } \\
\text { Cerca da metade das ocasiões } \\
\text { Ocasionalmente } \\
\text { Nunca } \\
\text { Não se aplica } \\
\text { Não sabe } \\
\text { Não respondeu }\end{array}$ & $\begin{array}{l}1 \\
2 \\
3 \\
4 \\
5 \\
0 \\
8 \\
9\end{array}$ & \\
\hline Q517 & $\begin{array}{l}\text { Nos últimos } 6 \text { meses com que frequên- } \\
\text { cia vocé teve sexo oral com un clien } \\
\text { te? } \\
\quad \text { MOSTRE A 'IABELA "A" }\end{array}$ & $\begin{array}{l}\text { Nunca/nenhum } \\
\text { Menos de una vez ao mês } \\
\text { Uma a três vezes ao mês } \\
\text { Cerca de uma vez por semana } \\
\text { Duas a três vezes por semana } \\
\text { Quatro a seis vezes por sema- } \\
\text { na } \\
\text { Cerca de uma vez por dia } \\
\text { Duas a três vezes por dia, } \\
\text { quase todo o dia } \\
\text { Quatro ou mais vezes por } \\
\text { dia, quase todo o dia } \\
\text { Não se aplica } \\
\text { Não sabe } \\
\text { Não respondeu }\end{array}$ & $\begin{array}{l}01 \\
02 \\
03 \\
04 \\
05 \\
06 \\
07 \\
08 \\
09 \\
00 \\
88 \\
99\end{array}$ & . . Q519 \\
\hline Q518 & $\begin{array}{l}\text { Com que frequência você usou (camisi- } \\
\text { nha) ao praticar sexo oral com um } \\
\text { cliente? } \\
\text { MOSTRE A TABELA "B" }\end{array}$ & $\begin{array}{l}\text { Sempre } \\
\text { Na maioria das vezes } \\
\text { Cerca de metade das ocasiōes } \\
\text { Ocasionalmente } \\
\text { Nunca } \\
\text { Não se aplica } \\
\text { Não sabe } \\
\text { Não respondeu }\end{array}$ & $\begin{array}{l}1 \\
2 \\
3 \\
4 \\
5 \\
0 \\
8 \\
9\end{array}$ & \\
\hline Q519 & $\begin{array}{l}\text { Nos últimos } 6 \text { meses con que frequên- } \\
\text { cia você teve relaçoes sexuais anais } \\
\text { com um cliente? } \\
\text { MOSTRE A TABELA "A" }\end{array}$ & $\begin{array}{l}\text { Nunca/nenhum } \\
\text { Menos de uma vez ao mêss } \\
\text { Uma a três vezes ao mês } \\
\text { Cerca de uma vez por semana } \\
\text { Duas a três vezes por semana } \\
\text { Quatro a seis vezes por sema } \\
\text { na } \\
\text { Cerca de unna vez por dia } \\
\text { Duras a três vezes por dia, } \\
\text { quase todo o dia } \\
\text { Quatro ou mais vezes por } \\
\text { dia quase todo o dia } \\
\text { Não se aplica } \\
\text { Não sabe } \\
\text { Não respondeu }\end{array}$ & $\begin{array}{l}01 \\
02 \\
03 \\
04 \\
05 \\
06 \\
07 \\
08 \\
09 \\
00 \\
88 \\
99\end{array}$ & $\ldots . \mathrm{Q} 521$ \\
\hline
\end{tabular}


DROGAS INJETÁVEIS E RISCO DE INFECCÃ̃O POR HIV

\begin{tabular}{|c|c|c|c|}
\hline$N^{0}$ & $\begin{array}{l}\text { QUESTÕES } \\
\text { E EIXOS DE CLASSIFICAÇÃO }\end{array}$ & CATEGORIAS DE CODIFICAÇÃO & $\begin{array}{l}\text { DIRIGIR-SE } \\
\dot{A}\end{array}$ \\
\hline Q520 & $\begin{array}{l}\text { Com que frequência você usou } \\
\text { camisinha ao manter relaçöes } \\
\text { sexuais anais com um cliente? } \\
\text { MOSTRE A TABELA "B" }\end{array}$ & $\begin{array}{l}\text { Sempre } \\
\text { Na maioria das vezes } \\
\text { Cerca de metade das ocasiões } \\
\text { Ocasionalmente } \\
\text { Nunca } \\
\text { Não se aplica } \\
\text { Não sabe } \\
\text { Não respondeu }\end{array}$ & \\
\hline Q521 & $\begin{array}{l}\text { Nos ultimos } 6 \text { meses com que' } \\
\text { frequênciá você manipulou os } \\
\text { genitais de um cliente? } \\
\text { MOSTRE A TABELA "A" }\end{array}$ & $\begin{array}{l}\text { Nunca/ nerhum } \\
\text { Menos de uma vez ao mês } \\
\text { Uma a três vezes ao mês } \\
\text { Cerca de uma vez por semana } \\
\text { Duas a três vezes por semana } \\
\text { Quatro a seis vezes p/semana } \\
\text { Cerca de uma vez por dia } \\
\text { Duas a três vezes por dia, } \\
\text { quase todo dia } \\
\text { Quatro ou mais vezes por dia, } \\
\text { quase todo dia } \\
\text { Não se aplica } \\
\text { Não sabe } \\
\text { Não respondeu }\end{array}$ & \\
\hline \multicolumn{4}{|c|}{ SOMENTE PARA HOMENS; SE A ENTREVISTADA FOR MULHER } \\
\hline Q522 & $\begin{array}{l}\text { Com que frequência você teve rela } \\
\text { cão sexual (anal/oral) com outro } \\
\text { homem, incluindo travesti, nos úl- } \\
\text { timos } 5 \text { anos (incluindo período ' } \\
\text { passado na prisão ou relação sob } \\
\text { coaça) } \\
\text { MosTRE A TABEIA "A" }\end{array}$ & ( $\mathrm{Se}$ a resposta for $\mathrm{Ol}$ ) & . ...Q601 \\
\hline \multicolumn{4}{|c|}{$\begin{array}{l}\text { A próxima questão é sobre relação sexual anal com um parceiro principal do mesmo sexo. Lem- } \\
\text { bre-se que parceiro principal significa alguém que è seu parceiro sexual mais importante. }\end{array}$} \\
\hline Q523 & $\begin{array}{l}\text { Nos últimos } 6 \text { meses com que fre- } \\
\text { quência vocé teve relação sexual } \\
\text { anal com um parceiro principal ' } \\
\text { do mesmo sexo? } \\
\text { MOSTRE A TAEELA "A" }\end{array}$ & $\begin{array}{l}\text { Nunca/ nenhum } \\
\text { Menos de uma vez ao mês } \\
\text { Uma a três vezes ao mês } \\
\text { Cerca de uma vez por semana } \\
\text { Duas a três vezes por semana } \\
\text { Quatro a seis vezes p/semana } \\
\text { Cerca de uma vez por dia } \\
\text { Duas a três vezes por dia, } \\
\text { quase todo o dia } \\
\text { Quatro ou mais vezes por dia, } \\
\text { quase todo o dia } \\
\text { Não se aplica } \\
\text { Não sabe } \\
\text { Não respondeu }\end{array}$ & . Q527 \\
\hline
\end{tabular}


DROGAS INUETÁVEIS E RISCO DE INFEOCÃ̃O POR HIV

\begin{tabular}{|c|c|c|c|}
\hline No & $\begin{array}{l}\text { QUESTÕES } \\
\text { E EIXOS DE CLASSIFICAÇÃO }\end{array}$ & CATEGORIAS DE CODIFICAÇÃO & $\underset{\dot{A}}{D I R I G I R-S E}$ \\
\hline Q524 & $\begin{array}{l}\text { Com quantos parceiros principais do } \\
\text { mesmo sexo você teve relaçöes } \\
\text { sexuais anais nos últimos } 6 \text { meses? }\end{array}$ & & \\
\hline Q525 & $\begin{array}{l}\text { Nos últimos } 6 \text { meses com que frequên } \\
\text { cia você utilizou camisinha ao man- } \\
\text { ter relaçôes sexuais anais com par- } \\
\text { ceiro principal do mesmo sexo? } \\
\text { MOSTRE A TABELA "A" }\end{array}$ & $\begin{array}{l}\text { Sempre } \\
\text { Na maioria das vezes } \\
\text { Cerca de metade das ocasiöes } \\
\text { Ocasionalmente } \\
\text { Nunca } \\
\text { Não se aplica } \\
\text { Não sabe } \\
\text { Não respondeu }\end{array}$ & \\
\hline Q526 & $\begin{array}{l}\text { Quantos desses parceiros sexuais ' } \\
\text { principais do mesmo sexo você sou- } \\
\text { be que usavam drogas em algum mo-' } \\
\text { mento? }\end{array}$ & & \\
\hline \multicolumn{4}{|c|}{$\begin{array}{l}\text { A questão subsequente é sobre relação sexual anal com parceiros OCASIONAIS do MESMO SEXO. } \\
\text { Por parceiro casual entenda-se alguém que não o seu parceiro principal/mais importante ou } \\
\text { cliente. }\end{array}$} \\
\hline Q527 & $\begin{array}{l}\text { Nos últimos } 6 \text { meses com que fre- } \\
\text { quência você manteve relações } \\
\text { sexuais anais com parceiros oca- } \\
\text { sionais do seu sexo? }\end{array}$ & $\begin{array}{l}\text { Nunca/nenhum } \\
\text { Menos de una vez ao mês } \\
\text { Uma a três vezes ao mês } \\
\text { Cerca de uma vez por semana } \\
\text { Duas a três vezes por semana O } \\
\text { Quatro a seis vezes p/semana O } \\
\text { Cerca de uma vez por dia } \\
\text { Duas a três vezes por dia, } \\
\text { quase todo o dia } \\
\text { Quatro ou mais vezes por dia, } \\
\text { quase todo o dia } \\
\text { Não se aplica } \\
\text { Não sabe } \\
\text { Não respondeu }\end{array}$ & $\ldots . Q 531$ \\
\hline Q528 & $\begin{array}{l}\text { Com quantos parceiros ocasionais } \\
\text { do mesmo sexo você manteve rela- } \\
\text { ções sexuais anais nos últimos } \\
6 \text { meses? }\end{array}$ & & \\
\hline Q529 & $\begin{array}{l}\text { Nos últimos } 6 \text { meses com que frequên } \\
\text { cia você utilizou camisinha ao ter " } \\
\text { relaçōes sexuais anais com parceiro/s } \\
\text { do mesmo sexo? } \\
\text { MOSTRE A TABELA "B" }\end{array}$ & $\begin{array}{l}\text { Sempre } \\
\text { Na maioria das vezes } \\
\text { Cerca de metade das ocasiões } \\
\text { Ocasionalmente } \\
\text { Nunca } \\
\text { Não se aplica } \\
\text { Não sabe } \\
\text { Não respondeu }\end{array}$ & $\begin{array}{l}4 \\
5 \\
0\end{array}$ \\
\hline Q530 & $\begin{array}{l}\text { Quantos desses parceiros casuais vo } \\
\text { cê soube que usavam drogas em algum } \\
\text { momento? }\end{array}$ & & \\
\hline
\end{tabular}


DROCAS INUETÁVEIS E RISCO DE INFEOCÃ̃O POR HIV

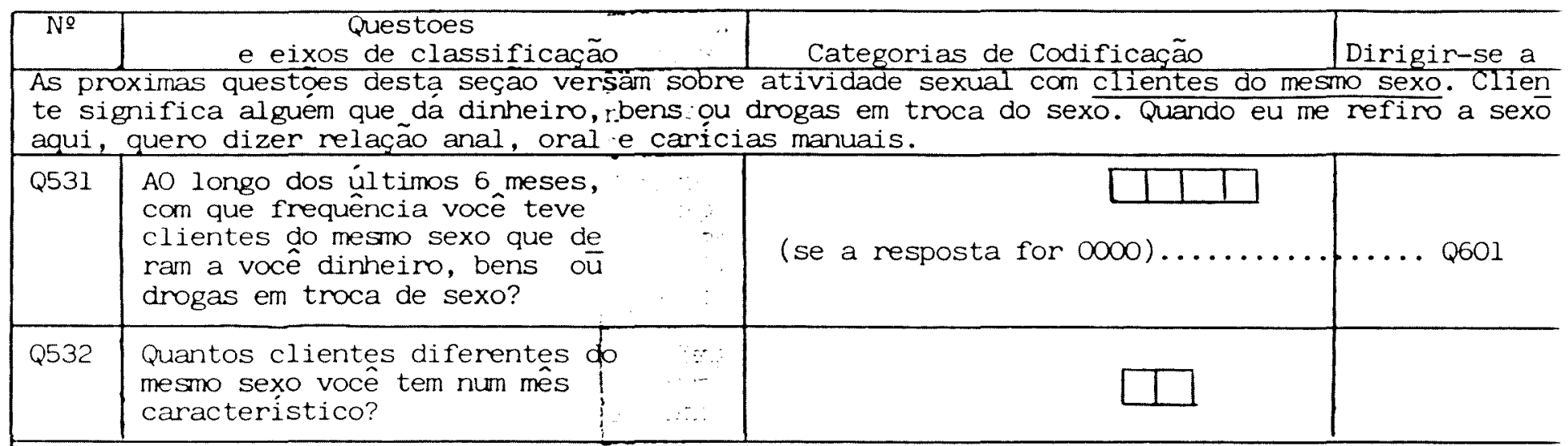

Eu goștaria de pedir a voố para lembrar de. todos os seus clientes do mesmo sexo que você teve nos ultimos 6 meses.

\begin{tabular}{|c|c|c|c|c|}
\hline Q533 & $\begin{array}{l}\text { Nos últimos } 06 \text { meses com que } \\
\text { frequência você praticou se- } \\
\text { xo oral com seus clientes? } \\
\text { MOSTRE A TABELA "A" }\end{array}$ & $\begin{array}{l}\text { Nunca/Nenhum } \\
\text { Menos dê uma vez ao mês } \\
\text { Uma atrés vezes ao mês } \\
\text { Cerca de una vez por semana } \\
\text { Duas a três vezes por semana } \\
\text { Quatro a seis vezes por semana } \\
\text { Cerca de uma vez por dia } \\
\text { Duas a três vezes por dia, quase } \\
\text { todo o dia } \\
\text { Quatro ou mais vezes por dia, } \\
\text { quase todo o dia } \\
\text { Não se aplica } \\
\text { Não sabe } \\
\text { Não respondeu }\end{array}$ & $\begin{array}{l}\text { O1 } \\
\text { O2 } \\
\text { O3 } \\
04 \\
05 \\
06 \\
07 \\
08 \\
09 \\
00 \\
88 \\
99\end{array}$ & .... Q535 \\
\hline Q534 & $\begin{array}{l}\text { Com que frequência você usou } \\
\text { (camisinha) ao praticar sexo } \\
\text { oral com seus clientes? } \\
\text { MOSTRE A TABELA "B" }\end{array}$ & $\begin{array}{l}\text { Sermpre } \\
\text { Na maioria das vezes } \\
\text { Cerca da metade das ocasiões } \\
\text { Ocasionalmente } \\
\text { Nunca } \\
\text { Não se aplica } \\
\text { Não sabe } \\
\text { Não respondeu }\end{array}$ & $\begin{array}{l}1 \\
2 \\
3 \\
4 \\
5 \\
0 \\
8 \\
9\end{array}$ & \\
\hline Q535 & $\begin{array}{l}\text { Nos últimos } 06 \text { meses com que } \\
\text { frequência você teve relação se- } \\
\text { xual anal com seus clientes? }\end{array}$ & $\begin{array}{l}\text { Nunca/Nenhum } \\
\text { Menos de uma vez ao mês } \\
\text { Uma a três vezes ao mês } \\
\text { Cerca de uma vez por semana } \\
\text { Duas a três vezes por semana } \\
\text { Quatro a seis vezes por semana } \\
\text { Cerca de una vez por dia } \\
\text { Duas a três vezes por dia, quase } \\
\text { todo o dia } \\
\text { Quatro ou mais vezes por dia, } \\
\text { quase todo o dia } \\
\text { Não se aplica } \\
\text { Não sabe } \\
\text { Não respondeu }\end{array}$ & $\begin{array}{l}01 \\
02 \\
03 \\
04 \\
05 \\
06 \\
07 \\
08 \\
09 \\
00 \\
88 \\
99\end{array}$ & .... Q537 \\
\hline
\end{tabular}


DROGAS INUETÁVEIS E RLSCO DE INFFOCÃ̃O POR HIV

\begin{tabular}{|c|c|c|c|}
\hline Ne & $\begin{array}{l}\text { Questoes } \\
\text { e eixos de classificação }\end{array}$ & Categoria de Codificação & \\
\hline Q536 & $\begin{array}{l}\text { Com que frequência você usou cami- } \\
\text { sinha ao manter relações sexuais " } \\
\text { anais com seus clientes? } \\
\text { MOSTRE A TABELA "B" }\end{array}$ & $\begin{array}{l}\text { Sempre } \\
\text { Na maioria das vezes } \\
\text { Cerca da metade das ocasiöes } \\
\text { Ocasionalmente } \\
\text { Nunca } \\
\text { Não se aplica } \\
\text { Não sabe } \\
\text { Não respondeu }\end{array}$ & $\begin{array}{l}1 \\
2 \\
3 \\
4 \\
5 \\
0 \\
8 \\
9\end{array}$ \\
\hline Q537 & $\begin{array}{l}\text { Nesses últimos } 06 \text { meses, com que } \\
\text { frequência voce fez caricias ma- } \\
\text { nauais nos seus clientes? } \\
\text { MOSTRE A TABELA "A" }\end{array}$ & $\begin{array}{l}\text { Nunca/Nenhum } \\
\text { Menos de uma vez ao mês } \\
\text { Uma a trés vezes ao mês } \\
\text { Cerca de uma vez por semana } \\
\text { Duas a três vezes por semana } \\
\text { Quatro a seis vezes por semana } \\
\text { Cerca de uma vez por dia } \\
\text { Duas a três vezes por dia, } \\
\text { quase todo o dia } \\
\text { Quatro ou mais vezes por dia, } \\
\text { quase todo o dia } \\
\text { Não se aplica } \\
\text { Não sabe } \\
\text { Não respondeu }\end{array}$ & $\begin{array}{l}01 \\
02 \\
03 \\
04 \\
05 \\
06 \\
07 \\
08 \\
09 \\
09 \\
00 \\
88 \\
99\end{array}$ \\
\hline
\end{tabular}




\section{DROGAS INJETÁVEIS E RISCO DE INFECÇÃO POR HIV}

\section{SEÇÃO 6: CONHECIMENTO ACERCA DA AIDS E MODIFICAÇÕES DE COMPORTAMENTO}

Eu gostaria agora de perguntar a você algumas questões acerca da AIDS e sobre alguns aspectos do seu comportamento relativo ao consumo de drogas injetáveis e hábitos sexuais.

\begin{tabular}{|c|c|c|c|c|c|}
\hline № & $\begin{array}{c}\text { Questoes } \\
\text { e eixos de classificação }\end{array}$ & \multicolumn{4}{|l|}{ Categorias de Codificação } \\
\hline Q601 & $\begin{array}{l}\text { Com que frequência você conversa so } \\
\text { bre AIDS com seus amigos usuarios } \\
\text { de drogas? }\end{array}$ & $\begin{array}{l}\text { Frequentemente } \\
\text { Raramente } \\
\text { Nunca }\end{array}$ & 3 & \multicolumn{2}{|l|}{$\frac{1}{3}$} \\
\hline Q602 & $\begin{array}{l}\text { Com que frequência você conversa so } \\
\text { bre AIDS com seu(s) parceiro(s) se- } \\
\text { xual(is)? }\end{array}$ & $\begin{array}{l}\text { Frequentemente } \\
\text { Raramente } \\
\text { Nunca }\end{array}$ & & \multicolumn{2}{|l|}{$\begin{array}{l}1 \\
2 \\
3\end{array}$} \\
\hline Q603 & $\begin{array}{l}\text { Com que frequência você conversa so } \\
\text { bre AIDS com membros da sua familiâ? }\end{array}$ & $\begin{array}{l}\text { Frequentemente } \\
\text { Raramente } \\
\text { Nunca }\end{array}$ & & \multicolumn{2}{|c|}{$\begin{array}{l}1 \\
2 \\
3\end{array}$} \\
\hline Q604 & $\begin{array}{l}\text { Você acredita que alguém possa ser } \\
\text { portador do vírus da AIDS e ter um } \\
\text { aspecto saudável? }\end{array}$ & $\begin{array}{l}\operatorname{Sim} \\
N \tilde{a} O \\
\text { Não sabe }\end{array}$ & & \multicolumn{2}{|c|}{$\begin{array}{l}1 \\
2 \\
3\end{array}$} \\
\hline Q605 & $\begin{array}{l}\text { Você poderia me dizer todos os modos } \\
\text { pelos quais uma pessoa pode ser in- } \\
\text { fectada com o virus da AIDS? }\end{array}$ & \multicolumn{4}{|l|}{$\begin{array}{l}\text { O1 Não conhece nenhum } \\
\text { meio de contrair a } \\
\text { AIDS }\end{array}$} \\
\hline & $\begin{array}{l}\text { USO DE DROGAS } \\
\text { (Não sugira nada ao entrevistado. Ape } \\
\text { nas pergunte utilizando "algo mais?") }\end{array}$ & 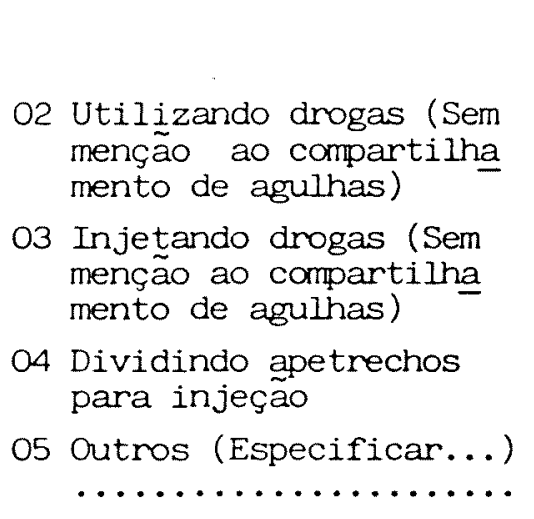 & $\begin{array}{l}\text { SIN } \\
1 \\
1 \\
1 \\
1 \\
1\end{array}$ & $\begin{array}{l}\mathrm{M} N \overline{\mathrm{A}} \\
2 \\
2 \\
2 \\
2 \\
2\end{array}$ & $\begin{array}{l}9 \\
9 \\
9\end{array}$ \\
\hline & CONTATO SEXUAL & $\begin{array}{l}06 \text { Atividade Sexual } \\
\text { (Não especificada) } \\
07 \text { Atividade Sexual } \\
\text { (Homossexual) } \\
\text { O8 Atividade Sexual } \\
\text { (Heterossexual) } \\
\text { O9 Relação sexual } \\
\text { (Não especificado) } \\
\text { 10 Coito Anal }\end{array}$ & $\begin{array}{l}1 \\
1\end{array}$ & $\begin{array}{l}2 \\
2\end{array}$ & $\begin{array}{l}9 \\
9 \\
9 \\
9 \\
9\end{array}$ \\
\hline
\end{tabular}


DROGAS INUETÁVEIS E RISCO DE INFEOCÃ̃O POR HIV

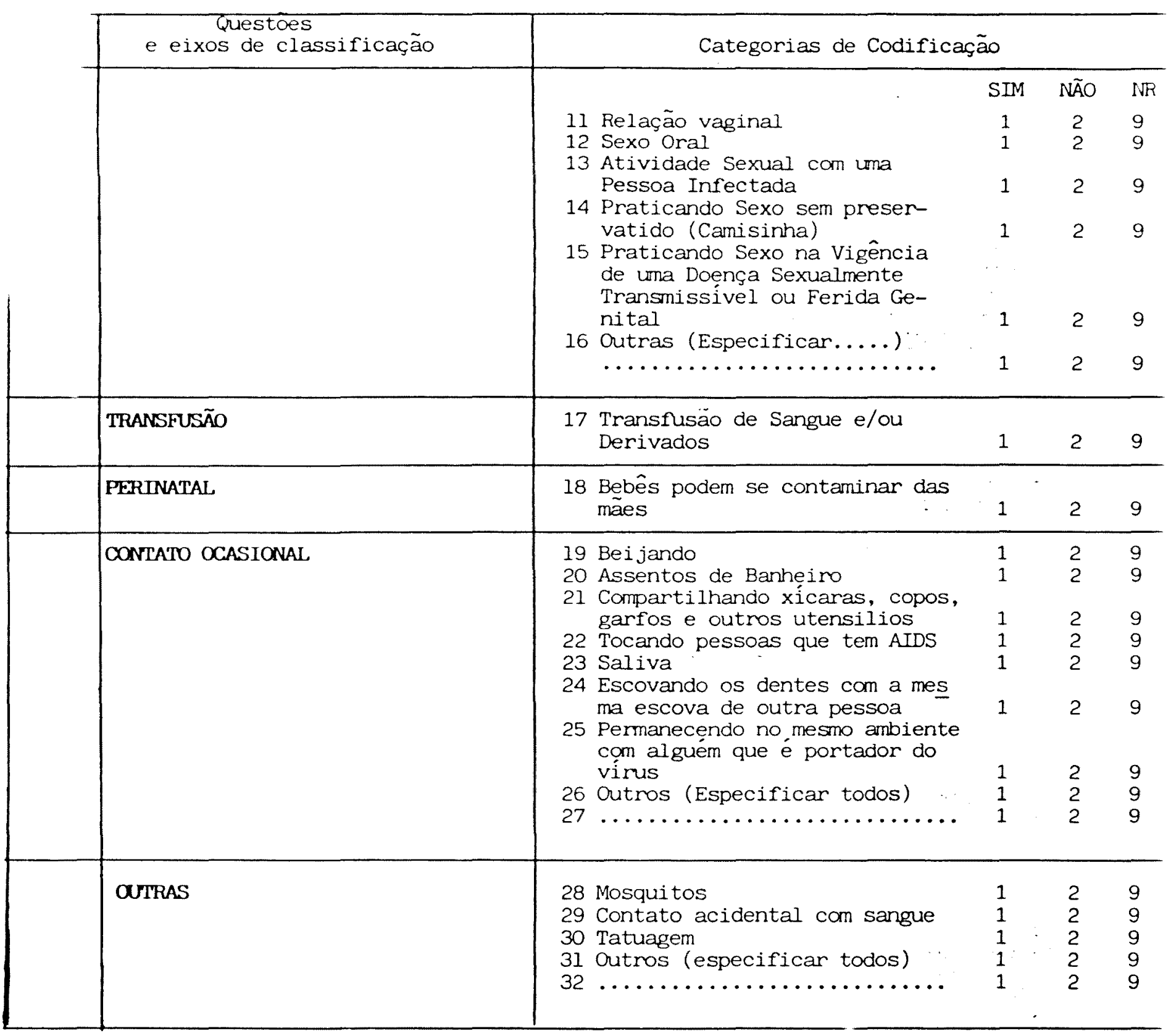


DROGAS INUETÁVEIS E RISCO DE INFEOCÃO POR HIV

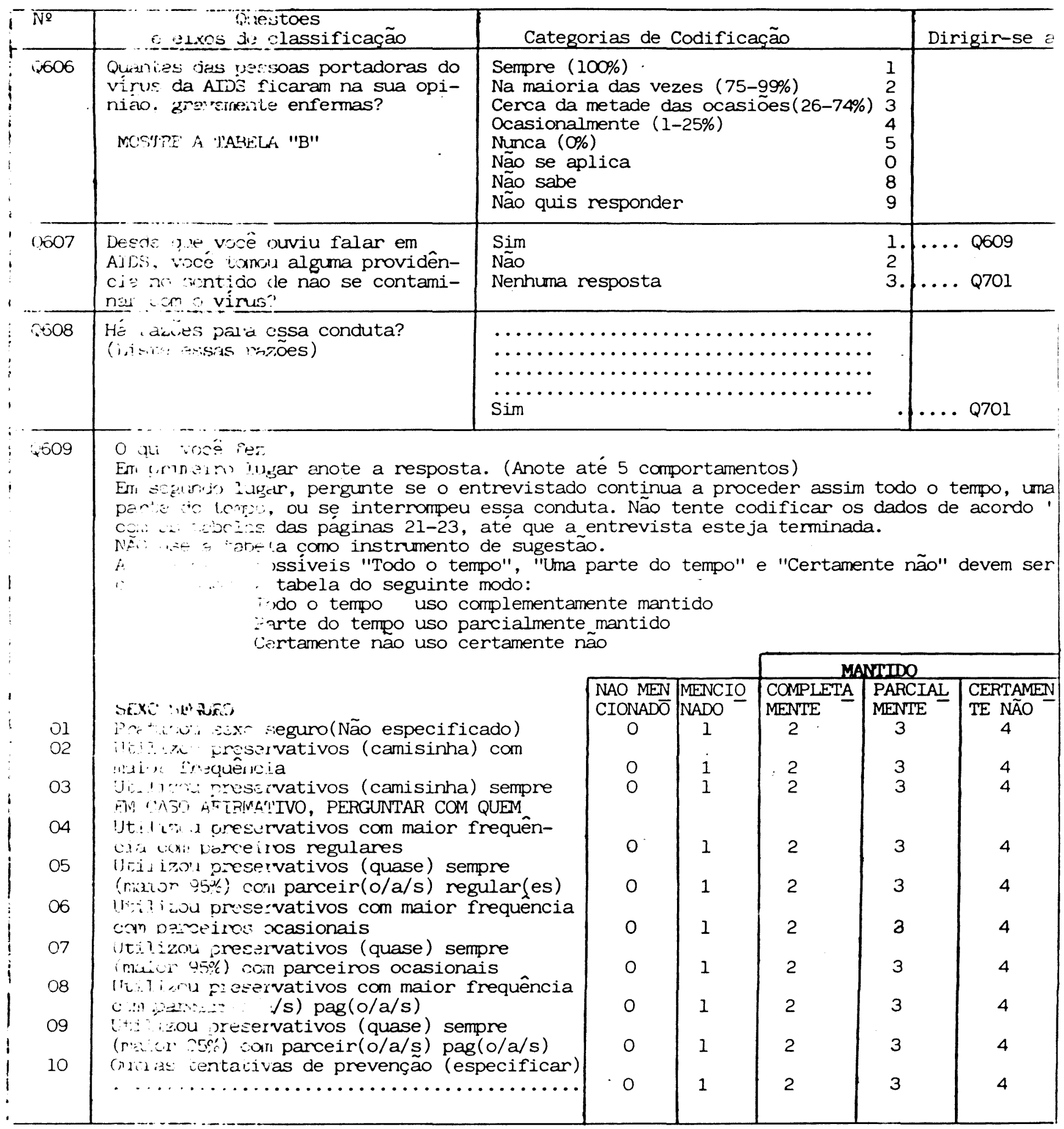


DROGAS INJETÁVEIS E RISCO DE INFECÇÃO POR HIV

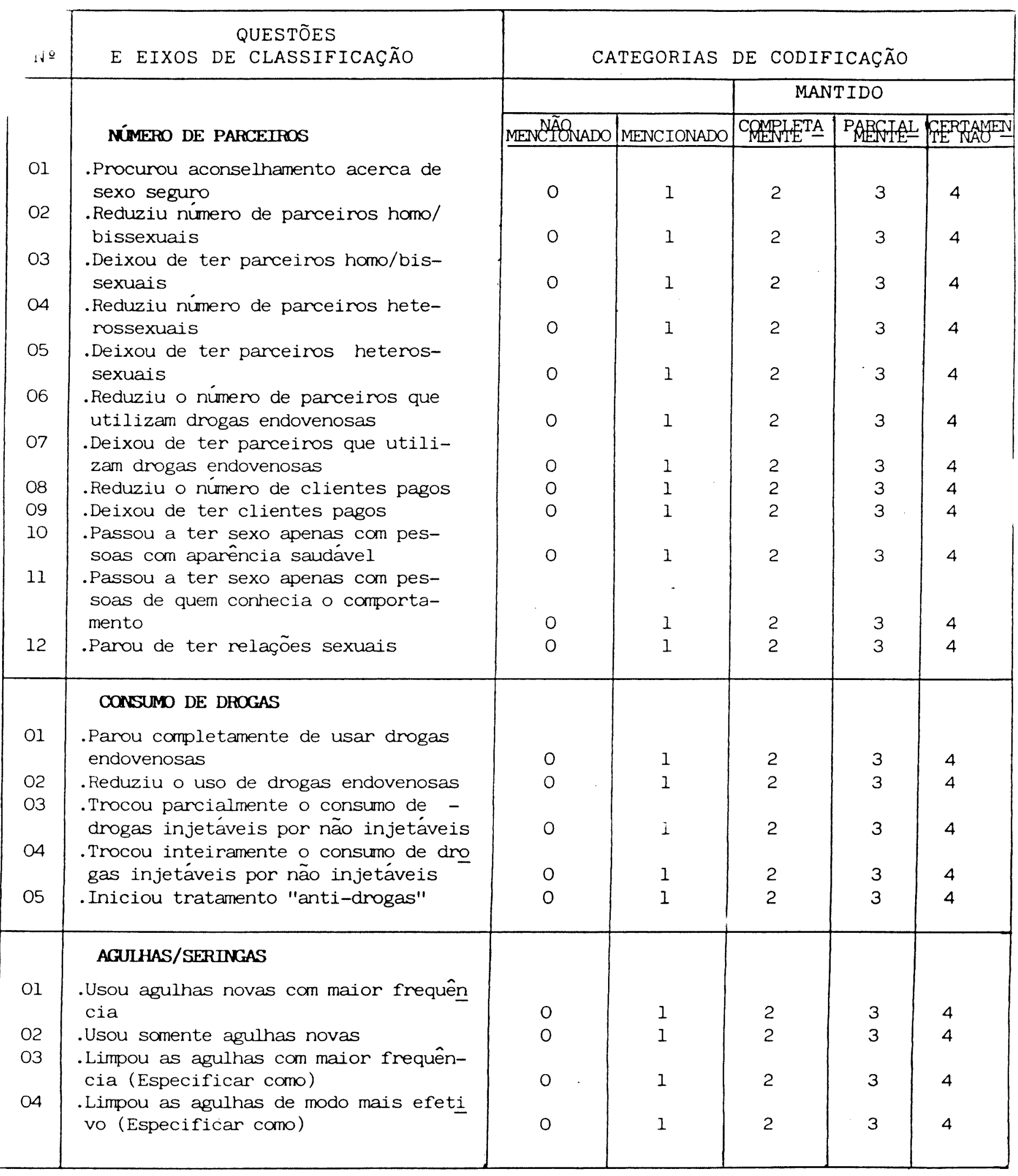




\section{DROGAS INJETÁVEIS E RISCO DE INFECÇÃO POR HIV}

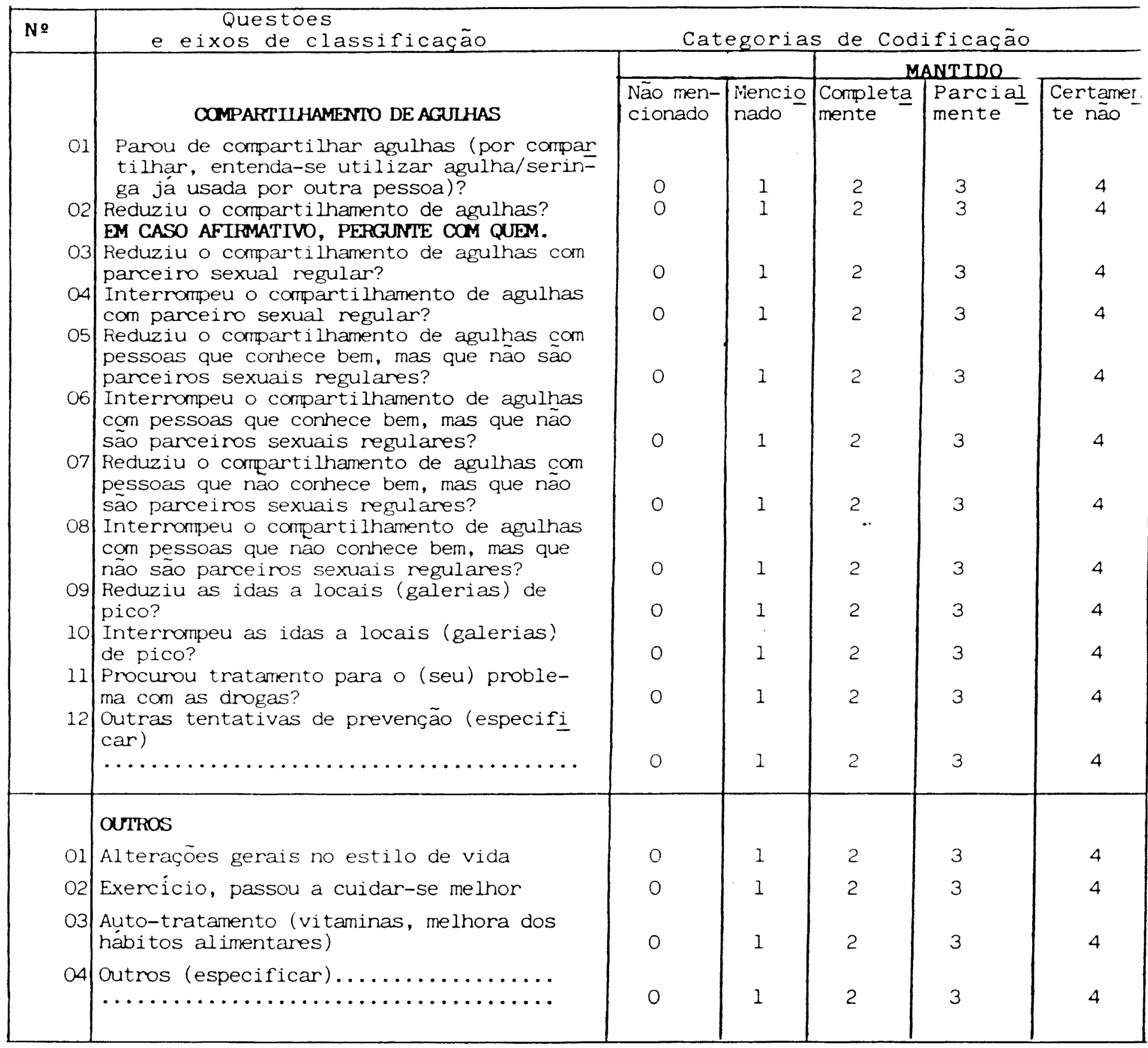




\section{DROGAS INUETÁVEIS E INFEOCÃO POR HTV}

\section{SEÇÃO 7: HISTÓRLA DE VIAGENSS}

erminar, eu gostaria de perguntar a você algumas questões acerca de diferentes locais ade você viajou nos últimos 2 anos e eventualmente injetou drogas.

\begin{tabular}{|c|c|c|c|}
\hline & $\begin{array}{l}\text { Questoes } \\
\text { e eixos de classificação }\end{array}$ & Categorias de Codificação & $\begin{array}{c}\text { Dirigir-se } \\
\text { a }\end{array}$ \\
\hline & $\begin{array}{l}\text { Você injetou drogas fora do perimetro } \\
\text { desta cidade nos ulltimos } 02 \text { anos? }\end{array}$ & $\begin{array}{l}\text { Sim } \\
\text { Não }\end{array}$ & $\ldots$ Q801 \\
\hline 2 & $\begin{array}{l}\text { Poderia me dizer o nome de todos os } \\
\text { diferentes locais onde voce se inje- } \\
\text { tou dropisis? } \\
\text { Se forem mais de } 5 \text {, diga-me o nome } \\
\text { dos } 5 \text { locais em que isso se deu com } \\
\text { maior frequência. }\end{array}$ & \multicolumn{2}{|l|}{$\begin{array}{l}\text { Local } 1 \ldots \\
\text { Local } 2 \ldots \\
\text { Local } 3 \ldots \\
\text { Local } 4 \ldots \\
\text { Local } 5 \ldots\end{array}$} \\
\hline Q703 & $\begin{array}{l}\text { Você compartilhou agulhas e seringas } \\
\text { em alguns desses lugares? Nos estamos } \\
\text { interessados apenas nas pessoas que } \\
\text { você encontrou nesses lugares. }\end{array}$ & $\begin{array}{l}\text { Sim } \\
\text { Não } \\
\text { Nenhuma Resposta }\end{array}$ & . Q Q801 \\
\hline Q704 & $\begin{array}{l}\text { Poderia me dizer os lugares em que } \\
\text { isso ocorreu? Se forem mais de } 5 \text {, } \\
\text { diga-me os } 5 \text { lugares onde isso ocor } \\
\text { reu com maior frequencia. }\end{array}$ & \multicolumn{2}{|l|}{ 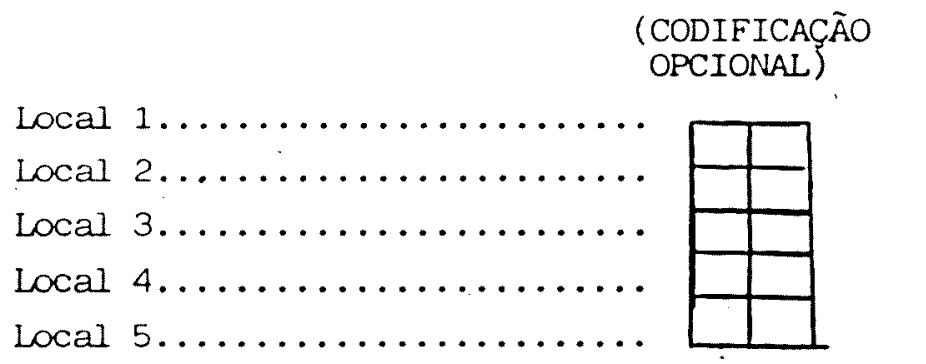 } \\
\hline
\end{tabular}


DROGAS INJETÁVEIS E IRISCO DE INFECÇÃO POH HIV

SEÇÃo 8 : TESTAGEM PARA HIV

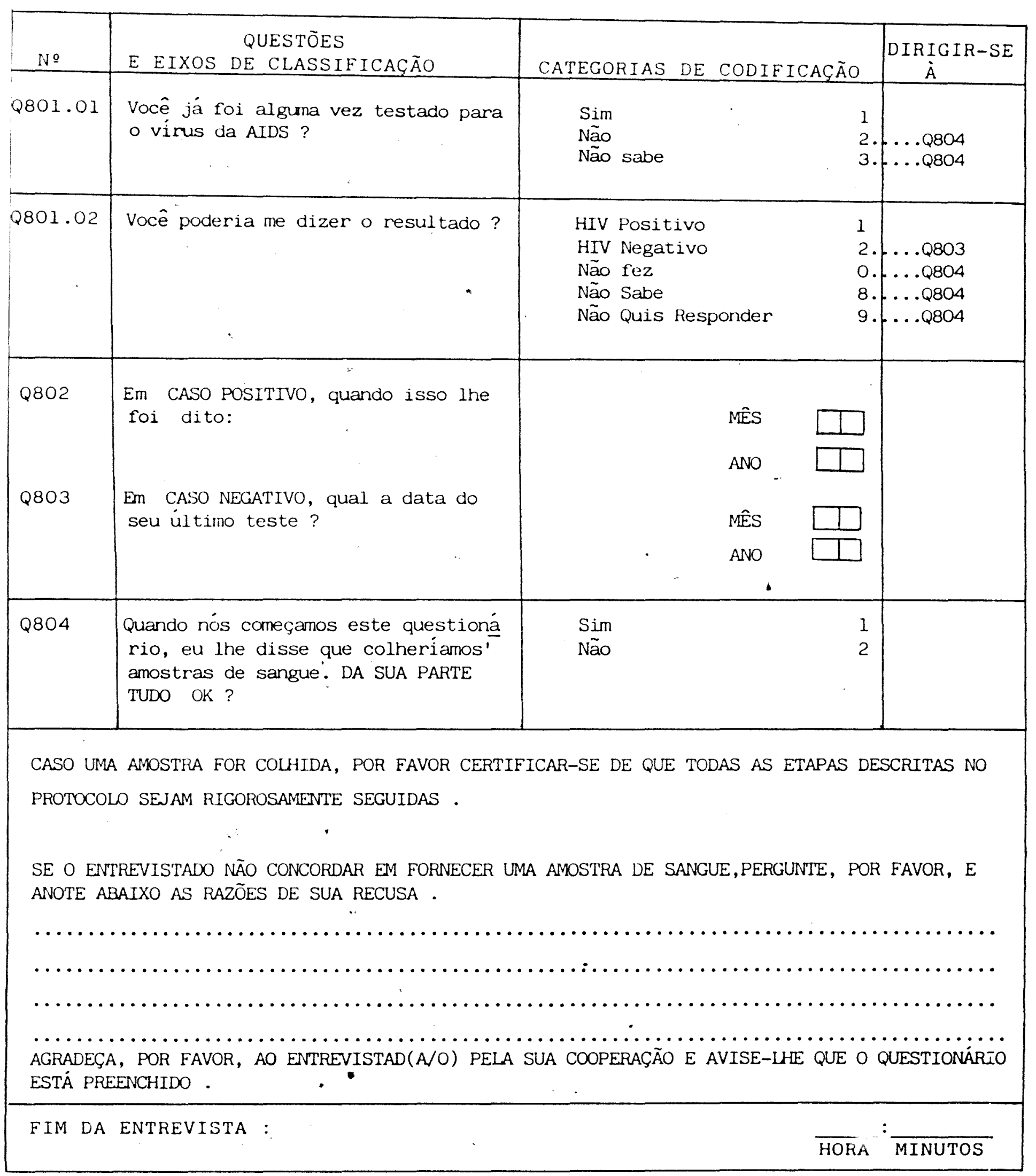


VIII.2 - Questionário do Estudo II, com consentimento informado. 


\section{Projeto Brasil - HIV/Drogas Injetáveis}

Estudo de Soroprevalência e Comportamento entre Usuários de Drogas Injetáveis nas cidades de Santos (SP), Rio de Janeiro (RJ), Itajai (SC), Salvador (Ba) e Campo Grande (MS).

\section{Consentimento para participar de pesquisa}

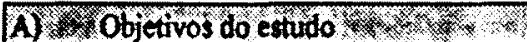

O projeto Brasil tem como objetivo estudar comportamentos de risco para o contágio pelo HIV e outras doencas infecciosas entre usuários de drogas injetáveis

A coordenação nacional deste projeto está a cargo da Dra. Regina Bueno do IEPAS (Instituto de Estudos e Pesquisas em AIDS de Santos)

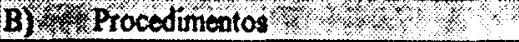

Se eu concordar em participar deste estudo deverei:

1 - Responder a um questionário acerca de dados pessoais, comportamentos de risco para o contágio pelo HIV e outros problemas de saúde

2 - Serăo colhidos de 10 a $20 \mathrm{ml}$ de meu sangue para realizaçăo de testes para o HIV e outras doenças infecciosas.

3 - Eu receberei confidencialmente os resultados de todos os exames, se assim o desejar

4 - Eu receberei a quantia equivalente a CRS $6.000,00$ (cerca de U\$ 3,00 em junho de 1994) a titulo de compensação do tempo dispendido no estudo e gasto com transporte

5- A entrevista durará cerca de $\mathbf{4 0}$ minutos.

\section{C) X Riscos e Desconfortos}

Todos os exames serão realizados com material descartável Os riscos referentes ao exame são mínimos, iguais aos de qualquer exame laboratorial de sangue

Confidencialidade

Eu receberei, se assim o quiser, pessoalmente, os resultados de meus exames. Estes resultados não serão revelados a terceiros, a menos que eu assim o desejar mediante uma autorização por escrito.

Meus dados pessoais serão arquivados em locais seguros a que só terão acesso os responsáveis pelo projeto. Minha identidade pessoal não serã mencionada em qualquer hipótese. Os dados publicados serão referentes ao conj nto de pessoas participantes do estudo, de forma a não permitir a identificação individual de qualquer um dos participantes. 


\section{D) 7 Dúvidas $\times$}

Em caso de dúvidas ou comentários adicionais acerca deste projeto poderei me comunicar com a Dra. Regina Bueno, coordenadora geral do Projeto Brasil, no IEPAS, Av. Almirante Cochrane 130, Santos (SP), Tel. (0132) 387259 ou (0132) 36 5828, além das coordenaçðes regionais listadas em anexo.

\section{E) Consentimento}

A participaçăo neste estudo é absolutamente voluntária. Eu poderei abandonar este estudo, a qualquer momento, sem qualquer prejuizo pessoal.

Contarei com o apoio das coordenaçðes regionais, independentemente de minha participação ou não na pesquisa, no sentido de obter orientaçăo quanto a aconselhamento e eventual tratamento médico no caso de resultado positivo em quaisquer dos exames laboratoriais realizados e/ou em atenção a solicitações individuais.

Eu li este formulário e recebi as explicaçðes necessárias da/do

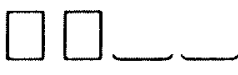

entrevistador

\section{data (local/dia/mês/ano)}

Assinatura do entrevistado

Assinatura do entrevistador

\section{Identificação}

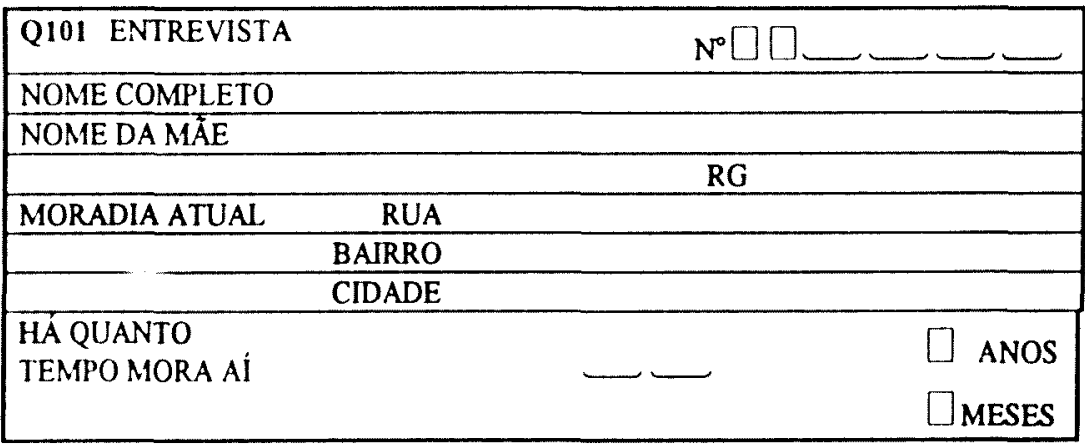

\section{SEÇÃO 1. INFORMAÇÕES SOBRE A ENTREVISTA}

Indcio

\begin{tabular}{|lll|}
\hline Q101 ENTREVISTA & Q102 & Número de código do entrevistador \\
\hline Q103 & DATA DA ENTREVISTA dia mês ano & \\
\hline Q104 De onde está sendo recrutado o entrevistado? & código $\square \square$ \\
\hline
\end{tabular}

\section{Dados pessoais}

Q105 Qual a data de nascimento (dia mès ano)

$\begin{array}{lll}\text { Q106 SEXO } & 1 & 1 \\ & \text { homem } & \text { (1) } \square \\ \text { mulher } & \text { (2) }\end{array}$

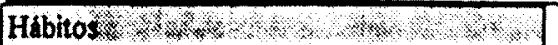

Q107 Quando você se injetou drogas pela última vez? últimos 2 meses $1 \mathrm{D}$

Q108 Você já fez algum tipo de tratamento com

últimos 6 meses $(2 \square$

relação ao uso de drogas?

Q109 De que tipos de tratamento ou auxilio você se utilizou?

01 Aconselhamento no sentido de interromper 0

consumo de drogas (pacientes ambulatoriais)

$\sin (1) \square$

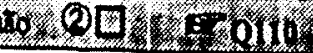

Grupos de auxilio mútuo

กล๊०ญ口

03 Terapeuta tradicional

04 Desintoxicação

$\operatorname{sim}(1) \quad$ กส̃oอ $\square$

$\operatorname{sim}(1)$ não $2 \square$

Reabilitação domiciliar

06 Internação

07 Grupo de apoio religioso

$\sin (1) \square$

$\operatorname{sim}(1) \square \quad$ กล๊o $\square$

08 Outros (especificar)

$\operatorname{sim}(1) \quad$ กð๐2 $\square$

Prisoes:

Q110 Quantas vezes você esteve detido ou preso desde a primeira vez que você se injetou drogas? 


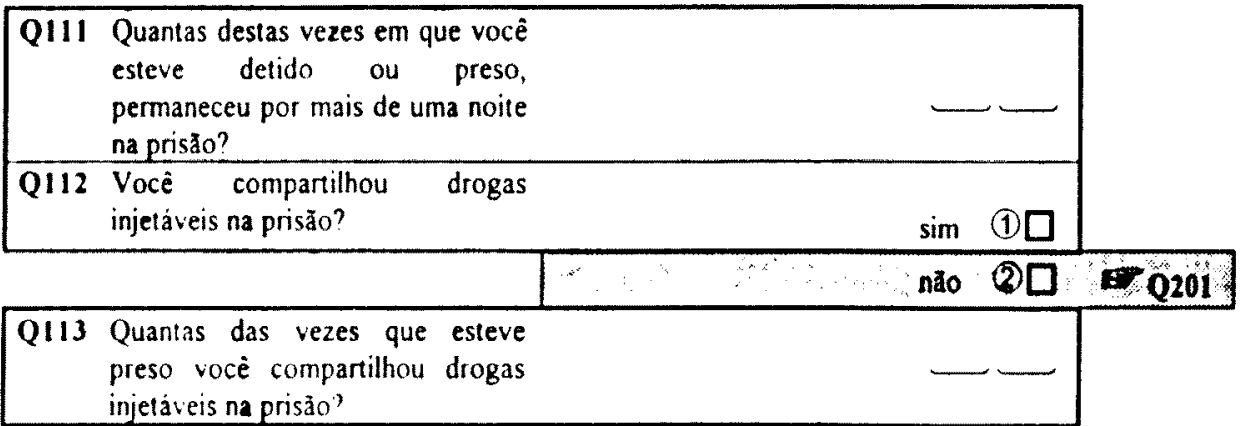

\section{SEÇĀO 2 : CARACTERÍSTICAS DEMOGRÁFICAS}

\begin{tabular}{|c|c|c|}
\hline \multicolumn{3}{|c|}{$\begin{array}{l}\text { Eu gonaria de perguntar-the agora acerca de seus dados bassicos de voce e os de sua } \\
\text { familic. }\end{array}$} \\
\hline Q201 & $\begin{array}{l}\text { Essa cidade é seu local habitual de } \\
\text { residencia? }\end{array}$ & $\begin{array}{l}\text { (1) } \\
\text { (2) }\end{array}$ \\
\hline Q202 & Bairro em que reside? & \\
\hline Q203 & Você sabe ler? & $\begin{array}{l}\text { (1) } \square \\
\text { (2) } \square\end{array}$ \\
\hline Q204 & $\begin{array}{l}\text { Até que série você estudou? } \\
\text { (completos) }\end{array}$ & \\
\hline Q205 & $\begin{array}{l}\text { Ao longo dos últimos } 6 \text { meses, qual sua principal fonte de renda e } \\
\text { sustento? }\end{array}$ & \\
\hline 01 & Empregado com salário regular & (1) $\square$ \\
\hline 02 & Trabalho temporário & $2 \square$ \\
\hline 03 & Em beneficio & (3) \\
\hline 04 & $\begin{array}{l}\text { Contando com a renda do cônjuge } \\
\text { ou parente }\end{array}$ & $\omega \square$ \\
\hline 05 & Autōnomo & $\$ \square$ \\
\hline 06 & Prostituição & $6 \square$ \\
\hline 07 & Outros(especificar) & \\
\hline
\end{tabular}

Q206 Fale alguma coisa sobre quem divide com vocè o local de moradia. Se você wise em casa de cômodos, pode ser sobre as pessoas que dividem cum você comida, objetos, coisas do dia a dia na própia casa Para cada uma destas pessoas, por favor diga-me
-Ela usou droga (de qualquer tipo) nos últimos seis meses

- Ela injetou drogas nos últimos seis meses

-Com que freqüência vocês falaram sobre drogas nos últimos seis meses

- Com que frequência vocês falaram sobre AIDS nos últimos seis meses

código de respostas:

\begin{tabular}{|c|c|c|c|c|}
\hline \multicolumn{2}{|c|}{$\begin{array}{c}\text { Frequentemente } \\
\text { (1) }\end{array}$} & $\begin{array}{l}\text { Raramente } \\
\text { (2) }\end{array}$ & $\begin{array}{l}\text { Nunca } \\
\text { (3) }\end{array}$ & \\
\hline \multicolumn{5}{|c|}{ tipo de relaça com a pessoa } \\
\hline oi) & \multicolumn{2}{|c|}{ Esposa, Marido-Mulher } & (08) & $\begin{array}{l}\text { Filho(a) de outra pessoa } \\
\text { ( não relacionada com você) }\end{array}$ \\
\hline 02) & \multicolumn{2}{|l|}{ Irmå } & 09) & Pai, Padastro, Marido da Mảe \\
\hline 03) & \multicolumn{2}{|l|}{ Immão } & 10) & Parentes de seu(a) Parceiro \\
\hline 04) & \multicolumn{2}{|l|}{ Avô/Avó } & (11) & Mãe, Madastra, Mulher do Pai \\
\hline 05) & \multicolumn{2}{|l|}{ Tio/Tia } & 12) & $\begin{array}{l}\text { Năo relacionado por sangue ou } \\
\text { casamento (amigos, etc) }\end{array}$ \\
\hline 06) & \multicolumn{3}{|c|}{ Namorado, namorada, amasiado } & Outros especificar \\
\hline
\end{tabular}

06) Namorado, namorada, amasiado

07) Filho, enteado

\section{cologuc enpre una resposta}

\begin{tabular}{|l|c|c|c|c|}
\hline Relaçăo & sexo & usa droga & injeta drogas & fala sobre \\
\hline
\end{tabular}

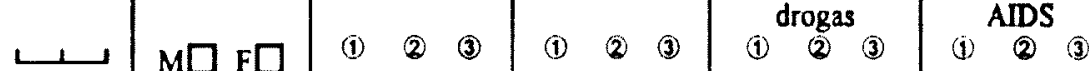

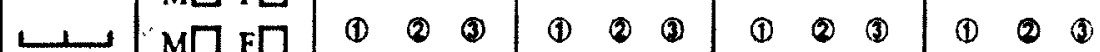

LL $\mathrm{M} \square$ (1) (2) (3)

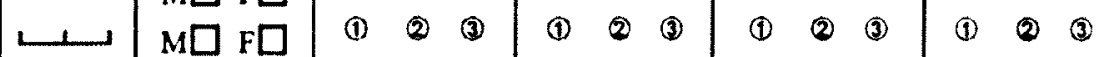

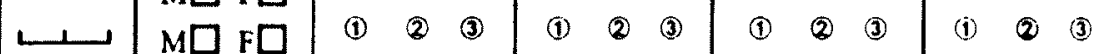

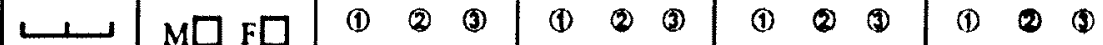

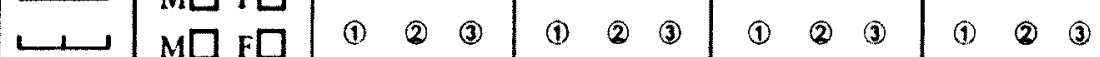

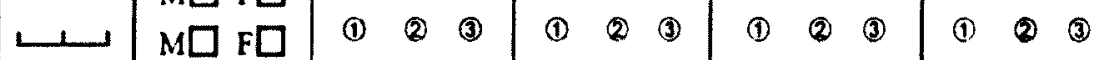

Q207 Agora pense nas três pessoas com as quais você mais conviveu nos últimos seis meses, e que não moram com você. Para cada uma delas diga:

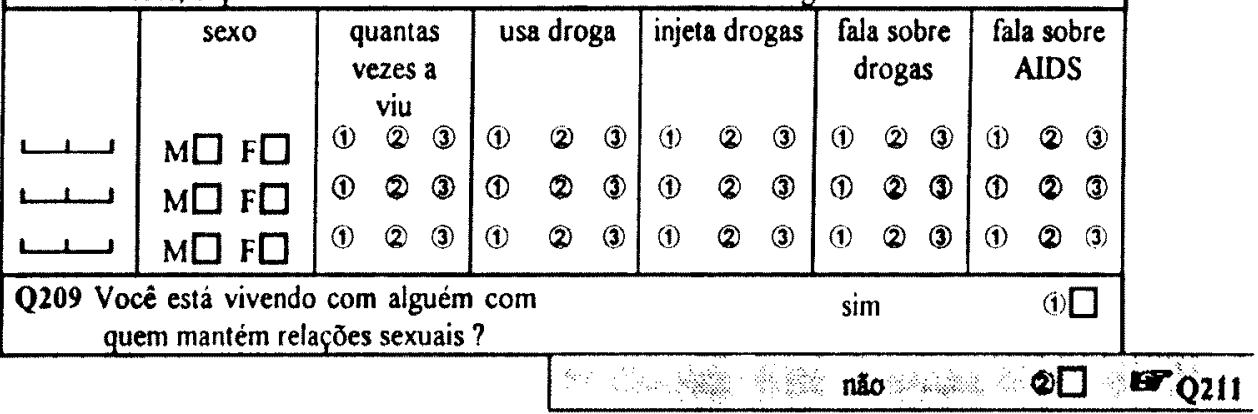




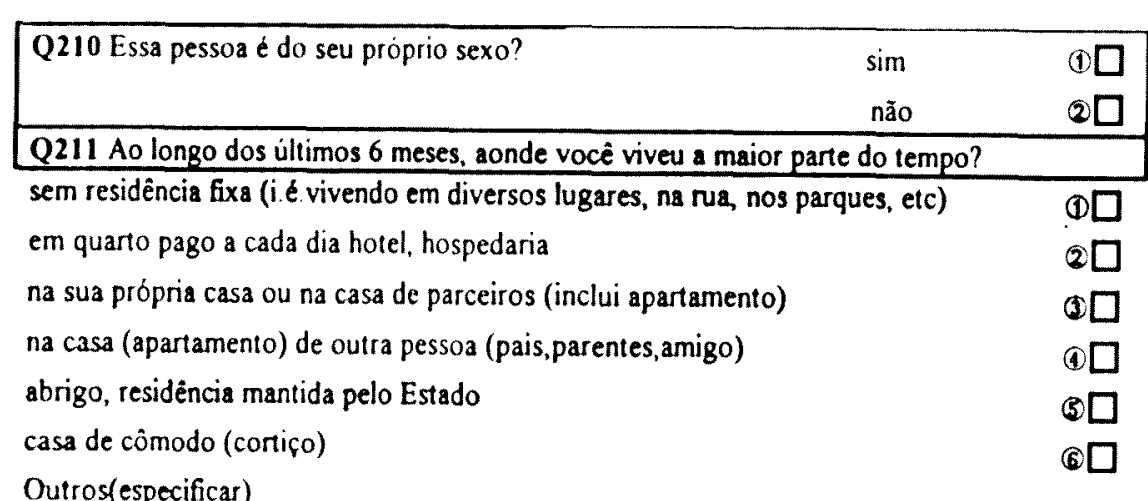

\section{SEÇÃO 3: CONSUMO DE DROGAS}

Eu gostaria de perguntar a vocé agora, algumas questós acerca do uso de drogas ínjetiveis. Q301 Quantos anos você tinha quando se injetou drogas pela primeira vez?

Q302 Qual foi a droga utilizada nesta anos ocasião?

Q303 Em quantos dos últimos seis meses, vocè se injetou drogas?

Q304 Agora perguntarei a vocé algumas questóes sobre drogas que você consumiu nos últimos 6 meses. Para cada droga que eu mencionar, perguntarei se você a utilizou e se a utilização se deu por via injetável?

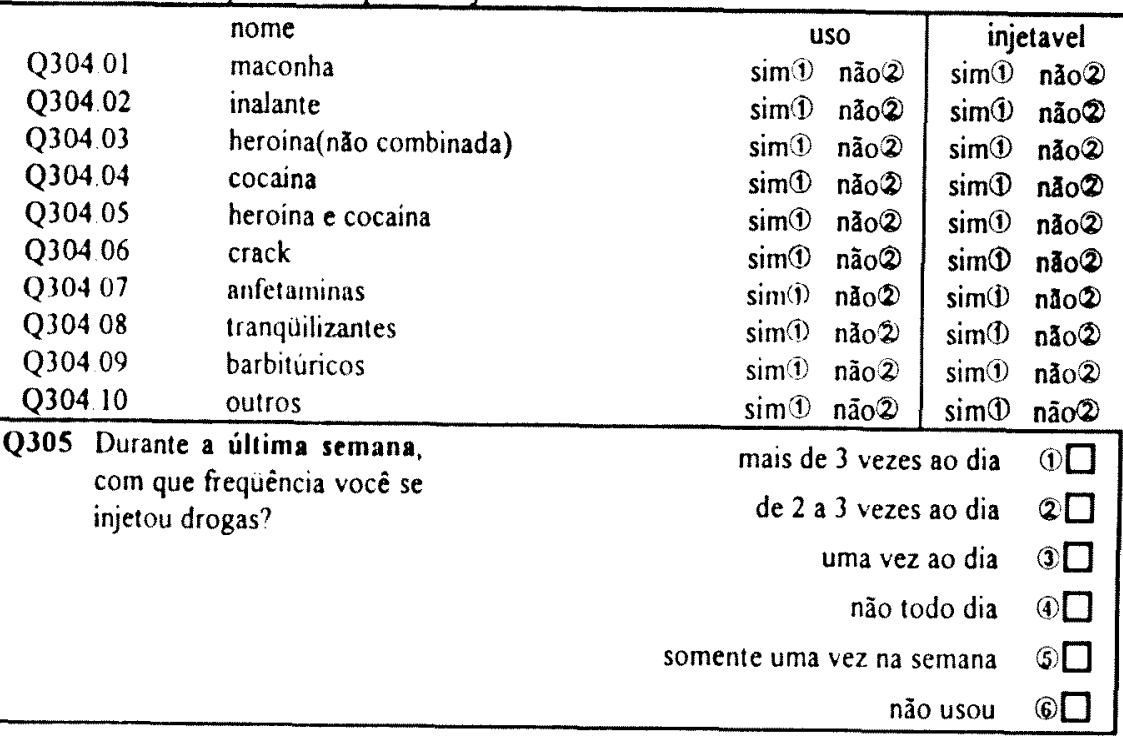

Q306 Durante o último mês, com que frequência você se injetou drogas?

mais de uma vez ao dia, todo dia (1) $\square$

uma vez ao dia, todo dia $2 \square$

toda semana, mas não todo dia (3) $\square$ mais ou menos duas vezes no mês

somente uma vez no mês năo usou $৫ \square$

\begin{tabular}{|c|c|c|c|}
\hline Q307 & $\begin{array}{l}\text { Em quantos dias de um mês típico } \\
\text { você injeta drogas? }\end{array}$ & $L$ & dias \\
\hline Q308 & $\begin{array}{l}\text { Quantas vezes num dia típico vocè } \\
\text { injeta drogas? }\end{array}$ & $\llcorner\perp$ & vezes \\
\hline Q309 & $\begin{array}{l}\text { Quantas vezes vocè reutiliza a } \\
\text { mesma agulha e/ou seringa? }\end{array}$ & 1 & vezes \\
\hline Q310 & $\begin{array}{l}\text { Quantos dias vocè guarda uma } \\
\text { agulha/seringa para reutilizar? }\end{array}$ & \llcorner & dias \\
\hline Q311 & $\begin{array}{l}\text { A cada quantas picadas você tem } \\
\text { que limpar a agulha? }\end{array}$ & 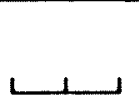 & picadas \\
\hline
\end{tabular}

\section{SEÇÃO 4: COMPARTILHAMENTO DE AGULIIAS E} SERINGAS

\begin{tabular}{|c|c|c|c|}
\hline \multicolumn{4}{|c|}{ 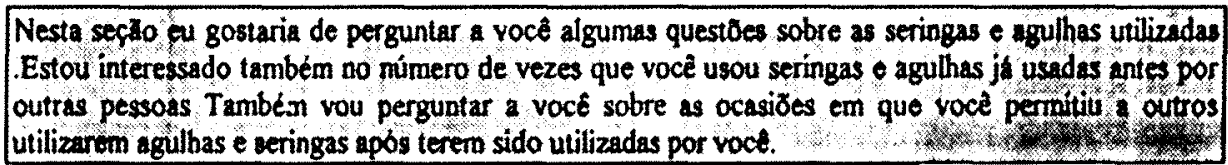 } \\
\hline 401 & $\begin{array}{l}\text { Nos últimos } 6 \text { meses como você obteve agulhas e seringas novas } \\
\text { (que nunca foram usadas antes)? (Não leia os itens para o } \\
\text { entrevistado, codifique mais de um item se necessário Pergunte } \\
\text { apenas utilizando "alguma coisa" mais?) }\end{array}$ & \multirow[b]{2}{*}{$\operatorname{sim}(1) \square$} & \multirow[b]{2}{*}{ 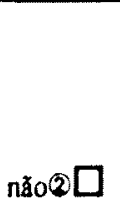 } \\
\hline 01 & Posto de trocas de seringa & & \\
\hline 02 & Farmácia/ outras casas comerciais & $\sin (1) \square$ & nãoฉ口 \\
\hline 03 & Hospital/Centro de Saude & $\sin 1 \square$ & nåอ \\
\hline 04 & Parceiro sexual & $\operatorname{sim}(0 \square$ & nãoข口 \\
\hline 05 & Amigos & $\operatorname{sim}(\overline{0})$ & nãoอ \\
\hline 06 & Não usei seringa nova & $\operatorname{sim}(1) \square$ & nåoข口 \\
\hline 07 & Outras(especificar) & & \\
\hline
\end{tabular}




\begin{tabular}{|c|c|c|c|c|}
\hline Q402 & $\begin{array}{l}\text { Se existirem varias formas, qual a } \\
\text { mais importante dentre elas? }\end{array}$ & (utilize on & questa & ao anterior) \\
\hline Q403 & $\begin{array}{l}\text { Vocé deu agulhas elou seringas } \\
\text { usadas para mais alguém usar? }\end{array}$ & & 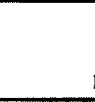 & $\begin{array}{l}\operatorname{sim}(1) \\
\text { não } 0 \square\end{array}$ \\
\hline Q404 & $\begin{array}{l}\text { Vocè já usou drogas injetáveis em } \\
\text { grupo? (entenda como grupo pelo } \\
\text { menos vocè e mais uma pessoa) }\end{array}$ & & & $\begin{array}{l}\operatorname{sim} 0 \square \\
\text { năo } 2 \square\end{array}$ \\
\hline Q405 & $\begin{array}{l}\text { Vocè já compartilhou seringas e } \\
\text { e/ou agulhas com alguém? }\end{array}$ & & & $\begin{array}{l}\operatorname{sim} 0 \square \\
\text { năo } 0 \square\end{array}$ \\
\hline Q406 & $\begin{array}{l}\text { Quando vocé se injetou utilizando } \\
\text { usadas nos últimos } 6 \text { meses, de quem }\end{array}$ & $\begin{array}{l}\text {-se de agulhas e seringas } \\
\text { i vocè as obleve? }\end{array}$ & & \\
\hline 01 & parceiro/a sexual regular & & $\begin{array}{r}\operatorname{sim} \\
\text { nåo } \\
\text { NSA }\end{array}$ & $\begin{array}{l}9 \square \\
2 \square \\
9 \square\end{array}$ \\
\hline 02 & amigo próximo & & $\begin{array}{r}\text { sim } \\
\text { não } \\
\text { NSA }\end{array}$ & $\begin{array}{l}(1) \square \\
6 \square \\
9 \square\end{array}$ \\
\hline 03 & outros(especificar) & & $\begin{array}{r}\text { sim } \\
\text { nåo } \\
\text { NSA }\end{array}$ & $\begin{array}{l}(1) \square \\
(\square \square \\
9 \square\end{array}$ \\
\hline Q407 & $\begin{array}{l}\text { Nos úlimos } 6 \text { meses quando vocè } \\
\text { utilizou agulhas e seringas dadas } \\
\text { ou vendidas a vocè por alguém, } \\
\text { com que frequència vocè as limpou } \\
\text { primeiro? }\end{array}$ & $\begin{array}{r}\text { sempre (100\%) } \\
\text { as vezes } \\
6 \% \text { nunca (0\%) } \\
\text { NSA }\end{array}$ & 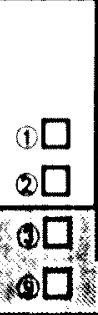 & 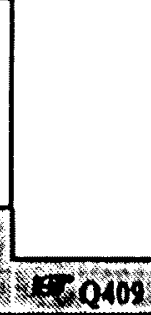 \\
\hline Q408 & $\begin{array}{l}\text { Com o que vocé habitualmente } \\
\text { limpa as agulhas e seringas que } \\
\text { outra pessoa usou? (Não leia as } \\
\text { opçðes para o entrevistado) } \\
\text { (especificar) }\end{array}$ & $\begin{array}{l}\text { água fria } \\
\text { água fervendo } \\
\text { água sanitária } \\
\text { usando álcool }\end{array}$ & $\begin{array}{l}0 \square \\
2 \square \\
3 \square \\
4 \square\end{array}$ & \\
\hline
\end{tabular}

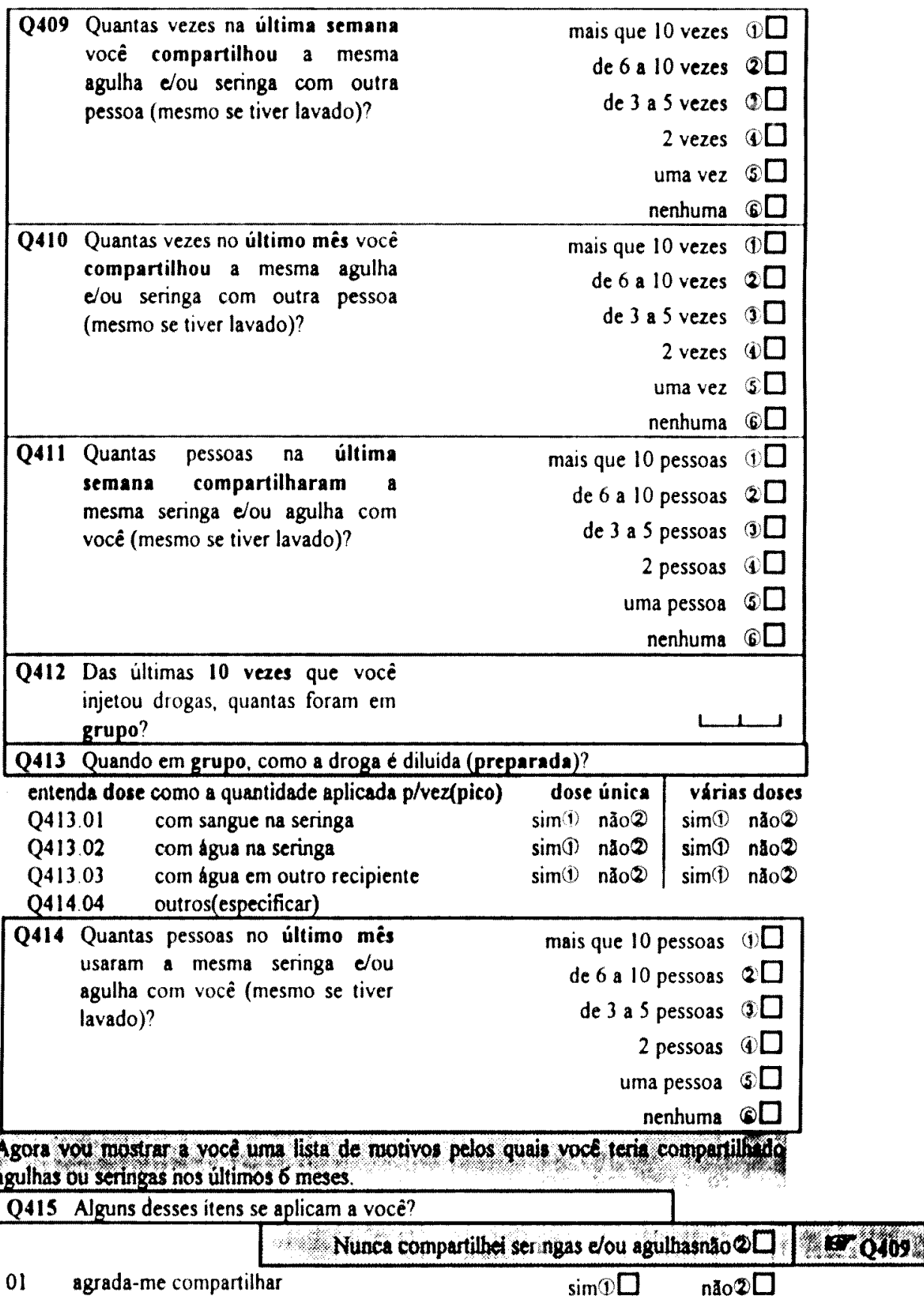


02 eu não possuia minhas proprias agulhas e seringas

03 agulhas e seringas sato dificeis de obter

04 a posse delas năo é segura (medo)

05 não quero gastar dinheiro com seringas e sim com drogas

nenhum motivo em especial

segurança (medo de overdose)

outros

Q416 O que vocè acha de existirem postos de troca de seringas agulhas? (Onde se trocam seringas usadas por novas, onde seja distribuido material para limpar seringas além de distribuir camisinhas e folhetos informativos)

\section{SEÇÃO 5: COMPORTAMENTO SEXUAL}

entenda por parceiro principal alguém que é seu parceiro sexual mais importanté.

Q501 Quantas pessoas você considera

atualmente como seu(s) parceiro(s)

sexual(is) principal(is)?

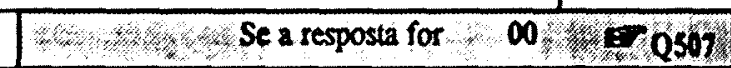

Q502Quantas vezes na última semana você teve relaçðes sexuais vaginais com alguém do sexo oposto que vocé considera parceiro principal?

$\begin{array}{rr}\text { nehuma } & \text { (1) } \square \\ \text { I a } 2 \text { vezes } & 2 \square \\ 3 \text { a } 6 \text { vezes } & \text { (3) } \square \\ \text { ou mais vezes } & \text { (4) } \square\end{array}$

7 ou mais vezes (1) $\square$

Năo tenho parcelo principal do sexo oposto $\quad$ \&

\begin{tabular}{|c|c|c|c|}
\hline$\overline{Q 503}$ & $\begin{array}{l}\text { Quantas vezes na última semana } \\
\text { você teve relaçóes sexuais anais } \\
\text { com alguém do sexo oposto que } \\
\text { você considera parceiro principal? }\end{array}$ & $\begin{array}{r}\text { nehuma } \\
1 \text { a } 2 \text { vezes } \\
3 \text { a } 6 \text { vezes } \\
7 \text { ou mais vezes }\end{array}$ & $\begin{array}{l}\text { (1) } \\
2 \square \\
3 \square \\
6 \square\end{array}$ \\
\hline$\overline{Q 504}$ & $\begin{array}{l}\text { Quantas vezes no último mês você } \\
\text { teve rela es sexuais vaginais com } \\
\text { alguém do sexo oposto que você } \\
\text { considera parceiro principal? }\end{array}$ & $\begin{array}{r}\text { nehuma } \\
\text { I a } 2 \text { vezes } \\
3 \text { a } 6 \text { vezes } \\
7 \text { ou mais vezes }\end{array}$ & $\begin{array}{l}\text { (1) } \square \\
2 \square \\
3 \square \\
\text { (4) } \square\end{array}$ \\
\hline
\end{tabular}

\begin{tabular}{|c|c|c|c|}
\hline Q505 & $\begin{array}{l}\text { Quantas vezes no último mês vocề } \\
\text { teve relações sexuais anais com } \\
\text { alguém do sexo oposto que você } \\
\text { considera parceiro principal? }\end{array}$ & $\begin{array}{r}\text { nehuma } \\
\text { I a } 2 \text { vezes } \\
3 \text { a } 6 \text { vezes } \\
7 \text { ou mais vezes }\end{array}$ & $\begin{array}{l}6 \square \\
2 \square \\
3 \square \\
(4 \square\end{array}$ \\
\hline Q506 & $\begin{array}{l}\text { Com que frequêencia você usou } \\
\text { camisinha ao manter relações } \\
\text { sexuais com seu parceiro principal? }\end{array}$ & $\begin{array}{r}\text { sempre }(100 \%) \\
\text { na maioria das vezes } \\
\text { cerca de metade das ocasiðes } \\
\text { ocasionalmente } \\
\text { nunca }(0 \%)\end{array}$ & $\begin{array}{l}0 \square \\
2 \square \\
1 \square \\
6 \square \\
5 \square\end{array}$ \\
\hline
\end{tabular}

Entenda como parceiro ocasional alguem que nao o seu parceiro principal mais importante ou cliente.

507 Quantas pessoas você considera aualmente como seu(s) parceiro(s) sexual(is) ocasionais?

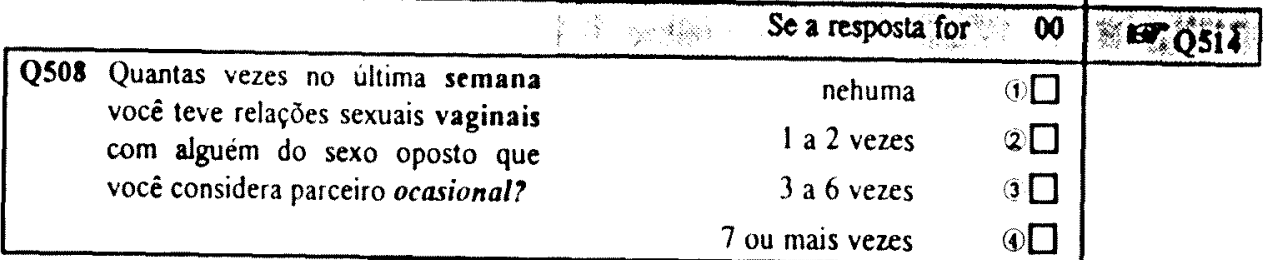

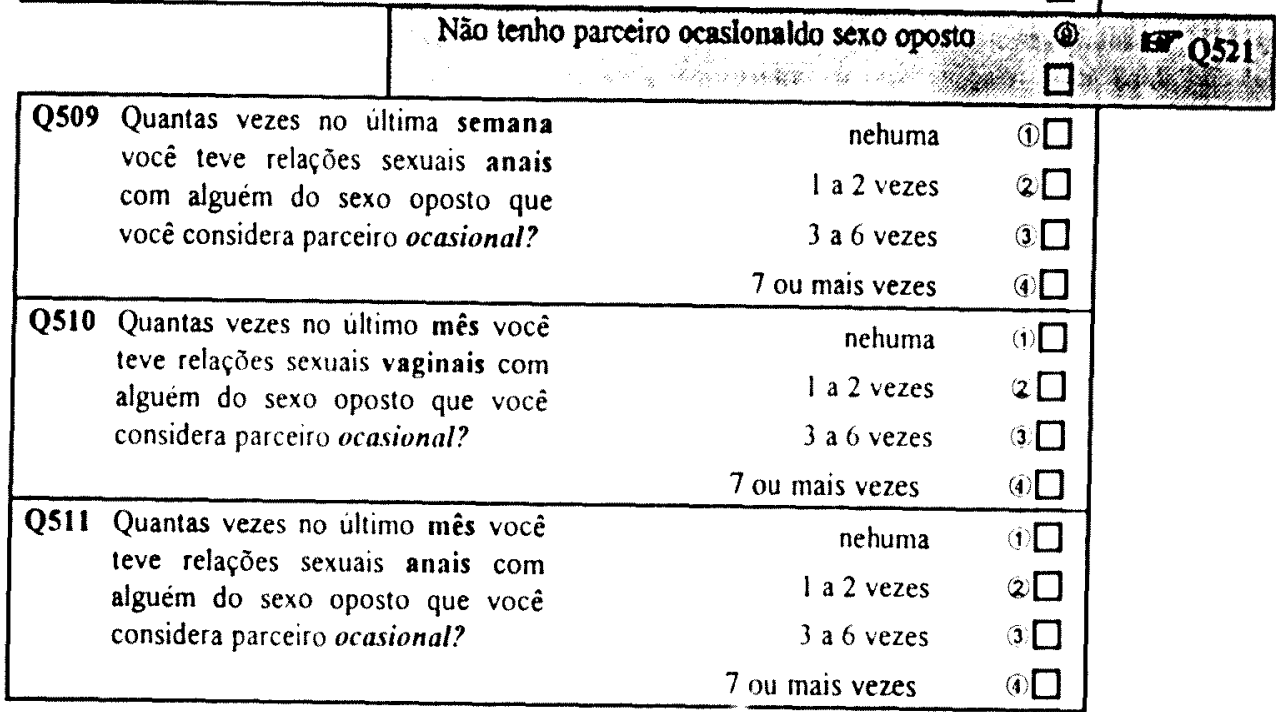




\begin{tabular}{|c|c|c|c|}
\hline Q512 & $\begin{array}{l}\text { Com que frequência vocè usou } \\
\text { camisinha ao manter relaçðes } \\
\text { sexuais com parceiro ocasional? }\end{array}$ & $\begin{array}{r}\text { sempre }(100 \%) \\
\text { na maioria das vezes } \\
\text { cerca de metade das ocasiðes } \\
\text { ocasionalmente } \\
\text { nunca }(0 \%)\end{array}$ & $\begin{array}{l}6 \square \\
2 \square \\
3 \square \\
6 \square \\
6 \square\end{array}$ \\
\hline Q513 & $\begin{array}{l}\text { Você alguma vez recebeu de alguma } \\
\text { pessoa presente, dinheiro, bens ou } \\
\text { drogas em troca de relação sexual? }\end{array}$ & $\operatorname{sim}$ & (1) $\square$ \\
\hline
\end{tabular}

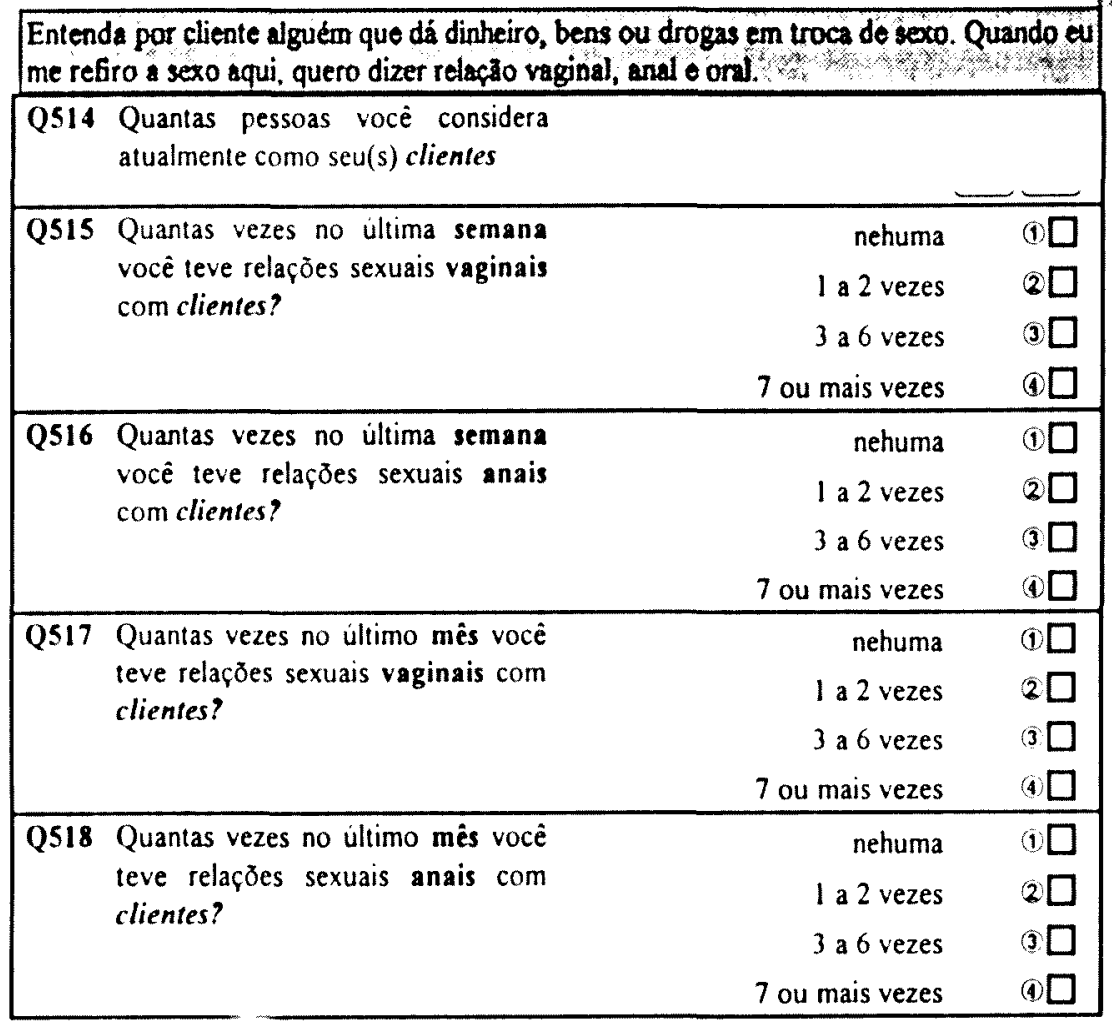

\begin{tabular}{|c|c|c|}
\hline $\begin{array}{l}\text { Q519 Com que frequência você usou } \\
\text { camisinha ao manter relaçðes } \\
\text { sexuais com clientes? }\end{array}$ & $\begin{array}{r}\text { sempre (100\%) } \\
\text { na maioria das vezes } \\
\text { cerca de metade das ocasiðes } \\
\text { ocasionalmente } \\
\text { nunca }(0 \%)\end{array}$ & $\begin{array}{l}9 \square \\
2 \square \\
3 \square \\
\text { (4) } \square \\
6 \square\end{array}$ \\
\hline
\end{tabular}

SE A ENTREVISTADA FOR MULHER passe para a questho ( w w SOMENTE PARA HOMENS

\begin{tabular}{|c|c|c|c|}
\hline Q521 & $\begin{array}{l}\text { Você alguma vez teve relação } \\
\text { sexual com parceiros do próprio } \\
\text { sexo? }\end{array}$ & $\begin{array}{l}\text { sim } \\
\text { não }\end{array}$ & $\begin{array}{l}\text { (1) } \square \\
2 \square\end{array}$ \\
\hline Q520 & $\begin{array}{l}\text { Com que frequência vocè teve } \\
\text { relaçðes sexuais (anal/oral) com } \\
\text { outro homem, incluindo travesti, } \\
\text { nos últimos } S \text { anos (incluindo } \\
\text { periodo passado na prisăo ou } \\
\text { relação sob coaçăo) }\end{array}$ & $\begin{array}{r}\text { mais que } 10 \text { vezes } \\
\text { de } 6 \text { a } 10 \text { vezes } \\
\text { de } 3 \text { a } 5 \text { vezes } \\
2 \text { vezes } \\
\text { uma vez }\end{array}$ & $\begin{array}{l}1 \square \\
2 \square \\
3 \square \\
9 \square \\
5 \square\end{array}$ \\
\hline
\end{tabular}

\begin{tabular}{|c|c|c|c|}
\hline Q521 & $\begin{array}{l}\text { Nos últimos } 6 \text { meses com que } \\
\text { frequência você teve relação sexual } \\
\text { anal com um parceiro do mesmo } \\
\text { sexo? }\end{array}$ & $\begin{array}{r}\text { mais que } 10 \text { vezes } \\
\text { de } 6 \text { a } 10 \text { vezes } \\
\text { de } 3 \text { a } 5 \text { vezes } \\
2 \text { vezes } \\
\text { uma vez } \\
\text { nenhuma }\end{array}$ & $\begin{array}{l}6 \square \\
6 \square \\
3 \square \\
9 \square \\
(5 \square \\
6 \square\end{array}$ \\
\hline Q522 & $\begin{array}{l}\text { Nos últimos } 6 \text { meses com que } \\
\text { frequência você utilizou camisinha } \\
\text { ao manter relaçòes sexuais anais } \\
\text { com um parceiro do mesmo sexo? }\end{array}$ & $\begin{array}{r}\text { mais que } 10 \text { vezes } \\
\text { de } 6 \text { a } 10 \text { vezes } \\
\text { de } 3 \text { a } 5 \text { vezes } \\
2 \text { vezes } \\
\text { uma vez } \\
\text { nenhuma }\end{array}$ & $\begin{array}{l}6 \square \\
2 \square \\
3 \square \\
5 \square \\
5 \square \\
6 \square\end{array}$ \\
\hline
\end{tabular}




\section{SECÃO 6:CONHECIMENTO A CERCA DA AIDS E MODIFICAÇÕES DE COMPORTAMENTO}

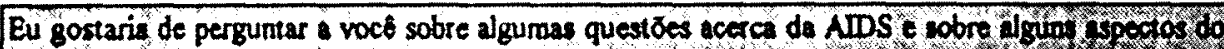

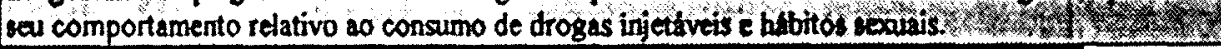

Q601 Nos últimos 12 meses você teve contato ou envolvimento com alguma atividade de prevenção de AIDS?

$$
\sin \quad 1 \square
$$

0602 Qual?

Q603 Você acredita que alguém possa ser portador do virus da AIDS e ter um aspecto saudavel?

.

\begin{tabular}{rr} 
sim & $1 \square$ \\
não & $2 \square$ \\
não sei & $3 \square$ \\
\hline
\end{tabular}

Q604 Vocè poderia me dizer como uma pessoa pode ser infectada com o virus da AIDS? Diga todos os modos que souber:

O1 Näo conhece nenhum meio de con
\begin{tabular}{ll}
\hline uso de drogas \\
02
\end{tabular}
$\begin{aligned} & \text { utilizando drogas(sem menção ao } \\
& \text { compartilhamento de agulhas) } \\
& \text { Injetando drogas (sem menção ao } \\
& \text { compartilhamento de agulhas) } \\
& \text { compartilhando apetrechos para } \\
& \text { injeçăo de drogas } \\
& 05 \quad \text { outros(especificar) }\end{aligned}$
200 306060

AIDS contato sexual

06 atividade sexual (heterosexual)

atividade sexual (homosexual)

relaçăo anal

relaçăo vaginal

sexo oral

atividade sexual com uma pessoa infectada

12 praticando sexo na vigência de uma doença sexualmente transmissivel

ou ferida $g$ nital

13 praticando sexo sem preservativo

14 outras (especificar)

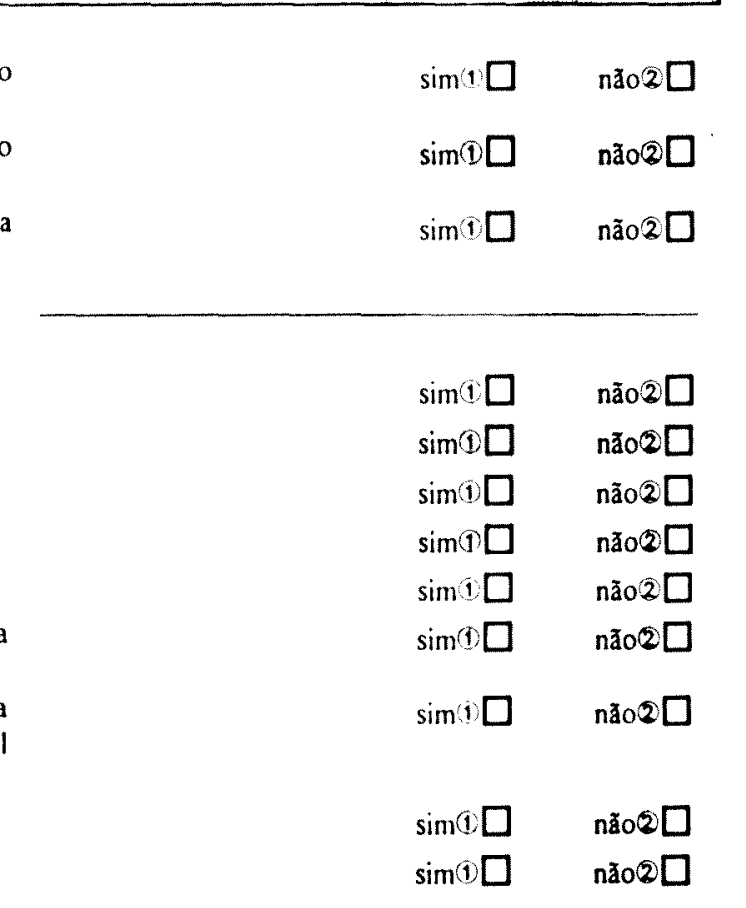

\section{transfusto}

15 transfusăo de sangue elou derivados

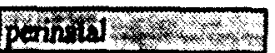

16 bebês podem se contaminar das

\section{mães}

comatio ocastion

$\operatorname{sim}(1) \square$

não

17 bejjando

$\sin \theta \square$

กรัดอ

18 de banheiro

19 compartilhando xicaras, copos, garfos e outros utensilios

$\sin 0 \square$

$\sin \oplus \square$

nมัว $\square$

20 tocando pessoas que tem AIDS

21 saliva

22 escovando os dentes com a mesma escova de outra pessoa

23 permanecendo no mesmo ambiente com alguém que é portador do víns 24 outros(especificar todos)

outras

25 mosquitos

26 contato acidental com sangue

$\sin 0 \square$

$\sin (0)$

nIov $\square$

27 tatuagem

28 outros(especificar todos)

Q605 Desde que vocé ouviu falar em AIDS, você tomou alguma providência no sentido de não se contaminar com o virus?

$\sin (1) \square$ nฐo2 $\square$

\section{SEÇÃO 7 :HISTÓRIA DE VIAGENS}

\begin{tabular}{|c|c|c|c|}
\hline Q701 & $\begin{array}{l}\text { Você injetou drogas fora do } \\
\text { perimetro desta cidade nos ultimos } \\
2 \text { anos? }\end{array}$ & $\sin (0) \square$ & กณ๊ంด \\
\hline Q703 & $\begin{array}{l}\text { Você compartilhou agulhas e } \\
\text { seringas em alguns destes lugares? }\end{array}$ & $\sin \theta \square$ & noo 0 \\
\hline
\end{tabular}




\section{Seção 8:TESTAGEM PARA HIV}

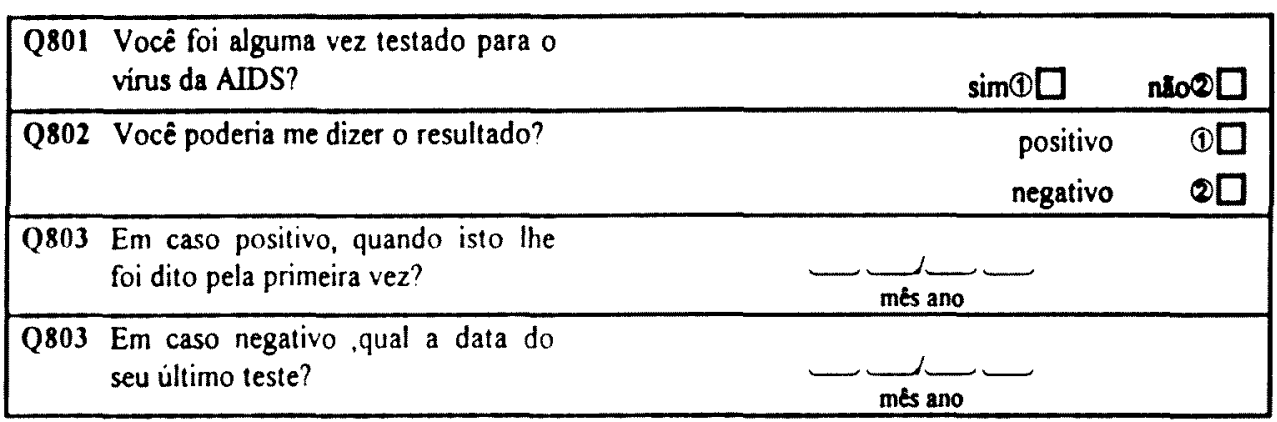

CASO UMA AMOSTRA SEJA COLHIDA POR FAVOR CERTIFICAR-SE DE QUE TODAS AS ETAPAS DESCRITAS NO PROTOCOLO SEJAM RIGOROSAMENTE SEGUIDAS

SE O ENTREVISTADO NĀO CONCORDAR EM FORNECER UMA AMOSTRA DE SANGUE, PERGUNTE POR QUE, E ANOTE ABAIXO AS RAZÕES DA RECUSA.

AGRADECA AO ENTREVISTADO/A PELA SUA COLABORAÇÃO E AVISELHE QUE O QUESTIONÁRIO ESTÁ PREENCHIDO.

Observações adicionais 
VIII.3 - Questionário do Estudo III, com consentimento informado. 
Estudo Multicêntrico de HIV e outras consequências à saúde do uso de drogas injetáveis

Estudo de soroprevalença e comportamento entre usuários de drogas injetaveis (UDIs) na regiño da Baixada Santista e em outras 20 cidades do mundo.

Estudo de Diagnóstico Rápido de Drogas

Consentincnto lnformado para Participação na Pesquisa

A - Objetivos do Estudo:

O presente projeto de pesquisa tem como objetivo estudar comportamentos de risco para a transmissão do HIIV e outras doenças entre UDls.

A coordenação deste projeto na Baixada Santista esta a cargo do Dr Fábio C Mesquita, do ILPAS e do NUPAIDS/USP (LIM 01).

B-Procedimentos:

Se eu concordar em participar deste estudo deverei:

1. responder a um questionário a cerca de dados pessoais, comportamentos de risco para o contagio pelo HIIV e outros problemas de saúde.

2. serão colhidos de 10 a $20 \mathrm{mls}$ de meu sangue para realização de testes para o HIV e outras doenças infecciosas.

3. Tu receberei confidencialmente os resultados dos exames, se assim o desejar.

4. Lu receberei uma quantia de R\$ 10,00 (dez reais) equivalente ao meu tempo dispendido com o listudo e gasto com transporte à titulo de ajuda de custo.

5. A entrevista durará cerca de 40 minutos.

( - Riscos e Desconfortos:

Todos os exames serão realizados com material descartável. Os riscos referentes ao exame serão minimos, iguais aos de qualquer exame laboratorial de sangue.

Confidencialidade: cu receberei, se assim o desejar, pessoalmente, os resultados de meus exames. Estes resultados não serão revelados a terceiros, a menos que eu assim o desejar mediante aulorização por escrito.

Meus dados pessoais serão arquivados em locais seguros a que só terão acesso os responsáveis pelo projeto. Minha identidade pessoal não será mencionada em qualquer hipotese Us dados publicados serão referentes ao conjunto de pessoas participantes do Estudo. de forma a não permitir a identificação de qualquer um dos participantes

1)-Duvidas 
Em caso de dúvidas ou comentários adicionais acerca deste projeto poderei me comunicar com o Dr Fábio Mesquita coordenador do projeto no IEPAS, a Av Campos Sales, 59, Santos, S.P., tel: 013.2354842

E- Consentimento:

A participação neste Estudo é absolutamente voluntária. Eu poderei abandonar este Estudo, a qualquer momento, sem prejuizo pessoal. Contarei com apoio da coordenação, independentemente de minha participação ou não na pesquisa, no sentido de obter orientação quanto ao aconselhamento e eventual tratamento médico no caso de resultado positivo em quaisquer dos exames laboratoriais realizados e/ou em atenção à solicitaðões individuais.

Eu li este formulário, e recebi as explicações necessárias da/do

entrevistador

Código do Entrevistado؟

Data, local

Entrevistador

Lhitrevístado

Recebi do IEPAS, a quantia de R\$ 10,00, pela minha participação como entrevistado (para despesas de lanche e condução) na pesquisa "Estudo Multicêntrico de IIIV e outras consequências à saúde do uso de drogas injetáveis"realizado na Baixada Santista

data:

assinatura. 


\section{SEÇÃO A: INFORMAÇÕES SOBRE A ENTREVISTA \\ E RECRUTAMENTO}

QA01- Número de identificaçào da entrevista de UD

QA02- Numero de identificaçào do projeto

$\mathrm{BS} / \mathrm{BR}$

QA03- Numero do codigo do entrevistador

QA05- De onde esta sendo recrutado o entrevistado?

I Centro de Tratamento de pacientes de drogas (ambulatório)

2 Centro de Tratamento de pacientes de drogas

3 Prisào

4 Lugar publico/rua

5 Lugar privado

- Outros (especificar)

QA(O)- O entrevistado esta sendo entrevistado sozinho ou com acompanhante?

1 Sozinho

2 Acompanhado

QA07- Qual sua data de nascimento?

Nome da Màe

QA118- Sexo
I Masculino
2 Feminino
3 Transsexual

QAl0- Cidade onde mora
1 Santos
2 São Vicente
3 Guaruja
+ Prara Grande
5 Cubatão
6 Bertioga
7 Itanhahem
8 Mongagua
9 Peruibe
10 Outros em São Paulo

11 Outros no Brasil 


\section{SECÃO B: DEMOGRÁFICA}

QB!I- EII qual pais vocé nasceu?

(especificar)

(cód. do centro)

QB02- Desde quando vocè mora na Baixada Santista? meses

QB03- Qual seu grau de escolaridade ( anos completos de estudo)? ( se não estudou, cod."00")

$\mathrm{XBO4-}$

QB05- Durante os ultumos o meses. qual foi sua principal fonte de renda para viver? (Nâo leıa as opçōes de resposta cırcule uma resposta).

01 Emprego com salario regular (integral ou meio periodo)

02 Emprego temporario (incluindo " bicos ")

03 Negocio de familia ou terreno agricola.

()) Autönomo

05 Beneficios governamentais (seguro desemprego, etc.)

06 Ajuda de renda de parentes. amigos. conjuge. etc.

(1) A Auda financeıra Doaçào/Emprestumo

1) 8 Esmolar/Mendigar

(1) Vendendo Drogas

10) Prostituiçào.

II Furto/Roubo

12 Atuvidades ilegais

13 Cameló

98 Recusa-se a responder a questào

Outros (especificar)

$\overline{\text { local }} \overline{\text { cod. }}$

QBOG- Vocé está morando sozınho atualmente?

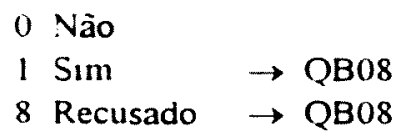

(IB07- Vocé mora com algumlus das seguintes pessoas (na mesma casa)?

(Leia cada categoria Circule uma resposta para cada).

I Parceiro sexual. do sexu oposto

2 Parcerro sexual, do mesmo sexo

3 Seus pals

4 Outro parente adulto (mator de 18 anos) sem ser parcerro sexual

5 Seu fillıol a) (biologico/adotivo/de criação)

- Crianças que nào sào suas

7 Almigos Não Sim Rec.

$0 \quad 18$

$\begin{array}{lll}0 & 1 & 8\end{array}$

8 Outros adultos. sem ser parceiros sexuais ou anigos

$\begin{array}{lll}0 & 1 & 8\end{array}$

$\begin{array}{lll}0 & 1 & 8\end{array}$

$0 \quad 18$

$\begin{array}{lll}0 & 1 & 8\end{array}$

$\begin{array}{lll}0 & 1 & 8\end{array}$

$\begin{array}{lll}0 & 1 & 8\end{array}$ 
QB08- Qual seu estado civil? (Circule uma resposta).

1 Legalmente casado (a)

2 Mora junto $\quad \rightarrow \quad$ QB 10

3 Viuvo (a) $\rightarrow \quad$ QB 10

4 Legalmente separado(a) $\rightarrow \quad$ QB 10

5 Divorciado (a) $\rightarrow$ QB 10

6 Solteiro (a) $\quad \rightarrow \quad$ QB 10

7 Separado (a) $\rightarrow$ QB 10

8 Recusada a resposta $(\operatorname{Rec}.) \rightarrow$ QB 10

QB09- Você e seu cônjuge moram juntos?

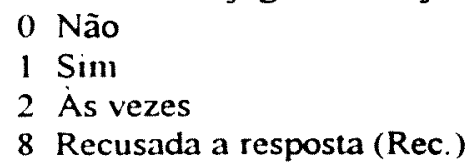

QB10- Onde vocé morou a maior parte do tempo nos últimos seis meses?

(Não leia as opções de resposta circule uma resposta)

$01 \mathrm{Na}$ minha própria casa (companheiro ou cônjuge), flat ou apartamento (propriedade não alugada)

02 Casa. flat ou aparamento ou quarto alugado por $\mathrm{mim}$ (companheiro ou cônjuge)

03 Pensão ou hotel

04 Casa, flat ou apartamento de alguém (incluindo pais, parentes ou amigos)

05 Alojamento para funcionários públicos.

06 Abrigo/Albergue

07 Sem endereço fixo (prédio abandonado, rua, parque)

08 Comunidade residencial

09 Instituição de trabalho de drogas

10 Hospital/Outra instituição de tratamento

11 Prisão

12 Cortiço

13 Favela

98 Recusa-se a responder ( $\mathrm{Rec}$.) Outros

(especificar) cod. Tocal

QB11- Agora, pense sobre a classe social da sua familia, a qual você cresceu e compare com a classe social do pais como um todo. Qual a classe social da sua familia?

(Leia todas as opçōes - exceto recusa, circule uma resposta)

01 Muito Rica

02 Rica

03 Classe Média

04 Pobre

05 Muito Pobre

97 Nào cresceu em uma familia

98 Recusa-se a responder (Rec.) 
XB12- Qual sua atual classe social?

(Leia todas as opcões - exceto recusa. circule uma resposta)

01 Muito Rica

02 Rica

03 Classe Média

04 Pobre

05 Muito Pobre

98 Recusa-se a responder (Rec.) 


\section{SEÇÃO C: INFORMAÇÕES}

\section{$\checkmark$ (Pergunte somente se o entrevistado foi recrutado fora de local de tratamento)}

QC01- Alguma vez você recebeu algum tratamento que tivesse a intenção de modificar seu uso de drogas?
0 Não
$\rightarrow \quad \mathrm{QC08}$
$1 \mathrm{Sim}$
8 Recusa-se a responder
$\rightarrow$ QC08

- Vou perguntar à você sobre tipos de tratamentos de drogas que você recebeu desde quando começou a usar drogas. Para cada tipo de tratamento diga-me se você foi paciente interno, externo, com tratamento domiciliar ou ambos.

Diga-me se você teve esse tratamento uma, duas, três vezes ou mais em sua vida. Estou interessado(a) no número de tratamentos, e não no número de seções individuais. Lembrese que estamos falando somente no número de tratamentos para ajudar você a reduzir ou parar de usar drogas.

Algum (tipo de tratamento)?

QC02(Se "Sim")

Quantas vezes no tipo ambulatório?

QC03-

Quantas vezes em clinica de internação?

Repetir as questôes para cada item. Coloque "O" para nenhum, "I"para uma vez,

" 2 "para duas vezes, " 3 " para três vezes ou mais).

QC02

Amb./ ou

Hosp.dia

01 Tratamento Clinico Particular 90

02 Tratamento Clínico Público

03 Casa de Apoio Religioso

04 Grupo de Auto-Ajuda

05 Outros

(especificar)

06 Outros

07 Outros

$$
\text { (especificar) }
$$

\section{1}

92

02
QC03

Int./ou

Resid.

(especificar)

$\triangle$ (Perguntar somente se o entrevistado foi recrutado fora de local de tratamento).

QC04- Você está recebendo tratamento de drogas atualmente?

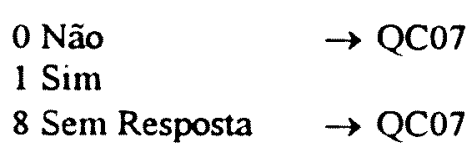

QC05- Você começou seu tratamento nos últimos 30 dias?
0 Não
$1 \mathrm{Sim}$
8 Sem Resposta 
QC06- Que tıpo de tratamento você está recebendo atualmente?

(Use códigos QC02/QC03)

$$
\frac{}{\text { cód. centro }} \rightarrow \mathrm{QC08}
$$

QC07- Ha quantos meses atrás recebeu seu último tratamento para modificar seu uso de drogas?

(Investigue a melhor estimativa .Se "nunca" ou " nenhum "escreva "000". Se dentro do último mès escreva "00I". Se " faz muito tempo para lembrar" escreva "995").

meses atrás

QC08- Você jả esteve preso (a)?
0 Não
$\rightarrow$ QC12
$1 \mathrm{Sim}$
8 Sem resposta
$\rightarrow \mathrm{QC12}$

QC09- Quantas vezes você já esteve preso (a)?

$$
\text { Mostrar o cartão } D
$$

I 1 vez

22 vezes

3 3-5 vezes

4 6-10 vezes

5 mais de 10 vezes

8 Sem resposta

QC10- Você injetou drogas na prisão?
0 Não
$1 \mathrm{Sim}$
$\rightarrow$ QC12
8 Sell resposta
$\rightarrow$ QC12

QC11- Quando você injetou drogas na prisão, você usou agulhas e/ou seringas usadas anteriormente por outra pessoa?
0 Não
$1 \mathrm{Sim}$
8 Sem resposta
9 Não sabe 
QC12- Com que frequência, nos últimos 6 meses, você teve contato ou envolvimento com as seguintes atividades de prevenção à AIDS?

(Leia cada item, e circule uma resposta para cada)

Mostre o cartão $A$
A- Nunca
B- Menos de 1 vez por mês
C- $1-3$ vezes por mês
D- 1 vez por semana
E- 2-3 por semana

01 Aconselhamento em grupo

02 Aconselhamento individual

03 Palestra em grupo

04 Informação individual

05 Abordagem na rua por Agentes ou Redutores

06 Veiculo de massa (TV, Rádio,Jornal)

07 Teste HIV

08 Fornecimento de hipoclorito de sódio

09 Fornecimento de camisinhas

10 Programa de Troca de Agulhas/Seringas

11 Organização de usuário de Drogas

12 Cartazes ou Folhetos de campanha

13 Máquina de camisinha

14 Outros

15 Outros

\author{
F- 4-6 por semana \\ G- Quase 1 vez por dia \\ H- 2 - 3 vezes por dia, quase todos os dias \\ I- 4 ou mais vezes ao dia, quase todos os dias \\ J- Recusou-se a responder
}

\section{Frequência de Contato}

\begin{tabular}{llllllllll}
\multicolumn{3}{c}{ Por / mês } & \multicolumn{3}{c}{ Por/semana } & Por/ Dia \\
0 & $<1$ & $1-3$ & 1 & $2-3$ & $4-6$ & 1 & $2-3$ & $4+$ & $R$
\end{tabular}

$\begin{array}{llllllllll}\text { A } & \text { B } & \text { C } & \text { D } & \text { E } & \text { F } & \text { G } & \text { H } & \text { I } & \text { J } \\ \text { A } & \text { B } & \text { C } & \text { D } & \text { E } & \text { F } & \text { G } & \text { H } & \text { I } & \text { J } \\ \text { A } & \text { B } & \text { C } & \text { D } & \text { E } & \text { F } & \text { G } & \text { H } & \text { I } & \text { J } \\ \text { A } & \text { B } & \text { C } & \text { D } & \text { E } & \text { F } & \text { G } & \text { H } & \text { I } & \text { J }\end{array}$

$\begin{array}{llllllllll}A & B & C & D & \text { E } & \text { F } & \text { G } & \text { H } & \text { I } & \text { J }\end{array}$

$\begin{array}{llllllllll}A & B & C & D & E & F & G & H & l & J\end{array}$

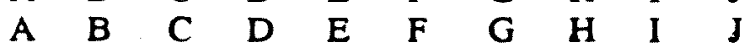

$\begin{array}{llllllllll}A & B & C & D & E & F & G & H & \text { I } & \text { J }\end{array}$

$\begin{array}{llllllllll}A & B & C & D & E & F & G & H & I & J\end{array}$

$\begin{array}{llllllllll}A & B & C & D & \text { E } & \text { F } & \text { G } & \text { H } & \text { l } & \text { J }\end{array}$

$\begin{array}{llllllllll}A & B & C & D & \text { E } & F & G & H & \text { I } & \text { J }\end{array}$

$\begin{array}{llllllllll}\text { A } & \text { B } & \text { C } & \text { D } & \text { E } & \text { F } & \text { G } & \text { H } & \text { I } & \text { J }\end{array}$

$\begin{array}{llllllllll}A & B & C & D & E & F & G & H & \text { I } & \text { J }\end{array}$

$\begin{array}{llllllllll}A & B & C & D & E & F & G & H & I & J\end{array}$

$\begin{array}{llllllllll}A & B & C & D & E & F & G & H & I & J\end{array}$ 


\section{SEÇÃO D: USO DE DROGAS}

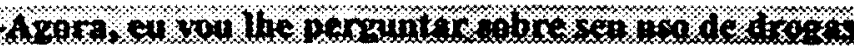

ఇD01- Quantos anos você tinha quando usou pela primeira vez cigarros/tabaco?

(Se nunca escreva “00")

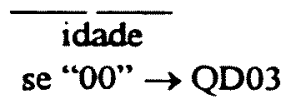

QD02- Quantos cigarros você fuma por dia?

QD03- Quantos anos você tinha quando consumiu pela primeira vez bebida alcóolica?

(se nunca escreva "00”)

QD04- Você consumiu bebida alcóolica nos últimos 6 meses?

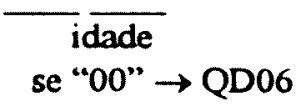

$$
\begin{aligned}
& \text { não } 0 \\
& \operatorname{sim} 1
\end{aligned} \rightarrow \text { QD06 }
$$

XD05- Em um dia típico quantos copos de bebida você toma? (Não leia as respostas. Circule uma resposta).

$$
\begin{array}{ll}
0 & \text { Nenhum } \\
1 & \text { Um } \\
2 & \text { Dois } \\
3 & \text { Três à cinco } \\
4 & \text { Seis ou mais } \\
8 & \text { Sem resposta }
\end{array}
$$

QD06- Você usou maconha ou haxixe nos últimos. 6 meses?

$$
\begin{array}{r}
\text { Não } 0 \\
\text { Sim } 1 \\
\text { recusou-se a responder } 8
\end{array}
$$

QD07- Quantos anos você tinha quando usou pela primeira vez outras drogas do tipo heroina, outros narcóticos opiáceos, cocaína, anfetaminas outros estimulantes barbitúricos, tranquilizantes, inalantes, solventes esteróides, etc. Não contar com drogas usadas para propósitos medicinais.

$$
\text { idade }
$$

QD08- Qual droga usada?

$$
\text { especificar cód }
$$

QD09- Ao longo de sua vida você já injetou drogas, exceto para propósitos medicinais?

Não 0

$\operatorname{Sim} 1 \rightarrow$ QD20

recusou-se a responder $8 \rightarrow$ Termine 
- Se o entrevistado ao longo de sua vida injetou, pule para a sub seção INJETORES ou EXUSUÁRIOS.

- Se insiste em dizer que recusa-se a responder se tem se injetado, termine a entrevista. 


\section{SUB-SEÇÃO D: NUNCA INJETOU}

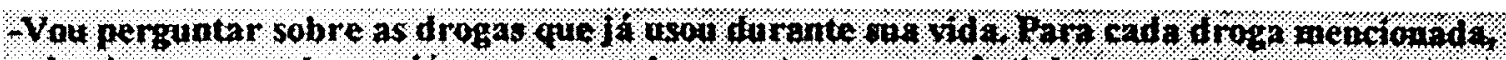
pröneiro quero saber se já asou; segunda, quantos anas vocé tinha quando usou pela primeiro

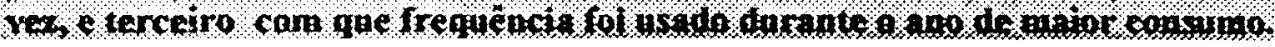

QD10-

Você já usou ? ( nome da droga).

(se usou)

QD11-

Quantos anos você tinha quando usou pela primeira vez?

QD12-

Qual a frequencia de uso durante o ano de maior consumo? [repetir essas perguntas para cada droga]

Mostre o cartão A
A- Nunca
B- Menos de 1 vez por mês
C. $1-3$ vezes por mês
D- 1 vez por semana
E - 2-3 por semana
F- 4-6 por semana
G- Quase 1 vez por dia
H- $2-3$ vezes por dia, quase todos os dias
I- 4 ou mais vezes ao dia, quase todos os dias
J- Recusou-se a responder

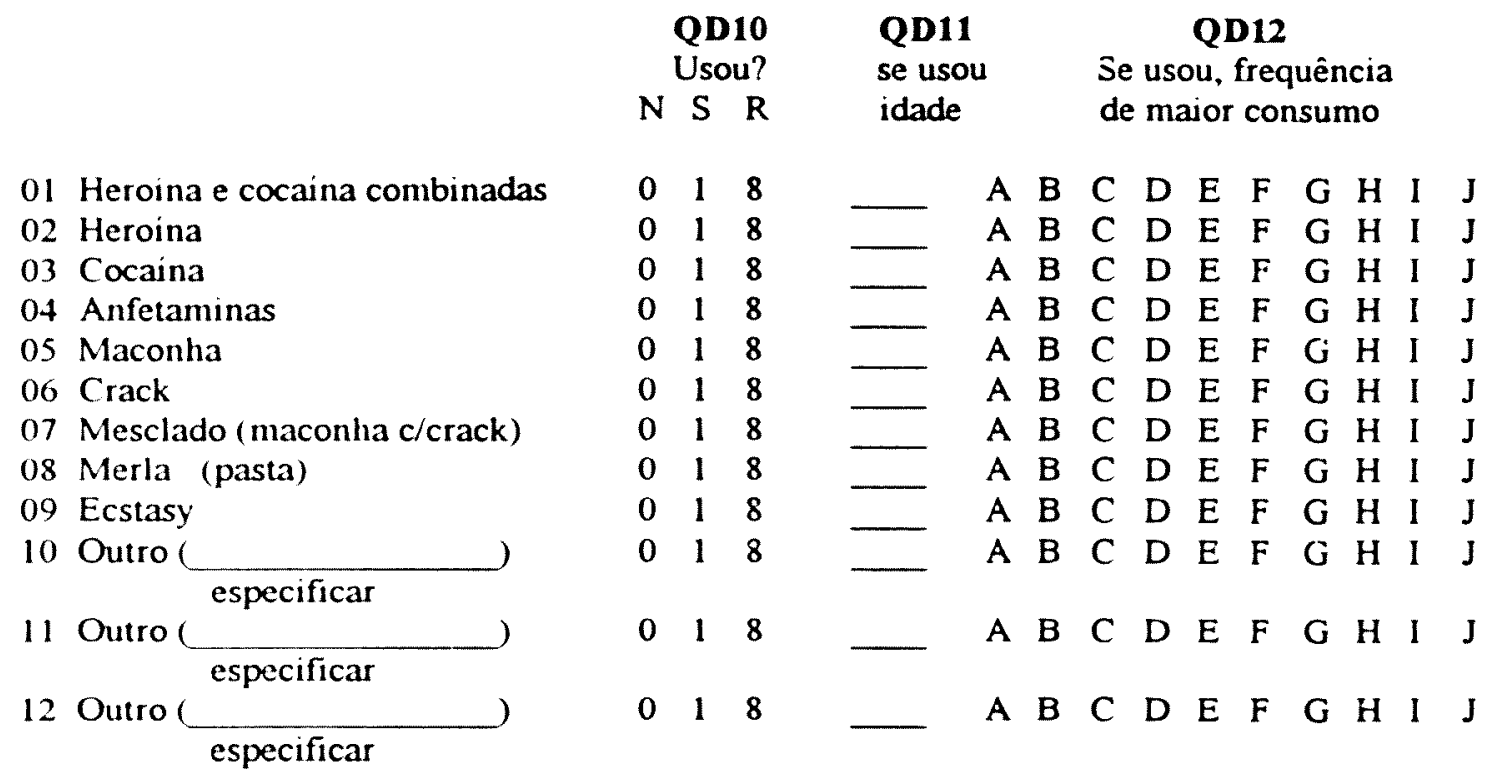

QD13- Você tem amigos ou parentes que injetam drogas frequentemente?
0 Não
$\rightarrow$ QD16
$1 \mathrm{Sim}$
7 Não aplicável (Nem amigos ou parentes) $\rightarrow$ QD16
8 Recusou-se a responder (Rec.)
$\rightarrow$ QD16 
QD14- Quantos? (Amigo ou Parente)

(Não leia as opções. Circule uma resposta)

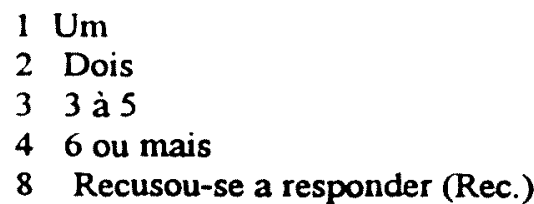

XD15- Algum(s) dos seguintes abaixo:

(Leia cada item. Circule uma resposta para cada)

1 Parceiro Sexual

2 Membros da familia que não são parceiros sexuais

3 Amigos próximos

Não Sim Rec.

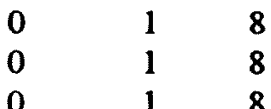

QD16- Nos últimos 6 meses, você usou drogas enquanto outra pessoa estava injetando drogas no mesmo lugar?

0 Não

$1 \mathrm{Sim}$

8 Recusou-se a responder (Rec.)

9 Não sabe/Não lembra

QD17- Por que você sempre usou métodos de não injeção em lugar de métodos de injeção? (Não leia a lista. Circule mais de um "sim" se mencionada, pergunte somente "alguma coisa mais"?)

mencionado

Não Sim

01 Tentativa de controlar/reduzir/eliminar o uso da droga

02 Preocupação com as consequências da injeção para a saúde

03 Preocupação em contrair HIV/AIDS

04 Preocupação em contrair hepatite

05 Mais fácil de controlar as doses, evitando overdose

$06 \mathrm{Medo} / \mathrm{Não}$ gostar de agulhas/seringas ou sangue

07 Evitar marcas ou outro estigma.

08 Evitar o envolvimento com a lei.

09 Utensilios de injeção não estavam disponiveis

10 Drogas injetáveis são muito caras.

11 Mais conveniente, fácil, rápido as não injetáveis.

12 Satisfação com o resultado das não injetáveis

13 Pressão dos iguais/Desejo de ser como os amigos/parceiros

14 Por causa do preconceito social sobre injeção

15 Não me vejo como injetor

16 Poderia causar desgraça familiar (pşicológica, econômica, etc.)

17 Costume com drogas não injetáveis, nunca pensou em injetáveis

18 Sem contato com injetores/não frequenta esses grupos

19 Nunca houve oportunidade.

20 Não ser a fim

21 Sem motivo especial

22 Outros

23 Outros

(especificar)

$\begin{array}{ll}0 & 1 \\ 0 & 1 \\ 0 & 1 \\ 0 & 1 \\ 0 & 1 \\ 0 & 1 \\ 0 & 1 \\ 0 & 1 \\ 0 & 1 \\ 0 & 1 \\ 0 & 1 \\ 0 & 1 \\ 0 & 1 \\ 0 & 1 \\ 0 & 1 \\ 0 & 1 \\ 0 & 1 \\ 0 & 1 \\ 0 & 1 \\ 0 & 1 \\ 0 & 1 \\ 0 & 1 \\ & \\ 0 & 1\end{array}$

(especificar) 
Vamos falar sobre sen aso de drogas $n 00$ fifamas 6 meses

QD 18- Em quantos dos últimos 6 meses você usou drogas

meses

se "0" $\rightarrow$ Termine

- Eu vou the perguntar sobre algumas drogas especificas que rocé usou nos altimos 0 meses. De cada droga mencionada, preciso saber sobre a frequência em que toran usadas nesses nieses.

QD19- Qual frequência que você usou ? (nome da droga)

(Repita a pergunta para cada droga)

Mostre o cartão A
A- Nunca
B- Menos de I vez por m as
F- 4-6 por semana
C- $1-3$ vezes por mês
G- Quase 1 vez por dia
D- 1 vez por semana
H- 2 - 3 vezes por dia, quase todos os dias
E - 2-3 por semana
I- 4 ou mais vezes ao dia, quase toros os dias
J- Recusou-se a responder

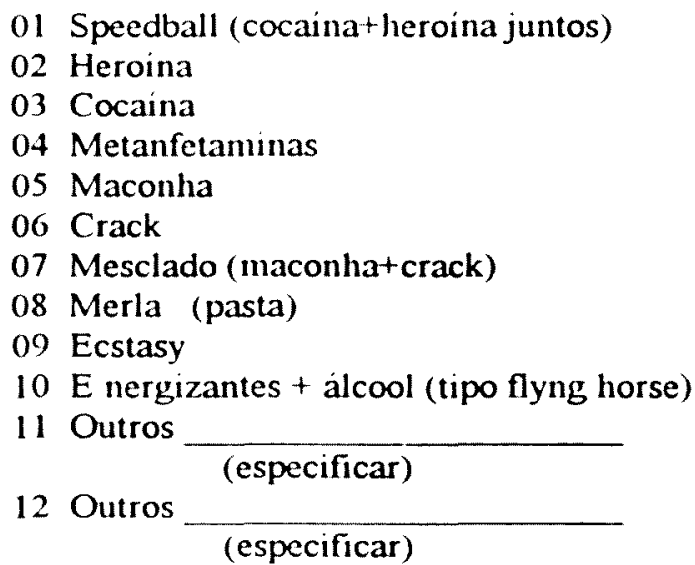

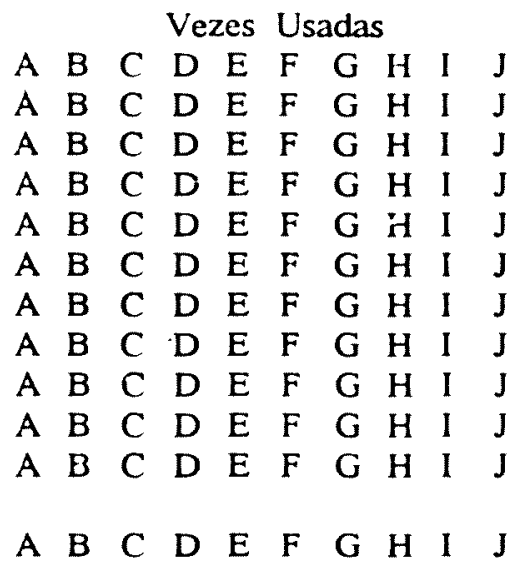

Omitir o restante da seção 1 , seção $E$ e seção $F$, pular para seção $G$ (op̧̧ão local) ou seção $H$

$\rightarrow$ Sec.G

ou Sec.H 


\section{D: SUB SECĀO PARA INJETORES OU EX-INJETORES}

-Agora eu quero que voce pense na primeira vez que lajetou droga, excluindo o uso medicimal.

QD20- Quantos anos você tinha quando injetou drogas pela primeira vez?

$$
\text { idade }
$$

QD21 - Qual foi esta droga?

$$
\text { especificar }
$$

QD22- Alguma vez vocē usou esta mesma droga antes de ser injetada?

$$
\begin{array}{lll}
\text { Não } & 0 & \rightarrow \text { XD25 ou QD26 } \\
\text { Sim } & 1 & \\
\text { nder } & 8 & \rightarrow \text { XD25 ou QD26 }
\end{array}
$$

QD23- Com que frequência você estava usando esta mesma droga, no periodo de 30 dias anteriores a primeira vez que a injetou?

Mostre o cartão A
A- Nunca
F- 4-6 por semana
B- Menos de I vez por mês
G- Quase 1 vez por dia
C- $1-3$ vezes por mês
H- $2-3$ vezes por dia, quase todos os dias
D- 1 vez por semana
I- 4 ou mais vezes ao dia, quase todos os dias
E- 2-3 por semana
J- Recusou-se a responder

QD24- Quantos anos você tinha quando usou esta mesma droga de qualquer maneira de administração?

idade

XD25- Durante os 30 dias anteriores à sua primeira injeção, você usou algumas das seguintes drogas?

( Leia cada categoria de droga. Circule uma resposta para cada)

1 Speedball (heroina + cocaina juntas)

2 Heroina

3 Cocaina

4 Anfetaminas

5 Maconha

6 Crack

7 Mesclado

8 Merla

9 Ecstasy

10 Outra ( especificar

Não Sim Rec. Não Sabe
11 Outra especificar
12 Outra especificar

$\begin{array}{llll}0 & 1 & 8 & 9 \\ 0 & 1 & 8 & 9 \\ 0 & 1 & 8 & 9 \\ 0 & 1 & 8 & 9 \\ 0 & 1 & 8 & 9 \\ 0 & 1 & 8 & 9 \\ 0 & 1 & 8 & 9 \\ 0 & 1 & 8 & 9 \\ 0 & 1 & 8 & 9 \\ 0 & 1 & 8 & 9 \\ 0 & 1 & 8 & 9 \\ 0 & 1 & 8 & 9\end{array}$


QD26 A primeira vez que você injetou drogas, quem estava injetando em você? Que tipo de relacionamento ele/ela tinha com você.

(Não leia as opções. Circule uma resposta)

01 Eu mesmo(a)

02 Parceiro sexual principal

$\rightarrow$ QD28

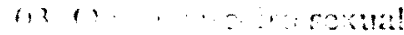

US Amigo intimo

06 Outro amigo intimo ou conhecido

07 Traficante/Distribuidor

08 Alguém que não conhecia bem

09 Outrox

\section{especificar}

98 Recusou-se a responder (Rec.)

99 Não se lembra

QD27- Qual o sexo desta pessoa?

I Masculino

2 Feminino

3 Outros

8 Recusou-se a responder ( $\operatorname{Rec}$.)

9 Não se lembra

QD28- Da primeira vez, que você se injetou a seringa e a agulha eram usadas?

o Não

1 Sim

8 Recusou-se a responder $(\operatorname{Rec}$.

9 Não se lembra 


\section{MÓdULO DE OPÇÃO LOCAL NO INÍCIO DA INJEÇĀO}

XD29- Quando você se injetou pela primeira vez, estava na Baixada Santista?
0 Não
1 Sim
8 Recusou-se a responder (Rec.)

$\rightarrow \mathrm{XD} 31$

XD30- Qual cidade você estava quando se injetou pela primeira vez?

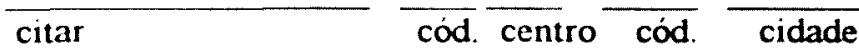

XD31- Na cidade em que você se injetou pela primeira vez, você pensa que o uso de drogas injetáveis era raro, mais ou menos, ou muito difundido na época.
1 Raro
2 Mais ou menos
3 Muito difundido
8 Recusou-se a responder) Rec.
9 Não se lembra

XD32- Em qual tipo de lugar você se injetou pela primeira vez?

(Não leia as opções. Circule uma resposta)

01 Onde eu morava

02 Na casa do parceiro sexual

$03 \mathrm{Na}$ casa de parentes

$04 \mathrm{Na}$ casa de amigos

$05 \mathrm{Na}$ casa de outra pessoa

$06 \mathrm{Num}$ abrigo/albergue

$07 \mathrm{Na}$ escola/faculdade

08 Num lugar "seguro" para injeção

09 Na casa do traficante, em "galeria de uso" ou outro lugar para uso de drogas

10 Fora de galeria de uso ou outro lugar de uso de drogas

11 Em um bar/clube

$12 \mathrm{Em}$ um espaço público (rua, parque,prédio abandonado, banheiro público, terreno baldio, etc.)

13 Em um carro ou veiculo similar

98 Recusou-se a responder (Rec.)

99 Não se lembra

Outro especificar

XD33- Da primeira vez que você injetou drogas, como conseguiu a droga?

(Não leia as opções. Circule uma resposta).
1 Ganhei
2 Comprei
3 Dei dinheiro para alguém comprar
4 Troquei por sexo
5 Outro
6 Eu era traficante
8 Recusou-se a responder ( Rec.)
9 Não me lembro 
XD34- Por que começou a injetar drogas?

(Não leia as opçōes. Circule mais de um "sim" se mencionado. Pergunte somente "algo mais")

01 Tipo/Qualidade de droga disponivel inadequada para outra forma de uso (não injetável)

02 Achei que fosse ficar mais alto mais depressa

03 Meus amigos/companheiros estavam injetando e resolvi tentar

04 Pressão dos amigos/companheiros

05 Preocupação com a saude, em consequências de cheirar/aspirar

06 Estava em uma festa e os outros estavam fazendo

07 Curiosidade

08 Estava deprimido/problemas

09 Todos estavam fazendo

10 Dinheiro insuficiente para comprar a droga

15 Outro especificar mencionada
Não Sim

16 Outro

especificar

\begin{tabular}{|c|c|}
\hline 0 & \\
\hline 0 & \\
\hline 0 & \\
\hline 0 & \\
\hline 0 & \\
\hline 0 & \\
\hline 0 & \\
\hline 0 & \\
\hline 0 & \\
\hline 0 & \\
\hline 0 & \\
\hline
\end{tabular}

XD35- Antes da sua primeira experiência com drogas injetáveis, você achou que fosse usar apenas uma ou duas vezes, e então pararia, ou que se tornaria um hábito regular.

1 Tentar 1 ou 2 vezes e parar

2 Tornar-se um injetor regular

8 Recusou-se a responder

9 Não sabe

XD36- Antes da sua primeira injeção, você conhecia alguéin que tivesse tido problemas sérios por usar drogas injetaveis?
0 Não
1 Sim
8 Recusou-se a responder
9 Não sabe/não tem certeza

XD37- Antes da sua primeira injeção, você já tinha ouvido falar em HIV ou AIDS?
0 Não
1 Sim
8 Recusou-se a responder
9 Não sabe / não tem certeza

XD38- Antes da sua primeira injeção, você conhecia alguém que tivesse AIDS?
0 Não
$1 \mathrm{Sim}$
8 Recusou-se a responder
9 Não sabe / não tem certeza 
XD39- Antes da primeira injeção, você sabia que injetando drogas, poderia adquirir HIV ou AIDS?

0 Não

1 Possivelmente, mas não muito provável

2 Provavelmente

8 Recusou-se a responder

9 Não sabe / não tem certeza

XD40-

XD41-

XD42-

XD43-

XD44-

XD45-

XD46-

XD47-

QD48- Alguma vez você iniciou ou introduziu alguém no uso de drogas injetáveis?

Não - 0

Sim -1

Recusou-se a responder -8

QD49- Quantos anos você tinha quando começou a injetar drogas pelo menos uma vez por semana de forma regular?

( Se nunca injetou regularmente, escreva "00") idade

QD50- Durante sua vida, quantas vezes você injetou drogas?

(Não leia as opcôes. Circule uma resposta)

1 Somente uma vez

22 a 9 vezes (poucas vezes)

310 a 99 vezes

4100 a 999 vezes

51000 vezes ou mais

8 Recusou-se a responder

QD51- Qual seu método básico de tomar drogas agora?

( Leia as opções exceto recusa de responder. Circule uma resposta)

1 Injeção

2 Não injeção

3 Amats

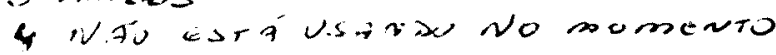

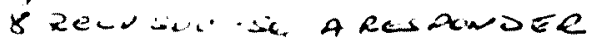

QD52- Quantos meses atrás você injetou drogas pela última vez?

(Estimule a melhor resposta. Se respondeu último mês escreva "001".

Se "faz muito tempo para lembrar" escreva "995")

Se o cntrevistado não se injetou durante os últimos seis meses, pule para seção de ex-mletores. Se injetou nos últimos seis meses mas recusa-se a detalhar, classifique como ex metador e pule para $Q D 60$.

Se nâo der para classificar termine a entrevista 


\section{D: SUB SEÇÃO PARA INJETORES}

Agora, iremos falar sobre seu uso do dromes nos allinos 6 meses.

QD53- Quantas meses dos últimos 6 meses você injetou drogas?

$$
\frac{\text { meses }}{\text { se "6" } \rightarrow \text { QDS5 }}
$$

XD54- Por que você teve alguns meses sem injetar nos últimos 6 meses? (Não leia a lista. Circule mais de um "sim"se mencionado. Pergunte "algo mais?").

Mencionado

Não Sim

01 Tentando controlar/reduzir/eliminar o uso da droga

02 Preocupação com a saúde em consequência da injeção

03 Preocupação em contrair HIV/AIDS

04 Preocupação em contrair hepatite

05 Mais fácil de controlar as doses, evitando a overdose

$06 \mathrm{Medo} /$ não gosta de agulhas/seringas ou sangue

07 Não quero marcas ou outros estigma

08 Evitar o envolvimento com a lei

09 Não encontramos utensilios de injeção

10 Drogas injetáveis são muito caras

11 Mais conveniente, fácil, rápido as não injetáveis

12 Satisfação com o resultado das não injetáveis

13 Pressão dos iguais/compartilhar da companhia de amigos/parceiros

14 Por causa do preconceito social sobre drogas injetáveis

15 Nào me vejo como um injetador

16 Poderia causar desgraça familiar(psicológica, econômica etc.)

17 Eu normalmente não injeto drogas o tempo todo

18 Varia com outro tipo de droga ou forma de admissão

19 Outro )

especificar

$\begin{array}{ll}0 & 1 \\ 0 & 1 \\ 0 & 1 \\ 0 & 1 \\ 0 & 1 \\ 0 & 1 \\ 0 & 1 \\ 0 & 1 \\ 0 & 1 \\ 0 & 1 \\ 0 & 1 \\ 0 & 1\end{array}$

01

$0 \quad 1$

$0 \quad 1$

01

01

0 1

01

0 1

20 Outro $\underbrace{}_{\text {especificar }}$

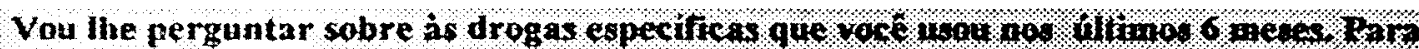

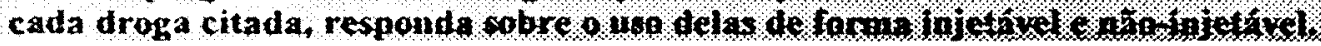


QD55-

Com que frequência você injetou (nome da droga)

XD56-

Com que frequência você usou (nome da droga) sem injetar? (Repita a questão para cada categoria de droga)

Mostre o cartão A
A- Nunca
B- Menos de 1 vez por mamens
C- $1-3$ vezes por mês
D- 1 vez por semana
E - 2-3 por semana

F- 4-6 por semana

G- Quase 1 vez por dia

$\mathrm{H}-2-3$ vezes por dia, quase todos os dias

I- 4 ou mais vezes ao dia, quase todos os dias

J- Recusou-se a responder

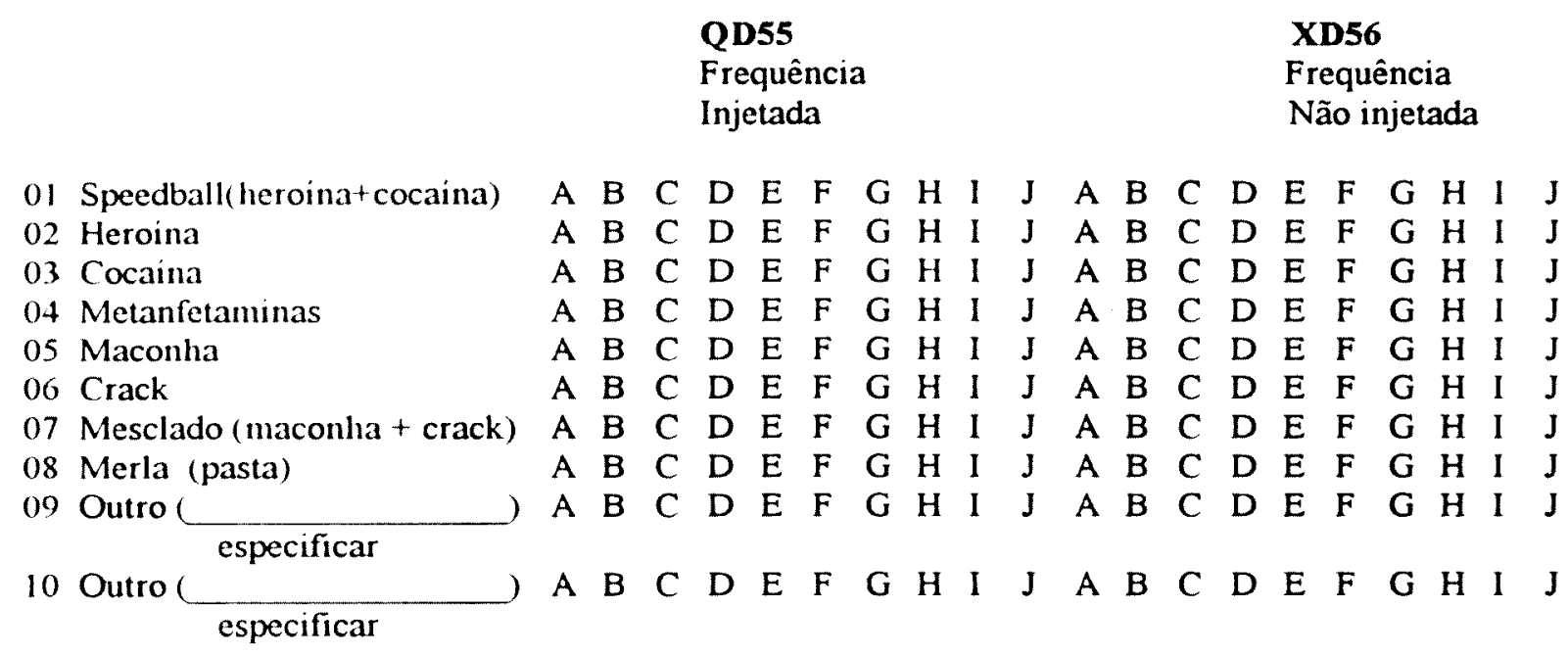

\section{Agora, quero que você pense sobre seu uso de dragas injetaveis de um modo geral, nos} últinzos 6 meses.

QD57- Nos meses em que você se injetou, com que frequência você ofez?

Mostre o cartão A
A- Nunca
B- Menos de 1 vez por sem in
C- $1-3$ vezes por mês
D- 1 vez por semana
E - 2-3 por semana
F- 4-6 por semana
G- Quase 1 vez por dia
H- $2-3$ vezes por dia, quase todos os dias
I- 4 ou mais vezes ao dia, quase todos os dias
J- Recusou-se a responder

QD58- Durante os últimos 6 meses, num mês típico, quantos dias por mês você se injetava?

dias

QD59- Durante os últimos 6 meses, na média de um dia, quantas vezes por dia você se injetava? $\rightarrow$ Sec.E

Omta o restante da seçâo l) e pule para seção E. 


\title{
D. SUB SEÇĀO PARA EX-INJETORES
}

Agora, vamos falar sobre seu uso de drogas nos últimos 6 meses. Vou the perguntar especificameate sobre as drogas que voré usou nos f́ltimos 6 meses. Para cada droga citada, aos meses en que vocé usou, cu quero ubber sobre a frequêncin de usa.

QD60-

Com que frequéncia você usou ? (nome da droga)

(Repita a questão para cada categoria de droga)

Mostre o cartão A
A- Nunca
B- Menos de 1 vez por mês
C- $1-3$ vezes por mès
D- 1 vez por semana
E - 2-3 por semana

\author{
F- 4-6 por semana \\ G- Quase 1 vez por dia \\ $\mathrm{H}-2-3$ vezes por dia, quase todos os dias \\ I- 4 ou mais vezes ao dia, quase todos os dias \\ J- Recusou-se a responder
}

Frequência de uso

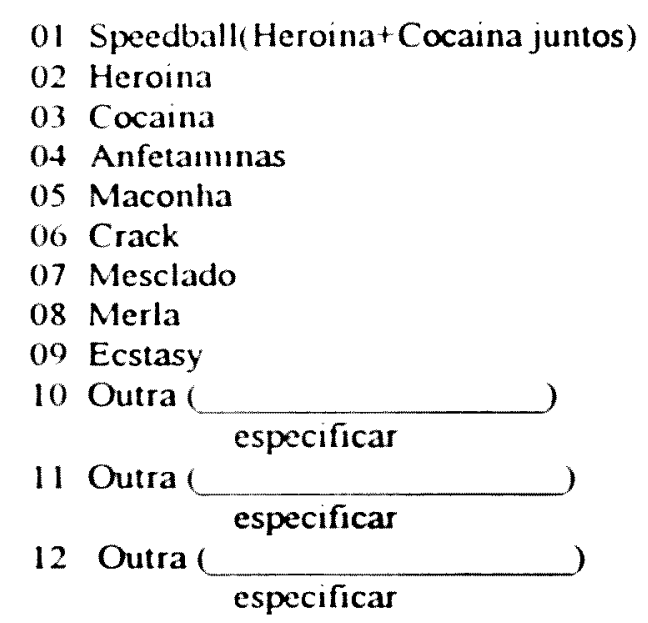

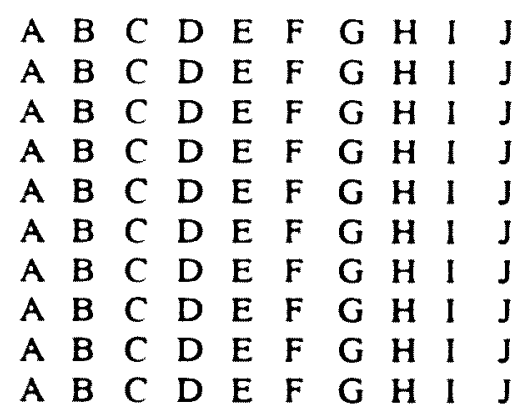

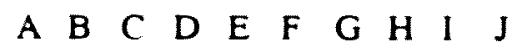

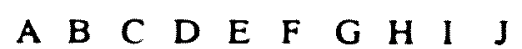

QDo1- Você tem familiares ou amigos que usam drogas injetáveis atualmente?
0 Não
$1 \mathrm{Sim}$
7 Não Aplicavel (nem amigos ou familiares)
8 Recusou-se a responder

QD62- Quantos anos você tinha quando injetou drogas pela última vez?

$$
\text { QE26 }
$$

Pular para QE 26 


\section{SEÇÃO E: COMPORTAMENTOS DE INJEÇÃO E COMPARTILHAMENTO}

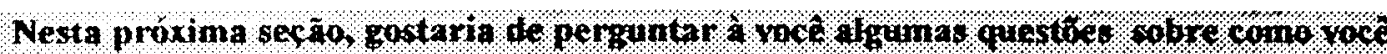

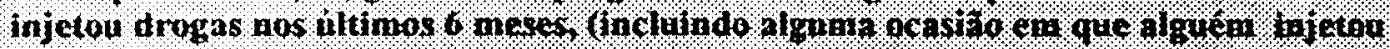

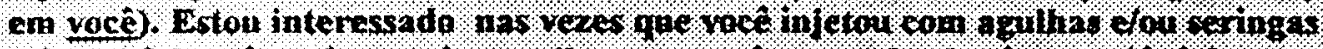

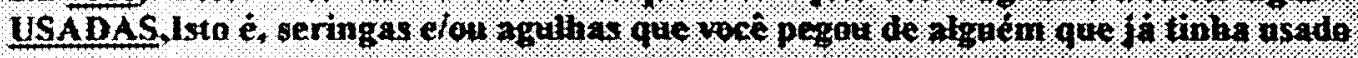
antes.

QE01- Quando vocé injetou nos últimos 6 meses, quantas vezes você fez com agulhas e/ou seringas usadas dadas emprestadas alugadas ou vendidas a você por alguém? (incluindo seu companheiro).

\section{MOSTRAR O CARTÃOA}
A- Nunca $\rightarrow$ QE 07
B- Menos de 1 vez por mês
C $-1-3$ vezes por mês
D- 1 vez por semana
E - 2-3 por semana
F- 4-6 por semana
G. Quase 1 vez por dia
H- 2 - 3 vezes por dia, quase todos os dias
1- 4 ou mais vezes ao dia, quase todos os dias
J- Recusou-se a responder

QE02- Nas vezes que você injetou usando agulhas e/ou seringas usadas, nos últimos 6 meses, quantas vezes eles vieram de.

( Ler cada categoria. Circule um resposta para cada)

\section{MOSTRARO CARTÃOC}

1 Nunca $(0 \%)$

2 Ocasionalmente (1-25\%)

3 Metade das vezes (26-74\%)

4 Na maior parte $(75-99 \%)$

1- Companheiro sexual principal

5 Sempre $(100 \%)$

8 Recusou-se a responder

2- Un parente que não é seu companheiro sexual principal

Quantas Vezes

3- Amigo próximo

$\begin{array}{llllll}1 & 2 & 3 & 4 & 5 & 8\end{array}$

4- Traficante/operador de galeria/ "hit doctor" , isto é uma pessoa que você paga em dinheiro, drogas ou outra forma de serviço para ajuda-lo a se injetar

5- Alguém que você não conhece bem?

$\begin{array}{llllll}1 & 2 & 3 & 4 & 5 & 8\end{array}$

$\begin{array}{llllll}1 & 2 & 3 & 4 & 5 & 8\end{array}$

$\begin{array}{llllll}1 & 2 & 3 & 4 & 5 & 8\end{array}$

$\begin{array}{llllll}1 & 2 & 3 & 4 & 5 & 8\end{array}$

QE03- De quantas pessoas diferentes, no total, você recebeu agulhas e/ou seringas usadas nos últimos 6 meses?

QE04- Nos últimos 6 meses, quando você usou agulhas e/ou seringas dadas, emprestadas, alugadas ou vendidas para você por alguém, quantas vezes você as limpou antes de usar?

\section{MOSTRIRO CARTATOC}

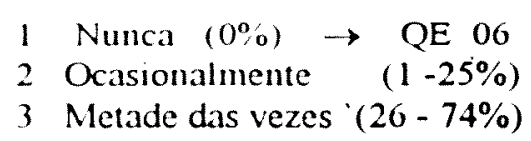

$\begin{array}{ll}4 & \text { Na maior parte }(75-99 \%) \\ 5 & \text { Sempre }(100 \%) \\ 8 & \text { Recusou-se a responder }\end{array}$ 
QE05- Nos últimos 6 meses, como habitualmente você limpou agulhas e/ou seringas que alguém usou?

(Não leia as opçòes. Circule uma resposta)

$\begin{array}{rr}\begin{array}{r}\text { Água } \\ \text { Água fervendo }\end{array} & 01 \\ \text { Sabão ou detergente } & 02 \\ \text { (Hipoclorito de Sódio) Cloro } & 03 \\ \text { Álcool } & 04 \\ \text { Recusou-se a responder/ } & 05 \\ \text { especificar } & 98\end{array}$

QE06- Agora, vou ler uma lista de razões das quais você deve ter compartilhado agulhas e/ou seringas nos últimos 6 meses. Algumas razões servem para você?

(Leia cada item. Circule uma resposta para cada)

1 Outros injetadores me pressionaram para compartilhar

Não Sim Recusa

2 Achei que estava seguro porque as limpei antes

3 Sou cuidadoso com quem compartilho

4 Eu estava preso

5 Nunca tinha minha propria seringa e/ou agulha

6 Agulhas e/ou seringas são dificeis de conseguir

7 Agulhas e/ou seringas são caras

8 Outro ) especificar

9 Outro ( especificar

$\begin{array}{lll}0 & 1 & 8 \\ 0 & 1 & 8 \\ 0 & 1 & 8 \\ 0 & 1 & 8 \\ 0 & 1 & 8 \\ 0 & 1 & 8 \\ 0 & 1 & 8 \\ 0 & 1 & 8 \\ 0 & 1 & 8\end{array}$

QE07- Nos últimos 6 meses, alguma vez você se injetou com uma seringa já cheia de droga?

$\begin{array}{rr}\text { Não } & 0 \\ \text { Sim } & 1 \\ \text { Recusou-se a responder } & 8\end{array}$

QE08- Nos últimos 6 meses, alguma vez você injetou drogas usando uma seringa na qual alguém esguichou dentro droga de outra seringa, já usada por ele (pela frente ou por tras)

$$
\begin{array}{ll}
\text { Não } & 0 \\
\text { Sim } 1
\end{array}
$$

Recusou-se a responder 8

QE09- Nos últimos 6 meses, alguma vez você compartilhou recipiente/frasco pequeno/colher, algodão/filtro, ou água para enxaguar, quando você injetou drogas?

$$
\begin{array}{rr}
\text { Não } & 0 \\
\text { Sim } & 1 \\
\text { Recusou-se a responder } & 8
\end{array}
$$

QEI0- Nos ultimos 6 meses, alguma vez você puxou sua solução de droga de um recipiente comum, compartilhado com outros?

$$
\begin{array}{rr}
\text { Não } & 0 \\
\text { Sim } & 1 \\
\text { Recusou-se a responder } & 8
\end{array}
$$


QE12- Nos últimos 6 meses você injetou dentro de uma "galeria de pico", ponto de tráfico ou outro lugar de uso de drogas?

$$
\begin{array}{rr}
\text { Não } & 0 \\
\text { Sim } & 1 \\
\text { Recusou-se a responder } & 8
\end{array}
$$

QE 13- Nos últimos 6 meses, alguma vez você injetou do lado de fora de uma "galeria de pico", ou outro lugar de uso de drogas?

$$
\begin{array}{rr}
\text { Não } & 0 \\
\text { Sim } & 1 \\
\text { Recusou-se a responder } & 8
\end{array}
$$

QE14- Nos últimos 6 meses, alguma vez você recebeu injeção de um "hit doctor", isto é uma pessoa que você paga em dinheiro, drogas ou outra forma ou serviço para ajudá-lo a se injetar?

$$
\begin{array}{rr}
\text { Não } & 0 \\
\text { Sim } & 1 \\
\text { Recusou-se a responder } & 8
\end{array}
$$

QE15- Nos últimos 6 meses, alguma vez você se injetou usando uma seringa "feita em casa".

Não 0

Sim 1

Recusou-se a responder 8

Agora vou perguntar-lhe sobre a frequência que você tem dado, emprestado, alugado ou vendido suas agulhas e/ou seringas para alguém (não incluir quando alguém injetou em você)

QE16- Quando você injetou nos últimos 6 meses, qual a frequência que você deu, emprestou, alugou ou vendeu para alguém agulha e/ou seringa que você já tinha usado?

\section{MOSTRAR O CARTÃO A}
A- Nunca / Nenhum $\rightarrow$ QE 19
B- Menos de 1 vez por mês
C- $1-3$ vezes por mês
D- 1 vez por semana
E - 2-3 por semana

F- 46 por semana

G- Quase 1 vez por dia

H- $2-3$ vezes por dia, quase todos os dias

I- 4 ou mais vezes ao dia, quase todos os dias

J- Recusou-se a responder

QE17- A quantas pessoas diferentes no total você deu, emprestou, alugou ou vendeu agulhas e/ou seringas usadas, nos últimos 6 meses?

QE18- As vezes que você deu, emprestou, alugou ou vendeu para alguém agulhas e/ou seringas usadas nos últimos 6 meses, alguma vez você deu para...

(Leia cada categoria. Circule uma resposta para cada)

1- Parceiro sexual principal

2- Parente que não é o parceiro sexual principal

3- Amigo intimo

4- Cliente que exerce as funções de "hit doctor"

5- Novo injetador - foi a primeira vez que injetaram

6- Alguém que você não conhece bem?

$\begin{array}{ccc}\text { Não } & \text { Sim } & \text { Rec } \\ 0 & 1 & \mathbf{8} \\ 0 & 1 & 8 \\ 0 & 1 & 8 \\ 0 & 1 & 8 \\ 0 & 1 & 8 \\ 0 & 1 & 8\end{array}$


QE19- Nos últimos 6 meses, você ajudou alguém a se injetar pela primeira vez? (Não leia as opções. Circule uma resposta)

Não $0 \rightarrow$ QE22

Sim 1

Recusou-se a responder $8 \rightarrow$ QE22

Não sabe/Não tem certeza $9 \rightarrow$ QE22

QE20- Nos últimos 6 meses, quantas pessoas diferentes você ajudou a se injetar pela primeira vez?

XE21- Eram algumas dessas pessoas:

(Leia cada categoria. Circule uma resposta para cada)

1- Principal parceiro sexual?

2- Algum parceiro sexual?

3- Seu filho ou filha?

4- Outro parente, mas não parceiro sexual?

5- Conhecido/amigo

6- Pouco conhecido?

$\begin{array}{ccc}\text { Não } & \text { Sim } & \text { Roc. } \\ 0 & 1 & 8 \\ 0 & 1 & 8 \\ 0 & 1 & 8 \\ 0 & 1 & 8 \\ 0 & 1 & 8 \\ 0 & 1 & 8\end{array}$

Agora gostaria de perguntar à você sobre a qualidade de seu uso de agulhas e/ou seringas, isto é, agulhas e/ou seringas nunca usadas antes por ninguém, mesmo você próprio.

QE22- Nos últimos 6 meses, você pegou alguma agulha e/ou seringa nova e não usada?

$$
\begin{aligned}
\text { Não } 0 & \rightarrow \mathrm{XE25} \\
\text { Sim } 1 & \\
\text { Recusou-se a responder } 8 & \rightarrow \mathrm{XE25}
\end{aligned}
$$

QE23- Nos últimos 6 meses, como você conseguiu agulhas e/ou seringas novas e, não utilizadas? (Não leia a lista. Circule mais que um "SIM", se mencionada. Estimule com "algo mais"?)

01- Farmácias

02- Outra loja

03- Máquina que funciona por introdução de moedas

04- Vendedor de rua ou local de venda

05- Médico de familia/profissional geral

06- Hospital

07- Local ou pessoa de tratamento de droga

08- Redutor de danos

09- Local ou pessoa de Centro de Saúde, Policlinica, UBS etc.

10- Parceiro sexual

11- Membro da familia, não parceiro sexual

12- Amigos

13- Outros usuários de droga

14- Traficante

15- Programa de troca de agulha/seringa

16- Roubo de locais que vendem/distribuem

17- Compra nas ruas

23- Outro ( especificar

\begin{tabular}{|c|c|}
\hline \multicolumn{2}{|c|}{ Mencionado } \\
\hline Não & Sim \\
\hline 0 & 1 \\
\hline 0 & 1 \\
\hline 0 & 1 \\
\hline 0 & 1 \\
\hline 0 & 1 \\
\hline 0 & 1 \\
\hline 0 & 1 \\
\hline 0 & 1 \\
\hline 0 & 1 \\
\hline 0 & 1 \\
\hline 0 & 1 \\
\hline 0 & 1 \\
\hline 0 & 1 \\
\hline 0 & 1 \\
\hline 0 & 1 \\
\hline 0 & 1 \\
\hline 0 & 1 \\
\hline 0 & 1 \\
\hline 0 & 1 \\
\hline
\end{tabular}

24- Outro especificar 
( Se mencionado mais de uma forma em $Q E 23$ )

QE24- Qual forma você usa mais frequentemente?

(Use código QE 23)

XE25- Nos últimos 6 meses, policiais ou alguma outra autoridade confiscou de você algum equipamento de injeção?

$\begin{array}{rr}\text { Não } & 0 \\ \text { Sim } & 1 \\ \text { Recusou-se a responder } & 8\end{array}$

QE26- Em sua vida, você já injetou com alguma das seguintes pessoas?

(Leia cada item. Circule uma resposta para cada)

1- Alguém que foi infectado com HIV?

2- Alguém que teve hepatite?

Não Sim Rec

3- Homem usuário de droga injetável que teve sexo com homem?

4- Mulher usuária de droga injetável que teve sexo com mulher?

$\begin{array}{lll}0 & 1 & 8 \\ 0 & 1 & 8 \\ 0 & 1 & 8 \\ 0 & 1 & 8\end{array}$




\section{SEÇÃO G: FUNÇÃO DA DROGA}

(MÓDULO DE OPÇÃO LOCAL)

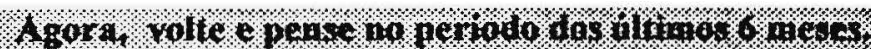

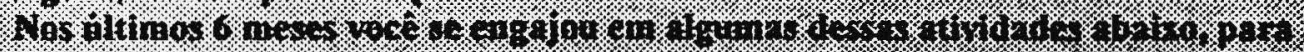

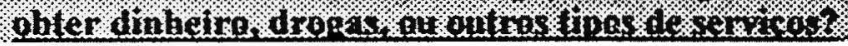

XG01- Você vendeu drogas, ou fez parte de alguma operação de venda de drogas, em troca de dinheiro, drogas ou outros tipos de serviços?

$$
\begin{array}{rr}
\text { Não } & 0 \\
\text { Sim } & 1 \\
\text { Recusou-se a responder } & 8
\end{array}
$$

XG02- Você vendeu agulhas e/ou seringas, em troca de dinheiro, drogas ou outros tipos de serviços?

$\begin{array}{rr}\text { Não } & 0 \\ \text { Sim } & 1 \\ \text { Recusou-se a responder } & 8\end{array}$

XG03- Você já foi pago em dinheiro, drogas ou outros tipos de serviços, por pessoas para ajudálas a injetar drogas ("hit doctor")?

$\begin{array}{rr}\text { Não } & 0 \\ \text { Sim } & 1 \\ \text { Recusou-se a responder } & 8\end{array}$

XG04- Você já possuiu ou operou um lugar, onde as pessoas poderiam injetar drogas, em troca de dinheiro, drogas ou outros serviços?

$\begin{array}{rr}\text { Não } & 0 \\ \text { Sim } & 1 \\ \text { Recusou-se a responder } & 8\end{array}$

XG05- Você jả permitiu que "comerciantes" do sexo trouxessem clientes para um quarto, carro ou espaço que você controlasse, em troca por dinheiro, drogas ou outros serviços?

$\begin{array}{rr}\text { Não } & 0 \\ \text { Sim } & 1 \\ \text { Recusou-se a responder } & 8\end{array}$

XG06- Você já forneceu clientes para um homem ou mulher que vende sexo em troca por dinheiro, drogas ou outros serviços?

$\begin{array}{rr}\text { Não } & 0 \\ \text { Sim } & 1 \\ \text { Recusou-se a responder } & 8\end{array}$

XG07- Você já serviu de guarda para um comerciante do sexo (para avisar quando a policia estiver chegando) em troca de dinheiro, drogas ou outros serviços?

Não 0

Sim 1

Recusou-se a responder 8 
XG08- Você já forneceu proteção física a um homem ou mulher que vende sexo (agindo como um segurança), em troca de dinheiro, drogas ou outros serviços?

Não 0

Sim 1

Recusou-se a responder 8 


\section{SEÇÃO H: COMPORTAMENTO SEXUAL}

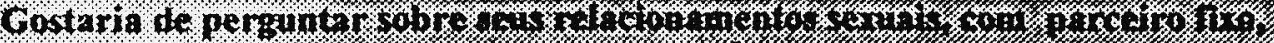

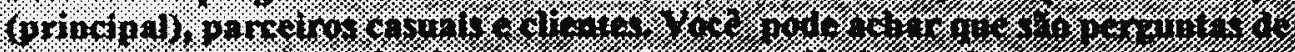

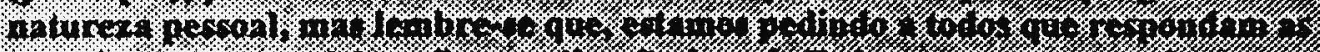

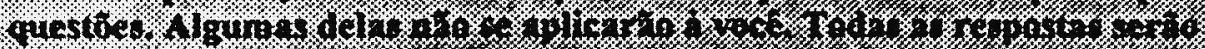

confidenclaits

QH01- Com que frequência você tem relações sexuais (vaginal, anal ou oral) com alguém do sexo oposto, nos últimos 6 meses?

\section{MOSTRAR O CARTÃO A}
A- Nunca / nenhum
$\mathrm{M} \rightarrow \mathrm{QH} 21$
$\mathrm{F} \rightarrow \mathrm{QH} 24$
B- Menos de 1 vez por mês
C- $1-3$ vezes por mês
D- 1 vez por semana
E - 2-3 por semana
F- 4-6 por semana
G- Quase 1 vez por dia
$\mathrm{H}-2-3$ vezes por dia, quase todos os dias
I- 4 ou mais vezes ao dia, quase todos os dias
J- Recusou-se a responder

As próximas questões são sobre sexo com seu parceiro fixo (principal) do sexo oposto. Aplica-se a pessoa mais importante e regular do sexo oposto.

QH02- Nos últimos 6 meses, com que frequência você teve relações sexuais vaginal ou anal com seu parceiro fixo do sexo oposto?

\section{MOSTRAR O CARTÃOA}
A- Nunca/ nenhum $\rightarrow$ QH 08
F- 4-6 por semana
B- Menos de 1 vez por mês
G- Quase 1 vez por dia
C- $1-3$ vezes por mês
H- $2-3$ vezes por dia, quase todos os dias
D- 1 vez por semana
1- 4 ou mais vezes ao dia, quase todos os dias
E - 2-3 por semana
J- Recusou-se a responder

QH03- Com quantos parceiros sexuais fixos do sexo oposto, você teve relações sexuais (vaginal ou anal), nos últimos 6 meses?

QH04- Nos últimos 6 meses, quando você teve relações sexuais(vaginal ou anal) com seu parceiro sexual fixo e do sexo oposto, com que frequência você ou seu parceiro usavam camisinha masculina ou camisinha feminina?

\section{MOSTRAR O CARTÃO C}
1 Nunca $(0 \% 0)$
2 Ocasionalmente (1-25\%)
3 Metade das vezes $(26-74 \%)$
$4 \mathrm{Na}$ maior parte (75-99\%)
5 Sempre $(100 \%)$
8 Recusa-se a responder

QH05- Quantos desses parceiros fixos jả injetaram drogas?

XH06- Até onde você sabe, alguns desses parceiros sexuais fixos já...

(Leia cada item. Circule uma resposta para cada)

1 Falaram que eram HIV positivo ou tinham o virus da AIDS?

2 Foi diagnosticado com hepatite?

3 Fez sexo com (outros) homens?

$\begin{array}{ccc}\text { Não } & \text { Sim } & \text { Rec. } \\ 0 & 1 & 8 \\ 0 & 1 & 8 \\ 0 & 1 & 8\end{array}$


QH07- Nos últimos 6 meses, quais métodos de contraconcepção você e seu parceiro fixo usaram? (Não leia a lista. Circule mais de um "sim", se mencionado. Estimule somente com "mais algum"?)

01 Nenhum

02 Camisinhas

03 Camisinha femunina

04 Pilula Anticoncepcional

05 Injeção Anticoncepcional

06 DIU

07 Diafragma/Cap

08 Espermicida ou "esponja"

09 Metodo da Tabelinha

10 Esterilização

16 Outro ) especificar

17 Outro ( especificar

$\begin{array}{cc}\text { Não } & \text { Sim } \\ 0 & 1 \\ 0 & 1 \\ 0 & 1 \\ 0 & 1 \\ 0 & 1 \\ 0 & 1 \\ 0 & 1 \\ 0 & 1 \\ 0 & 1 \\ 0 & 1 \\ 0 & 1 \\ 0 & 1\end{array}$

As próximas perguntas são sobre relacōes sexuais con parceiros casuais do sexo oposto. Pnrceivo casual, aplica-se a relaçóes tidas con outros, além do parceiro fixa. Nâo incluir "clientes pagos" nas respostas sobre parceiros casuais.

QH08- Com que frequência você teve relaçòes sexuais (vaginal ou com parceiros casuais do sexo oposto? ANAL

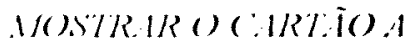
A- Nunca/Nenhum $\rightarrow$ QH 13
B- Menos de 1 vez por més
C- $1-3$ vezes por mês
D- 1 vez por semana
E - 2-3 por semana
F- 4-6 por semana
G- Quase I vez por dia
H- $2-3$ vezes por dia, quase todos os dias
I- 4 ou mais vezes ao dia, quase todos os dias
J- Recusou-se a responder

QH09- Com quantos parceiros sexuais casuais do sexo oposto você teve relaçòes sexuais(vaginal ou anal), nos ultimos 6 meses?

QHıO- Nos últımos 6 meses, quando você tınha relaçōes sexuais (vaginal ou anal) com seus parceiros sexuais casuais, com que frequência vocè ou seu parceiro usaram camisinha ou camismha femmma?
MOSTRHRO(ARTIO)
1 Nunca $(0 \% 0)$
2 Ocasionalmente $(1-25 \%)$
3 Metade das vezes $(26-74 \%)$
$4 \mathrm{Na}$ maior parte $(75-99 \%)$
5 Sempre $(100 \%)$
8 Recusa-se a responder

QH11- Quantos desses parceiros casuais jả injetaram drogas?

XH12- Até onde vocè sabe, alguns desses parceiros casuais já...

(Leia cada item. Circule uma resposta para cada)

I Falaram que eram HIV positivo ou tinham o virus da AIDS?

2 Foi diagnosticado com hepatite?

3 Fez sexo com (outros) homens?

$\begin{array}{ccc}\text { Não } & \text { Sim } & \text { Rec } \\ 0 & 1 & 8 \\ 0 & 1 & 8 \\ 0 & 1 & 8\end{array}$


As próxinas perguntas serão sobre atividades sexuais con clientes do sexo oposto. Aplica-se a pessons que deram dinheiro, drogas on autros servicos a você em traca de sexo. Quando ne refíro a relacōes sexuais signifıca relacōes (vaginal, anal, ornl e masturbação).

QH13- Nos ultmos 6 meses, com que frequéncia vocé teve cliente, que deu dinheiro ou bens à vocé ell troca de sexo?

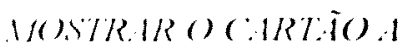
A- Nunca/Nenhum
B- Menos de I vez por senas m
C. $1-3$ vezes por mês
D- I vez por semana
E - 2-3 por semana

\author{
F- 4-6 por semana \\ G- Quase 1 vez por dia \\ $\mathrm{H}-2$ - 3 vezes por dia, quase todos os dias \\ 1- 4 ou mais vezes ao dia, quase todos os dias \\ J- Recusou-se a responder
}

QH14- Nos ultumos o meses, com que frequència você teve cliente, que deu drogas à vocé ell troca de sexo?

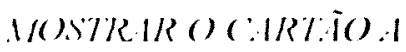
A- Nunca/Nenhum
B- Menos de I vez por

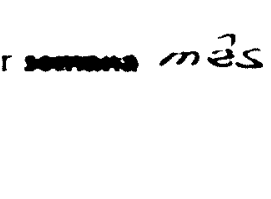
$C-1-3$ vezes por més
D- I vez por semana
E - 2-3 por semana

F- 4-6 por semana

G- Quase 1 vez por dia

H- 2 - 3 vezes por dia, quase todos os dias

1- + ou mais vezes ao dia, quase todos os dias

J- Recusou-se a responder

(Se "nunca"em ambas $Q H 1.3$ e $Q H 14 \rightarrow X H 18$ ou $Q H 21)$.

(Não pergunte se a resposta para $Q H 13$ e $Q H$ I 4 foi nunca)

QHI5- Nos ultimos 6 meses, quantos clientes diferentes você teve. em 1 mês?

(Fazer a melhor estımatıva. Se "são muitos para contar",cod."995").

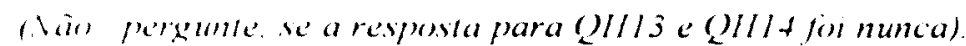

Gostara de suber sobre todos os clientes que vocè teve nos últimos

sers meres

PHlo- Qual a frequéncıa do uso de camisinhas ou camisinhas femininas, quando houve relações sexuars (vaginal ou anal) com clientes?

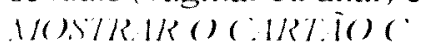
I Nunca $\left.(0)^{0}, 0\right)$
2 Ocasionalmente $(1-25 \%)$
$4 \mathrm{Na}$ maior parte $(75-99 \%)$
3 Metade das vezes $(26-74 \%)$
5 Sempre $(100 \%)$
8 Recusa-se a responder

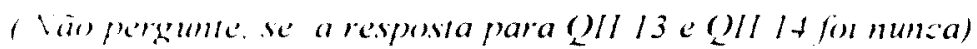

QH17- Nos ultimos seis meses, qual a frequência de sexo oral que você teve com clientes?

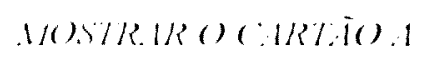
A- Nunca/Nenhum
B- Menos de I vez por
C- 1 - 3 vezes por mès
D- 1 vez por semana
E - 2-3 por semana
F- 4-6 por semana
G- Quase 1 vez por dia
$\mathrm{H}-2$ - 3 vezes por dia, quase todos os dias
1- 4 ou mais vezes ao dia, quase todos os dias
J- Recusou-se a responder


XH18- Nos últimos seis meses, você deu dinheiro ou bens para ter sexo com alguém do sexo oposto?

$$
\begin{array}{rr}
\text { Não } & 0 \\
\text { Sim } & 1 \\
\text { Recusou-se a responder } & 8
\end{array}
$$

XH19- Nos últimos seis meses, você deu drogas para ter sexo com alguém do sexo oposto?

$$
\begin{array}{rr}
\text { Não } & 0 \\
\text { Sim } & 1 \\
\text { Recusou-se a responder } & 8
\end{array}
$$

(Se "não" ou " recusou-se a responder" para ambos $\mathrm{XH} 18$ e XH19 $\rightarrow$ QH21). Se o entrevistado for homem perguntar $Q H 21$ a $Q H 23$

Se o entrevistado for mulher perguntar $\mathrm{QH} 24$ a $\mathrm{QH} 26 \rightarrow \mathrm{QH} 24$

Pergunte somente se a resposta foi "sim" para XHI8 ou XH19.

- Agora, pense sobre lodas as vezes. Nos últimos seis meses em que você deu dinheiro, bens ou drogas para ter sexo com alguém do sexo oposto.

XH20- Qual a frequência do uso de canisinha, ou camisinhas femininas, quando houve relações sexuais (vaginal ou anal) com esses parceiros?

\section{MOSTRAR O CARTÃO C}
1 Nunca $(0 \% 0)$
2 Ocasionalmente (1-25\%)
$4 \mathrm{Na}$ maior parte $(75-99 \%)$
3 Metade das vezes $(26-74 \%)$
5 Sempre (100\%)
8 Recusa-se a responder

('Pergumte somente para o entrevistado do sexo masculino)

QH21 - Nos últimos 5 anos, em qualquer ocasião, você teve relações sexuais anal e/ou oral) com outro homem (incluindo: prisão cu por dinheiro, voluntariamente ou não)?
o Não
$\rightarrow \quad \mathrm{XH} 27$
1 Sim
$\rightarrow \quad \mathrm{XH} 27$
(l'ergunte somente para o entrevistado do sexo masculino).

$\mathrm{QH} 22$ - Conn quantos parceiros homens você teve sexo (anal e ou oral) nos últimos 6 meses.

$$
\overline{\mathrm{Se} “ 00 "} \overline{\mathrm{XH} 27}
$$

(Pengunte somente para o entrevistado do sexo masculino)

QH23- Com que frequência você usou camisinha, quando fez sexo com outro homem, nos últimos 6 meses.

\section{MOSTRAR O CARTÃO C}
1 Nunca $(0 \% 0)$
2 Ocasionalmente (1-25\%)
$4 \mathrm{Na}$ maior parte (75-99\%)
3 Metade das vezes (26-74\%)
5 Sempre (100\%)
8 Recusa-se a responder

Pular para $\mathrm{XH27}$ 
(Pergumtar (somente para entrevistado do sexo feminino)

QH24- Nos últimos 5 anos, em qualquer ocasião, você teve relações sexuais (incluindo: em prisão ou por dillheiro, voluntariamente ou não) com outra mulher?
O Não $\rightarrow \quad \mathrm{XH} 27$
I Sim
8 Sem resposta $\rightarrow \mathrm{XH} 27$
('elguntar somente para o entrevistado do sexo feminino)

QH25- Com quantos parceiros mulheres você teve sexo nos últimos 6 meses?

$$
\text { se "00" } \rightarrow \overline{\mathrm{XH27}}
$$

(Perguntar somente para entrevistados do sexo feminino)

QH26- Com que frequência você usou camisinha feminina (ou protetor para sexo oral) quando fez sexo com outra mulher, nos últimos 6 meses?

\section{MOSTRAR O CARTÃO C}
1 Nunca $(0 \% 0)$
$4 \mathrm{Na}$ maior parte $(75-99 \%)$
2 Ocasionalmente (1-25\%)
5 Sempre (100\%)
3 Metade das vezes $(26-74 \%)$
8 Recusa-se a responder

(Para não injetadores, omitir Seção I, e pular para Seção J)

$\mathrm{XH} 27$ - Você acha que o uso de álcool altera sua determinação de usar camisinha com seus(as) parceiros(as)?
Não 0
Sim 1
Recusou-se a responder 8
N.70 AR/CÁVGL 7

XH28- Você acha que o uso de droga altera sua determinação de usar camisinha com seus (as) parceiros(as)?

$$
\begin{array}{ll}
\text { Não } 0 & \rightarrow \text { Sec. } 1 \text { ou J } \\
\text { Sim } 1 & \\
\text { Recusou-se a responder } 8 & \rightarrow \text { Sec. } 1 \text { ou J } \\
\text { N.̃̃ APLICAVEL } 7 &
\end{array}
$$

XH29- Que drogas alteram esta disposição?
Maconha
Cocaina
Crack
Outros especificar

Para "não injetadores, omitir Seção I, e pular para Seção J 


\section{SEÇÃO I: VIAGEM}

(Perguntar esta seção somente para injetores ou ex-injetores)

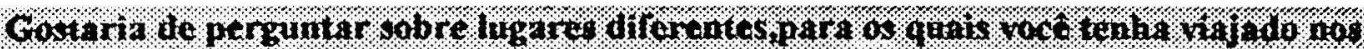

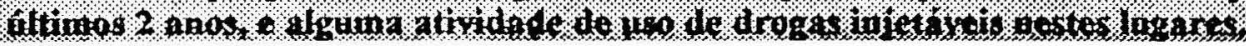

Q101- Você injetou drogas fora da cidade, onde você mora nos últimos 2 anos?

$$
\begin{array}{r}
\text { Não } 0 \rightarrow \text { Sec. J } \\
\text { Sim } 1 \\
\text { Recusou-se a responder } 8 \rightarrow \text { Sec. J }
\end{array}
$$

Q102- Em alguns desses lugares, você injetou drogas com agulhas ou seringas dadas, emprestadas, alugadas ou vendidas para você por pessoas que você conheceu nesses lugares?

$$
\begin{array}{rr}
\text { Não } & 0 \\
\text { Sim } & 1 \\
\text { Recusou-se a responder } & 8
\end{array}
$$

QI04- Nesses lugares você injetou drogas usando uma seringa depois que alguém que você conheceu lá, esguichou drogas dentro da seringa (pela frente ou por traz)?

$$
\begin{array}{rr}
\text { Não } & 0 \\
\text { Sim } & 1 \\
\text { Recusou-se a responder } & 8
\end{array}
$$

Q105- Nesses lugares, você compartilhou: colher, algodão, água para lavar, ou algum outro utensilio de injeção, com pessoas que você conheceu lá?

$\begin{array}{rr}\text { Não } & 0 \\ \text { Sim } & 1 \\ \text { Recusou-se a responder } & 8\end{array}$

Q106- Nesses lugares, você puxou droga de uma solução comum compartilhado por outras pessoas que você conheceu lá.

$\begin{array}{rr}\text { Não } & 0 \\ \text { Sim } & 1 \\ \text { Recusou-se a responder } & 8\end{array}$

Q107- Você fez sexo com alguém que tinha conhecido nesses lugares?

$\begin{array}{rr}\text { Não } & 0 \\ \text { Sim } & 1 \\ \text { Recusou-se a responder } & 8\end{array}$

QI08- Usou camisinha sempre nestas relações?

$\begin{array}{rr}\text { Não } & 0 \\ \text { Sim } & 1 \\ \text { Recusou-se a responder } & 8\end{array}$




\section{SEÇÃO J: CONHECIMENTO SOBRE AIDS E MUDANÇA DE COMPORTAMENTO}

\section{Gostaria de perguntar sobre HIV e AIDS}

QJ01- Alguma vez já ouviu falä sobre HIV e AIDS?
0 Não
$\rightarrow$ Sec. K
$1 \mathrm{Sim}$
8 Recusou-se a responder $\rightarrow$ Sec $\mathrm{K}$

QJ02- Com que frequência você fala sobre HIV ou AIDS, com seu parceiro sexual?

(Leia as questões - exceto recusa. Circule uma resposta)
0 Nunca
1 Raramente
2 Frequentemente
7 Não aplicável (sem parceiro sexual)
8 Recusou-se a responder

QJ03- Com que frequência você fala sobre HIV ou AIDS com seus amigos usuários de drogas? (Leia as questōes -- exceto recusa. Circule uma resposta)
0 Nunca
1 Raramente
2 Frequentemente
7 Não aplicável (sem amigos usuários de drogas)
8 Recusou-se a responder

QJ04- Com que frequência você fala sobre HIV ou AIDS, com membros da sua familia?

(Leia as opçöes - exceto recusa. Circule uma resposta).
0 Nunca
1 Raramente
2 Frequentemente
7 Não aplicável (Sem farailia)
8 Recusou-se a responder

QJ05- Você acha que uma pessoa infectada com HIV (o virus que causa (AIDS), pode apresentar um aspecto saudável?
0 Não
1 Sim
8 Recusou-se a responder
9 Não sabe 
QJ06- Você pode me dizer as maneiras corno as pessoas podem ser infectadas com HIV? (Não leia a lista. Circule mais de um "sim" se mencionado. Estimule com "algo mais").

01 Não sabe nenhuma maneira

02 Compartilhando agulhas e/ou seringas

03 Compartilhando outro equipamento para injeção/solução de droga

Mencionado

04 Praticando sexo (sem proteção especificada)

05 Praticando sexo sem proteção (camisinha)

06 Contato com sangue infectado

07 Transfusão de sangue/derivados de sangue

Não Sim

08 Perinatal, de mãe para filho

09 Outro

10 Outro ) especificar especificar

QJ07- Do número de pessoas que se contaminam com HIV, quantos você pensa que vão ficar doentes, com AIDS?

MOSTRAR O CARTÃO B
1 Nenhum (a) $10 \%$ )
4 Maioria (75-99\%)
2 Um pouco (1-25\%)
3 Metade $(26-74 \%)$
5 Tudo / Todo $(100 \%)$

QJ08- Desde a primeira vez em que você ouviu sobre HIV/AIDS, você fez alguma coisa para evitar pegar o virus ou evitar que alguém pegasse de você?
0 Não
$\rightarrow$ Sec. K
1 Sim
$\rightarrow \quad$ Sec. $K$ 
QJ09- O que você tem feito?

(Nâo leia a lista. Circule mais de um "sim" se mencionado. Pergunte somente "algo mais").

\section{$\underline{\mathrm{SEXO}}$}

01 Começou/aumentou o uso de camisinha

02 Outra prática de sexo seguro (não especificado)

03 Diminui o numero de parceiros sexuais

04 Diminui gays masculino/parceiros bissexuais

05 Menor numero de parceiros injetores de drogas

06 Parou de fazer sexo

07 Outra mudança de comportamento sexual

08 Outra mudança de comportamento sexual
Mencionado

Não Sim

$0 \quad 1$

0

0

$0 \quad 1$

0

0

$0 \quad 1$

0

1
1
1
1
1
1

\section{DROGAS}

09 Menor uso de drogas em geral

10 Reduziu a injeção de drogas

11 Parou a injeção de drogas

12 Reduziu a divisão utensilios/solução para drogas

13 Parou de dividir utensilios/solução para drogas

14 Começou/aumentou limpeza dos apetrechos

15 Outra mudança de comportamento de drogas

16 Outra mudança de comportamento de drogas (

especificar

especificar

OUTROS

especificar

especificar

17 Outra mudança (

18 Outra mudança especificar

especificar

$\begin{array}{ll}0 & 1 \\ 0 & 1 \\ 0 & 1 \\ 0 & 1 \\ 0 & 1 \\ 0 & 1 \\ 0 & 1 \\ & \end{array}$

XJ10- Você conhece algumas das seguintes pessoas que foram infectadas por HIV ou que tem AIDS?

( leia as opçoôs. Circule uma resposta para cada.N / A (não se aplica) se não houver conhecimento do entrevistado nos itens descritos)

01 Assiduo usuario de drogas, que tenha compartilhado

Não Sim N/A Rec equipamento com você.

02 Outro assiduo usuário de drogas

03 Alguém que tenha sido seu parceiro sexual

04 Alguém que tenha morado com você (em sua casa)

05 Amigos ou parentes

06 Outra pessoa que conheça

$\begin{array}{llll}0 & 1 & 7 & 8 \\ 0 & 1 & 7 & 8 \\ 0 & 1 & 7 & 8 \\ 0 & 1 & 7 & 8 \\ 0 & 1 & 7 & 8 \\ 0 & 1 & 7 & 8\end{array}$




\section{SEÇÃO K: HISTÓRICO MÉdICO}

QK01- Como você descreveria sua saúde arualmente? Você diria que está..

(Leia as opcões - exceto Recusou-se a responder ou não sabe / sem certeza Não Sabe -

Circule uma resposta)
1 Excelente
2 Boa
3 Mais ou menos
4 Fraca
8 Recusou-se a responder
9 Não sabe / sem certeza

QK02-

QK03-

Alguma vez um médico, enfermeira ou outro profissional de saúde, disse à você que tinha ( tipo de infecção).

(eia as opçōes. Circule uma resposta para cada)

(Se "sim")

Quando foi a última vez em que você ouviu que tinha

( tipo de infecção)

\section{QK02 Sempre disse?}

01- Tuberculose (TB)

02- Endocardite (infeç̧ão no coração)

Não Sim Rec. N / sabe

03- Pneumonia (Não PCP)

$\begin{array}{llllll}0 & 1 & 8 & 9 & - \\ 0 & 1 & 8 & 9 & --\end{array}$

(Não Pneumocites

Carine)

04- Cirrose

05- Infecções na boca, como sapinho ou afta, devido a fungos

06- Sifilis

07- Gonorréia

08- Verruga genital

09- Herpes genital

10- Clamidia (uretrite não gonocócica)

11 Hepatite

12 Malária

(Perguntar itens 13-15 somente se o entrevistado

$\mathrm{Se}$ "sim"

QK03 ano for um assiduo ou ex- usuário de droga injetável)

13 Abscesso numa área de injeção

14 Abscesso em outro lugar do corpo

15 Colapso das veias ou outro estrago direto causado pela injeção de drogas

16 Inflamação pélvica

17 Câncer cervical

18 Dengue

$\begin{array}{lllll}0 & 1 & 8 & 9 & --- \\ 0 & 1 & 8 & 9 & - \\ 0 & 1 & 8 & 9 & - \\ 0 & 1 & 8 & 9 & -- \\ 0 & 1 & 8 & 9 & - \\ 0 & 1 & 8 & 9 & -\end{array}$

QK04- Você já fez alguma consulta ou aconselhamento individual a respeito de um teste de HIV?

Nào 0

Sim 1

Recusou-se a responder 
QK05- Você já fez um teste HIV (virus da AIDS)?
0 Não
$\rightarrow$ QK 13
$1 \mathrm{Sim}$
$\begin{array}{ll}8 \text { Recusou-se a responder } & \rightarrow \text { QK } 13 \\ 9 \text { Não sabe } & \rightarrow \text { QK } 13\end{array}$

QK06- Onde você fez o teste?

(Não leia a lista. Circule mais de um "sim" se mencionado. Pergunte somente "algo mais")

01 Centro de Tratamento de Drogas

02 Clinica DST

03 Hospital

04 Médico particular

05 Kit de teste caseiro

06 Prisão

07 COAS

08 Centro de Referência de AIDS ou SAE

09 Direto em laboratório

10 Outro especificar

11 Outro (

$\begin{array}{cc}\text { Mencionado } \\ \text { Não } & \text { Sim } \\ 0 & 1 \\ 0 & 1 \\ 0 & 1 \\ 0 & 1 \\ 0 & 1 \\ 0 & 1 \\ 0 & 1 \\ 0 & 1 \\ 0 & 1 \\ 0 & 1 \\ 0 & 1\end{array}$

QK07- Você pegou o resultado de algum teste de HIV?
0 Não
$\rightarrow$ QK 13
1 Sim
$\rightarrow$ QK 13
8 Recusou-se a responder
$\rightarrow$ QK 13

QK08- Você já pegou algum resultado positivo, indicando que você estava Infectado com HIV?
0 Não
$1 \mathrm{Sim}$
$\rightarrow$ QK 11
8 Recusou-se a responder
$\rightarrow$ QK 11

QK09- Você recebeu aconselhamento pós-teste?
0 Não
1 Sim
8 Recusou-se a responder

QK10- Quando foi a primeira vez que falaram que você era HIV positivo? (mês) (ano)

QK11- Alguma vez você pegou um teste negativo?
0 Não i) $4 \times 13$
$1 \mathrm{Sim}$
8 Recusou-se a responder
$Q K \angle$

QK12- Quando foi a última vez que falaram que você era HIV negativo? (mês) (ano) 
QK13- . iltimos seis meses, você tomou alguma medic:

n: Licamentos do coquetel, ou algum outro?

.si-aids, como AZT, DDA, $c$ 'ros
o Não
$\rightarrow$ QK 15
1 Sim
$2 \mathrm{Sim}$, mas não sei que tipo $\rightarrow$ QK 1
8 Recusou-se a responder $\rightarrow$ QK 1

QK14- Nos últimos seis meses, que tipo de medicação anti-aids você tomou? (Leia cada item. Circule uma resposta para cada)
01 AZT
$02 \mathrm{DDI}$
03 DDC
04 Outros do Coquetel
05 Algum, mas não sei o nom
Ci $i$ i'cos (-

QK15- Alguma vez, um médico, en $\Upsilon$ meira ou outro. ufissional de saúde, disse que você tinha AIDS?
0 Não
$\rightarrow$ Seção L
1 Sim
8 Recusou-se a responder $\rightarrow$ Seção L

QK16- Quando foi a primeira vez que disseram que você tinha AIDS?

$$
\text { (mês) }
$$
(ano) 


\section{SEÇÃO L: HEPATITE}

Agora, wou perguntar a voce sobre ung doenca chanad d, bogafie

QL01- Você poderia me dizer, quais são os diferentes tipos de hepatite? (Não leia a lista. Circule mais de um "sim" se mencionado. Pergunte somente alguma outra)

1 Não sabe o nome de nenhum tipo

2 Hepatite A

3 Hepatite B

4 Hepatite C

5 Hepatite D ou E

6 Outros $($ especificar

$\begin{array}{cc}\text { Não } & \text { Sim } \\ 0 & 1 \\ 0 & 1 \\ 0 & 1 \\ 0 & 1 \\ 0 & 1 \\ 0 & 1\end{array}$

QL02- Você já tomou vacina de Hepatite B?
0 Não
$\rightarrow$ QL 04
1 Sim
3 Recebi vacina de hepatite, mas não sei o tipo
8 Recusou-se a responder
9 Não sabe
$\rightarrow$ QL 04

QL03- Quantas doses você tomou? $\rightarrow$ QL 05

QL04- Se você tivesse a oportunidade de tomar uma vacina contra Hepatite B, você tomaria?
0 Não
$\rightarrow$ Qk 13
1 Sim
$\rightarrow$ QK 13 
Se ontrevistado mencionou Hepatite $B$ e / ou C.na questão QL Ol, pergunte cada questão QL05 até QL20, por vez para Hepatute " $B$ " e ou Hepatite " $C$ " separadamente. Se ele ela näo mencionou B ou C pergunte para "hepatite" e coluna" Hep. N.

QL07-

Como a Hepatite $(B / C)$ e transmitida?

(Não leia as questōes. Circule mais de um "sim"se mencionado. Pergunte"alguma outra forma")?

01 Nào sabe nenhuma forma

02 Compartilhando agulhas/seringas

03 Compartilhando outros equipamentos e solução de injeção

04 Praticando sexo (s/proteção especificada)

05 Praticando sexo sem proteção (camisinha)

06 Em contato com sangue contaminado

$07 \mathrm{Em}$ contato com outros liquidos contaminados do corpo

08 Compartilhando talheres/pratos/copos

09 Compartilhando escova de dente, pente, toallı, barbeador

10 Instrumentos infectados de tatuagens/ piercings

II Transfusão de sangue/produtos e derivados sanguineos

12 Perinatal, de mãe para filho

13 Outro (

14 Outro ) especificar ) especificar

\begin{tabular}{|c|c|c|c|c|c|}
\hline \multirow{4}{*}{\multicolumn{2}{|c|}{$\begin{array}{l}\text { QLOS } \\
\text { Menc. } \\
\text { Hep.B } \\
\tilde{N} . S .\end{array}$}} & \multicolumn{2}{|c|}{ QL06 } & \multicolumn{2}{|c|}{ QL07 } \\
\hline & & & nc. & & tenc. \\
\hline & & & p.C & & ep. $N$ \\
\hline & & & & & $\mathrm{S}$. \\
\hline 0 & 1 & 0 & 1 & 0 & 1 \\
\hline 0 & 1 & 0 & 1 & 0 & 1 \\
\hline 0 & 1 & 0 & 1 & 0 & 1 \\
\hline 0 & 1 & 0 & 1 & 0 & 1 \\
\hline 0 & 1 & 0 & 1 & 0 & 1 \\
\hline 0 & 1 & 0 & 1 & 0 & 1 \\
\hline 0 & 1 & 0 & 1 & 0 & 1 \\
\hline 0 & 1 & 0 & 1 & 0 & 1 \\
\hline 0 & 1 & 0 & 1 & 0 & 1 \\
\hline 0 & 1 & 0 & 1 & 0 & 1 \\
\hline 0 & 1 & 0 & 1 & 0 & 1 \\
\hline 0 & 1 & 0 & 1 & 0 & 1 \\
\hline 0 & 1 & 0 & 1 & 0 & 1 \\
\hline 0 & 1 & 0 & 1 & 0 & 1 \\
\hline
\end{tabular}


XL10-

XL08-

Onde você ouviu falar sobre Hepatite $(B / C)$ ?

(Não leia a lista. Circule mais de um "sim" se mencionado. Pergunte

"algum outro lugar?")

01 Médico/enfermeira/outro Profissional da saúde

$02 \mathrm{Jornal} / \mathrm{revista/rádio} / \mathrm{TV}$

03 Familia/amigos

04 Escola/trabalho

05 Panfletos/cartaz

06 Usuários de Drogas Injetáveis

07 Organização de Usuários de Drogas Injetáveis

08 Redutores de danos (outreach workers)

09 Programa de troca de agulhas/seringas

10 Companheiro de prisão

11 Outro (_ ) especificar

12 Outro (_ ) especificar

13 Nunca ouvi falar

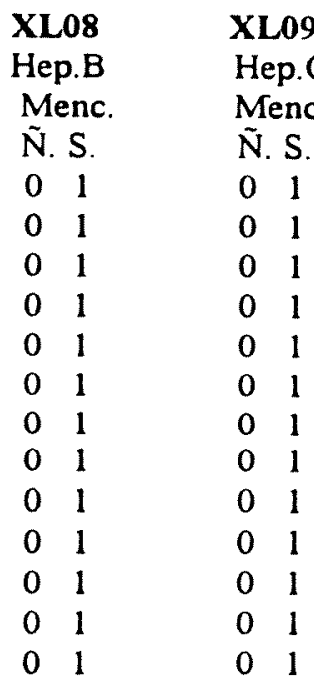

XL10

Hep.N

Menc.

N $\mathrm{S}$

$0 \quad 1$

$\begin{array}{ll}0 & 1\end{array}$

$\begin{array}{ll}0 & 1\end{array}$

c 1

$0 \quad 1$

$0 \quad 1$

$0 \quad 1$

$\begin{array}{ll}0 & 1\end{array}$

$0 \quad 1$

$0 \begin{array}{ll}0 & 1\end{array}$

$0 \quad 1$

$\begin{array}{ll}0 & 1\end{array}$

$\begin{array}{ll}0 & 1\end{array}$

QL11-

QL13-

Você se preocupa em pegar Hepatite $(B / C)$ ?

Você diria que.

(Leia as opções exceto Recusou-se a responder. Circule uma resposta)

QL11 QL12 QL13

Hep.B Hep.C Hep.N

Não se preocupa

Um pouco preocupado

Muito preocupado

$1 \quad 1 \quad 1$

$2 \quad 2 \quad 2$

Já está vacinado/imunizado (aplica-se somente p/Hep.B) 7

Recusou-se a responder

8

$8 \quad 8$

QL14-

QL16-

Qual porcentagem de pessoas que têm Hepatite $(B / C)$ se tornaram seriamente doentes?

MOSTRARO CARTAOOB

$\begin{array}{lrr}\text { QL14 } & \text { QL15 } & \text { QL16 } \\ \text { Hep.B } & \text { Hep.C } & \text { Hep.N }\end{array}$

Nenhum $(0 \%)$

Um pouco $(1-25 \%)$

Metade $(26-74 \%)$

Maioria ( $75-99 \%)$

Tudo / Todo ( $100 \%$ )

Recusou-se a responder

Não sabe

$\begin{array}{lll}1 & 1 & 1 \\ 2 & 2 & 2 \\ 3 & 3 & 3 \\ 4 & 4 & 4 \\ 5 & 5 & 5 \\ 8 & 8 & 8 \\ 9 & 9 & 9\end{array}$


XL17-

XL19-

Você conhece algumas das seguintes pessoas que foram infectadas pela Hepatite $B / C$ ?

(Leia cada item. Circule uma resposta para cada. N/A (não aplicável) deverá ser circulada se o entrevistado não souber nenhuma descrita).

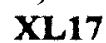

XL18

XL19

Hep. B

Hep.C

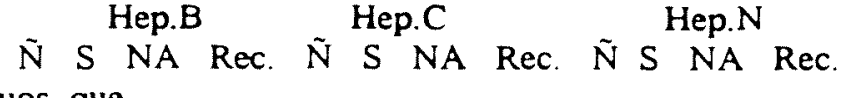

1- Usuários de drogas i njetáveis assiduos, que

compartilharam equipamentos de injeção

comvocê

2- Outros usuários de drogas

injetáveis assiduos

3- Alguém que tenha sido seu

parceiro sexual

4- Alguém que mora com

você (em sua casa)

5- Outros amigos ou parentes

6- Outros

$\begin{array}{llllllllllll}0 & 1 & 7 & 8 & 0 & 1 & 7 & 8 & 0 & 1 & 7 & 8 \\ 0 & 1 & 7 & 8 & 0 & 1 & 7 & 8 & 0 & 1 & 7 & 8 \\ 0 & 1 & 7 & 8 & 0 & 1 & 7 & 8 & 0 & 1 & 7 & 8 \\ 0 & 1 & 7 & 8 & 0 & 1 & 7 & 8 & 0 & 1 & 7 & 8 \\ 0 & 1 & 7 & 8 & 0 & 1 & 7 & 8 & 0 & 1 & 7 & 8 \\ 0 & 1 & 7 & 8 & 0 & 1 & 7 & 8 & 0 & 1 & 7 & 8\end{array}$

QL22-

Você ja conversou sobre Hepatite $\mathrm{B} / \mathrm{C}$ com algumas das seguintes pessoas?

(Leia cada item. Circule uma resposta para cada. N/ A ( Não aplicável) deverá ser circulada se o entrevistado não souber nenhuma descrita).

QL20

QL21

Hep.C

QL22

Hep.B

$\tilde{N}$ S NA Rec. $\tilde{N}$ S NA Rec. N S NA Rec.

Hep.N

1- Usuários de drogas injetáveis assiduos,

que compartilharam equipamentos de

injeção com você
2- Outros usuários de drogas injetávei

assiduos

$\begin{array}{llllllllllll}0 & 1 & 7 & 8 & 0 & 1 & 7 & 8 & 0 & 1 & 7 & 8\end{array}$

assiduos

eis

3- Alguém que tenha sido seu parceiro

sexual

0

4- Alguém que mora com você (em sua

casa)

5- Outros amigos ou parentes

6- Outros

$\begin{array}{llllllllllll}0 & 1 & 7 & 8 & 0 & 1 & 7 & 8 & 0 & 1 & 7 & 8 \\ 0 & 1 & 7 & 8 & 0 & 1 & 7 & 8 & 0 & 1 & 7 & 8 \\ 0 & 1 & 7 & 8 & 0 & 1 & 7 & 8 & 0 & 1 & 7 & 8\end{array}$

Se o entrevistado respondeu a todas as questôes sobre Hepatite $N$, sem distinguir entre os tipos B/C, pular para Seção M $\rightarrow$ Seção M.

QL23- Você já fez teste para Hepatite C?
1 Não
$\rightarrow$ Sec.M
$0 \mathrm{Sim}$
8 Recusou-se a responder $\rightarrow$ Sec.M
9 Não sabe
$\rightarrow$ Sec.M

QL24- Você já pegou algum resultado de teste de Hepatite C?
O Não
$\rightarrow$ Sec. M
$1 \mathrm{Sim}$
$\rightarrow$ Sec. $M$
8 Recusou-se a responder
$\rightarrow$ Sec. $M$
$\rightarrow$ Sec. $M$ 
QL25- Você já pegou algum teste negativo?
0 Não
$\rightarrow$ QL 27
1 Sim
$\rightarrow$ QL 27

XL26- Quando foi a última vez que você pegou um teste negativo de Hepatite C? (mês) (ano)

QL27- Você já pegou um resultado positivo?
0 Não
$\rightarrow$ Sec. M
$1 \mathrm{Sim}$
$\rightarrow$ Sec. $M$

XL28- Quando foi a primeira vez que você pegou um teste positivo de Hepatite C? 


\section{SEÇÃO M: UTILIZAÇÃO DE SERVIÇOS}

QM01- Qual foi a última vez que você recebeu algum serviço médico? Quero dizer, sobre serviços com intenção de ajudar você quando esteve doente, ou para checar sua saude. Não incluindo serviços de tratamento de drogas. (Não leia as opções. Circule uma resposta)

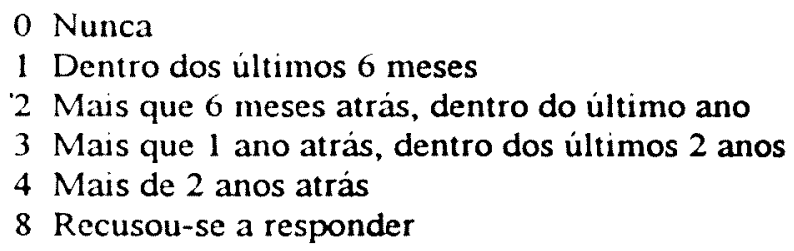

QM02- Você geralmente tem dificuldade em obter um tratamento médico se está doente?
0 Não
1 Sim
8 Recusou-se a responder $\rightarrow$ QM 04
$\rightarrow$ QM 04

QM03- Por que você não pode obter um tratamento médico se você precisa?

(Não leia a lista. Circule mais de um "sin"" se mencionado .Pergunte "algo mais ?")

01 Não existente o serviço

02 Não tem serviço próximo

03 Sem jeito de chegar lá

04 Não está sempre aberto/horários inconvenientes

05 Eles falam outro idioma

06 Não gosta/confia/ou acredita em médicos

Mencionado

07 Nào pode pagar o tratamento disponivel

Não Sim

08 Tratamento disponivel, mas não podem me ajudar, não no que necessito

0

0

0

0

0

0

Tratamento disponivel, mas não estou satisfeito com o critério de admissão no serviço

10 Medo dos procedimentos penosos do tratamento

11 Medo da interferência ou de ser preso pelas autoridades

12 Os locais do tratamento são muito hostis com os usuários de drogas

13 Os locais do tratamento não aceitam usuários de drogas

91 Outros (__ especificar

92 Outros (_ especificar

$\begin{array}{ll}0 & 1 \\ 0 & 1 \\ 0 & 1 \\ 0 & 1 \\ & \\ 0 & 1 \\ 0 & 1 \\ 0 & 1 \\ 0 & 1\end{array}$

QM04- Você geralmente tem dificuldade em obter tratamento de drogas, se você precisar?
0 Não
$\rightarrow$ QM 06
$1 \mathrm{Sim}$
8 Recusou-se a responder $\rightarrow$ QM 06 
QM05- Por que é dificil conseguir tratamento de drogas?

(Não leia a lista. Circule mais de um "sim". Estimule somente com "algo mais")?

01 Não existe esse tipo de serviço na cidade

02 Nào tem serviço próximo de onde eu moro

03 Fico sem jeito de chegar lá

04 Não está sempre aberto/horário inconveniente

05 Falam outro idioma

06 Não gosta/confia/acredita nesses serviços

07 Não pode pagar o tratamento disponivel

08 Tratamento disponivel, mas não podem ajudar, não no que necessito

09 Tratamento disponivel, mas não estou satisfeito com o critério de admissão

10 Medo dos procedimentos penosos do tratamento

11 Medo da interferência ou prisão pelas autoridades

12 Tem orientação religiosa e eu não gosto

13 Todos exigem abstinência

91 Outros especificar

92 Outros especificar

$\begin{array}{cc}\text { Não } & \text { Sim } \\ 0 & 1 \\ 0 & 1 \\ 0 & 1 \\ 0 & 1 \\ 0 & 1 \\ 0 & 1 \\ 0 & 1 \\ & \\ 0 & 1 \\ & \\ 0 & 1 \\ 0 & 1 \\ 0 & 1 \\ 0 & 1 \\ 0 & 1 \\ 0 & 1 \\ 0 & 1\end{array}$

QM06- Houve algum médico, serviços de prevenção de HIV, serviços relacionados à drogas outros serviços, que você não quis utilizar, porque estava receoso da policia ou outras autoridades?
0 Não
$\rightarrow \operatorname{Sec} . \mathrm{N}$
1 Sim
8 Recusou-se a responder $\rightarrow$ Sec. $N$

QM07- Quais foram esses serviços?

(Não leia a lista. Circule mais de um "sim" se mencionado. Pergunte somente "algo mais")?

01 Todos os serviços, porque eu não queria que as autoridades soubessem de mim

02 Tratamento medico relacionado com AIDS

03 Tratamento médico relacionado com Hepatite

04 Tratamento médico relacionado com DST

05 Tratamento para overdose

06 Tratamento de drogas

07 Programa de Troca de Agulhas/Seringas

08 Tratamento contra Trauma de Violência

09 Tratamento Médico Geral

10 Tratamento Psiquiatrico

11 Pronto Socorro

91 Outros ) especificar

92 Outros ) especificar

\begin{tabular}{|c|c|}
\hline Não & \\
\hline$n$ & \\
\hline 0 & \\
\hline 0 & \\
\hline 0 & \\
\hline 0 & \\
\hline 0 & \\
\hline 0 & \\
\hline 0 & \\
\hline 0 & \\
\hline 0 & \\
\hline 0 & \\
\hline 0 & \\
\hline 0 & \\
\hline
\end{tabular}




\section{SEÇÃO N: OVERDOSE}

QNO1 - Vocé jả presenciou quando outra pessoa entrou em overdose a ponto de perder a consciência?
0 Nào
$\rightarrow$ QN 05
1 Sim
8 Recusou-se a responder $\rightarrow$ QN 05

QN02- Quantas vezes isso aconteceu?

\section{MOSTRARO ( ARTAOD}
1- 1 vez
4- 6-10 vezes
2- 2 vezes
5- mais de 10 vezes
3- $3-5$ vezes
8- Sem resposta

QN03- Por favor, pense sobre a ultima vez que aconteceu. Quanto tempo atrás isso ocorreu? (Nào leia as opçòes. Circule uma resposta)

1 Dentro da ultima semana

2 Mais de 1 semana atrás, mas dentro do último mês

3 Mais que 1 més atrás dentro dos últimos 6 meses

4 Mais que 6 meses atrás, dentro do último ano

5 Mais que $\mathbf{i}$ ano atrás, dentro dos últimos 2 anos (mais ou menos 1 )

6 Mais que 2 anos atrás, dentro dos 5 anos

7 Mais que 5 anos atrás

8 Recusou-se a responder

QN04- O que você e as outras pessoas fizeram?

( Não leia a lista. Circule mais de um "sim" se mencionado. Pergunte somente "algo mais")?

01 Nada

02 Nào sabia o que fazer

03 DFA UMA JUCTA EA PCIOA

04 Colocou a pessoa em posição "abrir a respiração"

05 Respiração boca-a-boca

0o Aplicou Ressuscitação Cardio Pulmonar

07 Bateu/Esbofeteou/Beliscou a pessoa

08 Usou gelo, agua fria, gritou

09 Injetou outra droga (Ex.:Narcan, Nalox, Naltrexone e outros)

10 Injetou outra substáncia ( Ex:: sal, leite)

11 Usou outros remédios caseiros

12 Levou a pessoa ao hospital

13 Chamou ambulância

14 Piocurou ajuda de uma pessoa da lei

15 Informou aos parentes

16 Deixou o local imediatamente

17 Outros ) especificar

18 Outros ) especificar

$\begin{array}{cc}\text { Não } & \text { Sim } \\ 0 & 1 \\ 0 & 1 \\ 0 & 1 \\ 0 & 1 \\ 0 & 1 \\ 0 & 1 \\ 0 & 1 \\ 0 & 1 \\ 0 & 1 \\ 0 & 1 \\ 0 & 1 \\ 0 & 1 \\ 0 & 1 \\ 0 & 1 \\ 0 & 1 \\ 0 & 1 \\ 0 & 1 \\ 0 & 1\end{array}$


QN05- Você conhece alguem que tenha morrido de overdose? Quantas pessoas?

(Não leia as opções. Circule uma resposta)

0 Nenhuma

1 Um

2 Dois

$33-5$

46 ou mais

8 Recusou-se a responder

XNO6- Você já teve uma overdose a ponto de perder a consciência?
0 Não
$\rightarrow \mathrm{XN} 14$
1 Sim
8 Recusou-se a responder $\rightarrow$ XN 14

XN07- Quantas vezes isso aconteceu?

MOSTRARO CARTATOD

1- $1 \mathrm{Vez}$

2- 2 vezes

$3-3-5$ Vezes

4- 6 - 10 Vezes

5- Mais de 10 Vezes

XN08- Por favor, pense sobre a última vez que isso aconteceu. Há quanto tempo atrás isso aconteceu?

(Não leia as opções. Circule uma resposta)

1 Semana passada

2 Mais de 1 semana atrás, dentro do último mês

3 Mais de 1 mês atrás, dentro dos últimos 6 meses

4 Mais de 6 meses atrás dentro do último ano

5 Mais de 1 ano atrás, dentro dos últimos 2 anos

6 Mais de 2 anos atrás, dentro dos últimos 5 anos

7 Mais de 5 anos atrás

8 Recusou-se a responder

XNO9- Você estava sozinho no momento?
0 Não
$1 \mathrm{Sim}$
8 Recusou-se a responder

XN10- Você recebeu ajuda de alguém depois da última vez que você teve overdose?
0 Nào
$\rightarrow \mathrm{XN} 12$
$1 \mathrm{Sim}$
8 Recusou-se a responder
$\rightarrow \mathrm{XN} 12$ 
XNII- Quem ajudou voce?

(Naio lela a lista Circule maus de um "sim" se mencionado. Pergunte somente "alguém mas")?

01 Parcerro (s) sexual usuario (s) de drogas

02 Pancutes (s) usuario (s) de drogas (não sexual)

(1) Amm:o (s) usuario (s) de drogas

04 Outro (s) usuano (s) de drogas

05 Parceno sexual nào usuario de drogas

11. Parente (s) (Não parceiro sexual), não usuáno de drogas

07 Amigo (s) não usuario de drogas

us Pessoa da let

104 Traficantedistribuidor de drogas

10 Outros estranhos

11 Pessoas desconhecidas (enquanto estava inconsciente)

12 Profissional da Saude

13 Outros( $)$ especificar
if Outrose especificar

$\begin{array}{cc}\text { Não } & \text { Sım } \\ 0 & 1 \\ 0 & 1 \\ 0 & 1 \\ 0 & 1 \\ 0 & 1 \\ 0 & 1 \\ 0 & 1 \\ 0 & 1 \\ 0 & 1 \\ 0 & 1 \\ 0 & 1 \\ 0 & 1 \\ 0 & 1 \\ 0 & 1\end{array}$

XN12- Teve alg̣ucm presente que não ajudou vocë depois da última overdose?
(1) Nao
$\rightarrow \mathrm{XN} 14$
1 Sim
8 Recusou-se a responder
$\rightarrow \mathrm{XN} 14$

XNI Y- Mu:m estara presente e não ajudou vocé?

01 Parcenro (s) sevual usuano de drogas

02 Patente (s) usuario de drogas (não sexual)

o) Ammgo (s) usuarios de drogas

14. Ontro (s) usuario de drogas

(15) Patceno sexual não usuario de drogas

(x) Patcme não usuatro de drogas ( nào parceiro sexual)

(1) Antugo $(5)$ não usuat to de drogas

us Pessoa da ler

(u) Traficante

It) Outros estranhos

11 Pessoas desconhecidas (enquanto estava inconsciente)

12 Ontios ) especificar

13 Uutios ( especificar

$\begin{array}{cc}\text { Nảo } & \text { Sım } \\ 0 & 1 \\ 0 & 1 \\ 0 & 1 \\ 0 & 1 \\ 0 & 1 \\ 0 & 1 \\ 0 & 1 \\ 0 & 1 \\ 0 & 1 \\ 0 & 1 \\ 0 & 1 \\ 0 & 1 \\ 0 & 1\end{array}$

XNIt- Se voce fosse procurar ajuda médica por overdose, vocé acredita que poderia ser bem matado e por pessoas com experiéncia para ajuda-lo?
() Nio
I Sim
8 Recusou-se a responder

Wis- Se ace rocre procurar ajuda medica por overdose, vocè acredita que poderia ser demumctulo as antondades da lea?
(1) ino
1 Sm
s Reonsulse a responder

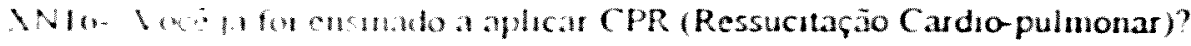

$$
\begin{aligned}
& \text { 1) Nio } \\
& \text { I Sinl } \\
& \text { s Recurousea tesponder }
\end{aligned}
$$


QN17- Você ja esteve presente, quando outra pessoa tomou muito estmmulante/alucinogeno ou outra droga e teve uma má reação intensa ( desmano, tontura ou crise de loucura)?
() Não - XN 21
I $\operatorname{Sin}$
8 Recusou-se a responder - XN 21

QN18- Quantas vezes isso aconteceu?

$$
\text { MOSTRHROCARTAOO }
$$
1- 1 vez
3- 3 - 5 vezes
5- Mais de 10 vezes
2- 2 Vezes
4- $6-10$ vezes

QN19- Por favor, pense sobre a última vez que aconteceu. Quanto tempo atrás isso aconteceu ? (Não leia as opçōes. Circule uma resposta)

1 Sellana passada

2 Mais que 1 semana atrás, dentro do mês passado anos

3 Mais que 1 mes atras, dentro dos últimos 6 meses

4 Mais que o meses atras, dentro do ultimo ano
5 Mais que 1 ano atrás, dentro dos últimos 2 anos 6 Mais que 2 anos atrás, dentro dos últimos 5

7 Mais que 5 anos atrás

8 Recusou-se a responder

QN20- O que vocé e os outros presentes fizeram?

(Não leia a lista. Circule mais de um "sim" se mencionado. Pergunte "algo mais"?)

(1) Nada

02 Não sabia o que fazer

103 DU I I A UOxTA CA PasuA

(1) Colocou a pessoa em posição "abrir a respiração "

05 Respiração boca-a-boca

60 Aplicou ressuscitação cardio- pulmonar

(17 Levou a pessoa para um quarto escuro ou quieto, ou para um ambiente familiar

08 Injetou heroina ou outra coisa

09 Deu para a pessoa álcool ou outro sedativo

10) Usou outro remédio caseiro

11 Levou a pessoa para o hospital/Posto de saude

12 Chamou una ambulância ou médico

13 Buscou ajuda em autoridades da lei

It Avisou aos familiares

15 Derxou o lugar imediatamente

16 Outros

17 Oulios

$\begin{array}{cc}\text { Não } & \text { Sim } \\ 0 & 1 \\ 0 & 1 \\ 0 & 1 \\ 0 & 1 \\ 0 & 1 \\ 0 & 1 \\ & \\ 0 & 1 \\ 0 & 1 \\ 0 & 1 \\ 0 & 1 \\ 0 & 1 \\ 0 & 1 \\ 0 & 1 \\ 0 & 1 \\ 0 & 1 \\ 0 & 1 \\ 0 & 1\end{array}$

XN21 - Você ja tomou muito estimulante/alucinógeno ou outra droga que causou uma má reação intensa (desmaio, tontura ou crise de loucura)?
0 Näo-Sec 0
$1 \mathrm{Sim}$
8 Recusou-se a responder - Sec. 0

XN22- Quamas vezes isso aconteceu? MIOSTRAR O CARTÃOD
1. 1 Ver
3 - 3 - 5 vezes
5- Mais de 10 vezes
2- 2 Vezes
4- 6 - 10 vezes
8- Recusou-se a responder 
XN23- Por favor, pense sobre a última vez que isso aconteceu. Quanto tempo atrás ocorreu?

1 Semana passada

2 Mais de 1 semana atrás, dentro do último 6 meses

3 Mais de 1 mês atrás dentro do último 6 meses

4 Mais de 6 meses atrás, dentro do último ano

5 Mais de 1 ano atrás, dentro dos últimos 2 anos

6 Mais de 2 anos atrás, dentro dos últimos 5 anos

7 Mais de 5 anos atrás

8 Recusou-se a responder

XN24- Você estava sozinho (a) no momento?

0 Não

1 Sim

8 Recusou-se a responder

XN25- Você recebeu ajuda de alguém depois da última vez que você teve uma má reação (desmaio, tontura ou crise de loucura)?
0 Nào
$\rightarrow \mathrm{XN} 27$
$1 \mathrm{Sim}$
8 Recusou-se a responder
$\rightarrow \quad \mathrm{XN} 27$

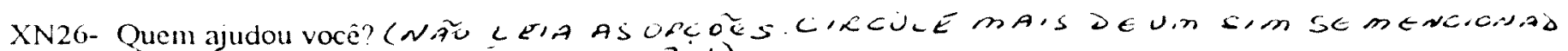
PECUUTE "ALGUGM m.P.s?"

01 Parceiro sexual usuário de drogas

02 Parente (s) usuário de drogas (não sexual)

03 Amigo (s) usuario de drogas

04 Outro (s) usuário de drogas

05 Parceiro sexual não usuário de drogas

06 Parente (s) não usuário de drogas (não sexual)

07 Amigo (s) não usuário de drogas

08 Pessoa da lei

09 Traficante

10 Outros estranhos

11 Pessoas desconhecidas (estava muito perturbado $\mathrm{p} / \mathrm{ver}$ )

12 Outro ) especificar

13 Outrol especificar

$\begin{array}{cc}\text { Não } & \text { Sim } \\ 0 & 1 \\ 0 & 1 \\ \text { u } & 1 \\ 0 & 1 \\ 0 & 1 \\ 0 & 1 \\ 0 & 1 \\ 0 & 1 \\ 0 & 1 \\ 0 & 1 \\ 0 & 1 \\ 0 & 1 \\ 0 & 1\end{array}$

XN27- Tinha alguém presente que não ajudou você depois da última vez que teve uma reação intensa (desmaio, tontura ou crise de loucura)?
0 Não
$\rightarrow$ Sec. O
1 Sim
8 Recusou-se a responder ou Sec. P
$\rightarrow \quad$ Sec. O
ou Sec. P 
XN28- Quem estava presente e não ajudou você?

(Não leia a lista. Circule mais de um "sim" se mencionado. Pergunte "alguém mais")?

01 Parceiro sexual usuário de drogas

02 Parente ( $\mathrm{s}$ ) usuário de drogas (não sexual)

03 Amigo (s) usuário de drogas

04 Outro (s) usuario de drogas

05 Parceiro sexual não usuário de drogas

06 Parente (s) não usuário de drogas, não parceiro sexual

07 Amigos não usuario de drogas

08 Pessoa da lei

09 Traficante

10 Outros estranhos

11 Pessoas desconhecidas (estava muito perturbado $\mathrm{p} / \mathrm{ver}$ )

12 Outros ) especificar

13 Outros ) especificar

$\begin{array}{cc}\text { Não } & \text { Sim } \\ 0 & 1 \\ 0 & 1 \\ 0 & 1 \\ 0 & 1 \\ 0 & 1 \\ 0 & 1 \\ 0 & 1 \\ 0 & 1 \\ 0 & 1 \\ 0 & 1 \\ 0 & 1 \\ 0 & 1 \\ 0 & 1\end{array}$




\title{
SEÇĀO O: VIOLÊNCIA
}

(MODULO OPCIONAL LOCAL)

Muıtas pessoas são vitimas de violência em algum ponto de suas vidas. Isso é mais comum para pessoas que usam drogas. Pense, desde o começo que vocè começou a usar drogas. Vou perguntar sobre suas experiéncias durante esse tempo

XO01- Qual dessas opçōes descreve melhor, a frequencia em que você foi esmurrado, chutado ou batido?

\section{MOSTRAR O CARTÃO E}

1- Nunca D 2000

2- 1 ou 2 vezes

3- Poucas vezes

4- I vez por ano

5- I vez por més

6- I vez por semana

7- Muitas vezes para manter-se a par

XO02- De seu conhecimento, quantas vezes isso foi feito por usuários de drogas que estavam engajados em negocios de venda ou uso de drogas?

\section{MOSTRAR O CARTÃO E}

1- Nunca

2- 1 ou 2 vezes

3- Poucas vezes

4- 1 vez por ano

5- 1 vez por mês

6- I vez por semana

7. Muitas vezes para manter-se a par

XO03-- De seu conhecimento, quantas vezes isso foi feito por não usuários de drogas que estavam engajados em negocios de venda ou uso de drogas?

\section{MOSTRAR O CARTÃOE}

1- Nunca

2- 1 ou 2 vezes

3- Poucas vezes

4- I vez por ano

5- I vez por mês

6- 1 vez por semana

7- Muitas vezes para manter-se a par

XO04 - Quantas vezes isso foi feito por vizinhos ou pessoas da vizinhança?

\author{
MOSTRAR O CARTÃOE \\ 1- Nunca \\ 2- 1 ou 2 vezes \\ 3- Poucas vezes \\ 4. 1 vez por ano \\ 5- 1 vez por mes \\ 6- I vez por semana \\ 7- Multas vezes para manter-se a par
}


XO05- Quantas vezes isso foi feito por policiais, soldados ou outros oficiais?

\section{MOSTRAR O CARTÃO E}

1. Nunca

2- 1 ou 2 vezes

3- Poucas vezes

4- 1 vez por ano

5- 1 vez por mês

6- 1 vez por semana

7- Muitas vezes para manter-se a par

XO06- Qual dessas opções descreve melhor a frequencia, que você foi atacado por uma arma?

\section{MOSTRAR O CARTÃOE}

1- Nunca

2- 1 ou 2 vezes

3- Poucas vezes

4- 1 vez por ano

5- 1 vez por mês

o- 1 vez por semana

7. Muitas vezes para manter-se a par

Se a resposta for "nunca" para XO 01 e XO 06, pular para XO $13 \rightarrow$ XO 13 . Se somente XO 06 for "nunca" pular para XO $11 \rightarrow$ XO 11.

XO07-- De seu conhecimento, quantas vezes isso foi feito por outros usuários de drogas que estavam engajados em negocios de venda ou uso de drogas?

\section{MOSTRAR O CARTÃO E}

1- Nunca

2- 1 ou 2 vezes

3- Poucas vezes

4- 1 vez por ano

5- 1 vez por més

0- 1 vez por semana

7- Muitas vezes para manter-se a par

XO08- De seu conhecimento, quantas vezes isso foi feito por não usuários de drogas que estavam engajados em negocios de venda ou uso de drogas?

\section{MOSTRAR O CARTÃo E}

1- Nunca

2- 1 ou 2 vezes

3- Poucas vezes

4- 1 vez por ano

5- I vez por més

(6- I vez por semana

7- Muitas vezes para manter-se a par 
XO09- Quantas vezes isso aconteceu por pessoas da vizinhaça ou vizinhos?

\section{MOSTRAR O CARTÃO E}

1- Nunca

2- 1 ou 2 vezes

3- Poucas vezes

4- 1 vez por ano

5- 1 vez por mês

6- 1 vez por semana

7- Muitas vezes para manter-se a par

XO10- Quantas vezes isso foi feito por policiais, soldados ou outros oficiais?

\section{MOSTRAR O CARTÃO E}

1- Nunca

2- 1 ou 2 vezes

3- Poucas vezes

4- 1 vez por ano

5- 1 vez por mès

6- 1 vez por semana

7- Muitas vezes para manter-se a par

XO 11 - Você recebeu algum cuidado médico como resultado de alguém ter batido ou qualquer outro ataque, desde que você começou a usar drogas?
0 Não
$\rightarrow \mathrm{XO} 13$
$1 \mathrm{Sim}$
8 Recusou-se a responder $\rightarrow$ XO 13

XO 12 -- Quantas vezes?

\section{MOSTRAR O CARTÃO E}

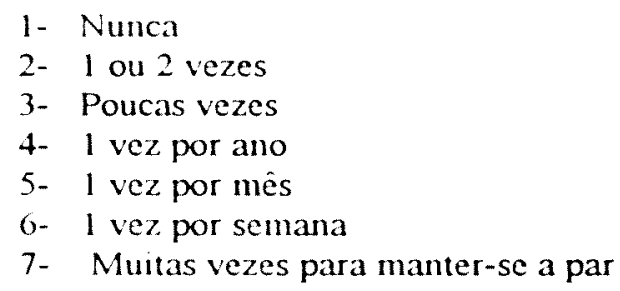

XO 13 - Você geralmente tem acesso a um tratamento médico, se você precisar como resultado de algum ataque violento?
O Não
$1 \mathrm{Sim} \quad \rightarrow \mathrm{XO} 15$
8 Recusou-se a responder $\rightarrow$ XO 15 
XO 14 - Porque você não pode ter acesso a um tratamento médico, se precisar?

01 Sem serviço existente

02 Sem serviço próximo

03 Sem jeito de chegar

04 Não está sempre aberto/Horário inconveniente

05 Falam outro idioma

06 Não gosta/acredita/confia em médicos

07 Tratamento disponivel, mas não posso pagar

08 O tratamento não aceita usuário de drogas

09 Medo das autoridades

10 Outros (_ especificar

12 Outros $\longrightarrow$ especificar

\begin{tabular}{cc} 
Nomeionado & $\leq 1 \mathrm{~m}$ \\
\hdashline 0 & 1 \\
0 & 1 \\
0 & 1 \\
0 & 1 \\
0 & 1 \\
0 & 1 \\
0 & 1 \\
0 & 1 \\
0 & 1 \\
0 & 1 \\
0 & 1
\end{tabular}

XO15 - Durante o tempo em que tem usado drogas, quantas vezes você bateu ou atacou outras pessoas com uma arma?

\section{MOSTRAR O CARTÃO E}

1- Nunca

2- 1 ou 2 vezes

3- Poucas vezes

41 vez por ano

5- 1 vez por mès

6- 1 vez por semana

7- Muitas vezes para manter-se a par

\section{SEÇÃO P: CONCLUSÃO}

Agora, mais algamas nqestōes

QP01- Você se considera:

( Leia as opçôes- exceto Recusou-se a responder. Circule uma resposta)

1 Heterossexual

2 Gay ou homossexual (perguntar somente para homem)

3 Lésbica ou homossexual (perguntar somente para mulher)

4 Bissexual

8 Recusou-se a responder

QP02- Quantos fillos (as) biológicos você tem?

XP03- Você planeja ter (outroffilho?
0 Não
1 Sim
2 Estou gravida parceira está
3 Recusou-se a responder
4 Não sabe 
XP04 Pense nos próximos doze meses. Você espera alguma mudança nos seguintes itens:

Não Sim Rec.

1 Seu modo de administrar as drogas

$0 \quad 1$

2 Seu nivel de consumo da droga

3 Seu emprego

4 Sua principal fonte de renda

5 Sua saúde

$\begin{array}{lll}0 & 1 & 8 \\ 0 & 1 & 8 \\ 0 & 1 & 8 \\ 0 & 1 & 8\end{array}$

\section{PARA CLASSIFICAÇÃO DO ENTREVISTADOR}

$\begin{array}{ll}\text { UDI } & (\quad) \\ \text { EX } & (\quad)\end{array}$

